MARIANNA SILVA DIAS

ANÁLISE DO COMPORTAMENTO DE EDIFÍCIOS APOIADOS EM FUNDAÇÃO DIRETA NO BAIRRO DA PONTA DA PRAIA NA CIDADE DE SANTOS

São Paulo

2010 
Este exemplar foi revisado e alterado em relação à versão original, sob responsabilidade única do autor e com a anuência de seu orientador.

São Paulo, de junho de 2010.

Assinatura do autor

Assinatura do orientador

FICHA CATALOGRÁFICA

Dias, Marianna Silva

Análise do comportamento de edifícios apoiados em fundação direta no bairro da Ponta da Praia na cidade de Santos /

M.S. Dias. -- ed.rev. -- São Paulo, 2010.

$145 \mathrm{p}$.

Dissertação (Mestrado) - Escola Politécnica da Universidade de São Paulo. Departamento de Engenharia de Estruturas e Geotécnica.

1.Fundações (Engenharia) - Santos (SP) I.Universidade de São Paulo. Escola Politécnica. Departamento de Engenharia de Estruturas e Geotécnica II.t. 
MARIANNA SILVA DIAS

\section{ANÁLISE DO COMPORTAMENTO DE EDIFÍCIOS APOIADOS EM FUNDAÇÃO DIRETA NO BAIRRO DA PONTA DA PRAIA NA CIDADE DE SANTOS}

Dissertação apresentada à Escola Politécnica da Universidade de São Paulo para obtenção do Título de Mestre em Engenharia

Área de Concentração: Engenharia Geotécnica

Orientador: Prof. Dr. Faiçal Massad

São Paulo 


\section{AGRADECIMENTOS}

Aos meus pais pelo constante apoio, carinho e motivação que me deram ao longo de todos os anos de estudo.

Ao meu noivo, pela compreensão, paciência e incentivo.

Ao Prof. Dr. Faiçal Massad pela atenção e ensinamentos durante todo o processo de definição e orientação.

À Zaclis Falconi e a todos os meus companheiros de trabalho que de alguma forma contribuíram para a conclusão desse trabalho

À Engesolos por disponibilizar seus arquivos e contribuir com a pesquisa 
"O novo não está nas coisas. Está na maneira como você olha para elas" 


\section{ÍNDICE}

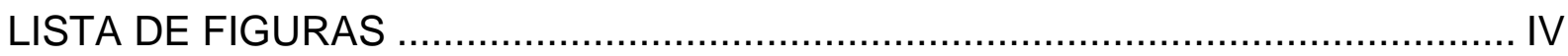

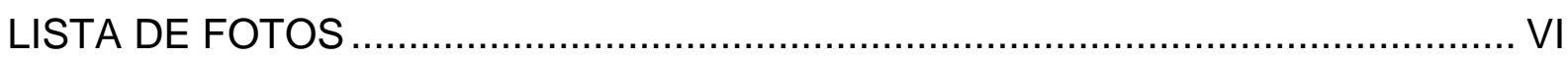

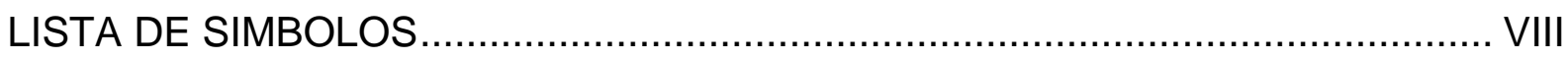

RESUMO

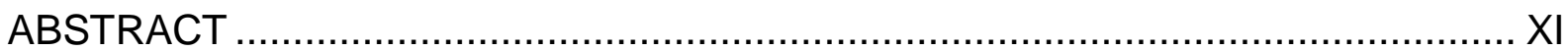

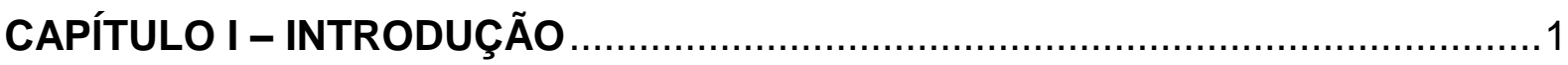

1.1 - O PROBLEMA DAS FUNDAÇÕES EM SANTOS ......................................1

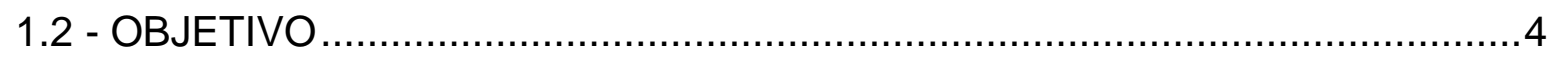

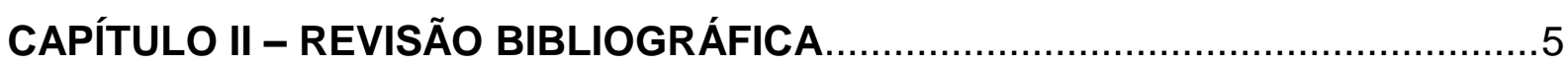

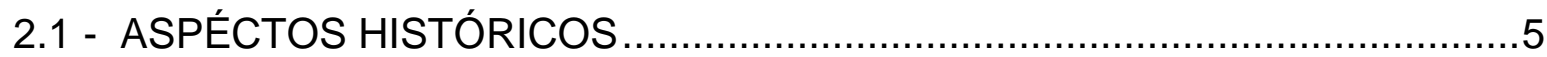

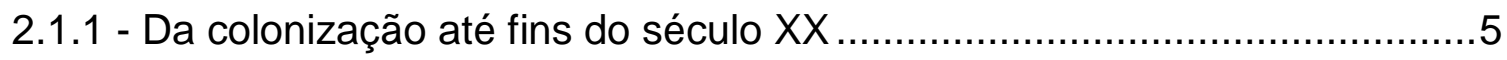

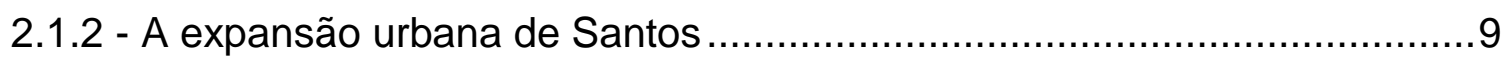

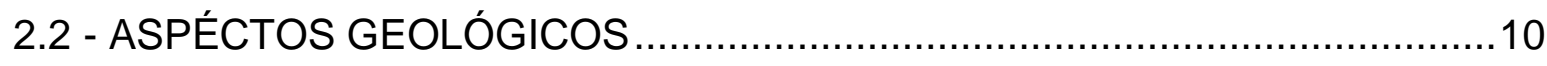

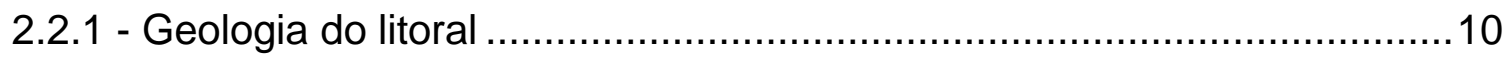

2.2.2 - Influência das elevações do nível do mar na Baixada Santista ..............12

2.2.3 - Planícies sedimentares quaternárias de São Paulo ...............................13

2.2.4 - As ilhas barreiras e os sedimentos flúvio lagunares .............................15

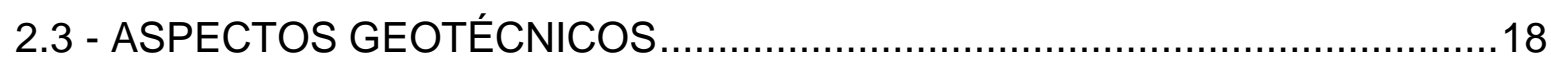

2.3.1 - Pressão de pré - adensamento e origem do sobreadensamento ............18

2.3.2 - Propriedades geotécnicas dos sedimentos da Baixada Santista ............19

2.3.3 - Perfil geotécnico da cidade de Santos .............................................21

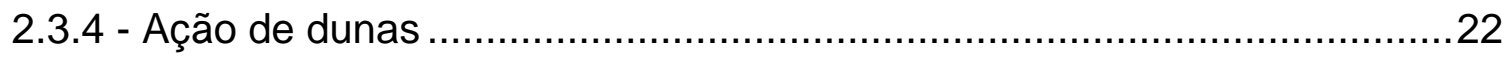

2.3.5 - Influência das dunas nos recalques dos edifícios .................................25

2.4 - OS RECALQUES E AS FUNDAÇÕES DOS EDIFÍCIOS ............................26

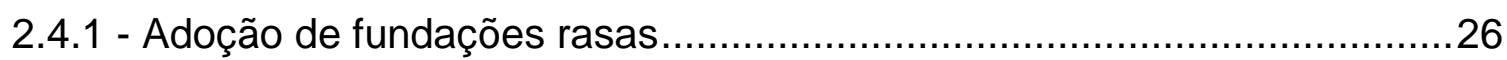

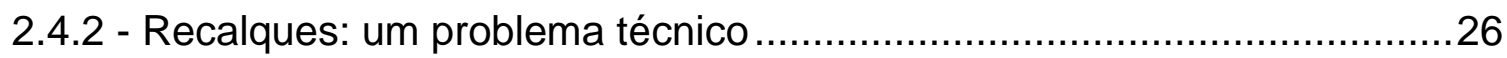

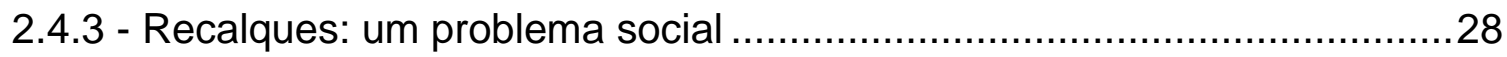

2.4.4 - O uso atual de fundações profundas ...............................................29

2.5 - TÉCNICAS DESENVOLVIDAS PARA A ESTABILIZAÇÃO DOS

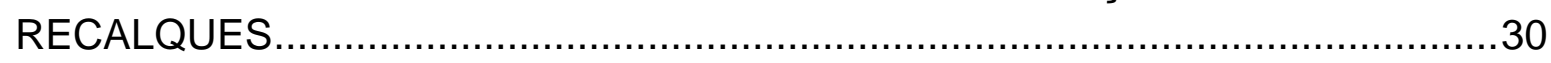

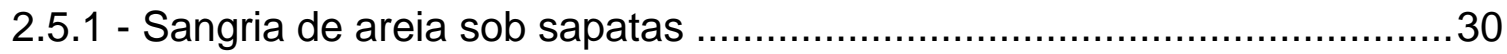

2.5.2 - Carregamento do lado menos recalcado ……….................................. 
2.5.3 - Injeções para expandir o solo .32

2.5.4 - Sistema cisalhante de Ranzini .33

2.5.5 - Reforço da fundação com emprego de estacas profundas .34

a) O caso do edifício Núncio Malzoni .35

b) $O$ caso do edifício Excelsior 37

c) O caso do edifício Morená 38

2.5.6 - Deformações controladas através da extração de solo mole. .39

2.5.7 - Síntese dos métodos de estabilização de recalques apresentados. 41

CAPÍTULO III - PROJETO ORLA E A PONTA DA PRAIA 43

3.1 - O PROJETO ORLA .43

3.1.1 - Área de estudo. .43

3.1.2 - Digitalização e elaboração de mapas .44

3.2 - PONTA DA PRAIA. .52

3.2.1 - Características e localização .52

3.2.2 - Levantamento de dados na Prefeitura Municipal de Santos .55

CAPÍTULO IV - INTERPRETAÇÃO DE ENSAIOS E PREVISÃO DE RECALQUES NA CIDADE DE SANTOS.

4.1 - ANÁLISE COMPARATIVA DE SONDAGENS DE SIMPLES RECONHECIMENTO, COM MEDIDAS DE N .63

4.1.1 - Sondagens coletadas e analisadas. .63

4.1.2 - Valores de $\mathrm{N}_{\text {spt médio }}$ para as sondagens de referência. .66

4.1.3 - Análise das sondagens ... .69

4.2 - SONDAGENS PROFUNDAS .69

4.3 - RESULTADOS DE ENSAIOS DO CONE (CPT e CPTU) NA CIDADE DE SANTOS. 73

4.3.1 - Ensaios analisados .73

4.3.2 - Parâmetros geotécnicos obtidos através dos ensaios do cone .78

4.3.2.1 - Densidade relativa e ângulo de atrito interno .81

4.3.2.1 - Módulo de deformabilidade. .82

4.3.3 - Análise dos resultados .84

4.4 - PREVISÃO DE RECALQUES .86

4.4.1 - Cálculos para a região da "Faixa Crítica" e Ponta da Praia; edifício com 16 pavimentos (edifício "A") .86

4.4.2 - Cálculos para a região da "Faixa Crítica" e Ponta da Praia - edifício com 12 pavimentos (edifício "B") 


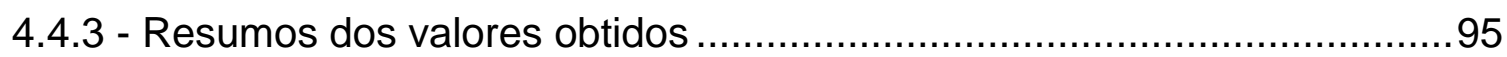

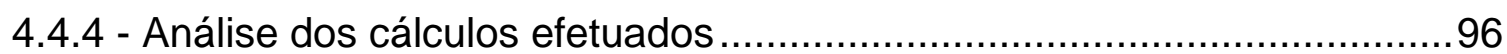

4.5 - READAPTAÇÃO DA SEÇÃO GEOTÉCNICA DA ORLA DE SANTOS .........97

4.5.1 - Destaque a orla do bairro da Ponta da Praia e seção transversal à praia. .97

4.5.2 - Seções transversais a orla de Santos................................................99

4.5.3 - Análise das seções transversais ................................................... 104

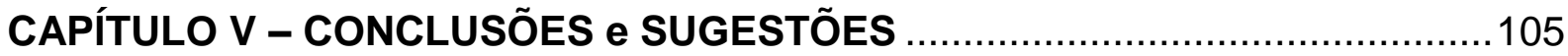

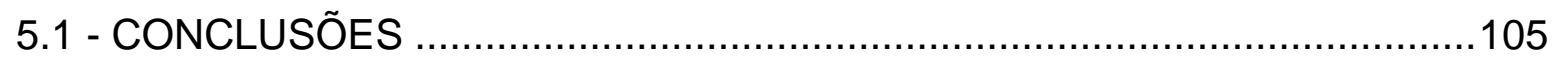

5.2 - SUGESTÕES PARA CONTINUIDADE DA PESQUISA ..........................106 ANEXO A - SONDAGENS DE REFERÊNCIA BAIRRO BOQUEIRÃO (canal 3 -

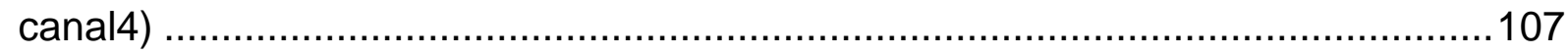

ANEXO B - SONDAGENS DE REFERÊNCIA BAIRRO EMBARÉ (canal 4 - canal 5) 113

ANEXO C - SONDAGENS DE REFERÊNCIA BAIRRO APARECIDA (canal 5 - canal 6) 118

ANEXO D - SONDAGENS DE REFERÊNCIA BAIRRO PONTA DA PRAIA (canal 6 Ferry Boat) 123

ANEXO E - SONDAGENS DE REFERÊNCIA SEÇÕES TRANSVERSAIS (Praia Centro) 131

BIBLIOGRAFIA. 144

BIBLIOGRAFIA COMPLEMENTAR. 150 


\section{LISTA DE FIGURAS}

Figura 01 - Perfil Geotécnico sintético da Orla Praiana ............................................

Figura 02 - Perfil Geotécnico sintético da orla praiana ...........................................

Figura 03 - Ilha de Santo Amaro .....................................................................

Figura 04 - Planícies Costeiras quaternárias do Litoral Paulista distribuídas em quatro compartimentos morfológicos ...............................................................11

Figura 05 - Esquema da Geologia da Baixada litorânea Santista. ..........................11

Figura 06 - Lençol freático na Baixada Santista ................................................12

Figura 07 - Curvas de variação do nível relativo do mar durante os últimos 7.500 anos no trecho compreendido entre Santos - Bertioga.

Figura 08 - llustração da formação das planíces quaternárias do Estado de São

Paulo. 15

Figura 09 - Ilustração da Formação da llhas Barreiras

Figura 10 - Esquema da construção de um edifício onde antes existia uma duna

Figura 11 -Locação dos pilares extremos do Palácios de Belas Artes .33

Figura 12 - Esquema representativo do método de Ranzini. 34

Figura 13 - Esquema representativo de como pode ser feita a extração de argila sob as sapatas 39

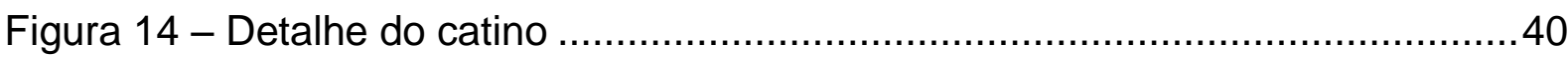

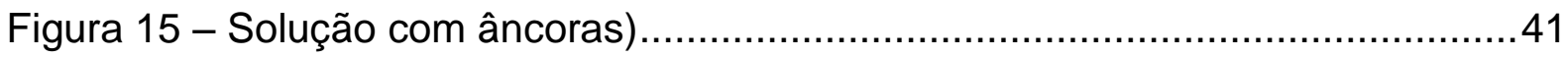

Figura 16 - Solução final - extração de solo......................................................... 42

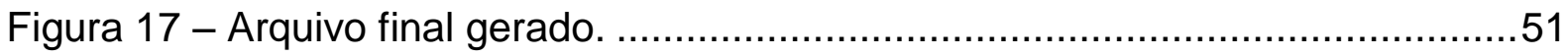

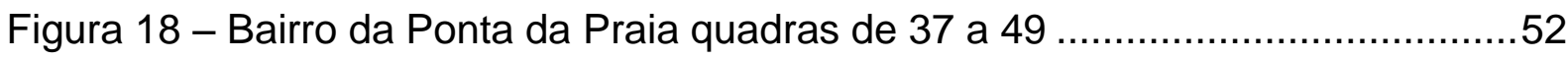

Figura 19 - Esquema de posicionamento dos edifícios da quadra 37 ....................59

Figura 20 - Esquema de posicionamento dos edifícios da quadra 38 ...................59

Figura 21 - Esquema de posicionamento dos edifícios da quadra 39 ....................60

Figura 22 - Esquema de posicionamento dos edifícios da quadra 40 .....................60

Figura 23 - Esquema de posicionamento dos edifícios da quadra 41 ......................61

Figura 24 - Esquema de posicionamento dos edifícios da quadra 42 .....................61

Figura 25 - Esquema de posicionamento dos edifícios da quadra 43 ......................62

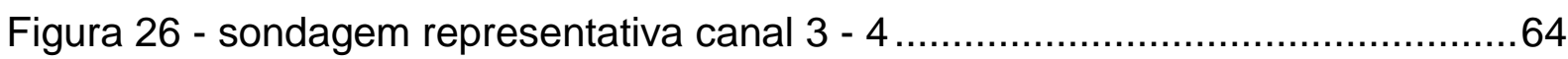


Figura 27 - sondagem representativa canal 4 - 5 .64

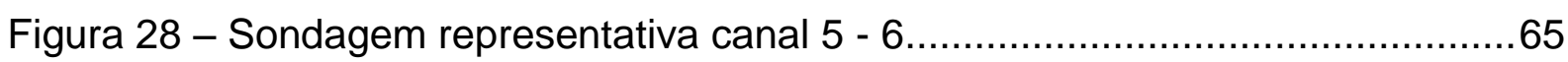

Figura 29 - Sondagem representativa Ponta da Praia............................................65

Figura 30 - Locação das sondagens e ensaios coletados ......................................66

Figura 31 - Sondagem representativa próxima ao canal 4 ..................................71

Figura 32 - Sondagem representativa próxima ao canal 6 .....................................

Figura 33 - Locação e resultados dos ensaios de CPTU - Edifíco Unisanta, próximo

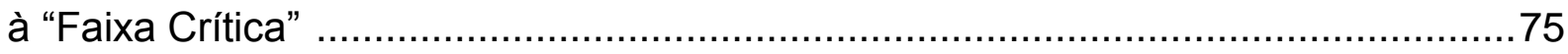

Figura 34 - Locação e resultados dos ensaios de CPT .........................................76

Figura 35 - Locação e resultados dos ensaios de CPT na Ponta da praia ...............77

Figura 36 - Gráfico resistência de ponta média $\left(q_{c}\right) \times N_{S P T}$, para os CPTs do bairro do Boqueirão.

Figura 37 - Gráfico resistência de ponta média $\left(q_{c}\right) \times N_{S P T}$, para os CPTs da Ponta

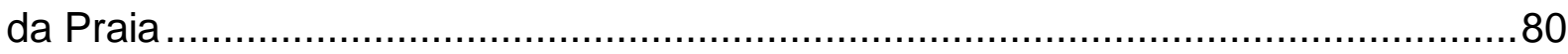

Figura 38 - Comparação entre qc e NSPT Sanglerat, 1972 .................................... 84

Figura 39 - Esquema de dissipação de cargas para o perfil adotado da "Faixa Crítica" edifíco "A", com 16 pavimentos

Figura 40 - Esquema de dissipação de cargas para o perfil adotado da Ponta da Praia edifício " $A$ ", com 16 pavimentos

Figura 41 - Esquema de dissipação de cargas para o perfil adotado da "Faixa Crítica" edifício "B", com 12 pavimentos.

Figura 42 - Esquema de dissipação de cargas para o perfil adotado da Ponta da Praia edifício "B", com 12 pavimentos

Figura 43 - Perfil Geotécnico sintético da orla praiana - Adaptado de Teixeira (1994) e Massad (2003).

Figura 44 - Representação do perfil geotécnico sintético da orla da Ponta da Praia e

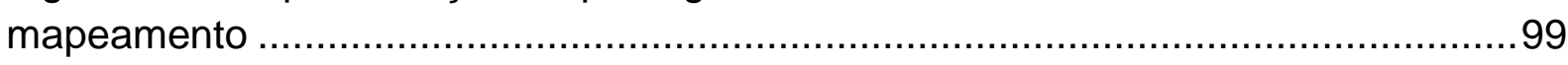

Figura 45 - Seção Transversal 1 sentido praia - centro (canal1)........................100

Figura 46 - Seção Transversal 2 sentido praia - centro (canal2) ..........................101

Figura 47 - Seção transversal 3 sentido praia - centro (canal 3) ..........................102

Figura 48 - Seção transversal 4 sentido praia - centro (canal 6) ...........................103

Figura 49 - Seção transversal 5 sentido praia - centro (canal 7) ..........................104 


\section{LISTA DE FOTOS}

Foto 01 - Foto aérea da cidade de Santos. Em destaque a "Faixa Crítica" e o bairro da Ponta da Praia.

Foto 02 - Santos em 1865.

Foto 03 - Porto de Santos próximo à Alfândega por volta de 1860 ainda com trapiches.

Foto 04 - Antiga duna existente na Ponta da Praia, início do Sec. XX ...................23

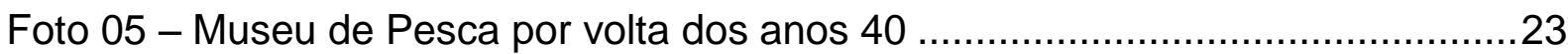

Foto 06 - Museu de Pesca hoje, após a restauração. ......................................24

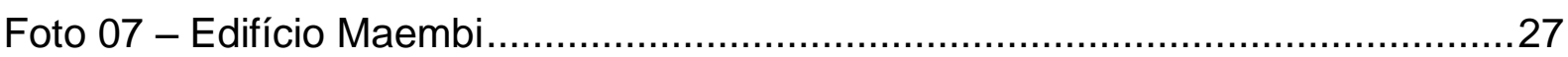

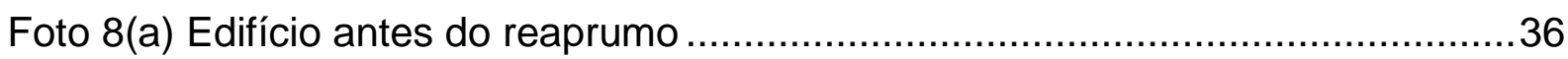

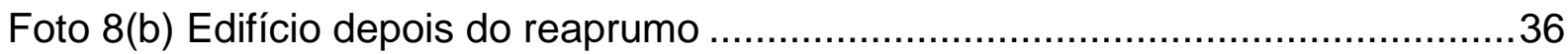

Foto 09 - Edifício Excelsior inclinado para o lado do canal 4 .................................37

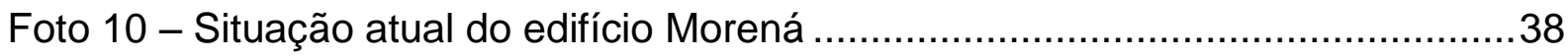

Foto 11 - Delimitação das 49 quadras ao longo de toda orla Santista ....................50

Foto 12 - Processo de digitalização das quadras - exemplo quadra 37 .................51

Foto 13 - Bairro da Ponta da Praia por volta dos anos 20 ou 30 ..........................53

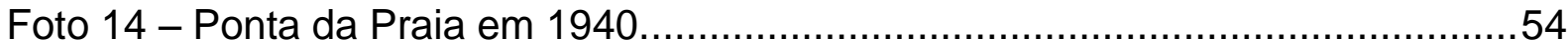

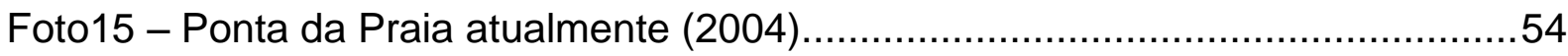

Foto 16 - Bairro da Ponta da Praia em duas vistas ............................................58

Foto 17 - Panorâmica 1 - Vista dos edifícios trecho mais densificado da Ponta da

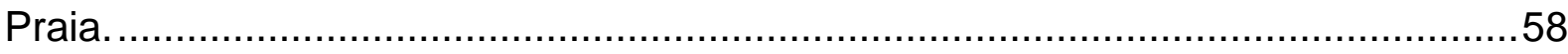

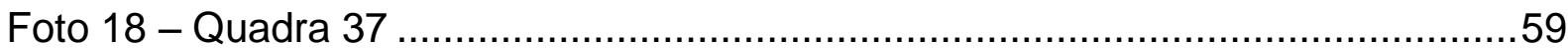

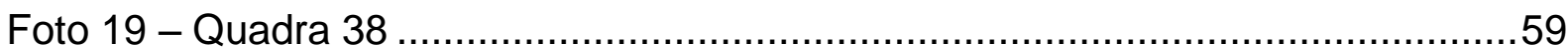

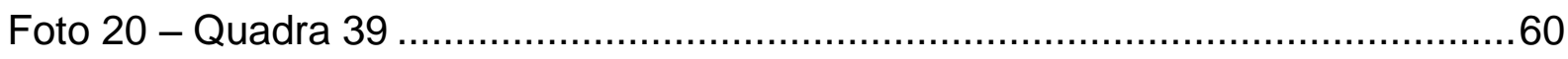

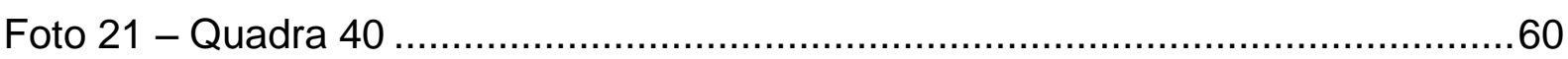

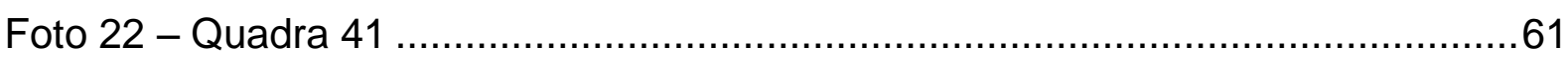

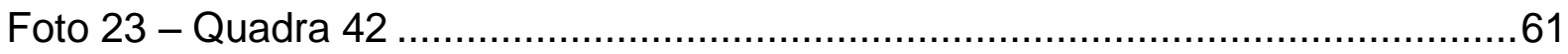

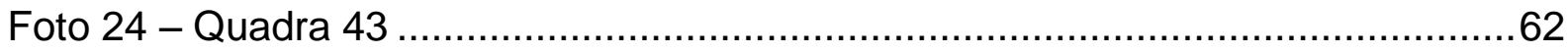

Foto 25 - Argila SFL aos 10m de profundidade ........................................... 72

Foto 26 - Argila A.T aos $42 m$ de profundidade ............................................. 72

Foto 27 - Argila avermelhada aos 56,0 m de profundidade .................................. 72

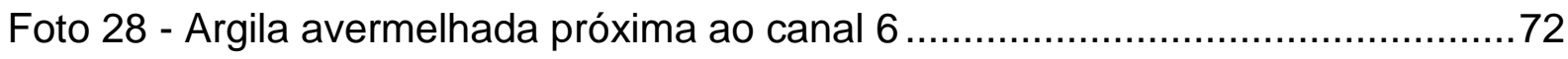




\section{LISTA DE TABELAS}

Tabela I - Parâmetros geotécnicos de Santos e da Baixada Santista .20

Tabela II - Síntese das diferenças das propriedades geotécnicas das argilas marinhas da Baixada Santista 22

Tabela III - Síntese dos métodos apresentados para estabilização de recalques ....42

Tabela IV - Edifícios da orla do bairro da Ponta da Praia 45

Tabela V - Tabela resumo especificando os processos existentes e a sua localização. .56

Tabela VI - Análise das sondagens no trecho: Canal 3 - Canal 4. 67

Tabela VII - Análise das sondagens trecho: Canal 4 - Canal 5. 67

Tabela VIII - Análise das sondagens trecho: Canal 5 - Canal 6 68

Tabela IX - Análise das sondagens da Ponta da Praia .68

Tabela $X$ - Resistência de Ponta média e valores de $N_{S P T}$ médio ao longo da profundidade para os CPT's do bairro do Boqueirão .78

Tabela XI - Resistência de Ponta média e valores de $\mathrm{N}_{\mathrm{SPT}}$ médio ao longo da profundidade para o CPT's do bairro da Ponta da Praia .79

Tabela XII - valores de K propostos por Aoki e Velloso .83

Tabela XIII - Comparação entre os valores de campo, método de Aoki Velloso e Sanglerat para a Ponta da Praia .85

Tabela XIV - Resumo dos recalques obtidos para o bairro da Ponta da Praia e "Faixa Crítica". .95

Tabela XV - Relação dos recalques primários ( $\rho$ ), entre as regiões de estudo para o mesmo mecanismo de sobreadensamento. .95

Tabela XVI - Relação dos recalques primáios ( $\rho$ ), entre os mecanismos de sobreadensamento para uma mesma região 96 


\section{LISTA DE SIMBOLOS}

$\mathrm{N}_{\mathrm{SPT}}=$ número de golpes necessário para cravar $30 \mathrm{~cm}$ do amostrador, após uma cravação inicial de $15 \mathrm{~cm}$

$\mathrm{q}_{\mathrm{c}}=$ resistência de ponta

$q_{t}=$ resistência de ponta real mobilizada no ensaio

fs $=$ atrito lateral

$\mathrm{Bq}=$ parâmetro de classificação do solo no CPTU

$R f=$ razão de atrito $=f s / q_{c}$

$\mathrm{u}_{2}=$ pressão neutra medida na base do cone

$\mathrm{C}_{\mathrm{c}}=$ índice de compressão

$\mathrm{C}_{\mathrm{r}}=$ índice de recompressão

e= índice de vazios

$\sigma^{\prime} V_{i}=$ tensão vertical efetiva inicial

$\sigma_{\mathrm{Vf}}^{\prime}=$ tensão vertical efetiva final

$\sigma_{a}^{\prime}=$ tensão de pré-adensamento

$\rho=$ recalques

$\gamma_{n}=$ peso específico do solo natural

RSA = razão de sobreadensamento

$\mathrm{C}_{\mathrm{v}}=$ coeficiente de adensamento

$\mathrm{C} \alpha \varepsilon=$ coeficiente de adensamento secundário

$S_{u}=$ resistência não drenada do solo

$\mathrm{LL}=$ limite de liquidez

LP $=$ limite de plasticidade

$\mathrm{IA}=$ índice de atividade

$\mathrm{IP}=$ índice de platicidade 
$\delta=$ massa específica dos grãos

$\mathrm{Dr}=$ densidade relativa

$\phi=$ ângulo de atrito interno do solo

$E$ = módulo de deformabilidade do solo

$\mathrm{E}_{25}=$ módulo de deformabilidade para $25 \%$ da tensão deviadora 


\section{RESUMO}

A pesquisa aborda problemas de recalques que vem ocorrendo na Cidade de Santos desde o início dos anos 40, devido à implantação de edifícios sob fundação direta.

O trabalho destaca o Bairro da Ponta da Praia, onde os recalques ocorridos, principalmente os diferencias, foram bem menores que no restante da orla, e a região entre os canais três e seis, denominado pela autora "Faixa Crítica", onde estão concentrados diversos edifícios inclinados ao longo da orla.

Foi feita uma revisão bibliográfica envolvendo aspectos históricos, geológicos e geotécnicos sobre a cidade de Santos e os principais fatores que a tornaram tão conhecida pelos edifícios tortos ao longo de sua orla. Nessa revisão, apresentaramse dados sobre o subsolo de Santos, no contexto mais geral dos solos, a Baixada Santista. Foram reapresentados dados de alguns edifícios bastante recalcados e conhecidos na cidade e analisados métodos existentes para estabilização de recalques; alguns casos de aplicação foram relatados.

Os estudos foram baseados em uma grande quantidade de sondagens de simples reconhecimento coletadas na cidade; alguns ensaios do cone, CPT e CPTU, também foram analisados. Foi feita uma comparação entre as duas regiões Ponta da Praia e "Faixa Crítica", mostrando as diferenças nas espessuras e nas propriedades geotécnicas das camadas de areia superficial.

Foram feitos também cálculos para a previsão de recalques no bairro da Ponta da Praia e na "Faixa Crítica", levando-se em conta os mecanismos de sobreadensamento das argilas da Baixada Santista e diferenças nas espessuras da camada de areia superficial.

Com a análise das sondagens coletadas foi possível responder alguns questionamentos sobre o perfil geotécnico da Orla de Santos, traçar o perfil geotécnico da orla do bairro da Ponta da Praia e traçar seções no sentido transversal à orla, (praia-centro). 


\section{ABSTRACT}

The research concerns settlement issues occuring in the city of Santos since the 40's because of the building construction under shallow foundation.

The work emphasizes the neighborhood called Ponta da Praia where the settlements mainly the differentials, have been slighter than the rest of the seashore, and the region between the channels three and six, named by the author "the Critical Strip" several inclined buildings are concentrated along the seashore.

A bibliographic revision has been made involving historical, geological and geotechnical aspects about the city of Santos and the mainly facts which became the city well-known due to the inclined buildings along the seashore. The revision presented specific geotechnical data about the Santos subsoil, in the general context the Santos Coastal Plain, named Baixada Santista. Settlement data of some inclined buildings where also presented and current plumbing methods were evaluated and some application cases were reported.

The studies were based in a large amount of borings (SPT) executed in the city; and a couple of CPT and CPTU were analyzed. The differences between Ponta da Praia and "the Critical Strip" were pointed out related to the upper sand layer thickness as well as its geotechnical properties.

Also computations were made for the evaluation of settlement in the neighborhood Ponta da Praia an in the "the Critical Strip" taking into account the known clay overconsolidation mechanisms in the Baixada Santista and differences in upper sand layer thickness.

With the boring analyses it was possible to answer some questions about the existing geotechnical section of the neighborhood Ponta da Praia and to sketch crosssections transverse to the seashore (beach - city center). 


\section{CAPÍTULO I - INTRODUÇÃO}

\section{1 - O PROBLEMA DAS FUNDAÇÕES EM SANTOS}

A cidade de Santos é conhecida não só pelo belo jardim ao longo da praia, mas também por apresentar inúmeros problemas de recalques em edifícios apoiados na camada superficial de areia.

Desde o início da ocupação da orla praiana sabia-se da ocorrência de uma espessa camada de argila marinha mole no subsolo santista e dos recalques por adensamento que poderiam ocorrer. $O$ fato de a camada superficial de areia ser compacta, com tensão admissível de 250 a $300 \mathrm{kPa}$, levou construtores da época a executar edifícios com mais de 12 pavimentos apoiados em fundação direta, a 1,5$2,0 \mathrm{~m}$ de profundidade.

Com o passar dos anos, o número de edifícios e a quantidade de pavimentos, aumentaram significativamente gerando um acréscimo de tensões nas camadas de argila, quer pelo incremento da carga, quer pela interferência dos bulbos de pressão das construções vizinhas.

O resultado de tudo isso é facilmente hoje observado na cidade. Recalques chegaram a atingir $120 \mathrm{~cm}$. Inúmeros edifícios na Orla de Santos estão inclinados; ora um em direção ao outro, ora em direções opostas, e ainda alguns que recalcaram para um lado sem influência de prédios vizinhos.

Fato curioso notado, é que esses recalques diferenciais não ocorrem em toda orla; existe uma "Faixa Crítica" na praia de Santos onde está concentrado o maior número de prédios inclinados, facilmente perceptíveis a olho nu. Essa região compreende a área entre os canais 3 e 6 . No restante da orla os recalques, principalmente os diferenciais, foram bem menores. Na foto 01 é destacado a "Faixa Crítica" e o bairro da Ponta da Praia. 
No presente trabalho foram feitas comparações entre os edifícios do Bairro da Ponta da Praia, onde não existem prédios tortos, perceptíveis a olho nu, com os edifícios já estudados por outros pesquisadores e extremamente recalcados localizados na "Faixa Crítica" da Orla de Santos

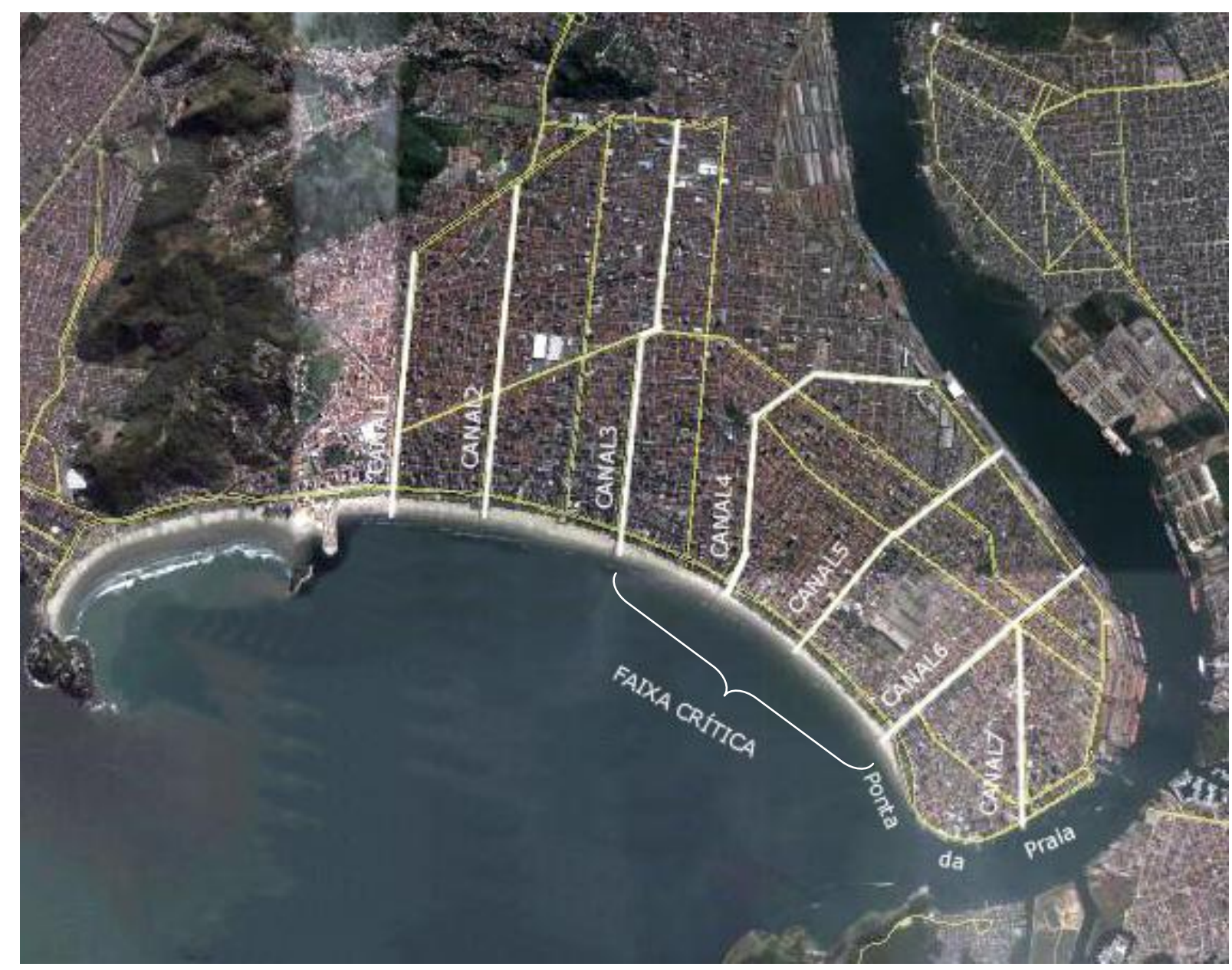

Foto 01 - Foto aérea da cidade de Santos. Em destaque a "Faixa Crítica" e o bairro da Ponta da Praia (Fonte: Adaptado de Google Earth - jan, 2008)

Teixeira (1994) traçou um perfil de toda Orla de Santos, sintetizando a ocorrência das camadas de areia e argila. Este perfil, embora precise de algumas adaptações, ainda é muito utilizado como referência para ilustrar o subsolo Santista (figura 01). Massad (2003) questionou a espessura da camada de areia no bairro da Ponta da Praia e a ocorrência de camadas mais profundas, adaptando o perfil de Teixeira de acordo com a figura02.

Gonçalves (2005) em sua Tese de Livre Docência mencionou a diferença de comportamento dos edifícios da região de estudo, levantando a seguinte questão: 
"será que as argilas mais próximas a Ponta da Praia tem características diferentes das argilas situadas próximo à Conselheiro Nébias?'

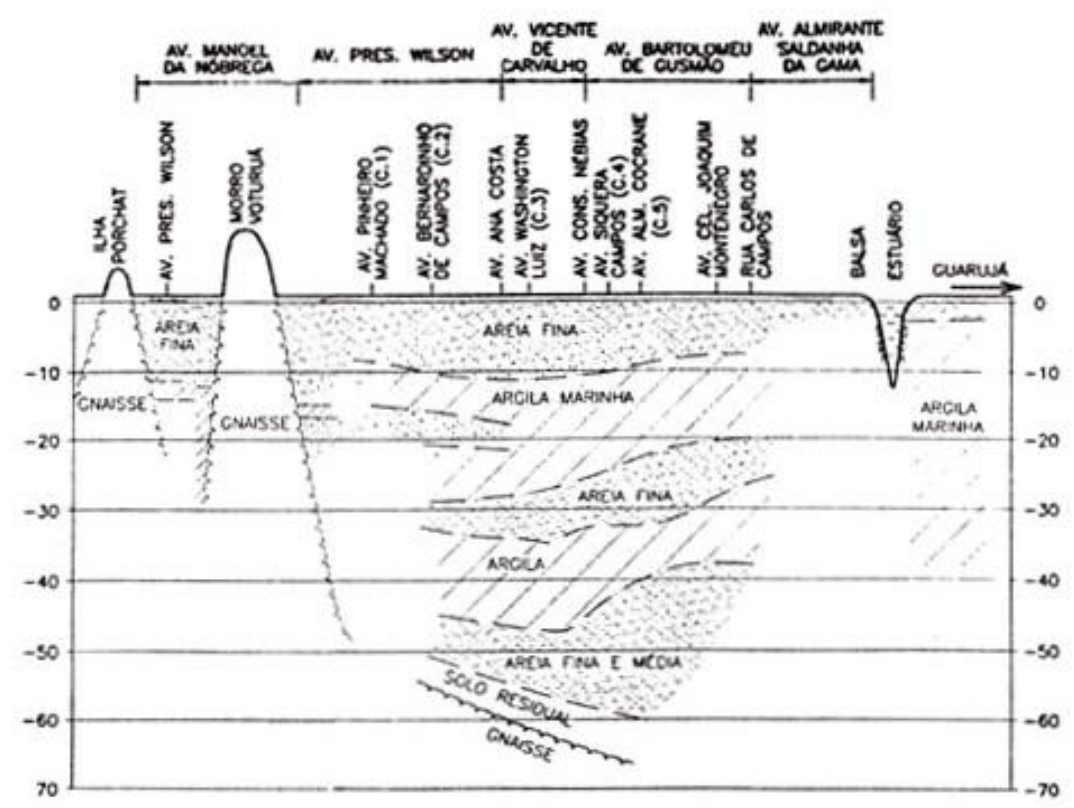

Figura 01 - Perfil Geotécnico sintético da Orla Praiana (Fonte: Teixeira, 1994)

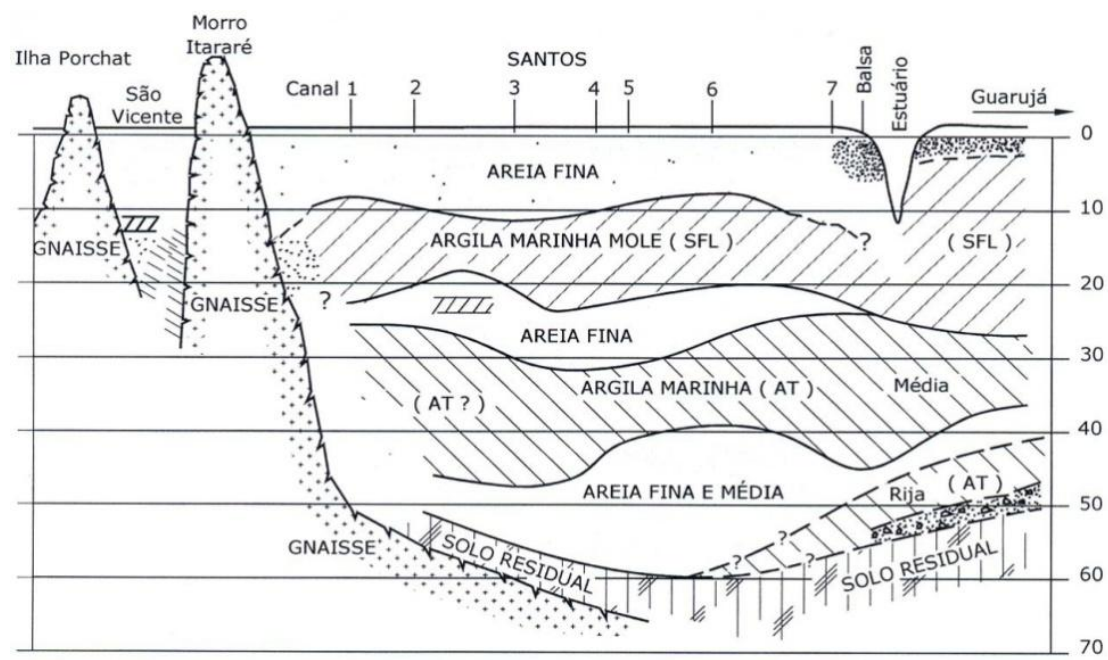

Figura 02 - Perfil Geotécnico sintético da orla praiana (Fonte: Adaptada de Teixeira (1994) por Massad (2003)

A ação de Dunas no passado levantada por Massad (2006 e 2008), explica o comportamento muitas vezes "anômalo" das argilas de Santos e a existência de regiões com maior tensão de pré-adensamento, tendo como conseqüência, menores recalques ou recalques diferenciais. 


\section{2 - OBJETIVO}

Fazem parte do escopo desse trabalho:

a) Esclarecer os questionamentos levantados por Massad (2003) na figura02;

b) Traçar uma nova seção geotécnica da orla da Ponta da praia, através de um levantamento de sondagens executadas na região e também, traçar uma seção geotécnica sintética no sentido perpendicular a Orla de Santos (Praia - Centro);

c) Verificar a influência da ação de dunas e da espessura da primeira camada de areia nos recalques no bairro da Ponta da Praia. 


\section{CAPÍTULO II - REVISÃO BIBLIOGRÁFICA}

\section{1 - ASPÉCTOS HISTÓRICOS}

\subsection{1 - Da colonização até fins do século XX}

Por volta de 1530, a llha de Santo Amaro (figura 03) foi escolhida por Martim Afonso para desembarque e primeira residência de seu povo.

Pouco tempo depois as atenções se voltaram para São Vicente, que nessa época era constituída de um conjunto de 10 ou 12 casas e se tratava do caminho mais certo e seguro para as entradas ao sertão.

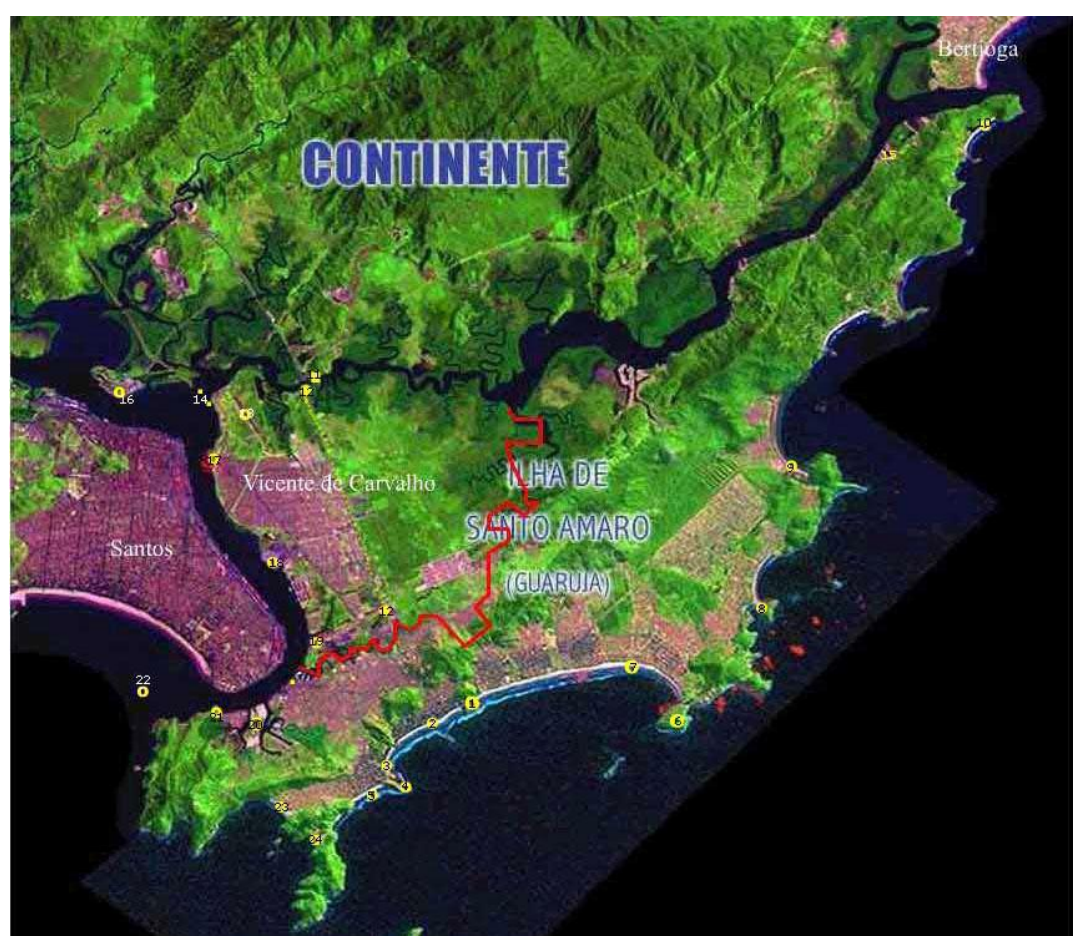

Figura 03 - Ilha de Santo Amaro - A linha vermelha no mapa, representa a divisória entre a sede do Município de Guarujá e o Distrito de Vicente de Carvalho (Fonte: http://br.geocities.com, fev, 2008) 
Fatores geográficos e históricos fizeram com que ainda na década de 1530-40, pouco depois da fundação de São Vicente, surgisse o povoado Santista. Santos cresceu rapidamente sendo elevada à categoria de vila em 1546.

Em função da definição do porto de Santos, localizado bem no interior do estuário, deu-se o desligamento do ancoradouro da foz do rio Santo Amaro e como conseqüência, abandono dos trajetos anteriormente utilizados.

"Santos nascera assim, sob bons signos" (Araújo Filho, 1964). Tudo levara a crer que o desenvolvimento da cidade se daria como o de Olinda, fundada na mesma época, e comandada pela economia da cana-de-açúcar.

Mas o que se previu não aconteceu: a lavoura canavieira no litoral vicentino não durou muito tempo, sua decadência foi tão rápida quanto sua implantação. Um dos fatores dessa decadência está relacionado com a distância entre a área vicentina produtora e os mercados consumidores europeus, distâncias que, evidentemente, devem ser consideradas em termos de tempo.

Além da distância, a formação Geológica da Baixada Santista contribuiu negativamente para a implantação de uma lavoura canavieira. Formada por uma planície sedimentar-quaternária, constituída predominantemente de areias e argilas, sendo uma superfície baixa, rigorosamente plana e sub-horizontal.

os solos da planície ou estão nas dunas e nas restingas arenosas, ou nos manguezais encharcados e nos vales sujeitos a inundações periódicas. Fora daí e nos morros íngremes, pouco espaço exista para que o colono pudesse aproveitá-los economicamente com a agricultura (Araújo Filho, 1964)

Santos foi elevada á categoria de cidade em janeiro de 1839. Mesmo assim, até o início do século XIX, a cidade evoluiu pouco, sofria constantemente com o fato de ser uma planície e inundava-se facilmente. A foto 02 retrata a cidade de Santos, anos após sua fundação. 


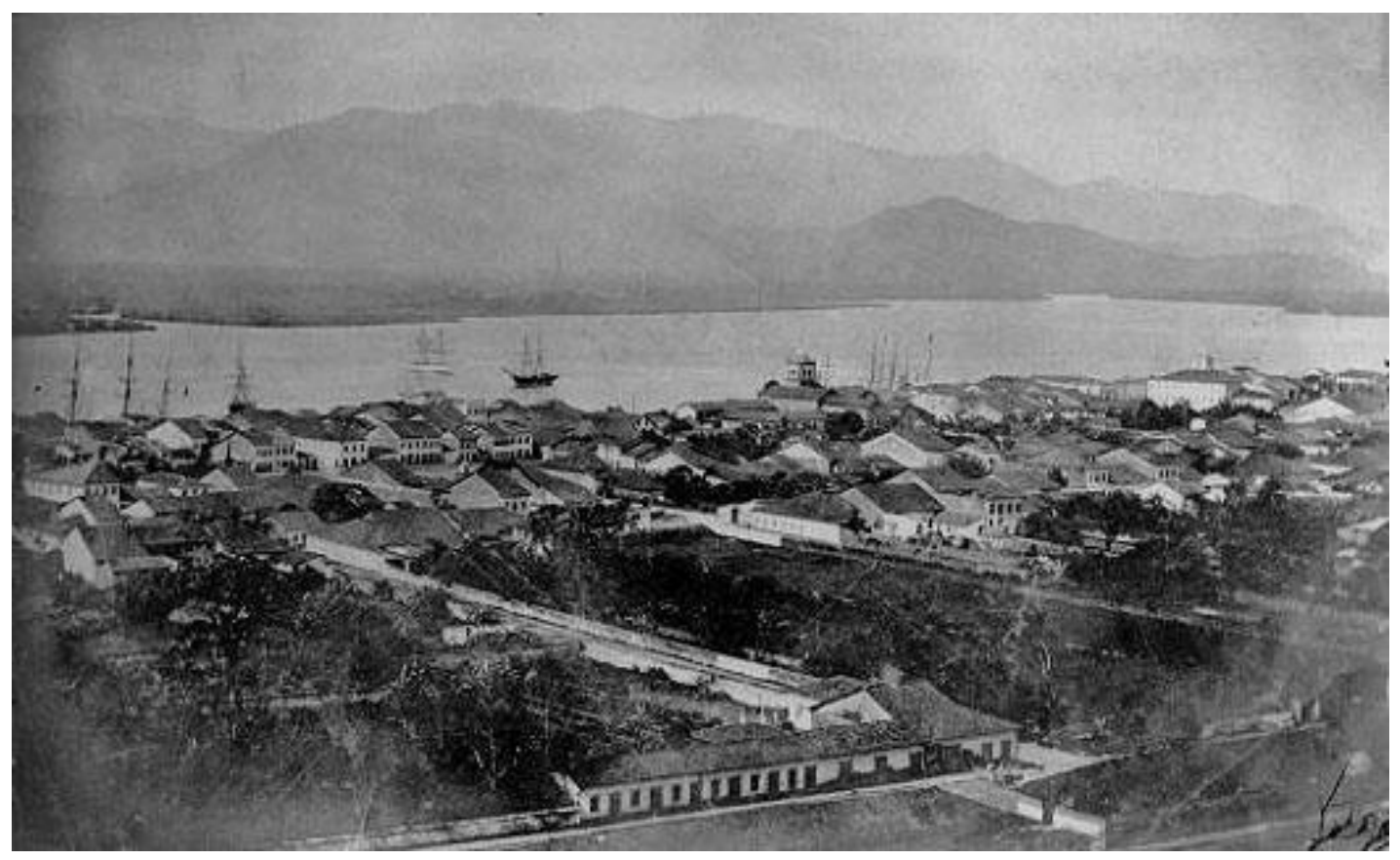

Foto 02 - Santos em 1865 (Fonte: http://www.novomilenio.inf.br - foto de Militão Augusto de Azevedo, jul, 2008).

Por mais de três séculos e meio, o Porto de Santos, embora tivesse crescido, manteve-se em padrões estáveis com o mínimo de mecanização e muita exigência de trabalho físico.

A partir da década de 50, o café começou a se tornar o principal produto de exportação paulista. Por volta de 1854 , Santos já exportava quase $80 \%$ do café brasileiro. Isso fez com que a antiga vila crescesse rapidamente. O número de habitantes aumentava a cada dia, mas a cidade não tinha sistema de esgoto nem casas suficiente para abrigar toda a população. As condições de higiene e salubridade ficaram altamente comprometidas, propiciando o aparecimento de doenças de caráter epidêmico. A construção de um porto organizado era mais do que necessária para mudar o cenário da cidade, e dar infra-estrutura para seu desenvolvimento.

Com o desenvolvimento de um novo Porto, iniciou-se também uma nova fase para a vida da cidade, pois antes da instalação do porto organizado, Santos contava com precários trapiches de madeira para o acesso aos navios de passageiros e cargas (ver foto 03). Esses trapiches começaram a ser demolidos e as pontes fincadas em terrenos lodosos, foram sendo substituídos por aterros e muralhas de pedra. 
Uma via férrea e novos armazéns para guarda de mercadorias, compunham as obras do novo porto.

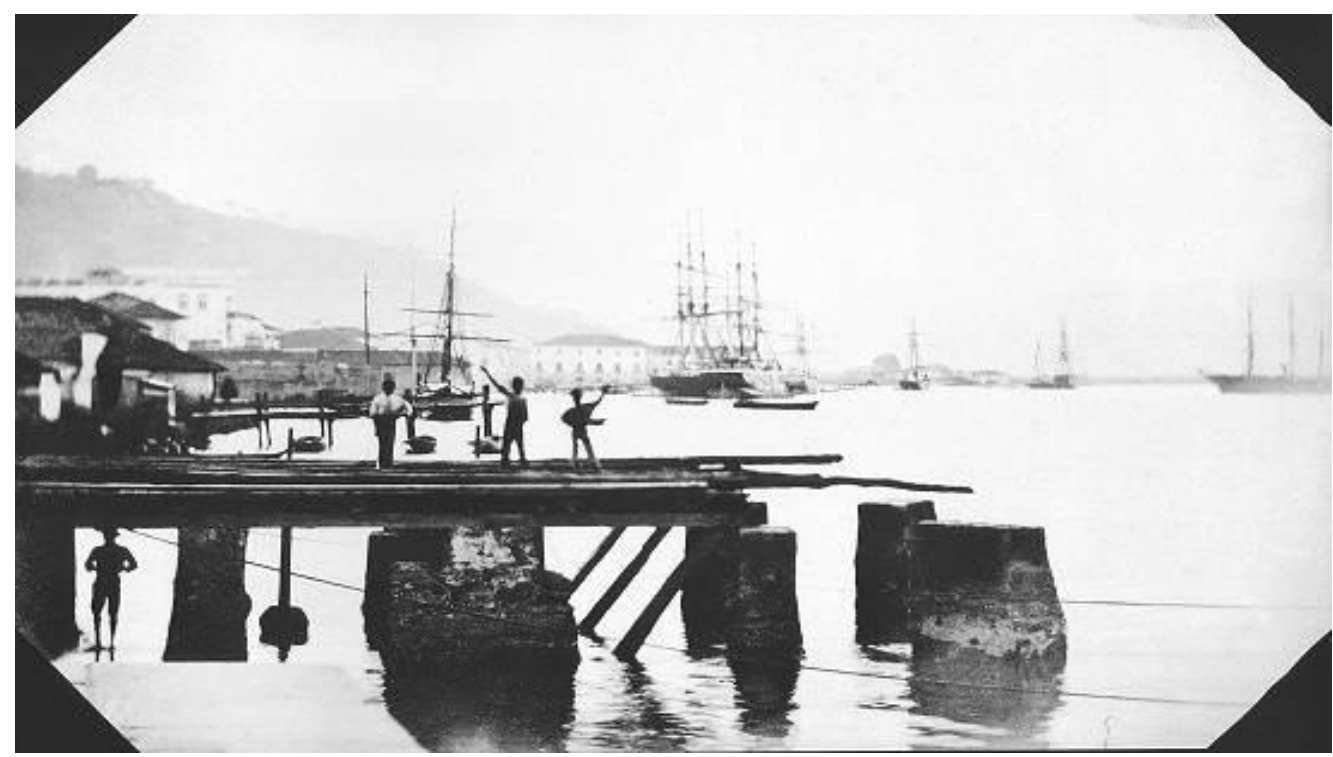

Foto 03 - Porto de Santos próximo à Alfândega por volta de 1860 ainda com trapiches (Fonte: http://www.novomilenio.inf.br - foto de Militão Augusto de Azevedo, jul, 2008)

O início das obras de construção do porto ocorreu efetivamente em 1888 e, em fevereiro de 1892, foi oficialmente inaugurado o Porto de Santos, quando a Companhia Docas de Santos - CDS, entregou à navegação mundial os primeiros $260 \mathrm{~m}$ de cais, na área, até hoje denominada, Valongo.

Nessa época também começaram a ser delineados os projetos urbanísticos de Santos. Em 1905 o engenheiro sanitarista Francisco Saturnino Rodrigues de Brito foi contratado para elaborar um plano de saneamento que resolvesse os alagamentos e pusesse fim às epidemias que mataram milhares de pessoas.

Saturnino de Brito foi o elaborador do gigantesco plano de saneamento que incluiu os canais de drenagem e a Ponte Pênsil (inaugurada em 1914), para dar suporte aos emissários do esgoto de Santos, cujos dejetos eram lançados ao mar, na ponta de Itaipu.

O surto cafeeiro também fez a Província, ainda no primeiro quartel do século XIX, discutir a abertura de uma nova estrada entre São Paulo e Santos, que permitiria também a passagem de veículos. 
se o caminho de Santos para São Paulo não tivesse todas as ditas dificuldades, viriam a Santos mais moradores de Serra acima com mantimentos para venderem, e levarem o produto em sal. (...) é muito dificultoso o dito caminho, porque sendo em partes áspero, e pantanoso, há muitos anos que não tem benefício algum, em todo o tempo custa passar, e no de águas se reduz quase a impraticável. Algumas vezes comerciantes ficam parados em Santos seis e oito meses a espera de tropas possam encetar o caminho (Pereira, apud Petrone, 1964)

Os estudos para abertura de uma nova estrada se deram por muitos anos, até que em 1841 se deu o início das obras e em 1846 foi inaugurada a nova estrada, chamada de estrada da Maioridade.

Entretanto a inauguração da nova estrada não implicou que a mesma estivesse em condições satisfatórias de transito, "a estrada da maioridade continuou sendo, antes de mais nada, uma estrada de tropas." (Petrone, 1964)

Os anos se passaram o desenvolvimento da economia portuária continuou em crescimento e o antigo caminho que antes era feito não apenas com o auxílio das pernas, mas também das mãos, passou para as voltas superpostas da estrada da Maioridade, e finalmente deu lugar aos túneis, pontes e viadutos da até hoje chamada Via Anchieta. (Petrone, 1964)

\subsection{2 - A expansão urbana de Santos}

Com um eficiente sistema de esgotos e de canais de drenagem, Santos ficou limpa, e livre de epidemias. A população pode crescer e construir nos terrenos saneados, inclusive em direção às praias.

Por volta de 1940, iniciou-se a ocupação da orla marítima, que passou a ser considerada a área nobre da cidade. Até o início do século XX a paisagem da orla praiana de Santos era composta por chácaras de veraneio, pertencentes aos negociantes da cidade; à medida que a cidade foi crescendo, essas chácaras foram substituídas por aqueles que podiam construir seus palacetes com vista para o mar. 
"Em poucos anos, quase toda a extensão da praia, do José Menino às proximidades da Ponta da Praia, foi ocupada, formando um conjunto residencial dos mais elegantes de Santos." (Araújo Filho, 1964).

Com a crise do café em 1929, os antigos palacetes se transformaram em pensões, onde a classe média se hospedava aos finais de semana ou dias de folga.

A abertura da via Anchieta, relatada acima, ofereceu extrema facilidade na comunicação entre a Baixada Santista e São Paulo. Dessa forma, os antigos palacetes deram lugar aos edifícios de hoje, sendo que a maior parte dos apartamentos eram ocupados pelos veranistas somente aos finas de semana ou em época de férias.

"O fato é que, em menos de uma década, verdadeira muralha de arranha - céus passou a cobrir as praias santistas e vicentinas, transformando suas paisagens $e$ criando sérios problemas para ambos os aglomerados." (Araújo Filho, 1964).

\section{2 - ASPÉCTOS GEOLÓGICOS}

\subsection{1 - Geologia do litoral}

O litoral do Estado de São Paulo é caracterizado por planícies sedimentares, separadas por rochas elevadas do embasamento cristalino Pré-Cambriano, que alcançam o mar (figura 04).

De acordo com Suguio e Martin (1978 e 1994), os limites mais importantes do embasamento pré-cambriano, do sul para o norte, podem ser definidos em cinco unidades morfológicas: Cananéia/Iguape, Itanhaém/Santos, Bertioga/lha de São Sebastião, Caraguatatuba/ Ubatuba e Baía de llha Grande, onde a primeira unidade encontra-se preenchida por depósitos quaternários e a linha da praia é praticamente retilínea; para o Norte as planícies se tronam cada vez menos preenchidas até que escassos depósitos quaternários acham-se presentes. 


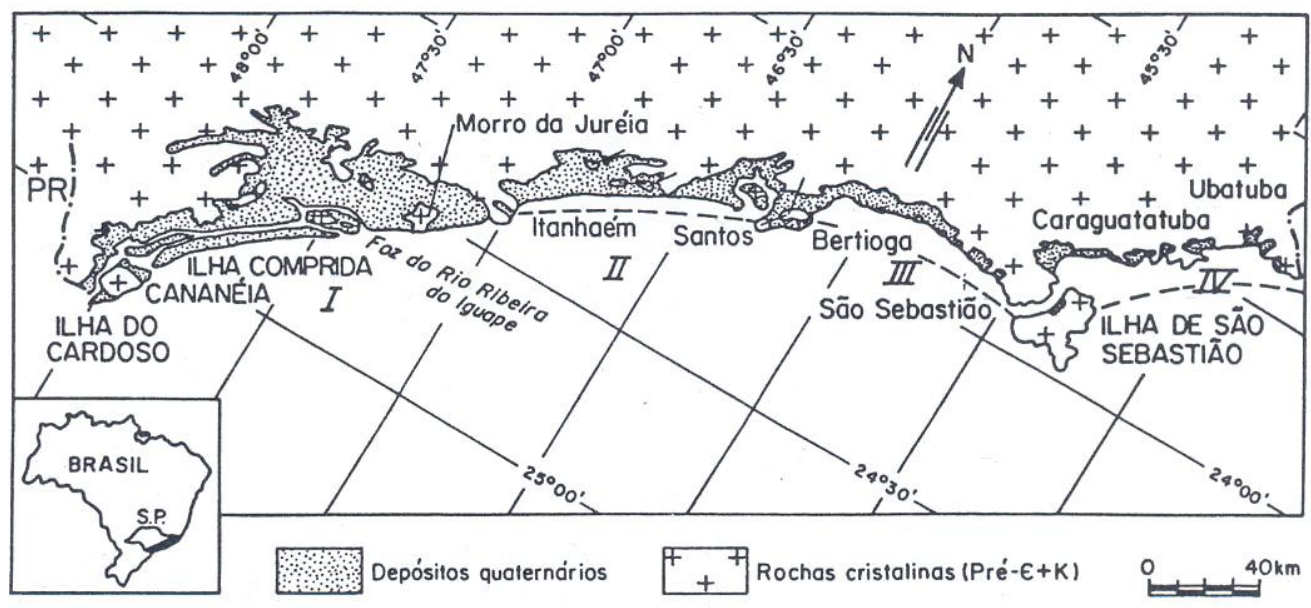

Figura 04 - Planícies Costeiras quaternárias do Litoral Paulista distribuídas em quatro compartimentos morfológicos (Fonte: Suguio e Martin, 1994)

Segundo Rodrigues (1964), o trecho da Baixada Santista compreendido entre Mongaguá e Bertioga apresenta uma base geológica bem simples, apresentado na figura 05:

(1) o embasamento cristalino, com rochas duras, relevo quase sempre muito acidentado, e coberto por um manto residual devido ao intemperismo (regolito); (2) a cobertura sedimentar cenozóica. Daí a dualidade de relevo da baixada: acidentado nos trechos correspondentes ao embasamento, plano nas áreas de sedimentação (figura 05). Afloramento do embasamento, além da ilha da costa, geram numerosas ilhas.

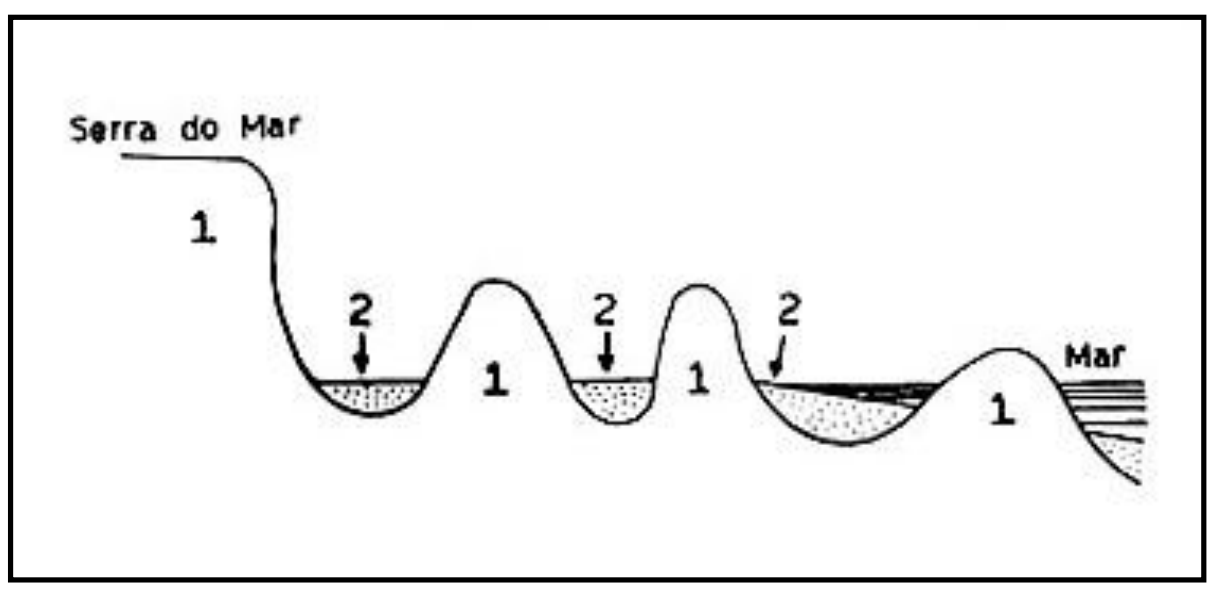

Figura 05 - Esquema da Geologia da Baixada litorânea Santista.(Fonte: Rodrigues, 1964) 
No que diz respeito às águas subterrâneas na Baixada Santista, podemos dividir os terrenos em três grupos:

- Planície enxuta: o lençol freático encontrado em pequenas profundidades, raso.

- Paludais: o lençol freático tangencia ou corta a superfície do terreno

- Morros: geralmente o lençol freático se encontra abaixo do contato solo - rocha.

$\mathrm{Na}$ figura 06, é retratado o lençol freático na Baixada Santista.

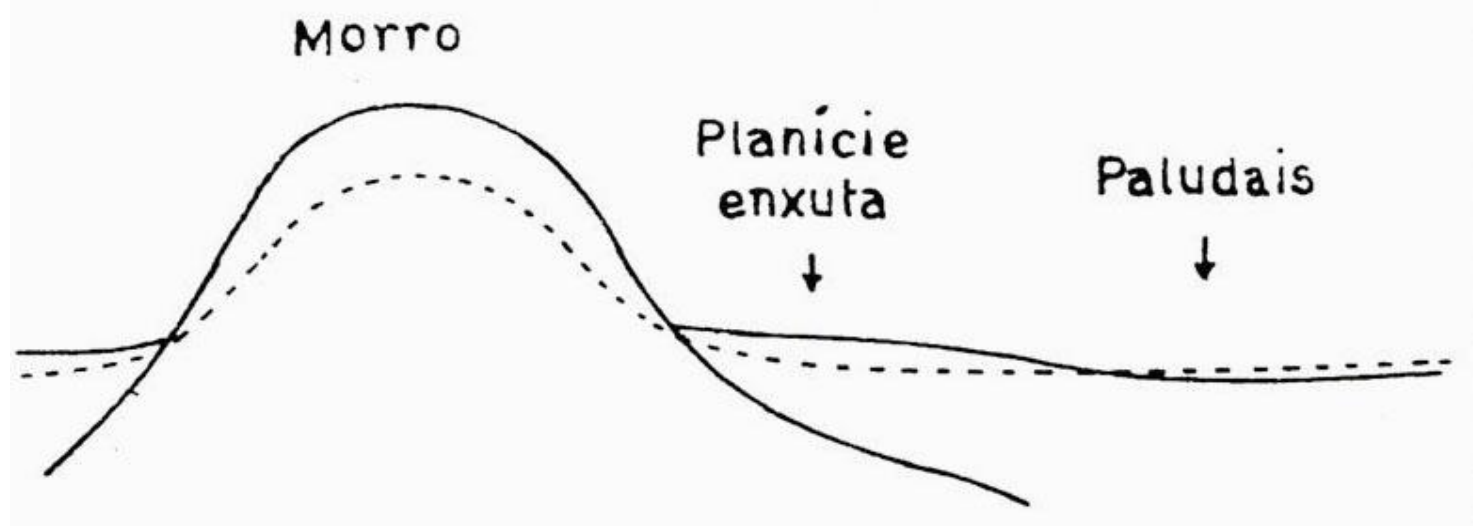

Figura 06 - Lençol freático na Baixada Santista. (Fonte: Rodrigues, 1964).

\subsection{2 - Influência das elevações do nível do mar na Baixada Santista}

De acordo com Suguio (1996), até a década de 60, pesquisas sobre flutuações do nível do mar durante o Quaternário eram muito escassas no Brasil. Após 1974 foram intensificados os estudos sobre as mudanças de nível relativo do mar, principalmente nos últimos 7500 anos.

De acordo com os estudos de Suguio e Martin (1978, 1981), verificou-se que na região de Santos - Bertioga, o nível máximo relativo do mar foi atingido por volta de 5100 anos, situando-se 4,5m acima do nível atual, por volta de 3500 anos o nível do mar passou por um segundo máximo atingindo $+4,0 \mathrm{~m}$ e há cerca de 2000 anos o nível do mar estava entre 1,5 e 2,0 m. A figura 07 ilustra essas variações. 
Os depósitos sedimentares da Baixada Santista se formaram nos últimos 120.000 anos por processos transgressivos - regressivos e foram fortemente influenciados pelas variações relativas do nível do mar. Essas formações estão diretamente relacionadas com dois ciclos de elevações do nível do mar:

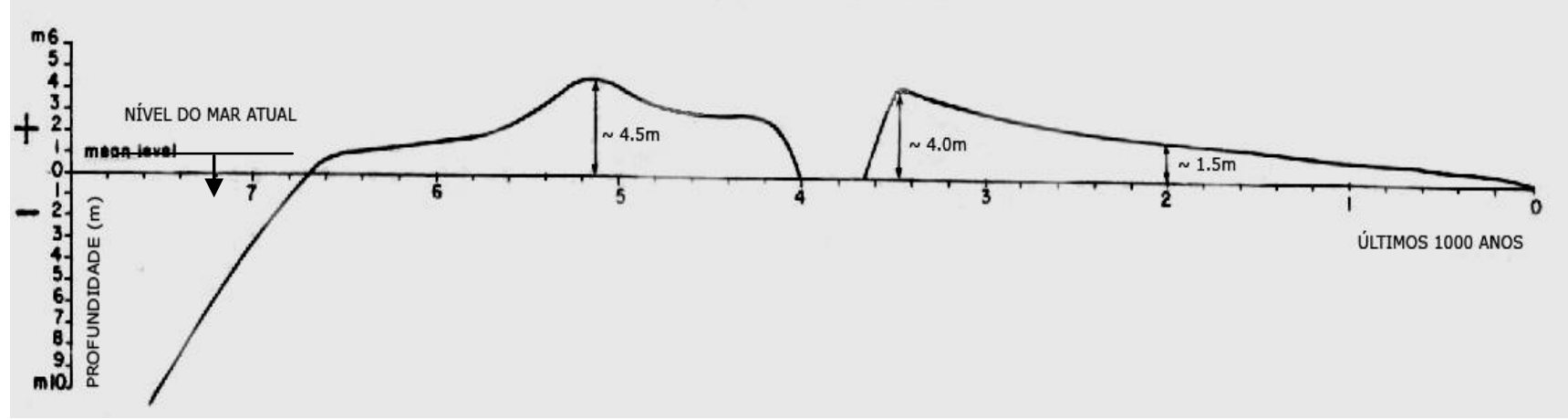

Figura 07 - Curvas de variação do nível relativo do mar durante os últimos 7.500 anos no trecho compreendido entre Santos - Bertioga. (Fonte: Suguio e Martin, 1978)

O primeiro é conhecido como Transgressão Cananéia, depositado há 100.000 120.000 anos. Processo que deu origem às Argilas Transicionais e Areias Transgressivas. O nome "Transicional" é devido ao ambiente misto, continental marinho de sua formação. Como conseqüência da regressão ocorrida, onde o nível do mar abaixou $110 \mathrm{~m}$ em relação ao atual, os sedimentos passaram por um intenso processo erosivo, apresentam - se fortemente sobreadensados por peso total. (Massad 1985 e 1999).

O segundo é chamado de Transgressão Santos, deu origem a Sedimentos Flúvio - Lagunares e de Baias (SFL). Essa formação, mais recente se deu cerca de 7000 5000 anos. O nome "SFL" é devido ao fato de às vezes se formarem pelo retrabalhamento dos sedimentos da Formação Cananéia e outras por sedimentação em Lagunas e Baias. (Massad 1985 e 1999).

\subsection{3 - Planícies sedimentares quaternárias de São Paulo}

Suguio e Martin (1981), com o brilhante trabalho sobre as flutuações do nível do mar e a evolução costeira do Brasil, conseguiram propor um modelo geológico para explicar a formação das planícies quaternárias do Estado de São Paulo (figura 08), 
apontando as elevações do nível do mar como causa principal da origem dos depósitos sedimentares.

A evolução destas planícies foram resumidamente divididas em cinco etapas:

1ํ№ auge da transgressão Cananéia o mar atingiu o pé da Serra do mar e se formaram os sedimentos argilo-arenosos chamados transicionais e as areias marinhas transgressivas.

$2^{0}$ Iniciou-se o processo de regressão e com isso cordões de areias regressivas foram depositados sobre os sedimentos transgressivos que posteriormente foram retrabalhados pela ação do vento.

3ํㅜㄹ vor volta de 17.000 anos atrás o nível do mar abaixou até a cota $-110 \mathrm{~m}$, com isso os sedimentos superficiais da formação Cananéia foram erodidos, formando vales profundos. Com cordões de praias, a superfície original da formação Cananéia foi preservada ficando entre os vales.

4ํ Com a Transgressão Santos o mar subiu rapidamente e invadiu as zonas rebaixas pela erosão, originando um longo sistema de lagunas, onde sedimentos argilo - arenosos foram depositados. Em conjunto com isso, as partes mais altas da Formação Cananéia foram erodidas pelo mar e as areias redepositadas, dando origem aos depósitos marinhos holocênicos arenosos.

5 O mar retornou para a sua posição atual e assim se formaram cordões litorâneos de regressão. Diferentes gerações desses cordões podem ser notados como conseqüência das flutuações do nível do mar durante a o final da Transgressão Santos. 


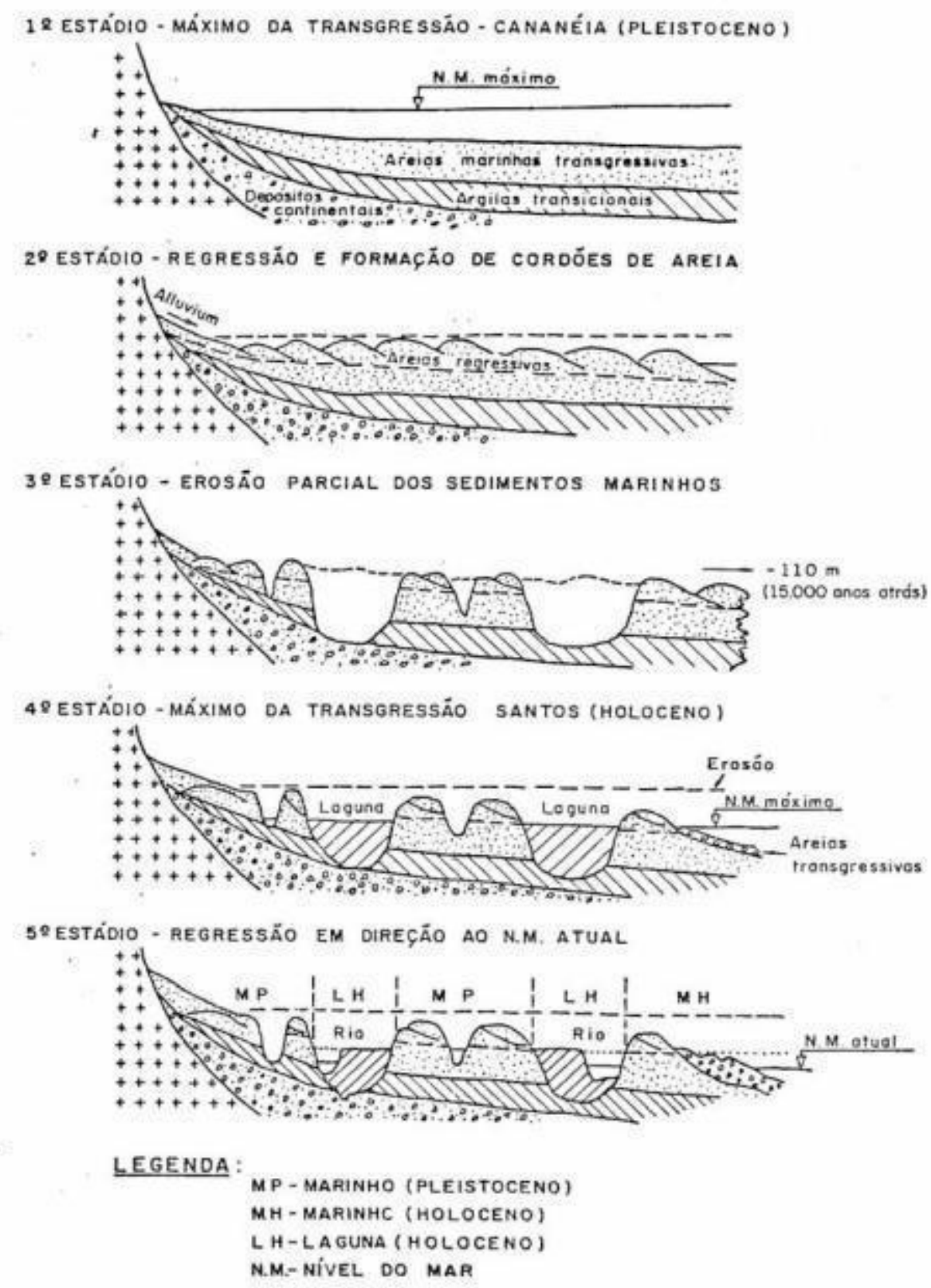

Figura 08 - llustração da formação das planíces quaternárias do Estado de São Paulo. (Fonte: Suguio e Martin, 1978)

\subsection{4 - As ilhas barreiras e os sedimentos flúvio lagunares}

De acordo com Suguio e Martin (1981, 1994), nos períodos em que o continente esteve submerso, formaram-se algumas llhas Barreiras, lagunas e baías, que enquanto condição do nível do mar era quase estável, estas permaneceram parcialmente isoladas por longos períodos de tempo. Após 4000 anos de emersão, o nível do mar abaixou e essas ilhas barreiras se deslocaram em direção ao 
continente gerando cordões de areia nas suas extremidades, isolando ainda mais as lagunas e baías do alto mar e provocando seu secamento.

Segundo Suguio (1996) as Ilhas Barreiras se deslocam devido a:

a) Ação dos Ventos (perda de areia para as dunas)

b) Deriva Litorânea

c) Equilíbrio de Plataforma

A ação eólica no litoral brasileiro resulta em uma constante perda de areia para as Dunas. Na Baixada Santista, a ação dos ventos sobre os sedimentos arenosos remanescentes às transgressões Cananéia e Santos, deram origem a dunas como as encontradas na llha de Santo Amaro (Conforme Mapa Geológico Preliminar da Baixada Santista, 1973 citado por Massad, 1985) e em Praia Grande (Rodrigues, 1964).

Por definição, "deriva litorânea são correntes induzidas por ondas que se aproximam obliquamente do litoral. Estas correntes movimentam enorme quantidade de sedimento que são transportados ao longo do litoral". (Dicionário Pro - Disponível em: http://www.dicionario.pro.br)

$\mathrm{Na}$ maioria das vezes as areias ao longo de uma praia são transportadas por correntes longitudinais geradas pelas ondas, pois próximo às praias, as ondas não encontram profundidade suficiente para avançar e se arrebentam.

Este fenômeno libera grande quantidade de energia, sendo que parte desta energia é usada para colocar as areias em suspensão e outra parte para gerar correntes de deriva litorânea.

Embora a velocidade desta corrente seja lenta, sua influência nas areias em suspensão através da quebra de ondas é muito grande; dessa forma, um grande volume de areia é transportado. O transporte por deriva litorânea prossegue até que as areias sejam retidas por uma armadilha (reentrâncias da linha costeira, ilhas ou fundos rasos) ou bloqueadas por um obstáculo.

Uma vez atingido o perfil de equilíbrio de uma zona litorânea, elevação ou descida subseqüente de nível relativo do mar perturbará este equilíbrio, que será então restaurado mediante translação da linha praial rumo ao continente. Se houve elevação do nível do mar, o prisma praial sofrerá erosão e o material erodido será 
transferido, resultando em um recuo da linha da costa; se ocorreu descida do nível do mar, as ondas irão movimentar os sedimentos rumo ao prisma praial, provocando o avanço da linha da costa.

O processo de formação da llhas Barreiras pode ser exemplificado através da figura 09, fato que ocorre hoje em Cape Hateras, ocorreu no Brasil há cerca de 5100 anos Figura 09 (a) - Continente submerso

Figura 09(b) - Formação das llhas barreiras e lagunas, que após abaixamento do nível do mar se deslocaram em direção ao continente, formando cordões de areia nas suas partes externas.

Figura 09(c) Os cordões de areia isolaram completamente as lagunas do alto mar e provocaram seu secamento, mais tarde deu-se a deposição de sedimentos argiloarenosos fluviais.

Este modelo de deposição de sedimentos foi aplicado à Baixada Santista por Massad (2003 2004 e 2006). Além de delimitar dois núcleos com processos de sedimentação distintos, Massad mostrou também que as Ilhas-Barreiras deram origem às areias de Praia Grande, Santos e Guarujá.

a) CAPE HATERAS (USA) SITUAÇÃO ATUAL

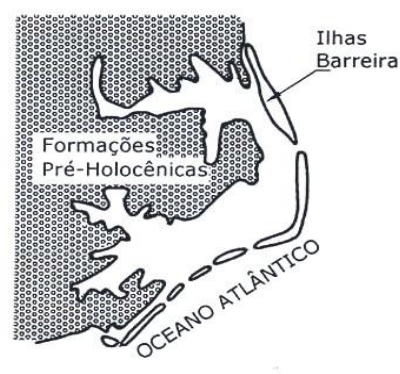

$30 \mathrm{~km}$ b) FOZ DO RIO DOCE (ES) SITUAÇÃO HÁ 5.100 ANOS

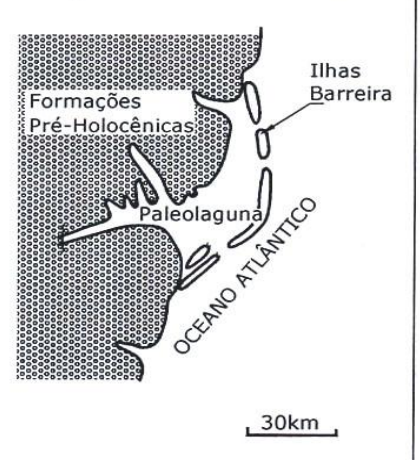

c) FOZ DO RIO DOCE (ES) SITUAÇÃO ATUAL

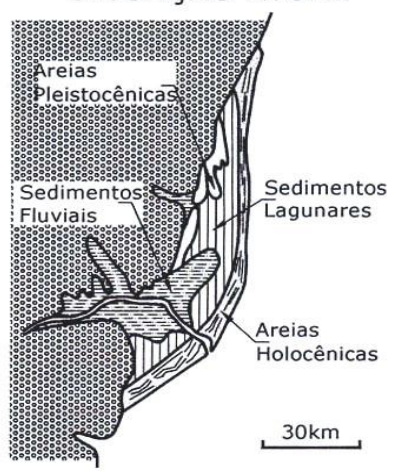

Figura 09 - llustração da Formação da llhas Barreiras (Fonte: Apud Massad, 2004 e 2006). 


\section{3 - ASPECTOS GEOTÉCNICOS}

\subsection{1 - Pressão de pré - adensamento e origem do sobreadensamento}

A pressão de pré-adensamento $\left(\sigma^{\prime}\right.$ a) é definida como a maior tensão efetiva que o solo já sofreu. Diz-se que um solo é normalmente adensado quando a pressão de pré-adensamento $\left(\sigma^{\prime}\right.$ a) é igual a tensão efetiva a que o solo está submetido $\left(\sigma_{\mathrm{vi}}^{\prime}\right)$. Quando $\left(\sigma^{\prime} \mathrm{a}\right)$ é maior que $\left(\sigma_{\mathrm{vi}}^{\prime}\right)$, o solo encontra-se sobreadensado. A razão de sobreadensamento ainda é a relação entre essas duas tensões, $\left(\sigma^{\prime} a\right) /\left(\sigma_{\mathrm{vi}}^{\prime}\right)$.

Massad (1985, 1994 e 1999), concluiu que o sobreadensamento das argilas da Baixada Santista ocorrem principalmente devido a três fatores:

- oscilação negativa do nível do mar durante os últimos 7.500 anos;

- ação de dunas eólicas;

- envelhecimento das argilas (efeito "aging" proposto por Bjerrum, 1967)

O envelhecimento das argilas ("aging"), ou adensamento secundário, é o fenômeno de reorientação das partículas sob tensão efetiva constante, onde ocorre uma redução do índice de vazios levando a uma configuração mais estável da estrutura do solo. Com o rearranjo de partículas ocorre um ganho de resistência do solo que aumenta com o tempo de aplicação dessa tensão.

O forte sobreadensamento das Argilas Transicionais com RSA (razão de sobre adensamento) da ordem de 2,5 a 4 e pressões de pré-adensamento variando de 300 a $600 \mathrm{kPa}$, é proveniente do grande abaixamento do nível do mar, que atingiu $-110 \mathrm{~m}$ há 17.000 anos.

Quanto aos Sedimentos Flúvio-Lagunares, Massad concluiu tratar de solos levemente sobreadensados, com RSA variando de 1,3 a 2 e pressões de préadensamento, de 30 a $200 \mathrm{kPa}$. Esse sobre adensamento também foi atribuído mais às oscilações negativas do nível do mar que à ação de dunas. e efeito "aging".

Estudos feitos por Massad e Perez (1997) em solos próximo a Rodovia dos Imigrantes, em um edifício na Orla de Santos e na llha de Santo Amaro, próximo ao Cais Conceiçãozinha, permitiu dividir em percentuais a contribuição dos principais efeitos que explicam o sobreadensamento das argilas SFL da Baixada Santista. 
a) Para o solo da Rodovia dos Imigrantes, chegaram à conclusão que $86 \%$ do sobreadensamento é devido as oscilações negativas do nível do mar, e 14\% devido ao envelhecimento das argilas; para o solo da orla de Santos, obtiveram-se $71 \%$ para as oscilações do N.A e $29 \%$ ficou por conta do "aging".

b) Para o solo da llha de Santo Amaro, próximo ao cais Conceiçãozinha, não foi possível obter valores coerentes para a combinação dos dois efeitos. Nesse caso concluíram que o sobreadensamento foi devido também ao peso de dunas existentes no passado; “(...) seria necessário admitir que tenha existido no local uma espessa camada de areia acima do nível do mar (...)" (Perez e Massad, 1997)

Massad, 2009, destaca que a hipótese exclusiva de envelhecimento (aging) das argilas SFL não se sustenta: "o pré-adensamento provocado pelas oscilações do nível do mar, sobrepôs-se ao efeito do "aging", mascarando-o com um mecanismo compreensível”.

Fato hoje, totalmente aceito e confirmado pelo comportamento de obras civis na Baixada Santista, é que as argilas de Santos são sobreadensadas e não normalmente adensadas, como se admitiu durante décadas.

\subsection{2 - Propriedades geotécnicas dos sedimentos da Baixada Santista}

Além dos valores de SPT outros parâmetros são muito importantes para a caracterização das argilas moles da Baixada Santista. Para a construção de alguns edifícios na cidade de Santos, vários ensaios foram executados no local de implantação, e parâmetros geotécnicos foram obtidos. A tabela I, elaborada por Massad, 2003 apresenta esses valores para quatro edifícios em diversos locais da Cidade e ainda uma comparação com os parâmetros geotécnicos da Baixada Santista. 
Tabela I - Parâmetros geotécnicos de Santos e da Baixada Santista (Massad, 2003)

\begin{tabular}{|c|c|c|c|c|c|c|c|}
\hline \multirow{3}{*}{$\begin{array}{l}\text { CARACTE- } \\
\text { RÍSTICAS }\end{array}$} & \multicolumn{5}{|c|}{ CIDADE DE SANTOS } & \multicolumn{2}{|c|}{ BAIXADA SANTISTA } \\
\hline & \multicolumn{2}{|r|}{$s$} & \multicolumn{2}{|c|}{ SFL } & \multirow{2}{*}{$\begin{array}{c}\text { AT } \\
\text { I } \\
(4)\end{array}$} & \multirow[b]{2}{*}{ SFL } & \multirow[b]{2}{*}{ AT } \\
\hline & $\begin{array}{l}C / D \\
(1)\end{array}$ & $\begin{array}{c}U \\
(2)\end{array}$ & $\begin{array}{l}\text { UNISAN- } \\
\text { TA (3) }\end{array}$ & $\begin{array}{c}\text { NÚNCIO } \\
\text { MALZ. } \\
\text { (3) }\end{array}$ & & & \\
\hline $\mathrm{z}$ - PROF. (m) & $8 \leq 7 \leq 20$ & $7 \leq z \leq 22$ & $15 \leq \pi \leq 24$ & $z=16$ & $14 \leq z \leq 43$ & $\leq 50$ & $20 \leq z \leq 45$ \\
\hline $\mathrm{e}$ & $1,2-2,4$ & $1,2-2,2$ & $1,6-2,2$ & - & 2,1 & $2-4$ & $<2$ \\
\hline $\bar{\sigma}_{a}(\mathrm{kPa})$ & $100-230$ & $80-200$ & $190-245$ & - & $600-700$ & $30-200$ & $200-700$ \\
\hline $\operatorname{RSA}(*)$ & 1,25 & 1,13 & $1,4 ?$ & 1,3 & $>3,5$ & $1,1-2,5$ & $>2,5$ \\
\hline SPT & - & - & $2-5$ & $1-4$ & $5-10(* *)$ & $0-4$ & $5-25$ \\
\hline $\mathrm{s}_{\mathrm{u}}(\mathrm{kPa})$ & $25-50$ & $25-90(\mathrm{CS})$ & $60-73$ & - & 200 & $10-60$ & $>100$ \\
\hline$\gamma_{n}\left(k N / m^{3}\right)$ & $14,7-17,1$ & 15 & $14,7-16,0$ & $14,5-15,6$ & 16 & $13,5-16,3$ & $15,0-16,3$ \\
\hline $\mathrm{C}_{\alpha c}(\%)$ & $3-6$ & $3-4,5$ (***) & - & $1,3-3,9$ & - & $3-6$ & - \\
\hline$C_{v}^{l a b}\left(\mathrm{~cm}^{2} / \mathrm{s}\right)$ & $(2-7) \cdot 10^{-4}$ & $(2-4) \cdot 10^{-4}$ & $1.10^{-4}$ & $(1-7) \cdot 10^{-4}$ & - & $(0,3-10) \cdot 10^{-4}$ & $(3-7) \cdot 10^{-4}$ \\
\hline$C_{v}{ }^{c a m p o} / C_{v}{ }^{l a b}$ & $10-20$ & 20 & $86 ?$ & - & - & $15-100$ & - \\
\hline$\delta\left(\mathrm{kN} / \mathrm{m}^{3}\right)$ & 26,5 & - & 26,5 & 26,8 & - & 26,6 & 26,0 \\
\hline$\%<5 \mu$ & $15-61$ & - & $40-80$ & - & $20-50$ & $20-90$ & $20-70$ \\
\hline LL & $47-137$ & $60-130$ & $50-87$ & - & $40-120$ & $40-150$ & $40-150$ \\
\hline IP & $19-87$ & $30-90$ & $31-46$ & - & $20-60$ & $20-90$ & $40-90$ \\
\hline IA & $0,9-2,9$ & - & - & - & 1,8 & $0,7-3$ & $0,8-2,0$ \\
\hline IL (\%) & $39-78$ & - & - & - & 55 & $50-160$ & $20-90$ \\
\hline$C_{d} /\left(1+e_{o}\right)$ & $(0,48)$ & $\begin{array}{c}0,25-0,44 \\
(0,35) \\
\end{array}$ & $0,26-0,31$ & $0,34-0,38$ & - & $\begin{array}{c}0,33-0,51 \\
(0,43) \\
\end{array}$ & $\begin{array}{c}0,35-0,43 \\
(0,39) \\
\end{array}$ \\
\hline $\mathrm{C}_{\mathrm{r}} / \mathrm{C}_{\mathrm{s}}(\%)$ & $(5)$ & - & $6-19$ & - & - & $8-12$ & 9 \\
\hline $\begin{array}{l}\bar{E}_{L} / \bar{\sigma}_{a} \\
(\mathrm{RSA}>1)\end{array}$ & 20 & - & - & - & - & $13-18$ & 11 \\
\hline
\end{tabular}

Legenda:

(1) Machado (1961); (2) Teixeira (1960-b e 1994);

(3) Gonçalves e Oliveira (2002); (4) Teixeira (1960-a)

De uma maneira simplificada, a análise da tabela I acima, mostra que as argilas apresentam valores semelhantes de acordo com a sua classificação. Exceção é feita para algumas propriedades de estado, como índice de vazios e resistência não drenada, de acordo com Massad (2003). Isso é devido as argilas de SFL na cidade de Santos terem sido adensadas sob pressões de terra maiores. Nesse contexto, verifica - se também que a pressão de pré-adensamento desempenha papel decisivo quanto à classificação. 


\subsection{3 - Perfil geotécnico da cidade de Santos}

Sondagens de simples reconhecimento, executadas ao longo dos anos em conjunto com os estudos realizados, permitiram resumir o perfil da cidade de Santos bem como a ocorrência das camadas, que se passa a descrever:

Às vezes, sob pequenas camadas de aterro, encontra-se areia medianamente compacta com espessuras entre 6 e $20 \mathrm{~m}$, com predominância entre 10 e $15 \mathrm{~m}$, SPT variando de 9 a 30 .

Logo abaixo ocorrem camadas de argila muito mole, que foram classificadas por Massad, (1985) como sendo Argilas de SFL, com profundidades entre 10 e 30m e valores de SPT entre 0 e 4.

Em profundidade, reencontramos camada de areia de compacidade variável Abaixo dos $20-25 \mathrm{~m}$ de profundidade, são encontradas as Argilas transicionais (A.T), também definidas por Massad (1985). São argilas de consistência média a rija, apresentam valores de SPT superior a 5 golpes.

Abaixo das argilas transicionais é possivel encontrar camadas de areia compacta e/ou sedimentos continentais. Em profundidade encontra-se o solo residual.

Nas margens e fundos de canais da rede de drenagem, se encontram ainda os Mangues, que são diferentes dos SFI; tratam-se de sedimentos mais recentes, caracterizados como sedimentos tipo vasa (lama), e apresentam valores de SPT $=0$. A tabela II elaborada por Massad (2003), apresenta uma síntese das diferenças entre as propriedades geotécnicas das Argilas Marinhas da Baixada Santista. Os dados apresentados foram obtidos através da realização de ensaios do cone (CPTU) e SPT-T. 
Tabela II - Síntese das diferenças das propriedades geotécnicas das argilas marinhas da Baixada Santista (Massad, 2003)

\begin{tabular}{|c|c|c|c|c|}
\hline & CARACTERISTICAS & MANGUE & SFL & AT \\
\hline \multirow{15}{*}{$\begin{array}{l}\mathrm{D} \\
\mathrm{I} \\
\mathrm{F} \\
\mathrm{E} \\
\mathrm{R} \\
\mathrm{E} \\
\mathrm{N} \\
\mathrm{C} \\
\mathrm{A} \\
\mathrm{S}\end{array}$} & PROFUNDIDADE (m) & $\leq 5$ & $\leq 50$ & $20 \leq z \leq 45$ \\
\hline & $\mathrm{e}$ & $>4$ & $2-4$ & $<2$ \\
\hline & $\bar{\sigma}_{a}(\mathrm{kPa})$ & $<30$ & $30-200$ & $200-700$ \\
\hline & RSA & 1 & $1,1-2,5$ & $>2,5$ \\
\hline & SPT & 0 & $0-4$ & $5-25$ \\
\hline & $\mathrm{s}_{\mathrm{u}}(\mathrm{kPa})$ & 3 & $10-60$ & $>100$ \\
\hline & $\gamma_{n}\left(\mathrm{kN} / \mathrm{m}^{3}\right)$ & 13,0 & $13,5-16,3$ & $15,0-16,3$ \\
\hline & ARGILO-MINERAIS & $\mathrm{K} / \mathrm{I}$ & $\mathrm{K} / \mathrm{M} / \mathrm{I}$ & $\mathrm{K} / \mathrm{I}$ \\
\hline & MATÉRIA ORGÂNICA & $25 \%$ & $6 \%(1)$ & $4 \%(1)$ \\
\hline & SENSITIVIDADE & - & $4-5$ & - \\
\hline & $\phi^{\prime}(1) \mathrm{e}(2)$ & - & 24 & 19 \\
\hline & $\mathrm{C}_{\alpha \varepsilon}(\%)$ & - & $3-6$ & - \\
\hline & $C_{v}^{l a b}\left(\mathrm{~cm}^{2} / \mathrm{s}\right)(3)$ & $(0,4-400) \cdot 10^{-4}$ & $(0,3-10) \cdot 10^{-4}$ & $(3-7) \cdot 10^{-4}$ \\
\hline & $C_{v}^{c a m p o} / C_{v}^{l a b}$ & - & $15-100$ & - \\
\hline & ADESÃO EM ESTACAS (kPa) & - & $20-30$ & $60-80$ \\
\hline
\end{tabular}

\subsection{4 - Ação de dunas}

Massad (2006, 2008), mostrou várias evidências da ação de dunas na Baixada Santista, destacando que elas podem ser de ordem histórica, geográfica e geotécnica.

De acordo com Massad (2006), uma confirmação histórica da presença de dunas no tempo da colonização, é o "Mapa da Ilhas de São Vicente e Santo Amaro, Século XVII", de autor português, reproduzida por Ab'saber (2005). Este mapa mostra nitidamente a orla praiana de Santos coberta por dunas.

Do ponto de vista geotécnico, as evidências de dunas referem-se: a) aos valores mais elevados de SPT; b) ao pré-adensamento das argilas; c) ao comportamento de aterros e edifícios construídos sobre solos moles.

Autores como Suguio, Martin e Rodrigues, citados por Massad (2006), mencionaram a ocorrência de dunas em Praia Grande, Guarujá e São Vicente, com alturas de 1,0 a 5,0m. Em Santos, sabe-se da existência de dunas na Ponta da Praia, na entrada do canal do porto, onde no início do século XX existia o Forte Augusto (foto 04), e hoje está localizado o Museu de Pesca (fotos 05 e 06) 


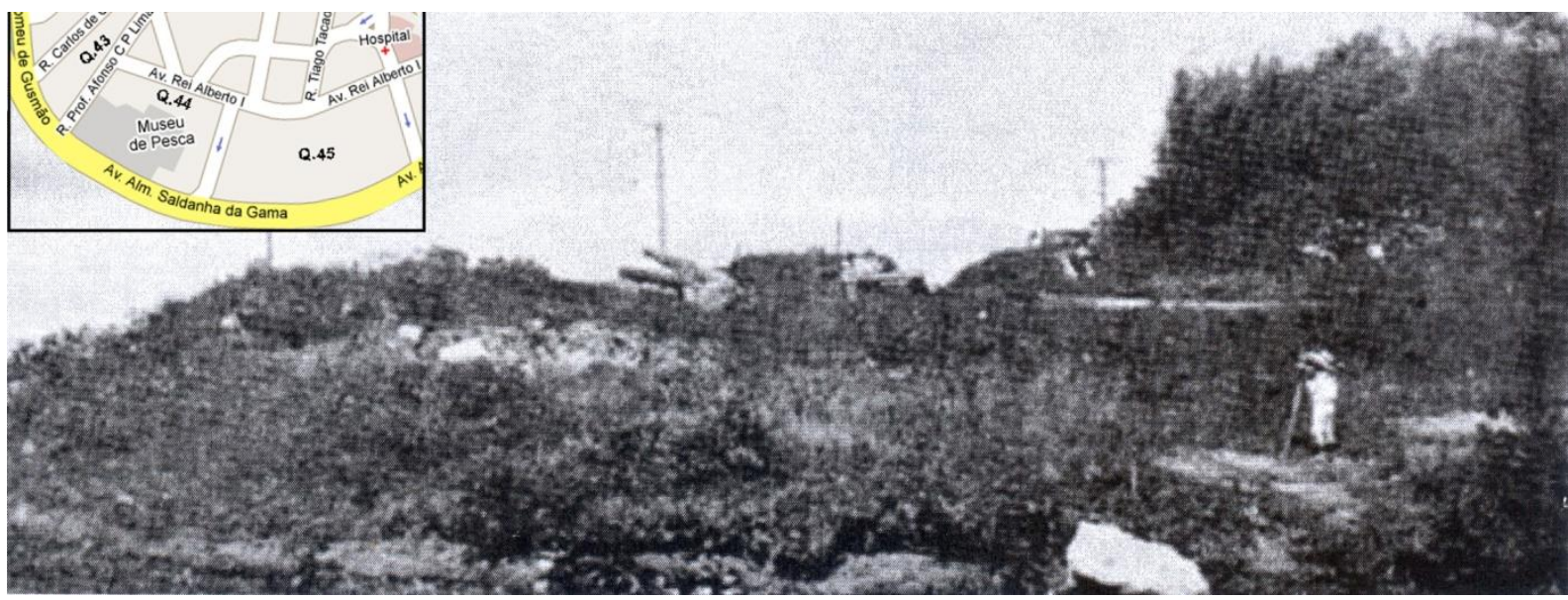

Foto 04 - Antiga duna existente na Ponta da Praia, início do Sec. XX (Fonte: Adaptada de http://www.novomilenio.inf.br, jul, 2008- Foto publicada no Diário Ofical de Santos de 1972)

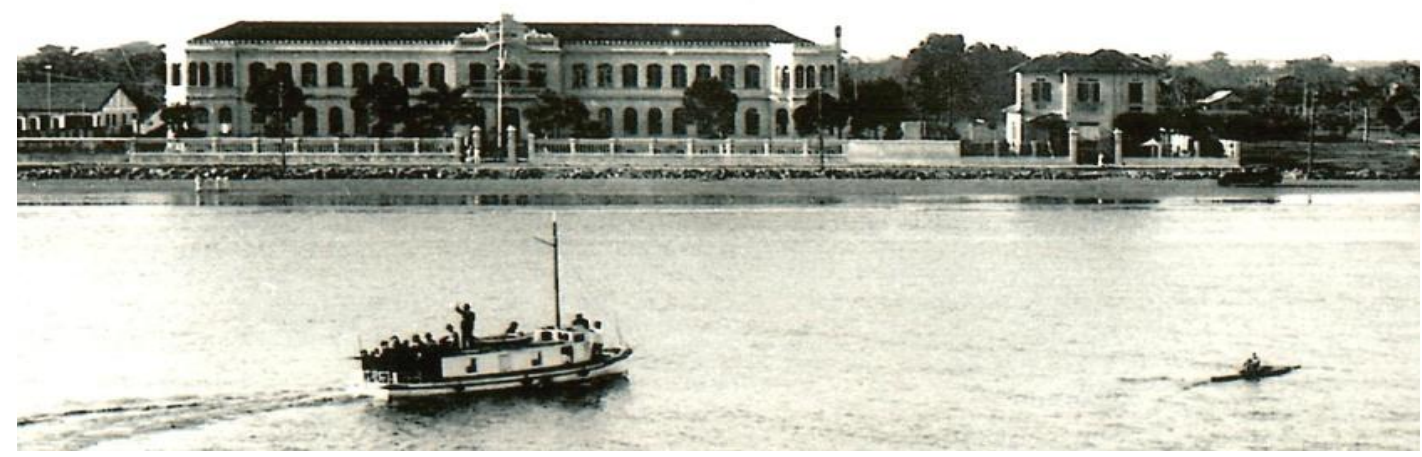

Foto 05 - Museu de Pesca por volta dos anos 40 (Fonte: Ary Célio - contato pessoal) 


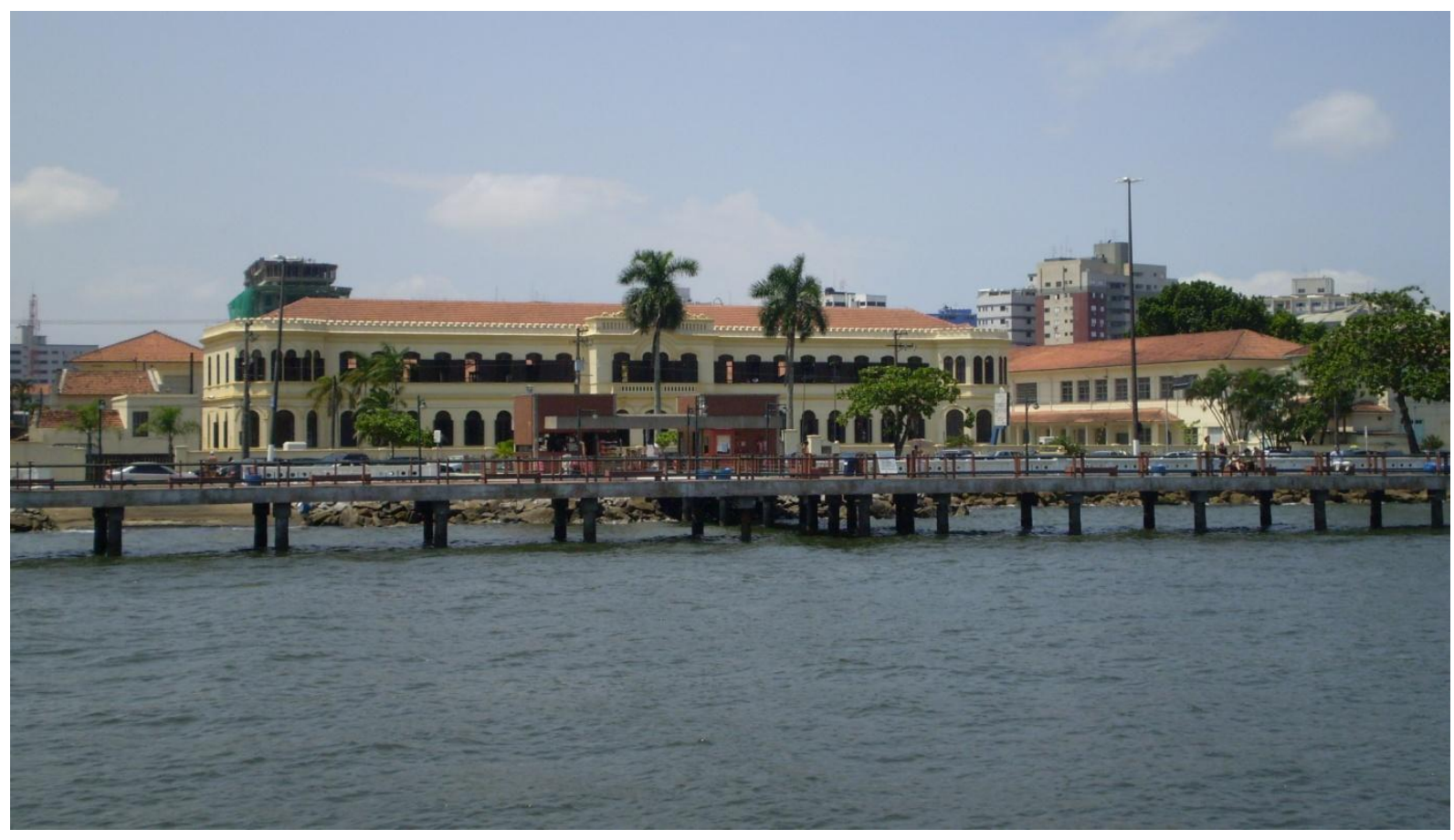

Foto 06 - Museu de Pesca hoje, após a restauração.

No presente trabalho, foi feito uma pesquisa nos arquivos históricos da cidade de Santos, para tentar obter mais dados sobre a ocorrência de Dunas no passado.

Foram consultados os seguintes locais nos quais poderiam ser encontrados fotos ou relatos sobre dunas: Fundação Arquivo e Memória de Santos, onde estão arquivados uma enorme quantidade de fotos da cidade, desde os tempos da colonização; jornais com matérias antigas da cidade; o Instituto Histórico e geográfico de Santos; Museu do Porto; Pinacoteca Benedito Calixto, além de busca na internet por fotos, mapas e cartas náuticas. Por último, ainda, historiadores e fotógrafos antigos da cidade também foram procurados.

Não foram encontradas fotos de dunas, mas há relatos de que em Santos existiram o que popularmente os moradores chamavam de "jundus"; esses "jundus" podiam elevar-se sobre dunas de areia com 3,0 a 4,0 metros de altura. Aqui cabe uma explicação técnica ao termo "jundu". Trata-se de "uma espécie nativa de áreas litorâneas, que cresce em solo arenoso, suporta fatores como a salinidade, ventos e insolação forte; o jundu tem o importantíssimo papel de fixar areia e dunas, impedindo a erosão das praias, pela ação dos ventos e das ondas." (Dicionário. Pro Disponível em: http://www.dicionario.pro.br/dicionario) 


\subsection{5 - Influência das dunas nos recalques dos edifícios}

Dunas que ocorreram no passado tiveram um papel muito importante se confrontado com os problemas de recalques de hoje. Tomando como exemplo uma duna de $5,0 \mathrm{~m}$ de altura, supondo que ela tenha ficado estacionada no mesmo local por um longo tempo, a máxima pressão exercida por ela equivale a um edifício de nove andares; mesmo após a sua remoção essa pressão ficaria registrada na argila. Dunas com 3,0 a 4,0m de altura equivaleriam ao peso de edifícios de 6 a 7 andares. Massad (2006, 2008-a, 2008-b) explicou que o desaprumo de alguns edifícios de Santos pode ser atribuído a tensão não uniforme que as dunas exerceram no subsolo, face a sua altura variável. Dessa maneira entende-se como certos edifícios inclinaram para um lado, sem ter influência de prédios vizinhos. A figura 10 representa essa inclinação.

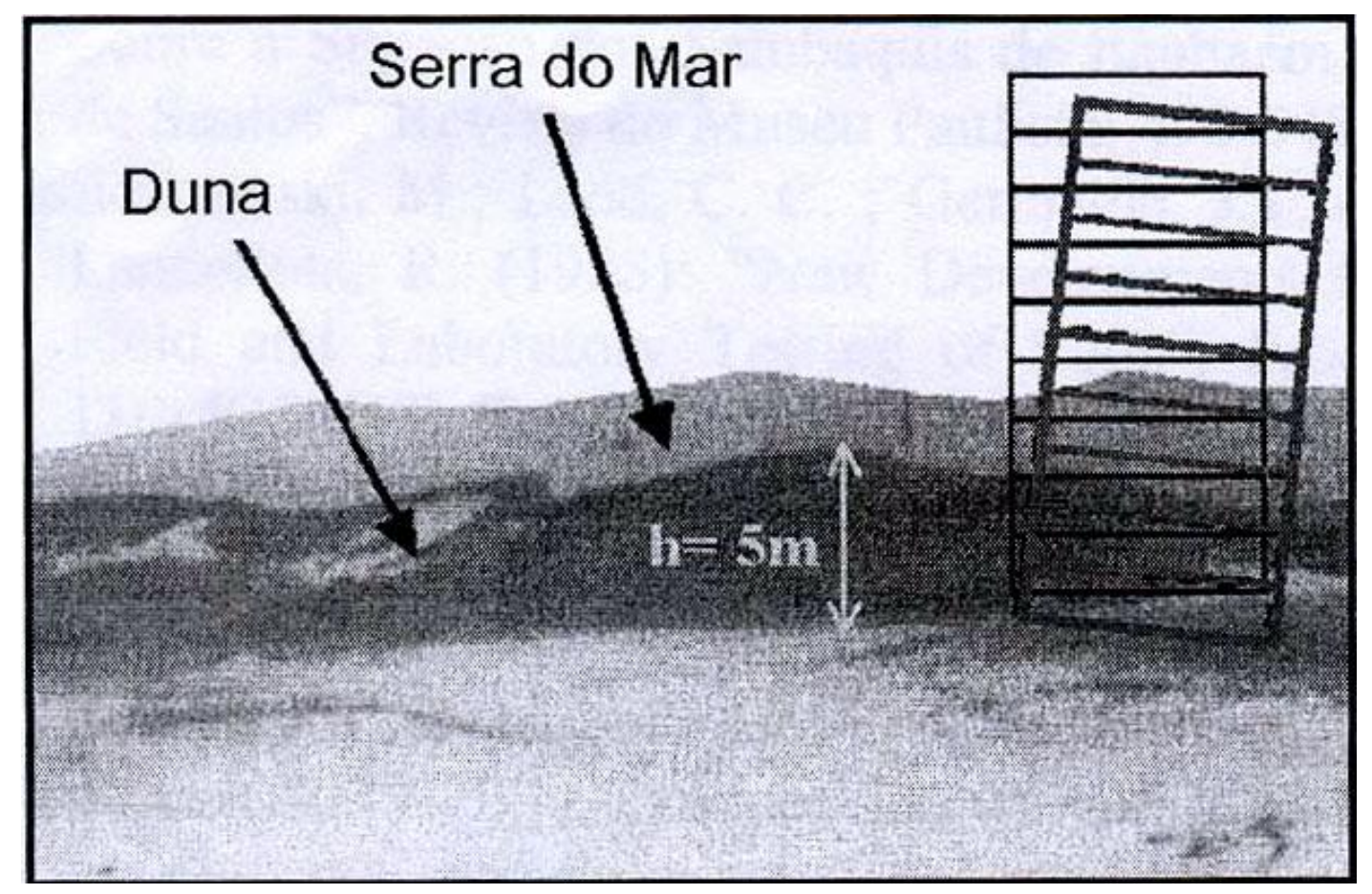

Figura 10 - Esquema da construção de um edifício onde antes existia uma duna (Fonte: Adaptado de Rodrigues, 1965 por Massad, 2004). 


\section{4 - OS RECALQUES E AS FUNDAÇÕES DOS EDIFÍCIOS}

\subsection{1 - Adoção de fundações rasas}

Durante o período de 1940-1970, Santos esteve em constante crescimento imobiliário, onde praticamente toda orla santista foi tomada por grandes construções.

Conforme já mencionado nesse trabalho, o fato de o solo de Santos possuir uma primeira camada de areia medianamente compacta, levou os construtores na década de 40, início da ocupação da orla praiana, a executar edifícios de 10 pavimentos ou mais em fundação direta.

De acordo com Teixeira (1994), por volta dos anos 50, já era de pleno conhecimento que as edificações, implantadas em fundação direta, poderiam sofrer recalques devido à presença de camadas de argila marinha muito compressíveis. Com o objetivo de diminuir recalques diferenciais, as sapatas eram interligados por vigas de rigidez.

$\mathrm{Na}$ época, havia limitações em termos de fundações profundas: o que se tinha disponível no mercado eram apenas estacas pré-moldadas, estacas Franki e tubulões pneumáticos, soluções tecnicamente inviáveis para o solo de Santos, por não conseguirem atravessar a primeira camada de areia compacta. Mesmo quando se contou com recursos técnicos para execução de estacas através de camadas de areias compactas, podendo chegar a mais de $30 \mathrm{~m}$ de profundidade, os empreendedores imobiliários julgaram o uso dessas fundações economicamente inviáveis (Teixeira, 1994)

\subsection{2 - Recalques: um problema técnico}

Ao longo dos anos, não só o tamanho dos edifícios aumentou bem como a quantidade. Isso gerou um aumento nas tensões transferidas às camadas compressíveis e também a interferência dos bulbos de tensão das construções vizinhas, agravando ainda mais a situação dos edifícios.

A densificação e construção de edifícios muito próximos desencadearam uma série de processos e polêmicas judiciais relativas aos recalques mútuos ou recíprocos e os conseqüentes desaprumos das estruturas (Teixeira, 1994). Um exemplo disso 
está retratado na foto 07 , onde o edifício Mahembi, inclinou-se em direção ao edifício vizinho, edifício Paineiras, após sua construção.

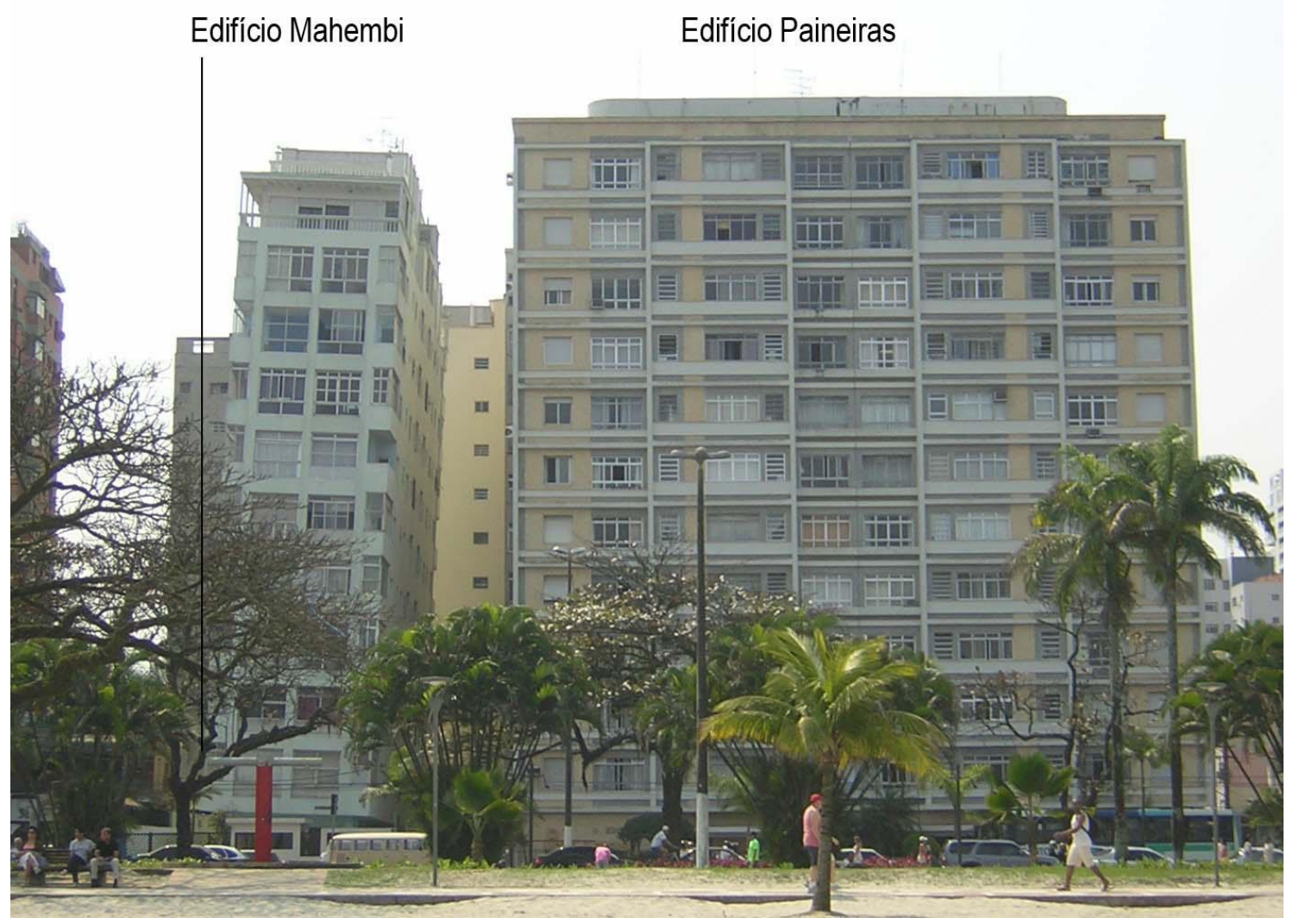

Foto 07 - Edifício Maembi a esquerda da foto, inclinado em direção ao edifício Paineiras, à direita

Conforme relatado por Teixeira (1994), com o intuito de minimizar as conseqüências dos recalques na orla de Santos, tentou-se alertar as autoridades competentes a limitar em dez, o número de pavimentos dos edifícios apoiados em fundação direta, mas em contradição com o que foi estipulado, a especulação do mercado imobiliário elevou o número de pavimentos para 18.

Em 1965, uma série de palestras foram apresentadas no Instituto de Engenharia para discutir o problema de fundações em Santos. Como resultado das discussões dois documentos foram gerados: "Para uma Orientação ao Projeto da Estrutura de Fundação de Obras na Baixada Santista" (1965) e "Recomendações à Prefeitura Municipal de Santos” (1965). Nesses documentos foi descrita uma série de 
recomendações e restrições quanto ao emprego de fundação direta na Orla da Santos.

Desde o aparecimento dos primeiros problemas de recalque nas construções de Santos, se fez necessário acompanhar a velocidade de recalques das edificações. Valores de medições de recalques de diversos edifícios foram relatados por Teixeira (1960), Machado (1954, 1958) e mais recentemente por Cardoso (2002). Além dos valores absolutos e diferenciais o adensamento secundário já preocupava os engenheiros da época, Vargas (1965) destacou:

os recalques observados em Santos correspondem em geral aqueles calculados pela teoria de Terzaghi. Mas há casos em que eles continuaram progredindo, ultrapassando os valores previstos. Isso demonstra a existência, nos solos santista, do que se chama compressibilidade secundária.

Talvez um fator agravante em Santos, tenha sido admitir valores de recalques muito mais altos do que em qualquer outro lugar no mundo, salvo algumas exceções, como na cidade do México. Se por exemplo $10 \mathrm{~cm}$ de recalque fosse estipulado como valor absurdo, a obra, nessas condições não poderia ser executada.

\subsection{3 - Recalques: um problema social}

Além do péssimo aspecto visual, os recalques diferenciais excessivos acarretam na má funcionalidade dos edifícios. De acordo com Teixeira (1994) o desaprumo das estruturas gera uma série de problemas tais como:

a) desnivelamento dos pisos de todos os pavimentos; dessa forma dependendo do sentido desse desnivelamento e da posição dos ralos, a água não mais escorre para os mesmos, sendo necessário refazer o caimento dos pisos para a correção do problema;

b) perda das prumadas guia dos elevadores, dificultando sua operação;

c) deformação das paredes de alvenaria, caixilhos e batentes das portas, obrigando o acerto dos mesmos;

d) fissuramento nas alvenarias e nos revestimentos. 
O fato é que a inclinação dos edifícios de Santos deixou de ser um problema somente de engenharia de fundações e estruturas. Passou a ser também um problema social que importuna diariamente a vida dos proprietários e moradores desses edifícios.

Além dos inconvenientes relatados, os grandes desaprumos acarretam problemas de ordem financeira, fazendo com que esses edifícios sofram uma enorme desvalorização, o que tem ocorrido ao longo dos anos.

Para se ter uma idéia do tamanho dessa desvalorização, pode-se tomar como exemplo o edifício Núncio Malzone, que será detalhado mais adiante. Ele é composto por dois blocos, sendo que o da frente possui um apartamento por andar. Antes de o edifico ser recuperado, uma unidade desse bloco foi vendida por $R \$$ $36.000,00$ sendo que o valor de mercado para um imóvel desse porte, de frente para a praia, seria de $R \$ 300.000,00$ a $400.000,00$

O trabalho do arquiteto Nunes (2003), mostrou que a maioria dos apartamentos de pequeno porte ao longo da orla de Santos, com problemas significativos de recalque, são ocupados por idosos e solteiros que possuem renda mensal nominal abaixo de 10 salários mínimos. Nunes (2003) também constatou que a inadimplência no pagamento do condômino mensal, que varia de $R \$ 180,00$ a $R \$$ 220,00 , é muito alta, dificultando ainda mais a possibilidade de se arrecadar dinheiro para futuras obras de recuperação dos mesmos.

\subsection{4 - $O$ uso atual de fundações profundas}

Como já dito no item 2.4.1 do presente trabalho, no início da ocupação da orla de Santos, o emprego de fundações profundas era inviável devido ao custo muito alto. Hoje, com o custo reduzido, desenvolvimento de novas técnicas e maior conhecimento dos problemas que ocorrem quando edifícios são apoiados em fundação direta, a maioria dos novos empreendimentos são realizados com emprego de fundações profundas.

Como as fundações devem atravessar as camadas de argila mole (SFL e AT) para atingir o solo resistente, não é qualquer equipamento que consegue realizar o procedimento com eficácia. Atualmente, as soluções mais utilizadas em Santos são: a) estacas escavadas de grande diâmetro com uso de lama bentonítica ou polímero, 
b) perfil metálico com uso de martelo hidráulico, para diminuir a vibração no terreno, c) estacas raiz.

Em alguns casos ainda, quando a edificação não é muito alta, 16 pavimentos por exemplo, as cargas transmitidas ao terreno são de menor porte. Pode-se utilizar então, "estacas flutuantes", apoiadas na segunda camada de areia, por volta de 20$30 \mathrm{~m}$ de profundidade; nesse caso pode-se utilizar estacas pré-moldadas ou estacas hélice.

\section{5 - TÉCNICAS DESENVOLVIDAS PARA A ESTABILIZAÇÃO DOS RECALQUES}

Devido a uma série de edifícios desaprumados, o trabalho dos engenheiros e pesquisadores ganhou outro foco: estudar e propor soluções para estabilização dos recalques e nivelamento dos edifícios. No decorrer dos anos surgiram muitas idéias e propostas, mas é importante lembrar que a melhor solução é aquela que seja não só eficiente, de "fácil" execução, mas que tenha um custo acessível para que os moradores tenham condições de executar a obra, caso contrário, torna - se apenas mais uma idéia não aplicada.

Em Santos alguns edifícios foram submetidos a obras de recuperação com o objetivo de estabilizá-los. Certos casos foram bem sucedidos, outros só obtiveram sucesso na segunda tentativa, com aplicação de outra metodologia; há ainda aqueles que não tiveram resultados, ou seja, continuaram a inclinar mesmo após a intervenção.

A seguir serão relatados alguns métodos desenvolvidos para estabilização de recalques e algumas aplicações.

\subsection{1 - Sangria de areia sob sapatas}

Esta técnica consiste basicamente em retirar areia sob as sapatas do lado menos recalcado, objetivando o reaprumo do edifício. É um método mais econômico, mas em geral não apresenta bons resultados. “(...) É necessário que a remoção de material em cada elemento de área seja proporcional ao recalque que se pretende impor a fim de se induzir um movimento de corpo rígido da estrutura (...)" (Maffei, et al., 2003). 
O edifício Morená localizado na orla de Santos próximo ao canal 3 começou a ser construído em 1965. Durante o período das obras, a construtora foi alertada que recalques diferencias de até $90 \mathrm{~cm}$ poderiam ocorrer, em função do edifício vizinho que seria construído algum tempo depois. Na ocasião foi sugerido deixar furos nas sapatas para facilitar a execução futura de sangrias, com o intuito de diminuir os recalques futuros.

Em 1969, foi iniciada a construção do edifício vizinho de 17 pavimentos e em julho de 1971, seis meses após o edifício Morená ter sido entregue, ocorreu esmagamento de dois pilares. Na tentativa de estabilizar seus recalques, foram executadas sangrias em duas etapas. Na primeira etapa, retirou-se $27.300 \mathrm{~kg}$ de areia e na segunda $12.000 \mathrm{~kg}$. Isso foi equivalente a um peso total de material extraído sob as sapatas de 40 tf.

Como os recalques totais continuaram a ocorrer em grande velocidade, as sangrias foram suspendidas. Posteriormente, durante a execução de um novo projeto de recuperação, foram feitas escavações para verificar a situação das sapatas e constatou-se a existência de grandes vazios debaixo de todas as sapatas que sofreram sangria.

De acordo com Gerber, et al.(1975), imediatamente os vazios foram preenchidos com concreto e injeção de argamassa. Verificou-se que o volume de argamassa e concreto utilizados para preencher os vazios, foram bem próximos ao volume de areia retirado nas sangrias. Isso comprova que as sapatas não recalcaram com a extração de areia, ficando suspensas; a estabilidade do prédio nessa fase foi garantida pela rigidez da estrutura.

Gerber, et al.(1975), destaca que em algumas sapatas foi possível entrar e passar abaixo do fundo das mesmas.

\subsection{2 - Carregamento do lado menos recalcado}

Simplesmente uma carga é aplicada no lado menos recalcado do edifício, a fim de que esse lado sofra recalque, igualando-se ao lado oposto. Esse método foi julgado pouco eficiente. De acordo com Maffei, et al. (2003), o fato de a argila recalcar e da camada superior de areia acompanhar esse movimento, não implica que o prédio também o fará. 
O edifício Excelsior também conhecido na cidade como "o torto", devido a um bar com esse nome instalado na área comercial do condomínio, foi construído ao lado do canal 4 no final dos anos 60 . A edificação tem um formato em "L" e é composta por duas torres de 18 pavimentos. Uma torre foi destinada aos apartamentos, a outra, um edifício só de garagens que por meio de elevadores transportariam os automóveis. Devido aos grandes recalques sofridos logo após a construção do edifício de garagens, a instalação dos elevadores que transportariam os automóveis foi inviabilizada, dessa forma até os dias de hoje o edifício de garagens nunca pode operar.

Por volta de 1977, o edifício Excelsior tinha um recalque diferencial de 0,94m, segundo laudo do IPT realizado na época (Gonçalves, 2004). Isso fez com que engenheiros da Prefeitura Municipal de Santos interditassem o edifício em junho do mesmo ano. Tentar estabilizar os recalques era mais do que necessário.

Como primeira tentativa, foi colocado uma sobrecarga temporária de $20000 \mathrm{kN}$ do lado menos recalcado do edifício. A sobrecarga não obteve resultado. Uma possível explicação para o fato foi dada anos depois por Massad $(2006,2008)$, citado no item 2.3.3 do presente trabalho, onde destacou-se que a ação de dunas pode ser responsável pelo sobreadensamento errático das argilas de Santos.

\subsection{3 - Injeções para expandir o solo}

Injeções de argamassa são aplicadas no maciço com o objetivo de provocar um levantamento controlado do edifício. Como exemplo tem-se a recuperação do Palácio de Belas Artes na cidade do México.

Este Palácio foi construído por volta de 1906, sobre fundação direta. Em 1909 o recalque diferencial entre os lados nordeste e sudoeste alcançou $27,2 \mathrm{~cm}$. Essa situação levou engenheiros e arquitetos da época a optarem por recuperar o edifício injetando argamassa no solo mole.

"Um tubo de 9,0m de comprimento e 2 1/2" de diâmetro foi introduzido no subsolo a $5,0 \mathrm{~m}$ de profundidade, por um martelo de $300 \mathrm{~kg}$, para a execução das injeções de argamassa. A argamassa foi injetada com pressões da ordem de $200 \mathrm{kPa}$. 
Inicialmente $4.388 \mathrm{~m}^{3}$ de argamassa foram aplicadas na recuperação do palácio em campanhas sucessivas, durante, 1910, 1912 e 1913. Em 1921, mais 99m3 de argamassa foi injetado e entre 1924 e 1925 foram aplicadas mais $4.600 \mathrm{~m}^{3}$.

De 1910 a 1925, analisando os pilares extremos do palácio, pode-se observar que o pilar 191 do lado noroeste, em 1901 apresentava velocidade de recalque de 42,9 $\mathrm{cm} / \mathrm{ano}$, enquanto que no pilar 14 , do lado oposto, a velocidade era $15,7 \mathrm{~cm} / \mathrm{ano}$; diferença de 27,2 cm/ano (figura 11). Depois do início das injeções de argamassa, a velocidade dos recalques foram diminuindo progressivamente. De acordo com Santoyo e Shelley (2003) o método apresentou resultados satisfatórios pois, embora os recalques totais não tenham sido interrompidos, eles se tornaram uniforme.

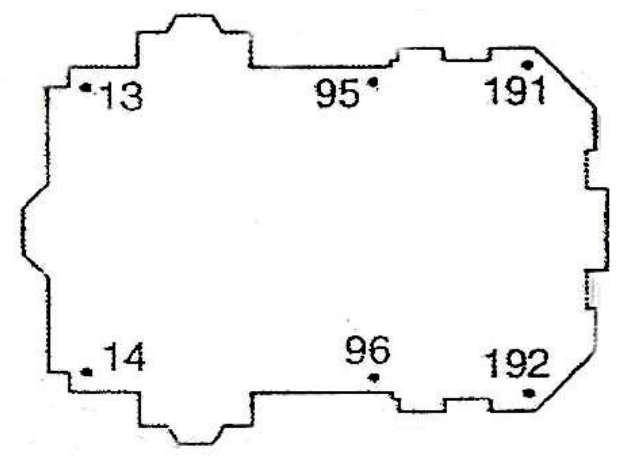

Figura 11 -Locação dos pilares extremos do Palácios de Belas Artes (Fonte: Santoyo e Shelley, 2003)

$\mathrm{Na}$ cidade do México diversos edifícios foram submetidos a essa técnica para estabilização de recalques. Em alguns casos, as injeções foram usadas para diminuir as inclinações dos edifícios, em complemento de outras ações, como a retirada de solo mole por exemplo, para garantir a estabilidade da edificação. O trabalho de Santoyo e Sheller (2003), apresenta diversas obras recuperadas com o emprego de injeções de argamassa, mostrando que em todos os casos as injeções modificaram o comportamento das estruturas favoravelmente.

\subsection{4 - Sistema cisalhante de Ranzini}

Essa proposta de autoria de Ranzini (2001 e 2003), baseia-se na possibilidade de modificar a distribuição de tensões no interior dos solos. Se o meio é contínuo, há distribuição de tensões (espraiamento da carga); se o meio é descontínuo, não há espraiamento das tensões. 
De acordo com o autor, quando uma carga é aplicada num ponto da superfície livre do maciço, são geradas tensões de cisalhamento que se "espraiam" lateralmente, diminuindo com a profundidade (figura 12-a). Se no interior do maciço a resistência ao cisalhamento for anulada em planos verticais, como ilustra a figura 12-b o espraiamento das tensões verticais fica impedido, resultando uma concentração dessas tensões.

Em Santos, a técnica proposta por Ranzini para reaprumar edificações pode ser aplicada criando-se um plano vertical na camada de argila mole, de resistência ao cisalhamento nula, junto à face menos recalcada, com o intuito de provocar uma concentração de tensões em profundidade, revertendo a tendência de inclinação dos edifícios. Quanto a aplicação do método de Ranzini existe a dificuldade de se criar o plano vertical de resistência nula ao cisalhamento.

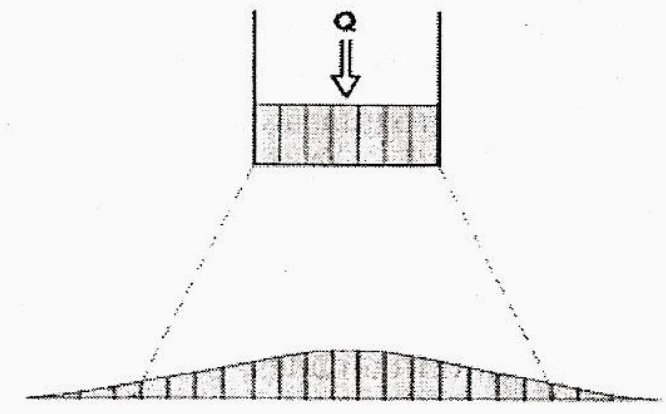

a

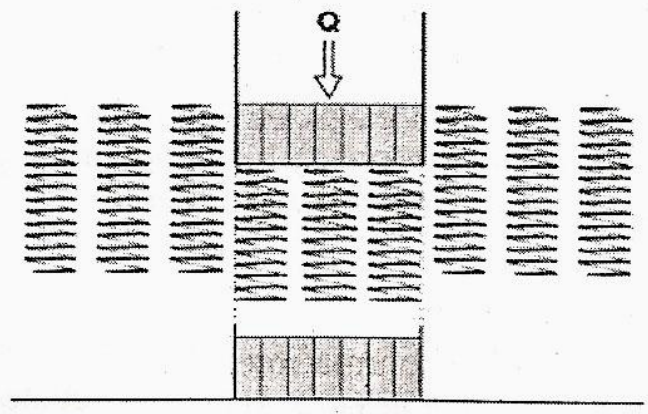

b

Figura 12 - Esquema representativo do método de Ranzini. A figura do lado esquerdo representa o meio contínuo e, a do lado direito, representa o meio descontínuo (Fonte: Ranzini, 2003)

\subsection{5 - Reforço da fundação com emprego de estacas profundas}

Existem diversas maneiras de se aplicar esse método, mas o objetivo principal é executar estacas profundas que ultrapassem a camada de solo mole, e por meio de vigas, interligá-las ao edifício para transferir as cargas à nova fundação.

Pode-se incorporar as estacas à fundação direta existente, ou proceder como no edifício Núncio Malzoni, onde as sapatas existentes foram completamente desativadas, e a transferência de carga para a nova fundação, se fez por vigas de travamento passando por toda extensão do edifício, no sentido transversal a ele. 


\section{a) $O$ caso do edifício Núncio Malzoni}

O edifício Núncio Malzoni construído em 1967, é composto por dois blocos (A e B) de 17 andares, com $55 \mathrm{~m}$ de altura; possui fundação em sapatas, apoiadas entre 1,5 $\mathrm{m}$ e 2,0 $\mathrm{m}$ de profundidade, interligadas por vigas de rigidez.

Em 1978 houve a primeira tentativa de diminuir os recalques diferencias. Foram executadas estacas raiz, com $25 \mathrm{~cm}$ de diâmetro e $50 \mathrm{~m}$ de profundidade, em todas as sapatas do lado mais recalcado.

Logo após a execução do reforço, houve diminuição dos recalques, mas meses depois eles voltaram a ocorrer com velocidades parecidas às anteriores, entre 8 $\mathrm{mm} / \mathrm{ano}$ e $13 \mathrm{~mm} / \mathrm{ano}$ (Maffei et al, 2003).

O bloco A do edifício Núncio Malzoni chegou a apresentar uma inclinação de 2,2 graus para o lado esquerdo e 0,6 graus em direção ao bloco $B$, fundo do edifício (Maffei et al, 2000).

Depois de estudar muitas propostas de solução e analisar a relação custo-benefício, os moradores optaram pelo projeto desenvolvido pela Carlos E.M. Maffei engenharia que propôs não só estabilizar os recalques, mas também reaprumar o edifício. A execução da obra exigiu muito cuidado, pois todo o processo ocorreu sem que os moradores desocupassem os imóveis. Pode-se sintetizar a obra em quatro etapas:

$1^{\text {a }}$ etapa: Foram executadas 16 estacas escavadas (estacões), de cada lado do edifício com uma profundidade média de $55 \mathrm{~m}$ e diâmetros variando de $1,0 \mathrm{~m}$ a 1,40 $\mathrm{m}$. Os estacões começaram a ser executados do lado menos recalcado do edifício.

$2^{a}$ etapa: Execução das vigas de transição. Foram sete vigas principais tipo virandeel, com cerca de 4,5 m de altura para receber os esforços dos pilares e transmiti-los às novas fundações. A primeira viga a ser executada foi a da frente; as outras foram concretadas de maneira intercalada. As vigas secundárias, longitudinais foram executadas após o termino das principais.

$3^{\text {a }}$ etapa: Foram utilizados 14 macacos hidráulicos acionados por seis bombas, instalados entre as vigas de transição e os novos blocos de fundação, para reaprumar o edifício. Dos dois lados de cada macaco foram construídos pilaretes para a colocação dos calços, que além de garantir a segurança do prédio, serviram de apoio para as vigas enquanto o curso de cada macaco era abaixado. Isso foi 
necessário porque o curso dos macacos variava entre $5 \mathrm{~cm}$ e $15 \mathrm{~cm}$ e o prédio foi levantado em até $80 \mathrm{~cm}$ junto ao último pilar do lado esquerdo do edifício.

$4{ }^{\text {a }}$ etapa: Após os macacos terem sido colocados em carga, foi feita a escavação do terreno, para que as sapatas ficassem totalmente livres, sem contato com o terreno.

Reaprumado, hoje, o Núncio Malzoni transmite suas 6500 tf ao solo, por meio das estacas profundas.

Importante ressaltar que o reaprumo foi feito somente no Bloco $A$. No bloco $B$ foram executadas estacas raiz de $40 \mathrm{~cm}$ de diâmetro, com profundidade média de 55,0 m. Mas o macaqueamento do edifício não foi feito por falta de verba. As fotos 08(a) e 08(b) mostram o edifício antes e depois do reaprumo.

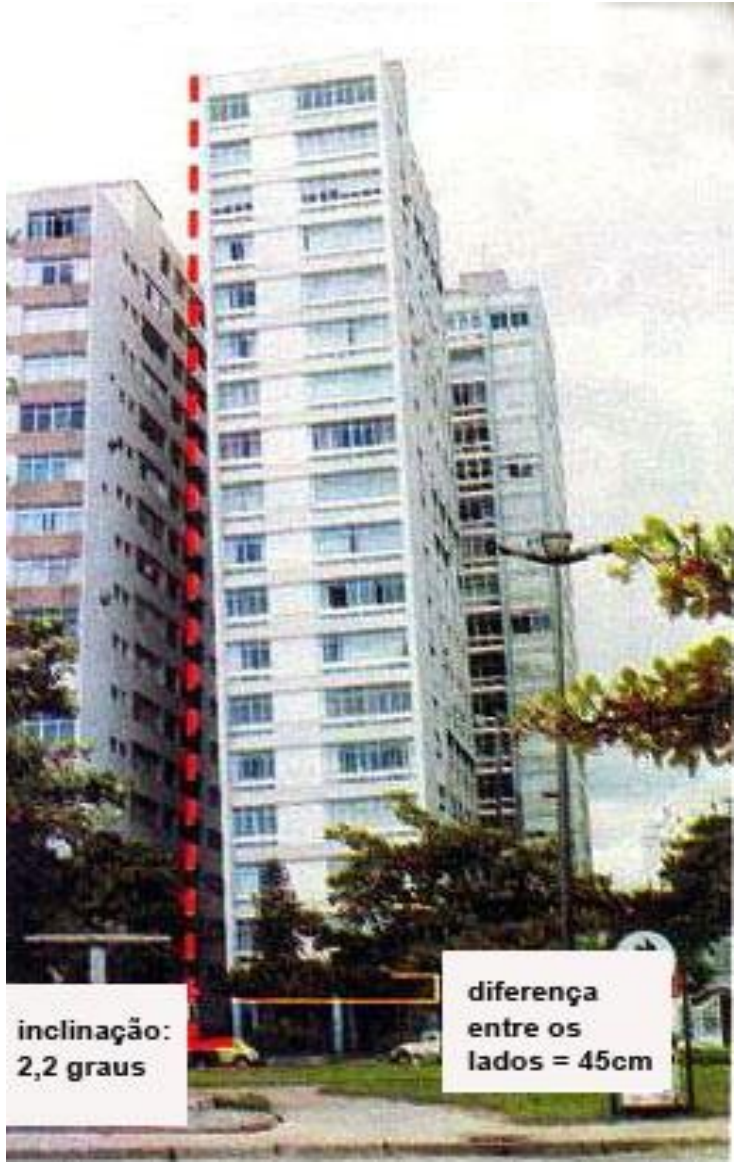

Foto 8(a) Edifício antes do reaprumo

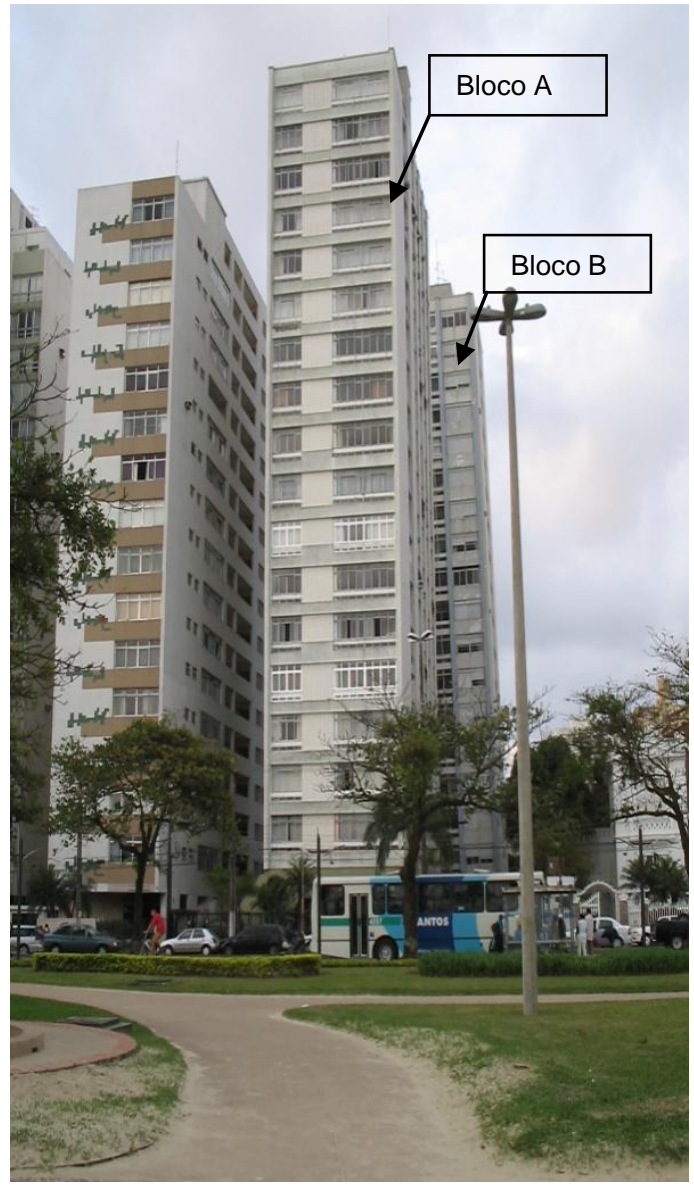

Foto 8(b) Edifício depois do reaprumo 


\section{b) $O$ caso do edifício Excelsior}

Conforme citado no item 2.5.2 do presente trabalho, a primeira tentativa de estabilizar os recalques do edifício foi feita com aplicação de sobrecarga do lado menos recalcado. Como a solução não obteve sucesso, optou-se por reforçar a fundação do prédio utilizando estacas raiz.

Foram executadas 52 estacas raiz com $55 \mathrm{~m}$ de comprimento e $15 \mathrm{~cm}$ de diâmetro, sob as sapatas mais recalcadas, na região da esquina. O projeto previa a execução de 104 estacas que seriam executadas em duas fases, mas como o recalque quase estabilizou logo após o término da primeira fase, prefeririam não continuar o reforço.

Medições de recalques foram feitas periodicamente. Foi constatado que, logo após a execução das estacas raiz, os recalques estabilizaram, mas algum tempo depois eles voltaram a ocorrer só que em proporções bem menores. De acordo com Gonçalves 2004, em novembro de 1992 a velocidade de recalques do edifício variava de 25 a $12 \mu /$ dia. A partir de 1993 as velocidades de recalques não foram mais divulgadas, por decisão dos moradores do edifício. A foto 09 retrata a situação atual do edifício Excelsior, inclinado para o lado do canal 04.

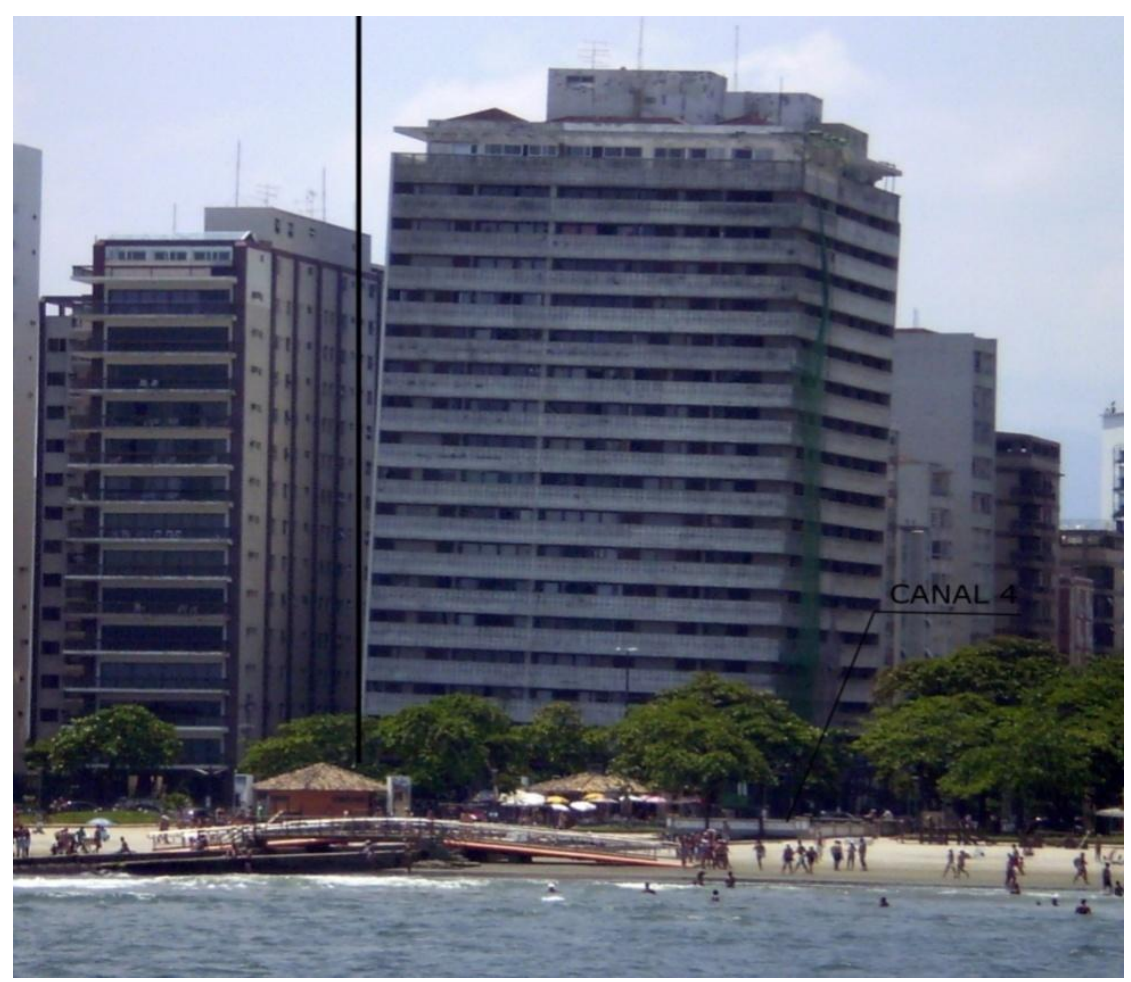

Foto 09 - Edifício Excelsior inclinado para o lado do canal 4 


\section{c) $O$ caso do edifício Morená}

De acordo com o item 2.5.1 do presente trabalho, foram executadas sangrias em duas etapas na tentativa de diminuir os recalques diferenciais do edifício. Como as sangrias não proporcionaram bons resultados, elaborou-se um novo projeto de recuperação.

A concepção do projeto foi transferir a carga dos pilares mais recalcados, junto à divisa com o prédio vizinho, para os pilares menos recalcados.

Foi cravada uma linha de 17 estacas metálicas $(\mathrm{H}-23 \times 23 \mathrm{~cm})$ com $55 \mathrm{~m}$ de profundidade, que serviram de apoio a um sistema de macacos, atuantes na extremidade de vigas alavancas, para transmitir a eles as cargas desejadas.

Medidas de recalques constataram que, a aplicação gradativa das cargas cessaram totalmente a evolução dos recalques e inverteram a tendência do desaprumo. Até maio de 1975, constatou - se um retorno de 3,3 e $6 \mathrm{~mm}$ nas três prumadas de controle do edifício. (Gerber et al., 1975). A foto 10 mostra ao situação atual do edifício Morená.

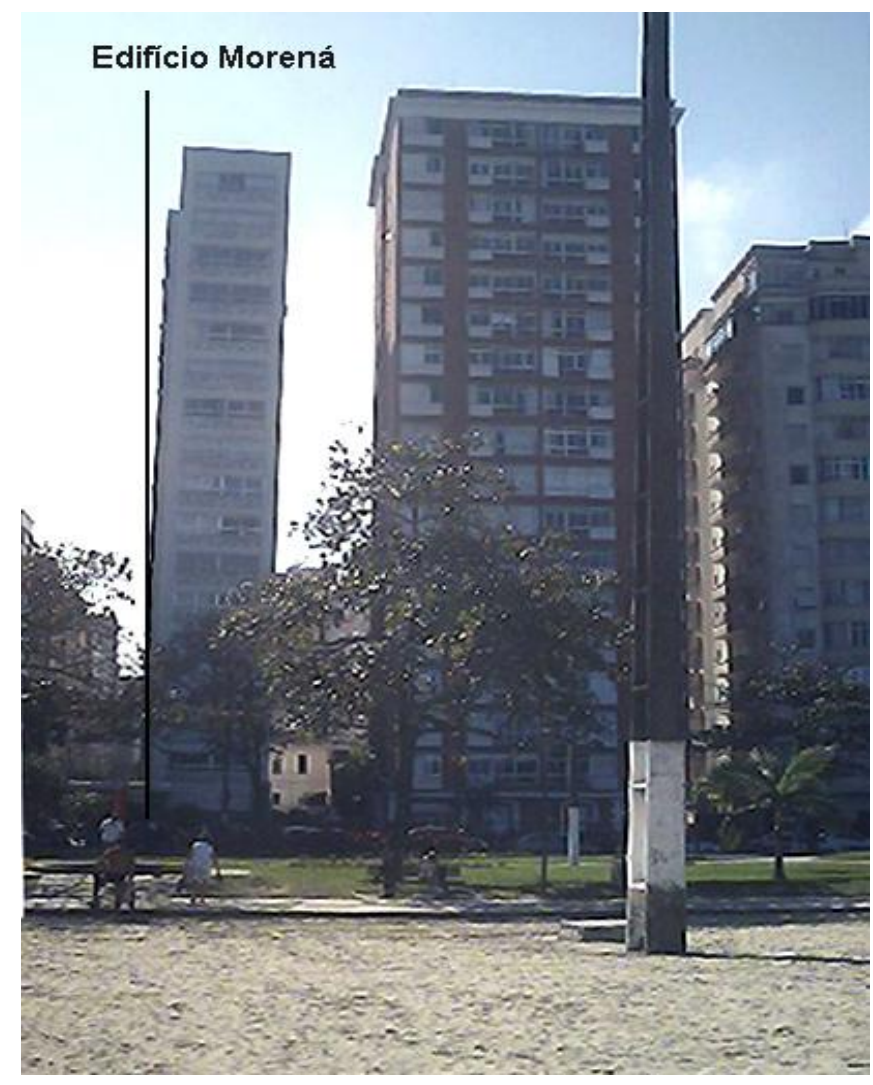

Foto 10 - Situação atual do edifício Morená 


\subsection{6 - Deformações controladas através da extração de solo mole}

O método consiste em provocar deformações controladas no edifício e seu conseqüente nivelamento através da extração da argila do lado menos recalcado e injeção de argamassa à medida que o trado inserido para a remoção da argila é retirado.

Falconi, et al. (2003), mostram esquematicamente como pode ser feita a extração de solo mole sob as sapatas (figura 13). Os autores ressaltam que esse procedimento exige um sistema de monitoramento contínuo dos recalques dos pilares, para acompanhar a eficiência do tratamento.

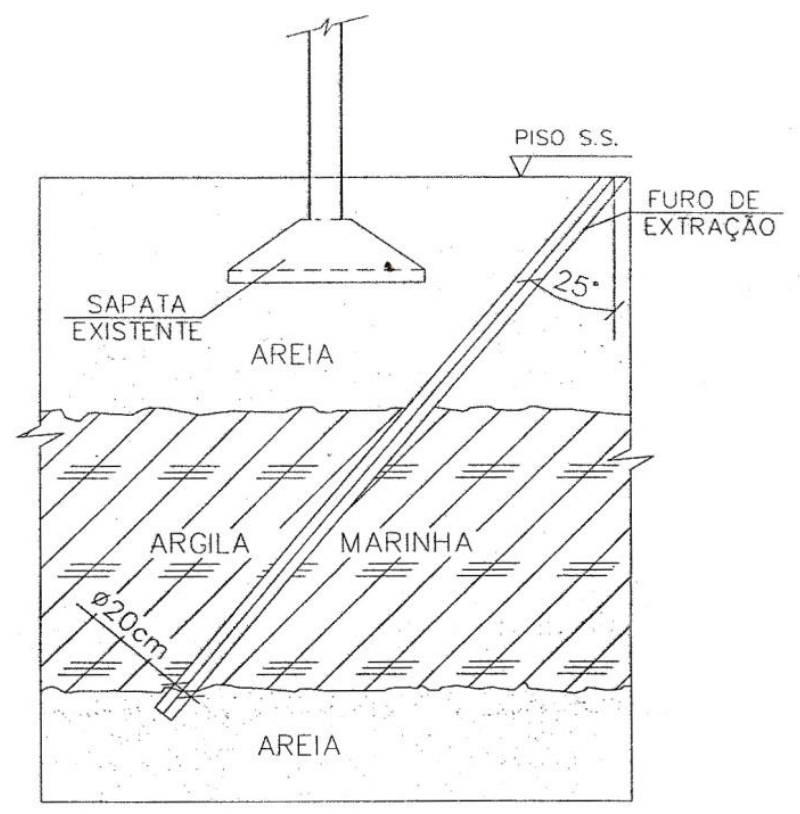

Figura 13 - Esquema representativo de como pode ser feita a extração de argila sob as sapatas (Fonte: Falconi et.al, 2003)

\subsubsection{O caso da torre de Pisa}

A Torre de Pisa que começou a ser construída em 1173 sendo finalizada somente em 1370, é um exemplo bem sucedido da extração de solo mole para estabilização de recalques; porém até chegar-se a essa solução, a edificação passou por diversas intervenções.

Segundo Jamiolkowiski (2000), já durante sua construção, foi notado que a torre começou a inclinar para o lado Sul. Na tentativa de compensar essa inclinação, foi 
feita uma mudança na espessura das pedras que compunham a torre e na posição do sino.

Em 1838, tentou-se retirar solo de cima das sapatas do lado mais recalcado; para isso foram feitos buracos de aproximadamente 3,0 $\mathrm{m}$ de largura, denominados de "catino" (figura 14). Como o fundo do catino foi executado abaixo do nível d' água, foi preciso drenar a água constantemente, o que contribuiu ainda mais para a evolução dos recalques. Somente em 1935 a drenagem foi suspensa pois, foi injetado cimento na base da torre e implementado um novo catino a "prova d' água".

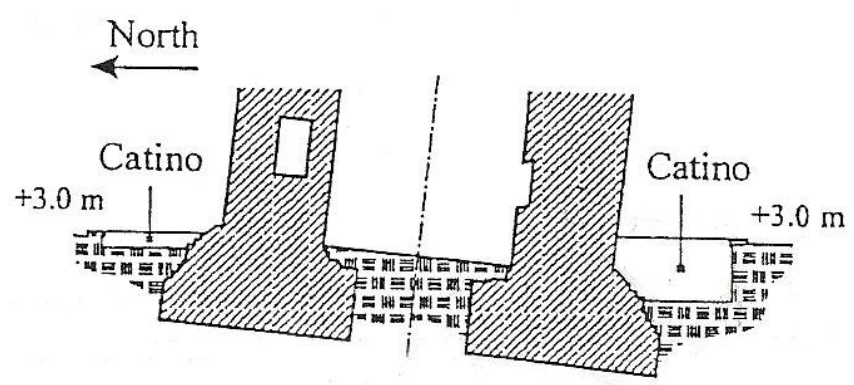

Figura 14 - Detalhe do catino (Fonte: Jamiolkowiski, 2000)

Em 1911, a Torre de Pisa começou a ser monitorada pelo método geodético. Em 1965, foram instalados quinze bench marks do lado mais inclinado para medição dos recalques.

Por volta de 1990, a inclinação da torre aumentava por volta de 5seg/ano; decidiu-se como solução temporária, instalar contrapesos na base da face norte da torre e amarra - lá com cabos de aço protendido. O contrapeso permaneceu na torre de maio de 1993 a janeiro de 1994.

Embora essa intervenção tenha sido a primeira a apresentar resultados positivos, diminuindo a inclinação da torre, devido ao aspecto visual decidiu-se retirar os contrapesos e substituí-los por 10 âncoras profundas, com carregamento de $1000 \mathrm{kN}$ cada, de forma que essa se tornasse uma solução definitiva para a torre (figura 15). 


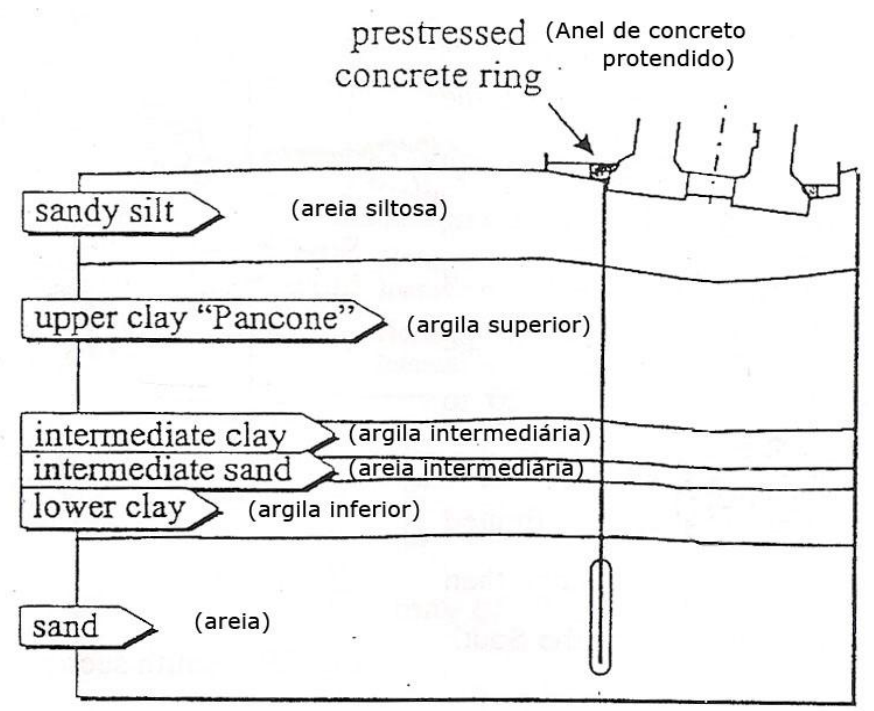

Figura 15 - Solução com âncoras (Fonte: Jamiolkowiski, 2000)

Ao contrário do que se previu, a solução não pode ser implantada pois, o "catino" e as injeções de concreto executadas anteriormente, se ligaram a fundação da torre, não trabalhando estaticamente isoladas como haviam imaginado. Na tentativa de remover o "catino" em pequenas partes, a torre começou a inclinar para o lado sul com grau de inclinação $=3 \mathrm{seg} / \mathrm{dia}$ causando muita preocupação. Esse fenômeno aconteceu em setembro de 1995 e foi remediado com a aplicação de $2700 \mathrm{kN}$ na base do lado norte da torre.

Entre 1997 e 2001 foi feito um trabalho especial de recuperação na torre. A solução encontrada por uma comissão de especialistas foi retirar gradativamente solo sob a fundação da torre, iniciando o processo de recuperação pelo lado menos recalcado.

Em 1999, foi iniciada a extração de solo do lado norte da torre. Devido aos resultados positivos, deu-se continuidade ao processo e, até maio de 2000 a Torre de Pisa teve uma redução na sua inclinação igual a 136 mm (Jamiolkowiski, 2000). Detalhe da solução empregada é destacado na figura 16.

\subsection{7 - Síntese dos métodos de estabilização de recalques apresentados}

A tabela III apresenta um resumo dos métodos de estabilização de recalques apresentados, destacando suas vantagens, desvantagens e aplicações 


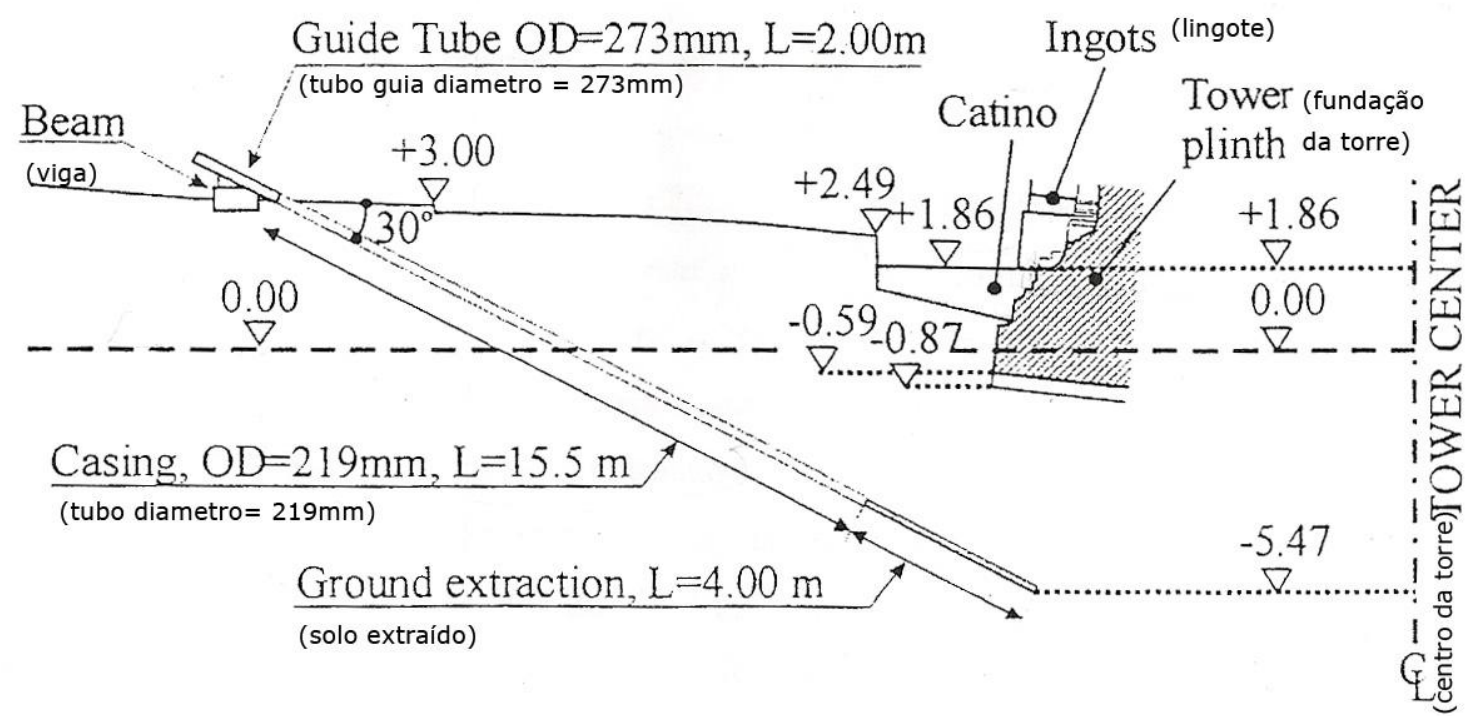

Figura 16 - Solução final - extração de solo ( Fonte: Jamiolkowiski, 2000)

Tabela III - Síntese dos métodos apresentados para estabilização de recalques

\begin{tabular}{|c|c|c|c|}
\hline MÉTODO & APLICAÇÃO & VANTAGENS & DESVANTAGENS \\
\hline Sangria & $\begin{array}{l}\text { Edifício Excelsior, } \\
\text { Morená (Santos) } \\
\text { Torre de Pisa } \\
\end{array}$ & - & $\begin{array}{c}\text { O método apresentou-se } \\
\text { ineficiente na estabilização } \\
\text { de recalques }\end{array}$ \\
\hline $\begin{array}{l}\text { Carregamento do } \\
\text { lado menos } \\
\text { recalcado ou } \\
\text { sobrecarga } \\
\text { temporária } \\
\end{array}$ & $\begin{array}{l}\text { Torre de Pisa, } \\
\text { Edifício Excelsior } \\
\text { (Santos) }\end{array}$ & Praticidade na execução & $\begin{array}{c}\text { Em Santos, a aplicação não } \\
\text { obteve resultado. Apresenta } \\
\text { grande poluição visual a } \\
\text { edificação }\end{array}$ \\
\hline $\begin{array}{l}\text { Injeções para } \\
\text { expandir o solo }\end{array}$ & $\begin{array}{l}\text { Palácio de Belas } \\
\text { Artes (México) }\end{array}$ & $\begin{array}{l}\text { Redução dos recalques } \\
\text { diferenciais e método } \\
\text { complementar para } \\
\text { garantia da estabilidade }\end{array}$ & $\begin{array}{l}\text { Em geral, o método não } \\
\text { interrompe totalmente os } \\
\text { recalques, mas tende a } \\
\text { torna- los uniforme. }\end{array}$ \\
\hline $\begin{array}{l}\text { Sistema cisalhante } \\
\text { de Ranzine }\end{array}$ & Nunca foi aplicado & - & $\begin{array}{c}\text { Dificuldade de criar um plano } \\
\text { vertical de resistência nula } \\
\text { ao cisalhamento }\end{array}$ \\
\hline $\begin{array}{l}\text { Reforço de fundação } \\
\text { com estacas } \\
\text { profundas }\end{array}$ & $\begin{array}{l}\text { Edifício Excelsior, } \\
\text { Edifício Morená, } \\
\text { Edifício Nuncio } \\
\text { Malzone. (Santos) }\end{array}$ & $\begin{array}{l}\text { Se empregado } \\
\text { corretamente, estabiliza os } \\
\text { recalques definitivamente. } \\
\text { Proporciona a possibilidade } \\
\text { de reaprumar as } \\
\text { edificações }\end{array}$ & $\begin{array}{l}\text { Somente a execução das } \\
\text { estacas não é suficiente para } \\
\text { reaprumar o edifício. Para o } \\
\text { reaprumo, é necessário um } \\
\text { sistema de macacos para } \\
\text { aplicação de cargas }\end{array}$ \\
\hline $\begin{array}{c}\text { Deformações } \\
\text { controladas através } \\
\text { da extração de solo } \\
\text { mole }\end{array}$ & $\begin{array}{l}\text { Cidade do México, } \\
\text { Torre de Pisa, }\end{array}$ & $\begin{array}{l}\text { Método eficiente na } \\
\text { estabilização de recalques }\end{array}$ & $\begin{array}{l}\text { Exige um sistema contínuo } \\
\text { de monitoramento dos } \\
\text { recalques dos pilares }\end{array}$ \\
\hline
\end{tabular}




\section{CAPÍTULO III - PROJETO ORLA E A PONTA DA PRAIA}

\section{1 - O PROJETO ORLA}

Em 2004, uma parceria entre Prefeitura Municipal de Santos, a Universidade Santa Cecília e Universidade de São Paulo, iniciou o desenvolvimento do projeto piloto denominado PROJETO ORLA, sob orientação do Engenheiro da prefeitura, Orlando Carlos Baptista Damim; da professora da Universidade Unisanta, Nilene Janini de Oliveira Seixas e da Professora Heloísa Helena Gonçalves, da Universidade de São Paulo.

A primeira etapa do projeto foi fazer um levantamento dos edifícios acima de três pavimentos ao longo de toda orla de Santos; a segunda, seria verificar a inclinação desses edifícios, e obter um número real de quais e quantas edificações existem com problemas significativos de recalques na cidade. A terceira consistiria na análise dos casos críticos, ou seja, com maior inclinação e a proposta de uma solução.

Segundo Gonçalves (2004), o projeto previa também um levantamento socioeconômico dos edifícios e a tentativa de criação de uma linha de créditos junto ao Governo Federal, para a recuperação dos mesmos.

A autora da presente pesquisa trabalhou no desenvolvimento e na execução do projeto durante seis meses, mas após o término da primeira fase, o projeto foi interrompido e não foi retomado até hoje.

\subsection{1 - Área de estudo}

No Projeto Orla, foram totalizadas 49 quadras ao longo da orla de Santos; todas foram demarcadas e numeradas como mostra a foto 11. 
Para desenvolvimento do presente trabalho, essa numeração será mantida, dandose ênfase a região da Ponta da Praia.

Levantamentos de campo ao longo das 49 quadras foram feitos para obter o nome dos edifícios, numeração e número de pavimento. Esses dados foram planilhados, e foi quantificado o número de edificações com mais de dois pavimentos em cada bairro. A tabela IV, extraída do Projeto Orla, mostra estes dados para os edifícios da Ponta praia, onde o levantamento foi feito em 2004.

\subsection{2 - Digitalização e elaboração de mapas}

Todas as quadras foram digitalizadas e os prédios locados com auxílio de fotos aéreas da cidade (foto 12). Quarenta e nove arquivos como a figura 17, foram gerados durante o desenvolvimento do Projeto Orla, para facilitar a execução das próximas etapas. Na época (2004) o mapeamento eletrônico da cidade não estava pronto, por isso foi preciso fazer os desenhos e criar os arquivos eletrônicos.

Hoje, no site da Prefeitura Municipal de Santos estão disponíveis mapas completos, indicando todos os bairros, ruas, lotes e os principais pontos históricos e turísticos da cidade. 
Tabela IV - Edifícios da orla do bairro da Ponta da Praia (Fonte: Projeto Orla, 2004)

\begin{tabular}{|c|c|c|c|c|c|}
\hline \multicolumn{5}{|c|}{ Ponta da Praia } & \multirow[b]{2}{*}{$>2$ pav. } \\
\hline Quadra & Endereço & $\mathbf{n}$ & Nome do Edifício & no pavimentos & \\
\hline \multirow{19}{*}{37} & Av.: Bartolomeu de Gusmão & 132 & Ed. Roma & 14 & \\
\hline & & 133 & Ed. Viena & 14 & \\
\hline & & 134 & Ed. Danúbio & 16 & \\
\hline & & 136 & Ed. Damasco & 13 & \\
\hline & Av.: Cel. Joaquim Montenegro & 10 & Comercio & 1 & \\
\hline & & 12 & Sobrado & 2 & \\
\hline & & 14 & Ed. Eli & 11 & \\
\hline & & 20 & Ed. Monte negro & 9 & \\
\hline & & 22 & Ed. Sanyra & 10 & \\
\hline & & 26 & Sobrado & 2 & \\
\hline & & $34 / 36$ & Prédio comercial & 3 & \\
\hline & Av.: Epitácio Pessoa & 578 & Ed. Civitamar & 16 & \\
\hline & & 580 & Ed. Milão & 13 & \\
\hline & & 582 & Ed. Turim & 13 & \\
\hline & Rua Bassin Nagib Trabulsi & 50 & Ed. Genebra & 13 & \\
\hline & & 90 & Ed. Antilhas & 13 & \\
\hline & & 106 & Ed. Anduras & 13 & \\
\hline & & 130 & Ed.Cairo & 13 & \\
\hline & & 158 & Ed. Bagda & 13 & 16 \\
\hline \multirow{16}{*}{38} & Av.: Bartolomeu de Gusmão & 138 & Ed. Madrid & 16 & \\
\hline & & 144 & Ed. Sem nome & 12 & \\
\hline & & 146 & Ed.Barra Linda & 10 & \\
\hline & Rua Bassin Nagib Trabulsi & 43 & Ed.Luxemburgo & 13 & \\
\hline & & 87 & Ed.Marselha & 13 & \\
\hline & & 107 & Ed. Atenas & 13 & \\
\hline & & 125 & Ed. Florença & 13 & \\
\hline & & 145 & Ed. Genova & 13 & \\
\hline & Av.: Epitácio Pessoa & 646 & Ed. Lisboa & 14 & \\
\hline & Rua Roberto Sandall & 28 & Ed. Tangará & 11 & \\
\hline & & 52 & Ed. Hawai & 11 & \\
\hline & & 76 & Ed. Jandaia & 11 & \\
\hline & & 106 & Ed. Graúna & 11 & \\
\hline & & 128 & Ed. Caledônia & 9 & \\
\hline & & 150 & Ed. São Judas Tadeu & 12 & \\
\hline & & 174 & Ed. Ancora & 12 & 16 \\
\hline \multirow{17}{*}{39} & Av.: Bartolomeu de Gusmão & \multirow{2}{*}{151} & Ed. Ponta Mar & 13 & \\
\hline & & & Ed. Barramar & 13 & \\
\hline & Rua Roberto Sandall & 31 & Ed. Itaguaré & 13 & \\
\hline & & 67 & Ed. Torre Mar & 6 & \\
\hline & & 83 & Ed. Praia Morena & 10 & \\
\hline & & 111 & Ed. Guaraciaba & 3 & \\
\hline & & 135 & Ed. Itapoa & 10 & \\
\hline & & 153 & Ed.Guardia & 10 & \\
\hline & & 181 & Ed. Timão & 11 & \\
\hline & Av.: Epitácio Pessoa & 656 & Ed. Guadalajara & 9 & \\
\hline & Rua Inglaterra & 3 & Ed. Inglaterra & 14 & \\
\hline & & 5 & Ed. Daniel Lopes & 9 & \\
\hline & & $11 / 13$ & Sobrado (Comercio) & 2 & \\
\hline & & 17 & Ed. Caiobá & 9 & \\
\hline & & 21 & Ed. Golden Liverpool & 16 & \\
\hline & & 29 & Ed. Inglaterra & 3 & \\
\hline & & 31 & Ed. Tamisa & 3 & 16 \\
\hline
\end{tabular}




\begin{tabular}{|c|c|c|c|c|c|}
\hline Quadra & Endereço & $\mathbf{n}$ & Nome do Edifício & $\mathrm{n}$ \% pavimentos & $>2$ pav. \\
\hline \multirow{32}{*}{40} & Av.: Bartolomeu de Gusmão & 154 & Sobrado & 2 & \\
\hline & & 155 & Sobrado (comercio) & 2 & \\
\hline & & 156 & Comércio & 2 & \\
\hline & & 157 & Ed. Aldebaram & 12 & \\
\hline & & 159 & Ed. Albamar & 13 & \\
\hline & Rua Inglaterra & 4 & Ed. Azul do Mar & 10 & \\
\hline & & 8 & Casa & 1 & \\
\hline & & 12 & Ed. Amapá & 5 & \\
\hline & & $14 / 16$ & Casa & 1 & \\
\hline & & 18 & Ed. Camburiú & 5 & \\
\hline & & 22 & Ed. Robby & 3 & \\
\hline & & 26 & Ed. Tenessee & 13 & \\
\hline & & 28 & Ed. Mont Royal & 12 & \\
\hline & & 34 & Ed. Vila Inglesa & 4 & \\
\hline & & 36 & Ed. Magali & 3 & \\
\hline & & 40 & Casa & 1 & \\
\hline & Av.: Epitácio Pessoa & 658 & Ed. Remanso & 11 & \\
\hline & & $660 / 662$ & Sobrado (comercio) & 2 & \\
\hline & & \multirow{3}{*}{664} & Cond. Jardim América & - & \\
\hline & & & Ed. Jamaica & 7 & \\
\hline & & & Ed. Honduras & 7 & \\
\hline & & 666 & Sobrado (comercio) & 2 & \\
\hline & & 674 & Ed. Aquarios & 5 & \\
\hline & Rua Izidoro R. de Campos & 23 & Em obras & & \\
\hline & & 29 & Sobrado & 2 & \\
\hline & & 31 & Sobrado (comercio) & 2 & \\
\hline & & 35 & Ed. Vermont & 12 & \\
\hline & & 41 & Ed. Emilio Cassasco Jr & 9 & \\
\hline & & 43 & Ed. Diamont & 5 & \\
\hline & & 47 & Sobrado & 2 & \\
\hline & & 59 & Sobrado & 2 & \\
\hline & & 63 & Ed. Jaguari & 9 & 18 \\
\hline \multirow{25}{*}{41} & Av.: Bartolomeu de Gusmão & 161 & Ed. Saint Vallier & 10 & \\
\hline & Rua Izidoro de Campos & 20 & Casa & 1 & \\
\hline & & $22 / 24$ & Sobrado & 2 & \\
\hline & & $26 / 28$ & Sobrado & 2 & \\
\hline & & 30 & Sobrado (comércio) & 2 & \\
\hline & & $32 / 34$ & Sobrado & 2 & \\
\hline & & 36 & Sobrado & 2 & \\
\hline & & 38 & Comércio & 1 & \\
\hline & & $40 / 42 / 44 / 46$ & Sobreposta & 2 & \\
\hline & & $48 / 50$ & Sobrado & 2 & \\
\hline & & 54 & Sobrado & 2 & \\
\hline & & $56 / 58$ & Sobrado & 2 & \\
\hline & & 60 & Sobrado & 2 & \\
\hline & Av.: Epitácio Pessoa & 680 & Ed. Manuel Rodrigues & 6 & \\
\hline & & 686 & Ed. Maison Voltaire & 11 & \\
\hline & & 688 & Ed. Guapirama & 3 & \\
\hline & & 692 & Ed Rainha do Mar & 4 & \\
\hline & Rua Imperatriz Leopoldina & 7 & Ed. Estuario & 13 & \\
\hline & & 11 & Ed. Arco Verde & 4 & \\
\hline & & 15 & Casa da Esperança & 1 & \\
\hline & & 25 & Casa & 1 & \\
\hline & & 27 & Ed. Mansão dos Nobres & 11 & \\
\hline & & 31 & Ed. Marques de Olinda & 4 & \\
\hline & & 33 & Casa & 1 & \\
\hline & & 37 & Sobrado & 2 & 9 \\
\hline
\end{tabular}




\begin{tabular}{|c|c|c|c|c|c|}
\hline Quadra & Endereço & $\mathbf{n}$ & Nome do Edifício & no pavimentos & $>2$ pav. \\
\hline \multirow{28}{*}{42} & Av.: Bartolomeu de Gusmão & 174 & Ed. Beira Mar & 16 & \\
\hline & Rua Imperatriz Leopoldina & 4 & Ed. Prelúdio & 16 & \\
\hline & & 8 & Sobrado & 2 & \\
\hline & & 10 & Ed. Lord Luxor & 6 & \\
\hline & & 14 & Ed. Imperatriz Leopoldina & 9 & \\
\hline & & 16 & Sobrado & 2 & \\
\hline & & 20 & Casa & 1 & \\
\hline & & 28 & Sobrado & 2 & \\
\hline & & 30 & Colégio & 2 & \\
\hline & & 34 & Sobrado (comércio) & 2 & \\
\hline & & $36 / 38$ & Sobrado (comércio) & 2 & \\
\hline & & $40 / 42$ & Sobrado & 2 & \\
\hline & & $46 / 48$ & Sobrado & 2 & \\
\hline & Av.: Epitácio Pessoa & $696 / 698$ & Sobrado (comércio) & 2 & \\
\hline & & $700 / 702$ & Sobrado (comércio) & 2 & \\
\hline & Rua Carlos de Campo & $03 / 05$ & Sobrado (comércio) & 2 & \\
\hline & & $07 / 09$ & Sobrado (comércio) & 2 & \\
\hline & & $15 / 17$ & Sobrado & 2 & \\
\hline & & $19 / 21$ & Sobrado & 2 & \\
\hline & & $23 / 25$ & Sobrado & 2 & \\
\hline & & $27 / 29$ & Sobrado & 2 & \\
\hline & & $31 / 33$ & Sobrado & 2 & \\
\hline & & $35 / 37$ & Sobrado & 2 & \\
\hline & & $39 / 41$ & Sobrado & 2 & \\
\hline & & $43 / 45$ & Sobrado & 2 & \\
\hline & & $47 / 49$ & Sobrado (comércio) & 2 & \\
\hline & & $51 / 53$ & Sobrado (comércio) & 2 & \\
\hline & & $55 / 57$ & Sobrado & 2 & 4 \\
\hline \multirow{29}{*}{43} & Av.: Bartolomeu de Gusmão & 176 & Ed. $S / n$ & 3 & \\
\hline & & 178 & Ed. Paysage & 13 & \\
\hline & & 180 & Ed. Enseada & 14 & \\
\hline & Rua Afonso Celso de P. Lima & 21 & Ed Estrela Do mar & 4 & \\
\hline & & $23 / 25$ & Sobrado (Comércio) & 2 & \\
\hline & & 27 & Ed. Afonso Celso & 4 & \\
\hline & & 29 & Casa & 1 & \\
\hline & & 31 & Ed. Nosso Mar & 3 & \\
\hline & & 37 & Ed. Dirce & 4 & \\
\hline & & 39 & Sobrado & 2 & \\
\hline & & 43 & Ed. São Luiz Gonzaga & 10 & \\
\hline & & 47 & Ed. Nacolomi & 4 & \\
\hline & & 49 & Sobrado & 2 & \\
\hline & & 51 & Sobrado & 2 & \\
\hline & & $55 / 57$ & Sobrado & 2 & \\
\hline & Rua Carlos de Campos & 6 & Ed. Península & 15 & \\
\hline & & 18 & Ed. Taruma & 9 & \\
\hline & & 22 & Ed. Emaús & 6 & \\
\hline & & 30 & Ed. Jóia do Mar & 9 & \\
\hline & & 32 & Casa & 1 & \\
\hline & & 34 & Casa & 1 & \\
\hline & & 36 & Ed. S/n & 3 & \\
\hline & & $40 / 42$ & Sobrado & 2 & \\
\hline & & $44 / 46$ & Ed. Augusta & 3 & \\
\hline & & 50 & Ed. São Luiz & 3 & \\
\hline & & $64 / 66$ & Sobrado & 2 & \\
\hline & & $70 / 72$ & Sobrado & 2 & \\
\hline & & $76 / 78$ & Ed. S/n & 3 & \\
\hline & & 80 & Sobrado & 2 & 17 \\
\hline
\end{tabular}




\begin{tabular}{|c|c|c|c|c|c|}
\hline Quadra & \begin{tabular}{|c|} 
Endereço \\
\end{tabular} & $\mathbf{n}$ & Nome do Edifício & $\mathrm{n}$ - pavimentos & $>2$ pav. \\
\hline \multirow{8}{*}{44} & Av.: Almirante Saldanha da Gama & 192 & Museu de Pesca & 2 & \\
\hline & & $\mathrm{s} / \mathrm{n}$ & Comércio & 1 & \\
\hline & Rua Afonso Celso Lima & $2 / 4$ & Ed. Canto do Mar & 4 & \\
\hline & & 10 & Ed. Ita & 3 & \\
\hline & & $12 / 14$ & Sobrado & 2 & \\
\hline & & 16 & Estacionamento & 1 & \\
\hline & Av.: Rei Alberto I & & Clube Internacional & \multirow{2}{*}{1} & \\
\hline & Rua Francisco Hayden & 5 & Clube Internacional & & 2 \\
\hline \multirow{18}{*}{45} & Av: Almirante Saldanha da Gama & 23 & Clube de Regatas Santista & 1 & \\
\hline & & 33 & Clube de Regatas Vasco da Gama & 1 & \\
\hline & & 44 & Clube de Regatas Saldanha da Gama & 1 & \\
\hline & & 64 & Praticagem & 2 & \\
\hline & & 67 & Ed. Pontal da Barra & 8 & \\
\hline & & 69 & Sobrado (comércio) & 2 & \\
\hline & & 71 & Ed. Cabo Frio & 3 & \\
\hline & & 72 & Ed. Golden Ocean & 15 & \\
\hline & Rua Francisco Hayden & & Clube Regatas Santista & - & \\
\hline & Av.: Rei Alberto I & & Clube de Regatas Vasco da Gama & - & \\
\hline & & & Clube de Regatas Saldanha da Gama & - & \\
\hline & & \multirow{2}{*}{198} & Sobrepostas & 2 & \\
\hline & & & Sobrepostas & 2 & \\
\hline & & 200 & Sobrado (Comércio) & 2 & \\
\hline & & 208 & Ed. N. S. de Lourdes & 4 & \\
\hline & Rua Cap. João Salermo & $19 / 21$ & Sobrado & 2 & \\
\hline & & $23 / 29$ & Ed. S/N & 3 & \\
\hline & & 31 & Ed. Vitalina & 3 & 6 \\
\hline & & & & & \\
\hline \multirow{23}{*}{46} & Av.: Almirante Saldanha da Gama & 81 & Terreno Vazio & - & \\
\hline & & 83 & Ed. Navegantes & 3 & \\
\hline & & 85 & Clube de Pesca & 1 & \\
\hline & & 89 & Unimonte & 3 & \\
\hline & & \multirow{6}{*}{96} & Cond. Jardins da Grécia & & \\
\hline & & & Ed. Atenas & 28 & \\
\hline & & & Ed. Apolo & 28 & \\
\hline & & & Ed. Hericles & 28 & \\
\hline & & & Ed. Afrodite (em construção) & - & \\
\hline & & & Ed. Hermes (em construção) & - & \\
\hline & Rua Cap. João Salermo & $6 / 8$ & Ed. Conceição Martins & 4 & \\
\hline & & $16 / 18$ & Sobrado & 2 & \\
\hline & & $20 / 22$ & Sobrado & 2 & \\
\hline & & $24 / 26$ & Sobrado & 2 & \\
\hline & & $28 / 30$ & Sobrado & 2 & \\
\hline & & 32 & Ed. Caviana & 4 & \\
\hline & & 34 & Ed. Rei Alberto & 3 & \\
\hline & Av.: Rei Alberto I & 222 & Ed. Cidamar & 3 & \\
\hline & & \multirow{3}{*}{224} & Ed. S/N & - & \\
\hline & & & Bloco A & 3 & \\
\hline & & & Bloco B & 3 & \\
\hline & & 248 & Ed. Puerta del Sol & 14 & \\
\hline & Rua Daniel Carvalho & & & & 12 \\
\hline
\end{tabular}




\begin{tabular}{|c|c|c|c|c|c|}
\hline Quadra & \begin{tabular}{|l|} 
Endereço \\
\end{tabular} & $\mathbf{n}$ & Nome do Edifício & no pavimentos & $>2$ pav. \\
\hline \multirow{5}{*}{47} & Av.: Almirante Saldanha da Gama & 111 & Banco & 1 & \\
\hline & & 114 & lgreja & 1 & \\
\hline & Rua Daniel Carvalho & 35 & Ed. Fragata & 5 & \\
\hline & Av.: Rei Alberto I & 278 & Sobrado (comercio) & 2 & \\
\hline & Rua Antonio Guenaga & 86 & Ed. Empresarial Albatroz & 5 & 2 \\
\hline \multirow{11}{*}{48} & & & & & \\
\hline & Av.: Saldanha da Gama & 121 & Ed. Mont Blanc & 14 & \\
\hline & & 125 & Terreno Vazio & - & \\
\hline & & $126 / 127$ & Edificio (Comercio) & 3 & \\
\hline & & 137 & Ed. Aragarças & 3 & \\
\hline & & 141 & Ed. Solmar & 8 & \\
\hline & & 145 & Senai & 2 & \\
\hline & Rua Antonio Guenaga & 43 & Ed. Mont Clair & & \\
\hline & Av.: Rei Alberto I & 316 & Casa & 1 & \\
\hline & & 326 & Ed. Ana Carolina & 8 & \\
\hline & Rua Áureo Conde & & & & 6 \\
\hline \multirow{20}{*}{49} & Av: Almirante Saldanha da Gama & 159 & Sobrado (comércio) & 2 & \\
\hline & & 161 & Casa & $\frac{c}{1}$ & \\
\hline & & 163 & Clube Estrela & 3 & \\
\hline & & 174 & Terreno Vazio & - & \\
\hline & & 177 & Campo de Futebol & - & \\
\hline & & 182 & Comércio & 2 & \\
\hline & & $183 / 184$ & Sobrado (comércio) & 2 & \\
\hline & & $186 / 188$ & Sobrado (comércio) & 2 & \\
\hline & & 194 & Ed. Irmão Castro Conde & 4 & \\
\hline & & 200 & Posto de Gasolina & 1 & \\
\hline & Rua Áure Conde & & & & \\
\hline & Av.: Rei Alberto I & 362 & Casa & 1 & \\
\hline & & 364 & Casa (comércio) & 1 & \\
\hline & & 388 & Casa (comércio) & 1 & \\
\hline & & 402 & Estacionamento & 1 & \\
\hline & & $s / n$ & Terreno Vazio & 1 & \\
\hline & & 422 & Garagem do Ed. Irmãos Castro Conde & 1 & \\
\hline & & 424 a 434 & Ed. Comercial & 3 & \\
\hline & Pça Gago Coutinho & $03 / 06$ & Ed. Comercial & 3 & \\
\hline & & 8 & Sobrado (comércio) & 2 & 4 \\
\hline & TOTAL & & \multicolumn{2}{|l|}{$>2$ pavimentos no bairro } & 128 \\
\hline
\end{tabular}




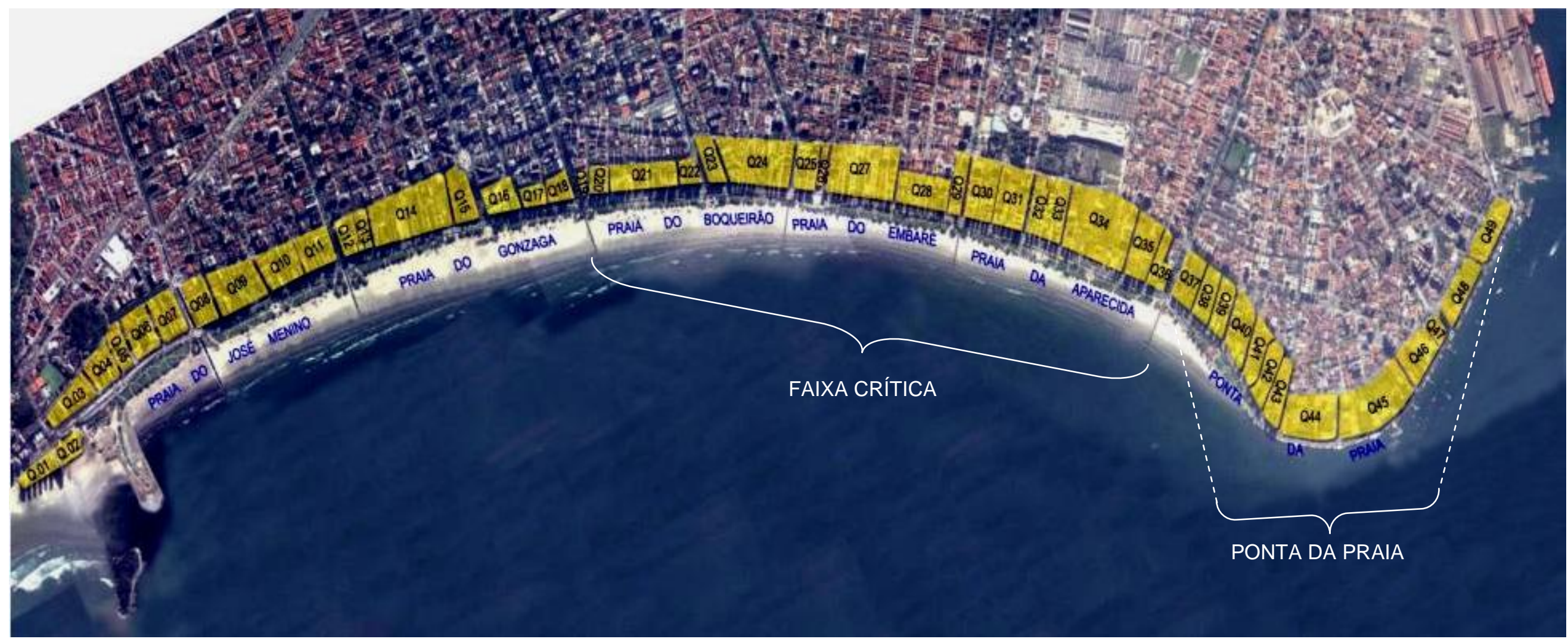

Foto 11 - Delimitação das 49 quadras ao longo de toda orla Santista - (Fonte: Adaptado de Google Earth, jan, 2009) 


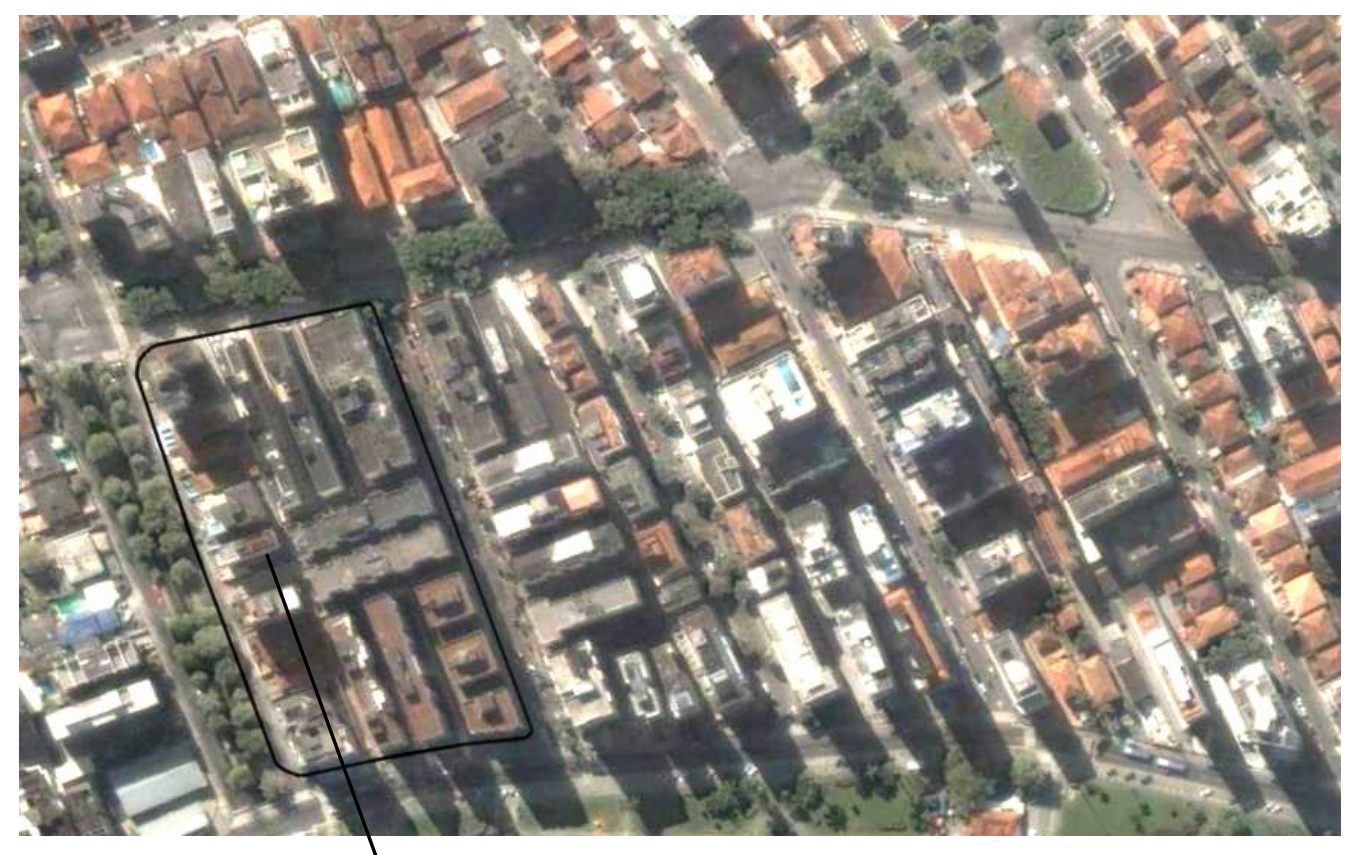

Foto 12 - Processo de digitalização das quadras - exemplo quadra 37 (Fonte: Projeto Orla, 2004)

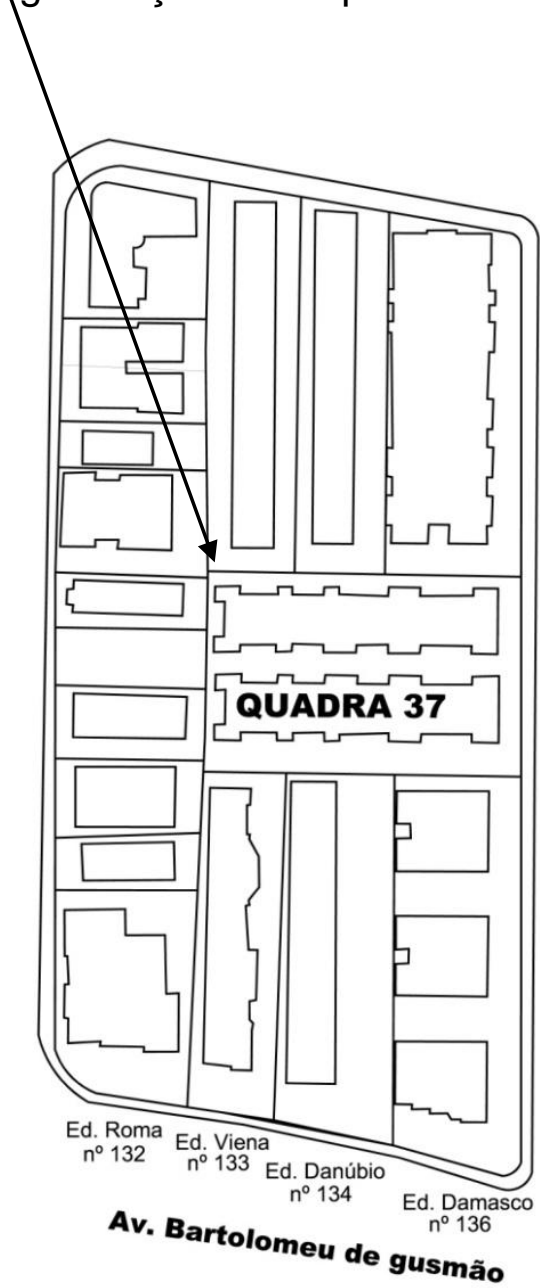

Figura 17 - Arquivo final gerado (Fonte: Projeto Orla, 2004). 


\section{2 - PONTA DA PRAIA}

\subsection{1 - Características e localização}

Compreendido entre o canal 6 e a balsa de travessia para o Guarujá, quadras 37 a 49 (figura 18), o bairro da Ponta da Praia será abordado neste capítulo

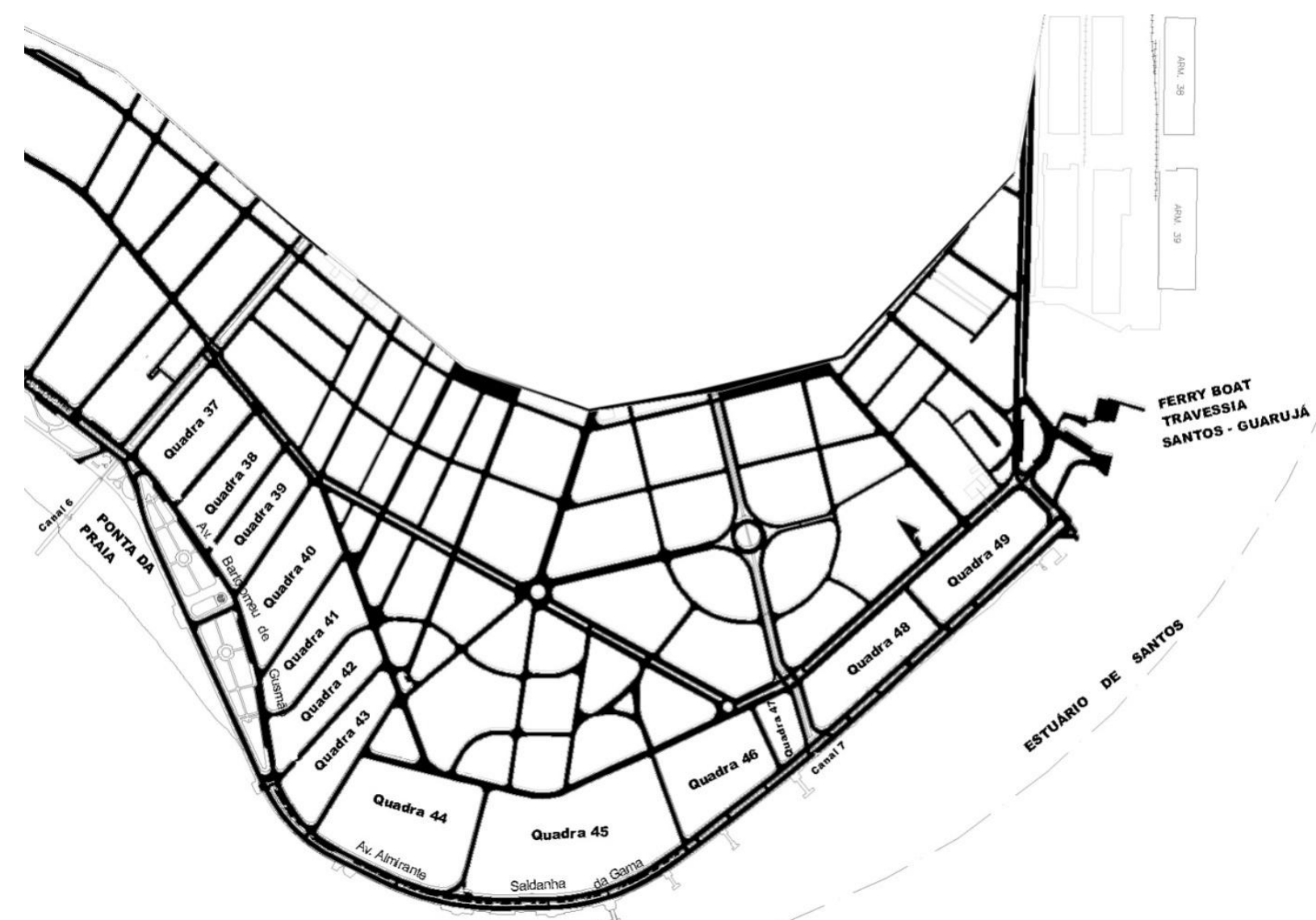

Figura 18 - Bairro da Ponta da Praia quadras de 37 a 49 (Fonte: adaptado de http://www.digital.santos.sp.gov.br, set, 2007 )

Entre as décadas de 70 e 80, a população da Ponta da Praia dobrou; dos 19.367 habitantes registrados pelo Censo de 1970, passou-se para 41.811 em 1980. De repente, muitos começaram a optar por esse bairro que, se distingue dos demais entre outras coisas, por registrar temperaturas dois ou três graus abaixo da média de Santos. Entre todos os bairros da orla da praia, é o de ocupação mais recente. Suas ruas só começaram a ser drenadas e pavimentadas em 1967, e só a partir de então se verificou crescimento populacional marcante. As fotos 13,14 e 15 ilustram o bairro da Ponta da Praia nos anos 20,40 e 2004, respectivamente. 
"Parece um pouco estranho, mas o fato é que o vento que sopra do mar, de Sudeste para Leste, faz com que lá seja o lugar mais fresco de Santos. Hoje se trata também de um dos bairros mais valorizados da cidade concentrando dezenas de mansões." (Mondin, L - Disponível em: http:// www.novomilenio.inf.br)

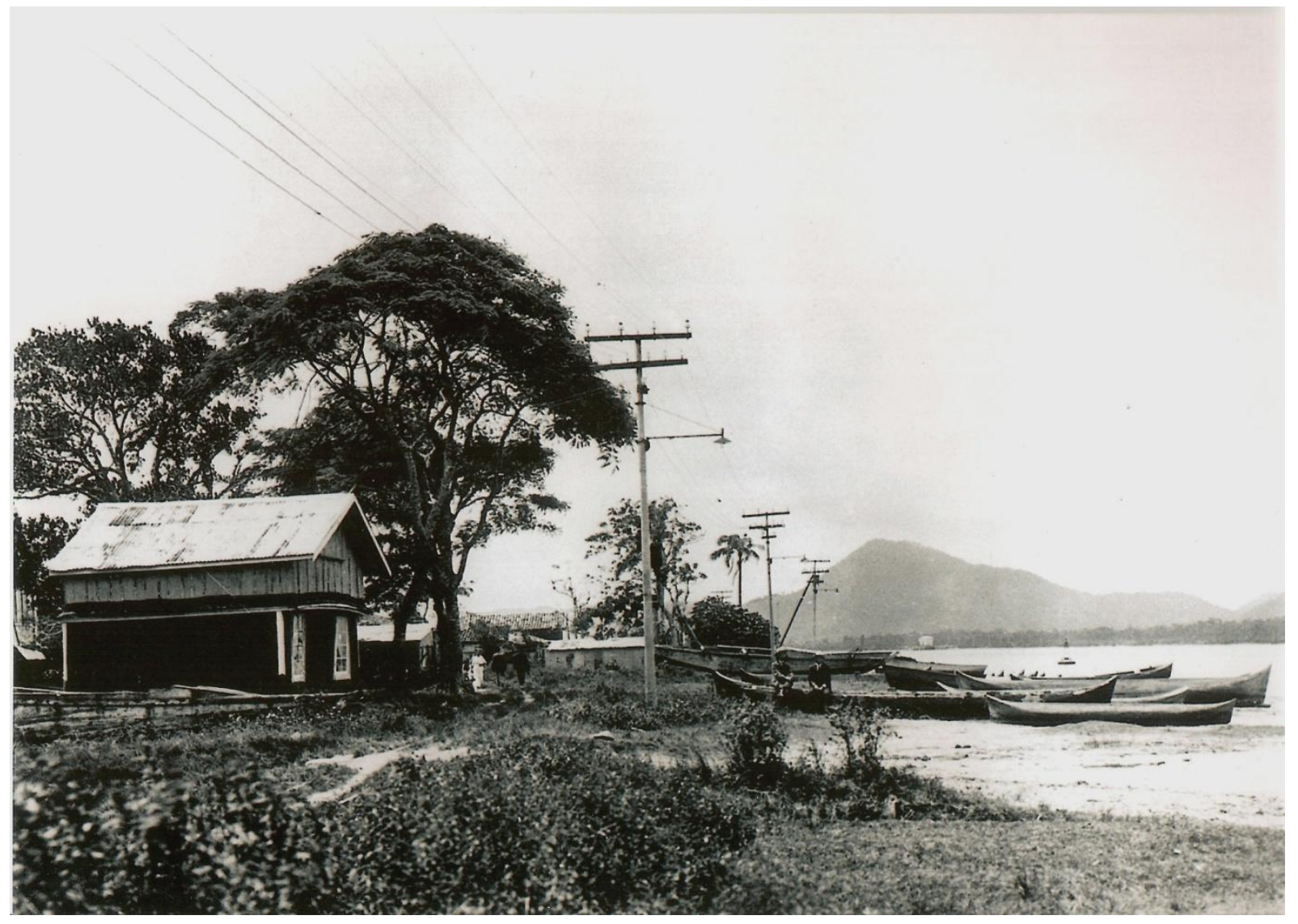

Foto 13 - Bairro da Ponta da Praia por volta dos anos 20 ou 30, onde ainda não existia calçadão e as casas eram na areia. Pode-se notar também a presença de pequenos "jundus" à esquerda da foto. (Fonte: Ary Célio - contato pessoal) 


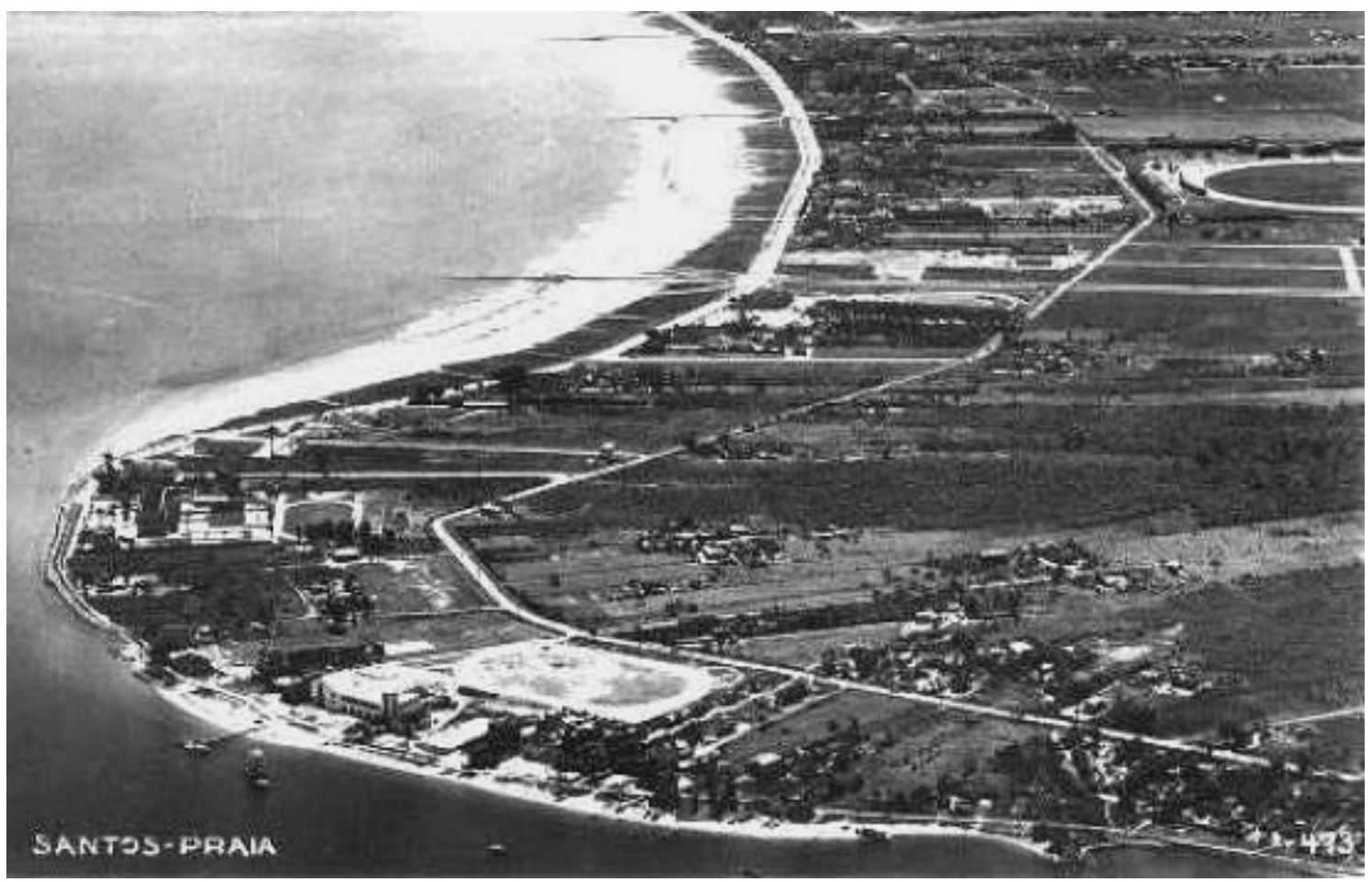

Foto 14 - Ponta da Praia em 1940. (Fonte: http: // www.novomilenio.inf.com.br, jul 2008)

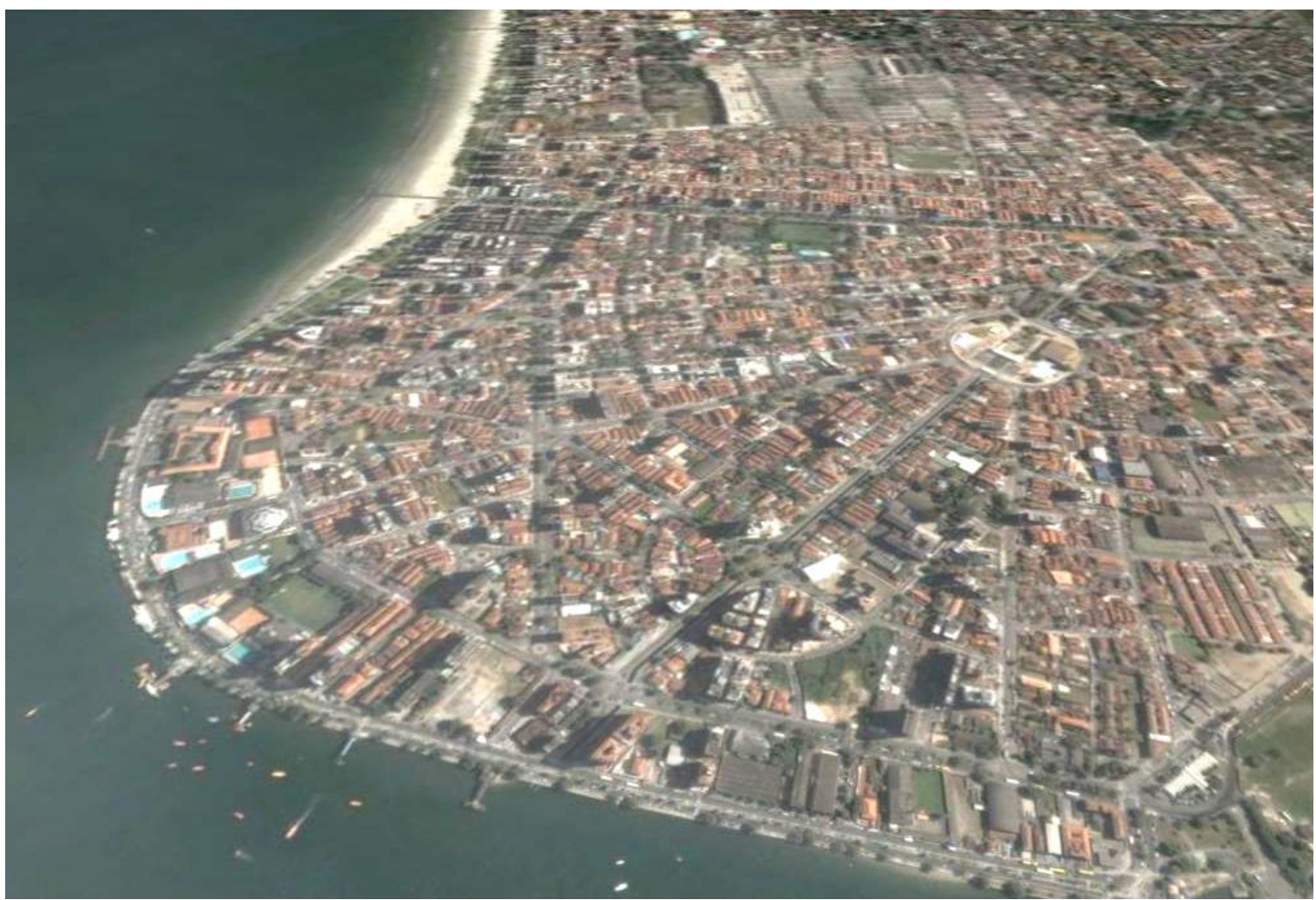

Foto15 - Ponta da Praia atualmente (2004). (Fonte: Google Earth, março, 2009) 


\subsection{2 - Levantamento de dados na Prefeitura Municipal de Santos}

Como dito anteriormente, o objetivo da pesquisa é comparar as características do solo do bairro da Ponta da Praia com os dados existentes da "Faixa Crítica", região onde estão concentrados o maior número de prédios com problemas de recalques, facilmente perceptíveis a olho nu.

Para dar início as comparações foi preciso primeiramente saber se os edifícios foram construídos na mesma época e se possuem fundação direta, apoiados na camada superficial de areia. Essa dúvida surgiu, pelo fato de a Ponta da Praia ter sido o último bairro da Orla praiana a ser ocupado.

A partir dessa etapa, os dados foram levantados pela autora do presente trabalho, e não mais extraídos do Projeto Orla, desenvolvido em 2004. Para levantar o tipo de fundação dos edifícios havia duas maneiras: uma seria procurar as construtoras dos edifícios e ter acesso aos projetos; a outra, seria fazer uma pesquisa nos arquivos da Prefeitura. Como na maioria dos casos a construtora do edifício não existe mais, a busca foi feita nos arquivos da Prefeitura.

A Prefeitura Municipal de Santos concedeu uma autorização para pesquisar em seus arquivos internos, os processos existentes relativos aos edifícios da orla. Como cada edifício possui mais de um número de processo, e esses ficam arquivados em lugares diferentes da cidade, não foi possível ter acesso a todos, mesmo porque alguns são muito antigos e não foram cadastrados no banco de dados da Prefeitura.

Todo esse procedimento foi um pouco longo pois, mesmo depois de localizar os processos, era necessário fazer o pedido ao departamento, e até o processo chegar, demorava de uma a duas semanas. Também não era possível pedir todos de uma só vez, pois a Prefeitura possui um limite médio de dez processos por solicitação. A tabela $V$ é um resumo contendo o número do processo, ano e localização no arquivo para os edifícios da Ponta da Praia. 
Tabela V - Tabela resumo especificando os processos existentes e a sua localização

\begin{tabular}{|c|c|c|c|c|}
\hline Endereço & Nome do Edificio & Processo & Ano & localização \\
\hline \multirow{3}{*}{ Bartolomeu . Gusmão n 132} & \multirow{3}{*}{ Roma } & 20617 & 1973 & SEAOP \\
\hline & & 25983 & 1973 & FAMS - AG \\
\hline & & 45165 & 2002 & PROJUR \\
\hline \multirow{4}{*}{ Bartolomeu . Gusmão n 133} & \multirow{4}{*}{ Viena } & 15691 & 1976 & N/ cadastrado \\
\hline & & 0.5391 & 1980 & N/ cadastrado \\
\hline & & 57272 & 1986 & $\mathrm{~N} /$ cadastrado \\
\hline & & 96677 & 2005 & $\mathrm{~N} /$ cadastrado \\
\hline \multirow{5}{*}{ Bartolomeu . Gusmão n 134} & \multirow{5}{*}{ Danubio } & 5444 & 1943 & $\mathrm{~N} /$ cadastrado \\
\hline & & 10370 & 1944 & N/ cadastrado \\
\hline & & 26199 & 1962 & FAMS - AI \\
\hline & & 25740 & 1969 & $\mathrm{~N} /$ cadastrado \\
\hline & & 23790 & 1987 & $\mathrm{~N} /$ cadastrado \\
\hline \multirow{4}{*}{ Bartolomeu . Gusmão n 136} & \multirow{4}{*}{ Damasco } & 22491 & 1976 & FAMS - AI \\
\hline & & 7515 & 1962 & $\mathrm{~N} /$ cadastrado \\
\hline & & 0.2008 & 1977 & N/ cadastrado \\
\hline & & 30099 & 1979 & $\mathrm{~N} /$ cadastrado \\
\hline \multirow{2}{*}{ Bartolomeu . Gusmão n 138} & \multirow{2}{*}{ Madrid } & 17815 & 1961 & FAMS-Al \\
\hline & & 18725 & 1972 & N/ cadastrado \\
\hline \multirow{2}{*}{ Bartolomeu . Gusmão n 144} & \multirow{2}{*}{ Presidente Prudente } & 21702 & 1941 & $\mathrm{~N} /$ cadastrado \\
\hline & & 20131 & 1964 & FAMS-Al \\
\hline \multirow{3}{*}{ Bartolomeu . Gusmão n 146} & \multirow{3}{*}{ Barra Linda } & 10420 & 1956 & FAMS - AI \\
\hline & & 21105 & 1959 & FAMS - Al \\
\hline & & 80661 & 2001 & DEOP \\
\hline Bartolomeu . Gusmão n 151 & Ponta mar - Barramar & 23267 & 1976 & $\mathrm{~N} /$ encontrado \\
\hline Bartolomeu Gusmãon 153 & Azuldo Mar & \begin{tabular}{|c|}
7818 \\
\end{tabular} & 1951 & N/ cadastrado \\
\hline Bartolomeu. Gusmao n i5s & Azuldo Iviar & anexado ao 66280 & 2005 & $\mathrm{~N} /$ cadastrado \\
\hline & & 29764 & 1964 & $\mathrm{~N} /$ cadastrado \\
\hline & & 26427 & 1969 & N/ cadastrado \\
\hline Bartolomeu. Gusmāo n 157/158 & Aldebaram & $82816-11$ & 2005 & $\mathrm{~N} /$ cadastrado \\
\hline & & 26194 & 1970 & SEPROT \\
\hline & & 4455 & 1970 & FAMS - AG \\
\hline Bartolomeu . Gusmão n 159 & Albamar & 5839 & 1970 & $\mathrm{~N} /$ cadastrado \\
\hline & & 28177 & 1975 & FAMS - AI \\
\hline Bartolomeu . Gusmão n 161 & Saint Valier & 15343 & 1939 & $\mathrm{~N} /$ cadastrado \\
\hline Bartolomeu . Gusmão n 174 & Beira Mar & 45194 & 1990 & SEPROT \\
\hline Bartolomeu . Gusmão n 176 & Comercial & 6281 & 1942 & APM - FAMS \\
\hline & & 9139 & 1946 & N/ cadastrado \\
\hline Bartolomeu . Gusmão n 178 & Paysage & 3581 & 1974 & $\mathrm{~N} /$ cadastrado \\
\hline & & 2111 & 1985 & FAMS - AI \\
\hline Bartolomeu . Gusmão n 180 & Enseada & 13588 & 1951 & FAMS $=$ AP \\
\hline & & 16086 & 1983 & N/ cadastrado \\
\hline Saldanha da Gama n 2/4 & Canto do mar & 12774 & 1971 & FAMS - AG \\
\hline & & 21098 & 1971 & $\mathrm{~N} /$ cadastrado \\
\hline Saldanha da Gama n 8/10 & Itá & 5962 & 1952 & N/ cadastrado \\
\hline & & 41545 & 1962 & $\mathrm{~N} /$ cadastrado \\
\hline Saldanha da Gama n 67 & Pontal da Barra & 5477 & 1986 & $\mathrm{~N} /$ encontrado \\
\hline Saldanha da Gama n 69 & comercio & 4272 & 1943 & N/ encontrado \\
\hline & & 7639 & 1943 & N/ encontrado \\
\hline Saldanha da Gama n 71 & Cabo frio & 27457 & 1964 & N/ encontrado \\
\hline Saldanha da Gama n 72 & Golden Ocean & 20192 & 1973 & N/ encontrado \\
\hline & Golden ucean & 20145 & 1951 & $\mathrm{~N} /$ encontrado \\
\hline Saldanha da Gama n 84 & Navegantes & 17798 & 1984 & N/ cadastrado \\
\hline Saldanha da Gama n 96 & Jardins da Grécia & não cadas & do nas & is rosas \\
\hline & & 11365 & 1957 & FAMS - AG \\
\hline Saldanha da Gama n 121 & Mont Blanc & 22969 & 1964 & $\mathrm{~N} /$ encontrado \\
\hline & & 24238 & 1980 & FAMS - Al \\
\hline & & 20461 & 1958 & N/ cadastrado \\
\hline Saldanha da Gama n 126/127 & comercial & 13959 & 1963 & N/ cadastrado \\
\hline & & 12126 & 1976 & FAMS - Al \\
\hline & & 12973 & 1966 & $\mathrm{~N} /$ cadastrado \\
\hline Saldanha da Gama n 137 & & 28828 & 1989 & $\mathrm{~N} /$ cadastrado \\
\hline & & \begin{tabular}{|c|}
14938 \\
\end{tabular} & 1976 & \\
\hline Saldanha da Gama n 141 & Solmar & anexado ao 67116 & 2003 & FAMS - Al \\
\hline & & \begin{tabular}{|l|}
26091 \\
\end{tabular} & 1960 & FAMS - AI \\
\hline Saldanha da Gama n 194 & Irmaos Castro Conde & 6885 & 1959 & N/ cadastrado \\
\hline
\end{tabular}


Nem todos os processos puderam ser consultados pois, depois de solicitados, nem sempre eram encontrados nos arquivos mas, uma grande quantidade pode ser examinada confirmando que a maioria dos edifícios da Ponta da Praia foram construídos entre 1950-1980 e encontram-se apoiados em sapatas.

Além do tipo de fundação, outro ponto importante pode ser notado. Existem vários prédios principalmente na "Faixa Crítica", que possuem mais de um laudo técnico, avaliando a situação do edifício, destacando os danos internos causados pelos recalques diferenciais e a execução de algum tipo de reforço na fundação.

Nos edifícios da Ponta da Praia, não foram encontrados laudos técnicos referentes a problemas de desaprumo. Isso ajuda a levar adiante a idéia que os recalques na Ponta da Praia são bem menores, não só pelo fato de não serem perceptíveis a olho nu, mas também por nenhum prédio apresentar registro de problemas quanto a isso.

Para facilitar a visualização dos edifícios da orla da Ponta da Praia, o bairro foi dividido em duas vistas, panorâmica 1 e panorâmica 2, destacados na foto 16.

A foto 17, panorâmica1, retrata os edifícios da região mais densificada, ou seja, onde os edifícios foram construídos lado a lado, assim como na "faixa crítica". $\mathrm{Na}$ panorâmica 2, o cenário é um pouco diferente já que quadras inteiras são ocupadas por clubes e museus da cidade, se tratando de edificações de pequeno porte, dois ou três pavimentos, por esse motivo a panorâmica 2 não foi detalhada nesse trabalho. As figuras 19 a 25 e fotos de 18 a 24, mostram as quadras da panorâmica 1, uma a uma; dessa maneira, pode-se verificar a inclinação mínima ou a inexistência de inclinação dos edifícios. 


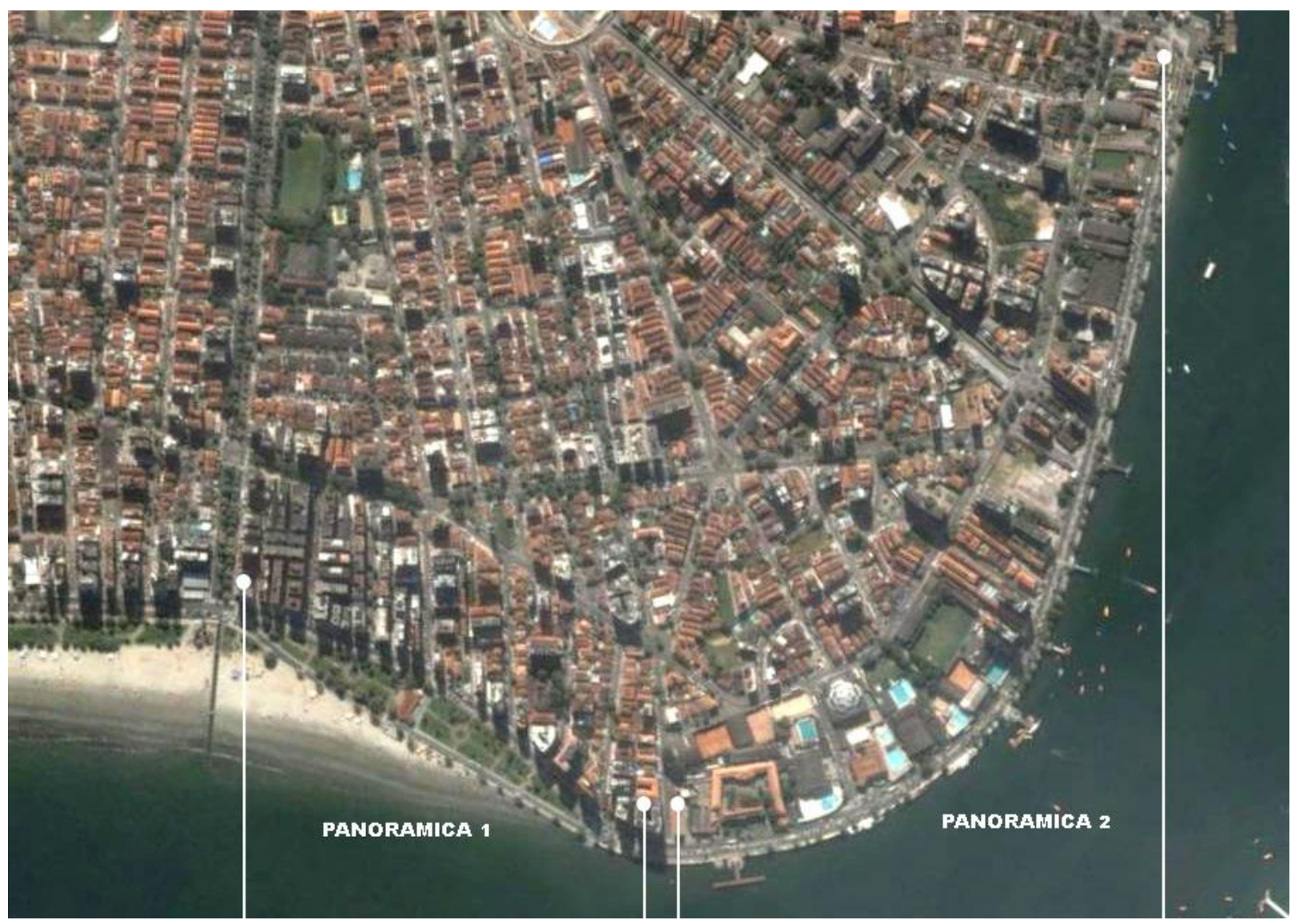

Foto 16 - Bairro da Ponta da Praia em duas vistas (Fonte: Adaptado de Google Earth, março, 2009)

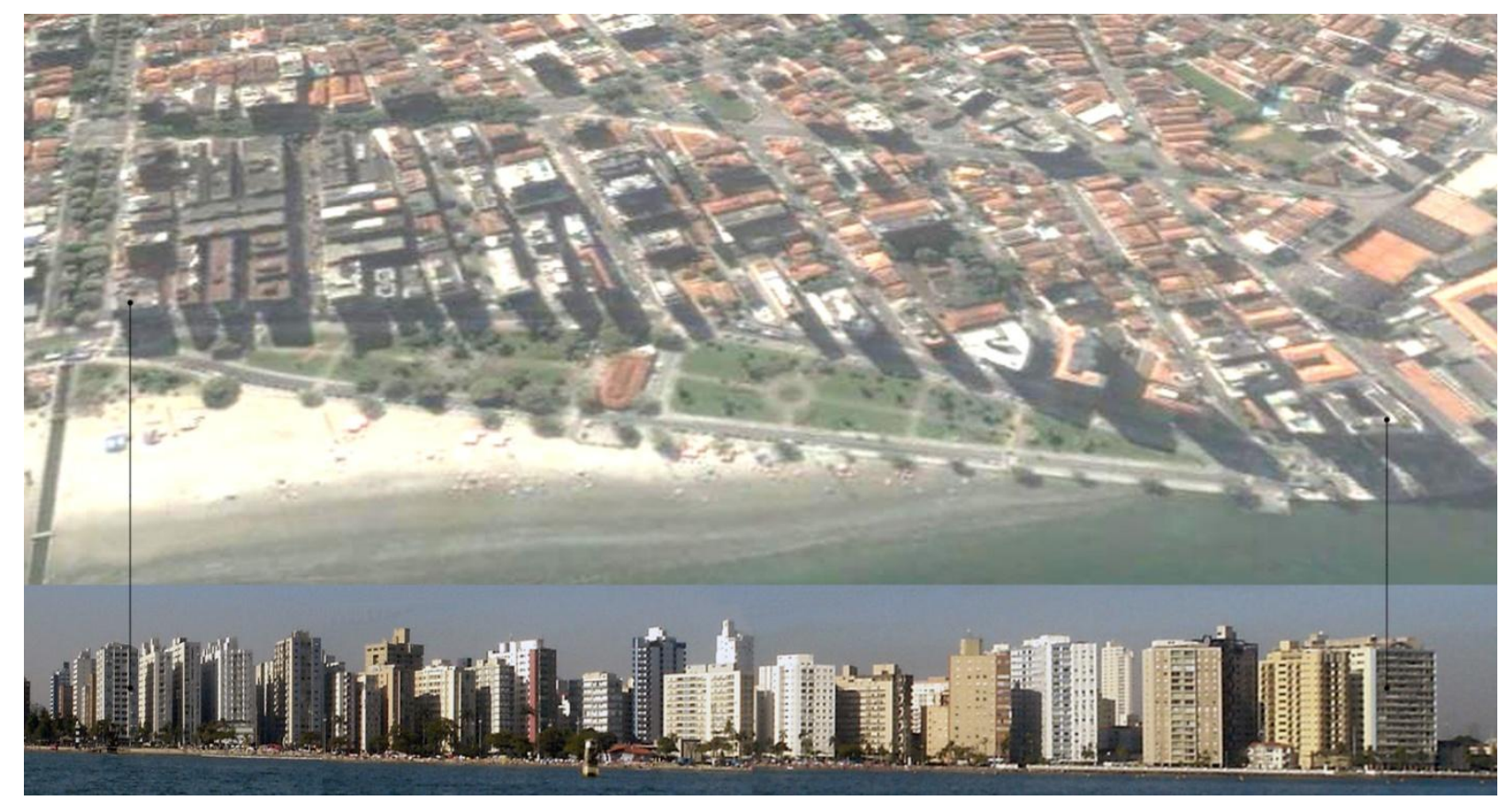

Foto 17 - Panorâmica 1 - Vista dos edifícios trecho mais densificado da Ponta da Praia. (Foto Montagem -Fonte: autora, 2008) 


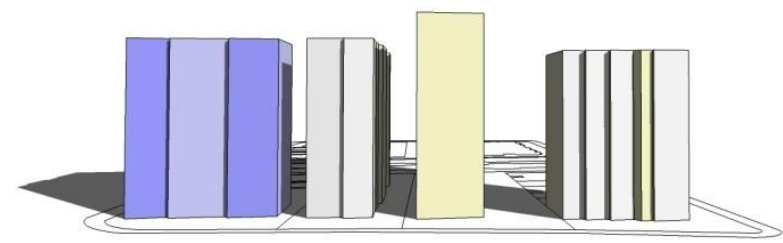

Figura 19 - Esquema de posicionamento dos edifícios da quadra 37

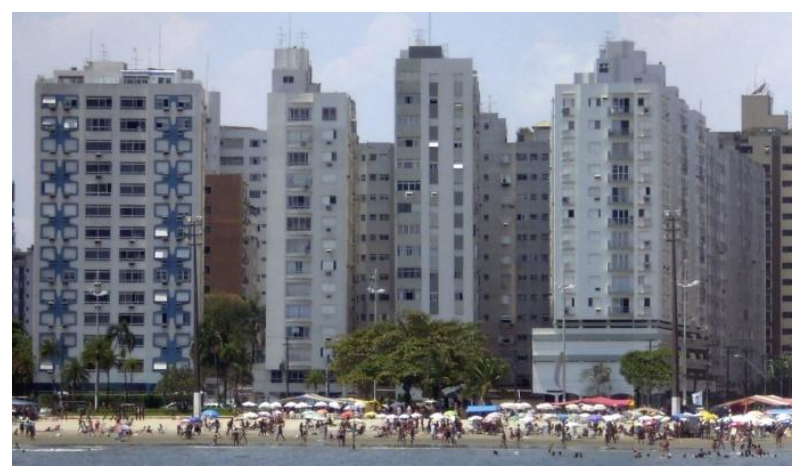

Foto 18 - Quadra 37

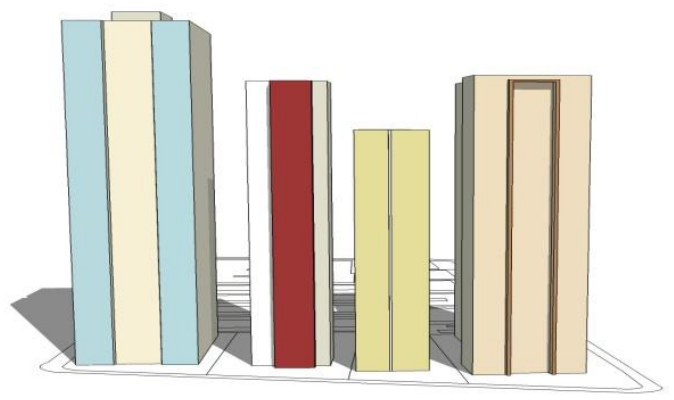

Figura 20 - Esquema de posicionamento dos edifícios da quadra 38

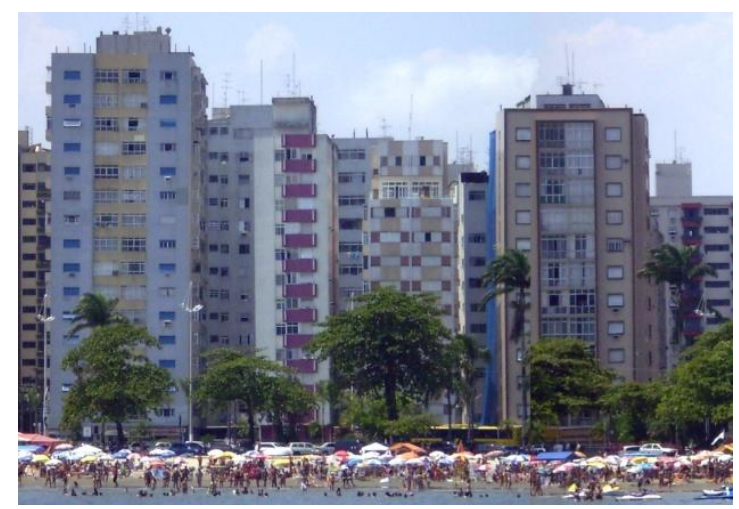

Foto 19 - Quadra 38 


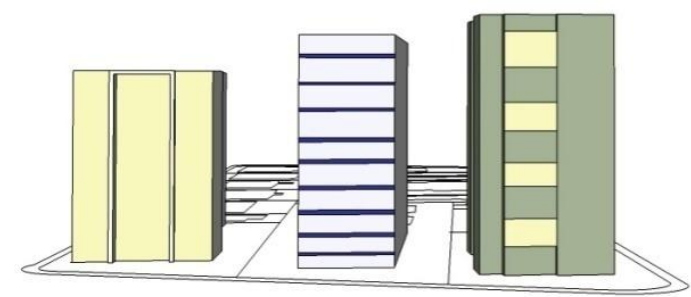

Figura 21 - Esquema de posicionamento dos edifícios da quadra 39

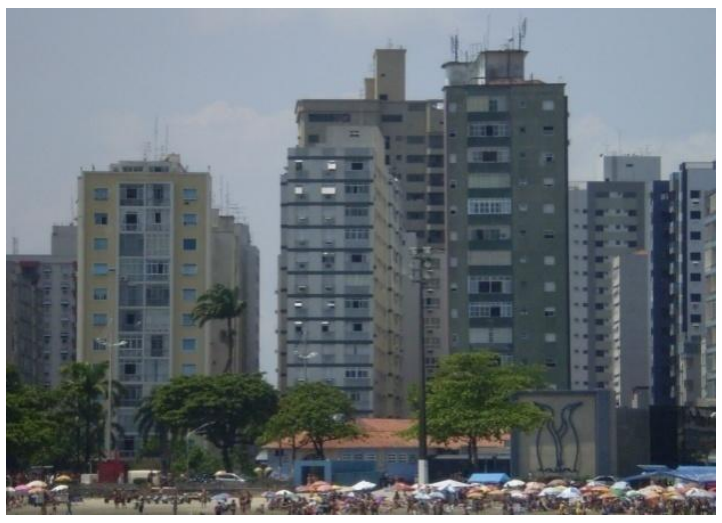

Foto 20 - Quadra 39

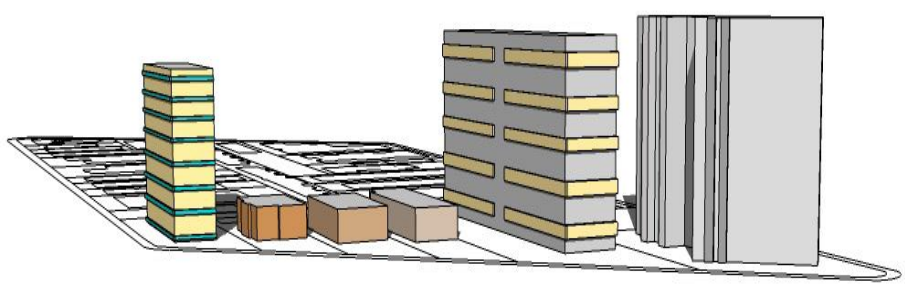

Figura 22 - Esquema de posicionamento dos edifícios da quadra 40

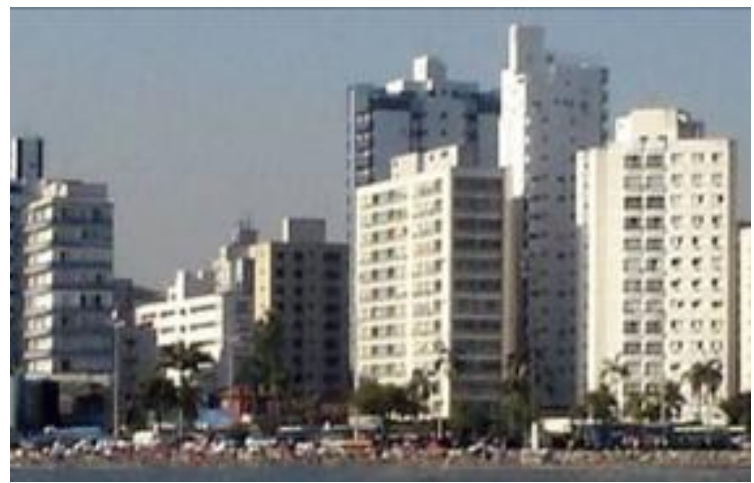

Foto 21 - Quadra 40 


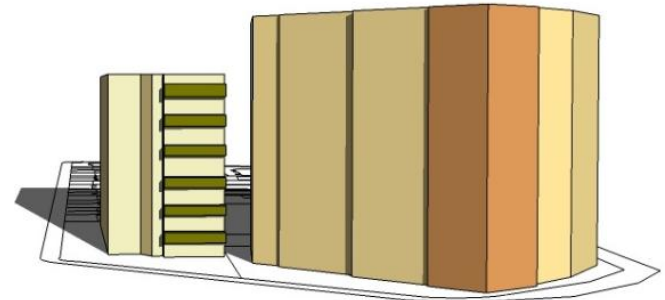

Figura 23 - Esquema de posicionamento dos edifícios da quadra 41

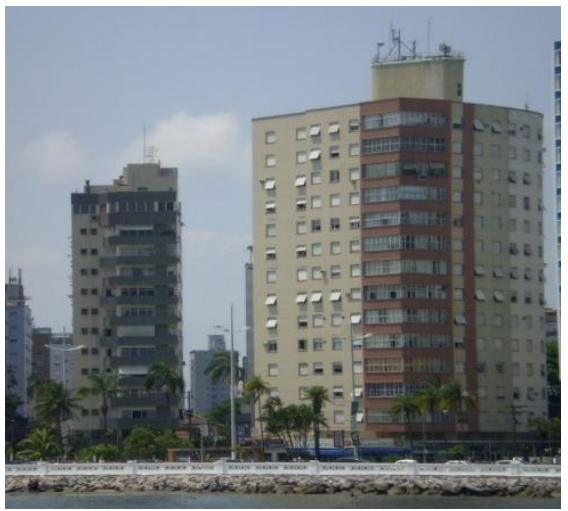

Foto 22 - Quadra 41

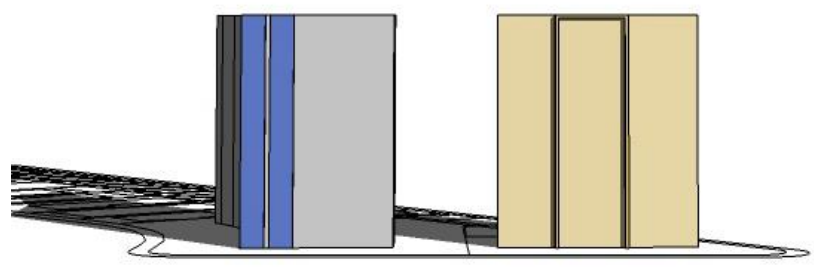

Figura 24 - Esquema de posicionamento dos edifícios da quadra 42

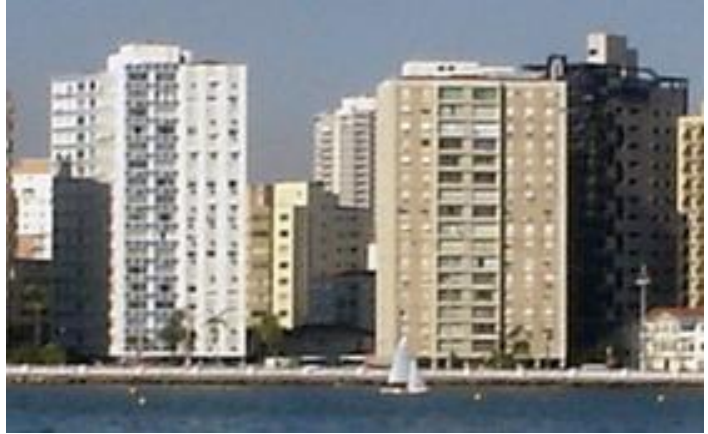

Foto 23 - Quadra 42 


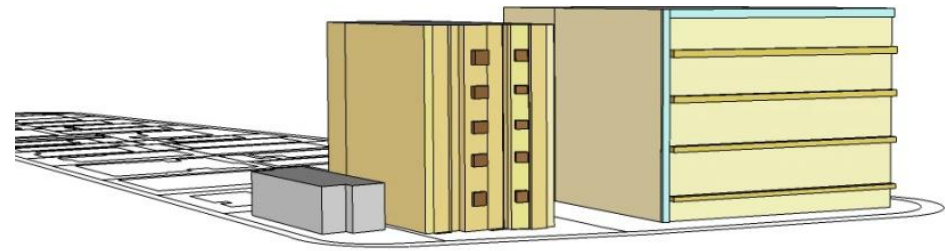

Figura 25 - Esquema de posicionamento dos edifícios da quadra 43

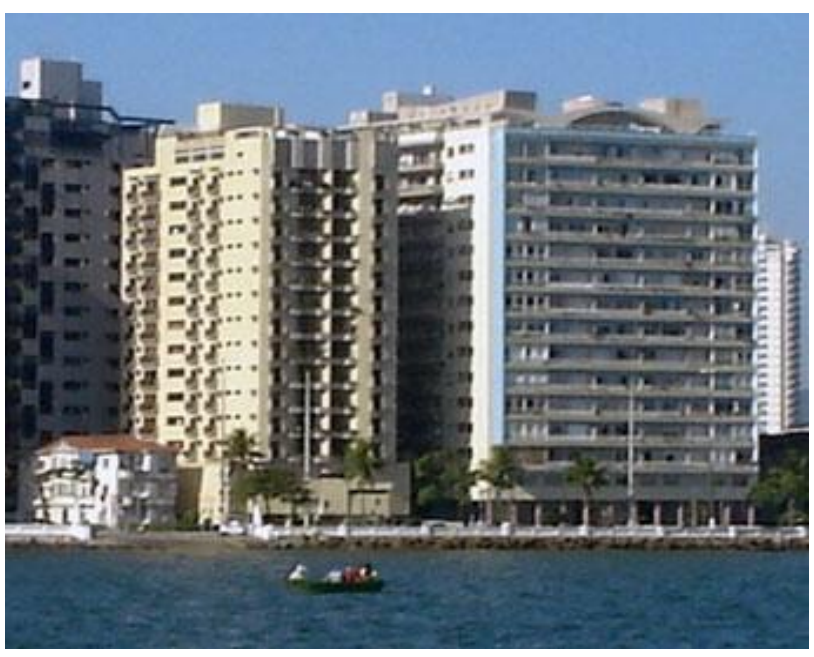

Foto 24 - Quadra 43 


\section{CAPÍTULO IV - INTERPRETAÇÃO DE ENSAIOS E PREVISÃO DE RECALQUES NA CIDADE DE SANTOS}

\section{1 - ANÁLISE COMPARATIVA DE SONDAGENS DE SIMPLES RECONHECIMENTO, COM MEDIDAS DE NSPT}

\subsection{1 - Sondagens coletadas e analisadas}

Foram coletadas mais de 250 sondagens de simples reconhecimento realizadas na cidade de Santos no decorrer dos anos. Essas sondagens foram a base para obter dados e traçar os perfis do subsolo Santista.

Empresas que executaram e ainda executam sondagens na região, foram contatadas. A empresa Engesolos concedeu uma autorização para pesquisar em seus arquivos, sondagens realizadas na cidade ao longo dos anos. Outras empresas enviaram o material por e - mail. A Zaclis Falconi, especializada em projetos de fundação também disponibilizou as sondagens de suas obras na cidade.

Os estudos e análises de sondagens se concentraram na região da faixa crítica, quadras 19 a 36 e na Ponta da Praia quadras 37 a 49, (ver foto 11). O objetivo foi separar uma sondagem representativa por quadra, comparar os valores de NSPT e espessura das primeiras camadas de areia e argila (SFL) e depois retraçar as seções geológicas das regiões estudas.

As sondagens foram separadas por trechos: canal 3 - canal 4 (Bairro Boqueirão); canal 4 - canal 5 (Bairro Embaré); canal 5 - canal6 (Bairro Aparecida) e Ponta da Praia (canal 6 - balsa). Para cada trecho foram selecionadas oito sondagens de maneira que a localização não fosse repetida; dessa forma, foi possível abranger toda extensão da "Faixa Crítica" até a Ponta da Praia. Na planta da figura 30, foram locadas todas as sondagens e ensaios do cone coletados durante a pesquisa, em destaque estão as sondagens de referência que foram a base para a elaboração dos perfis geotécnicos mostrados na figuras 45 e 46, e dos valores apresentados nas 
tabelas VI, VII, VIII e IX e para a. As figuras 26, 27, 28 e 29, mostram ainda uma sondagem representativa de cada trecho analisado.

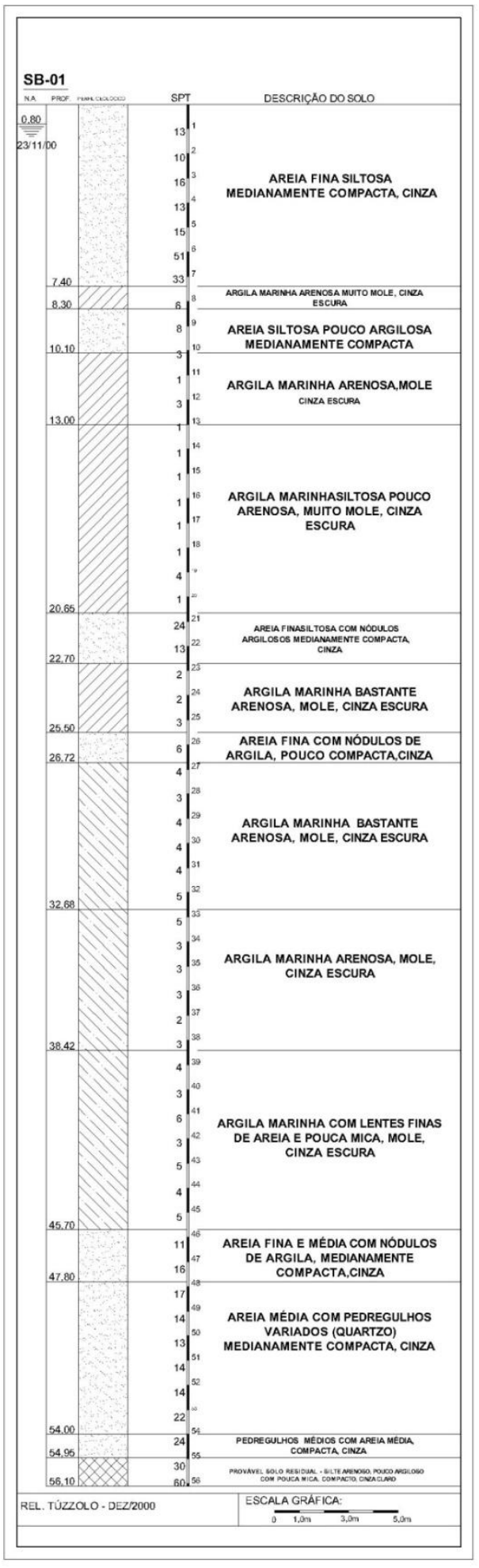

Figura 26 - sondagem representativa canal $3-4$

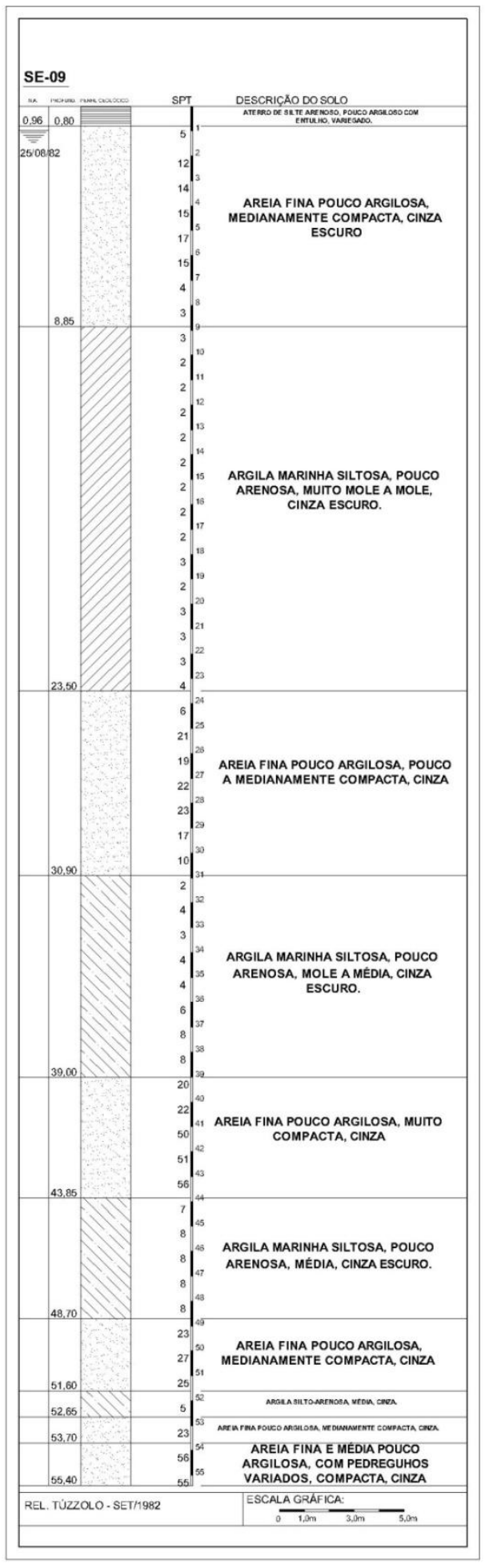

Figura 27 - sondagem representativa canal 4 - 5 


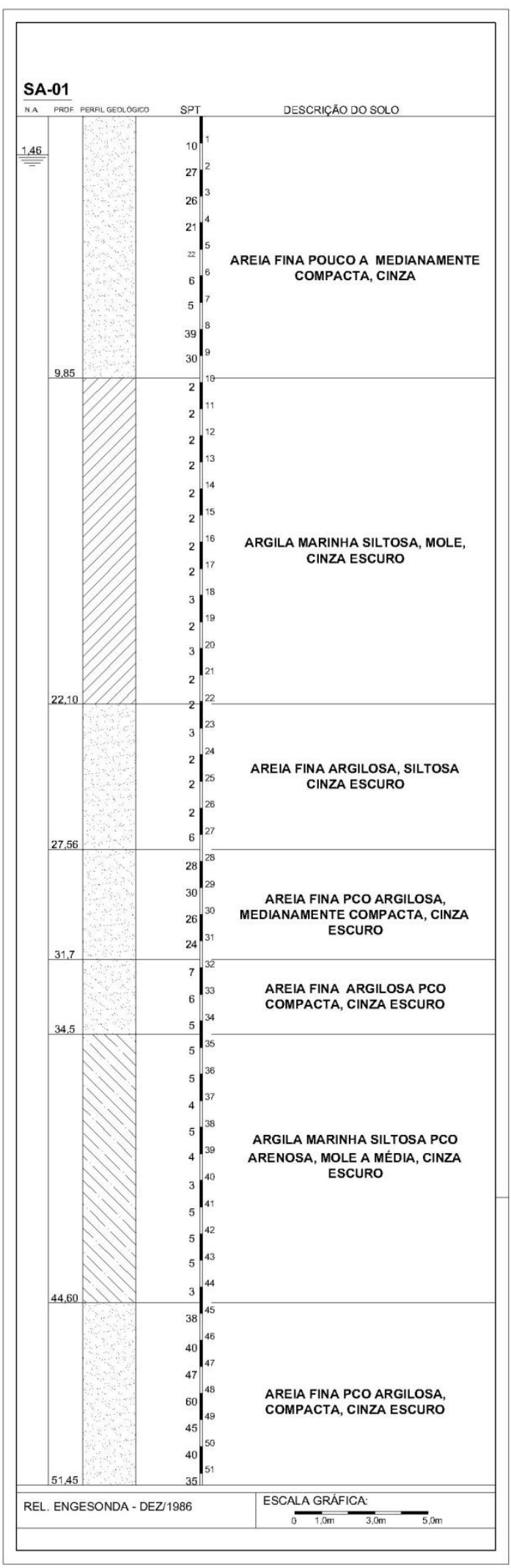

Figura 28 - Sondagem representativa canal 5 - 6

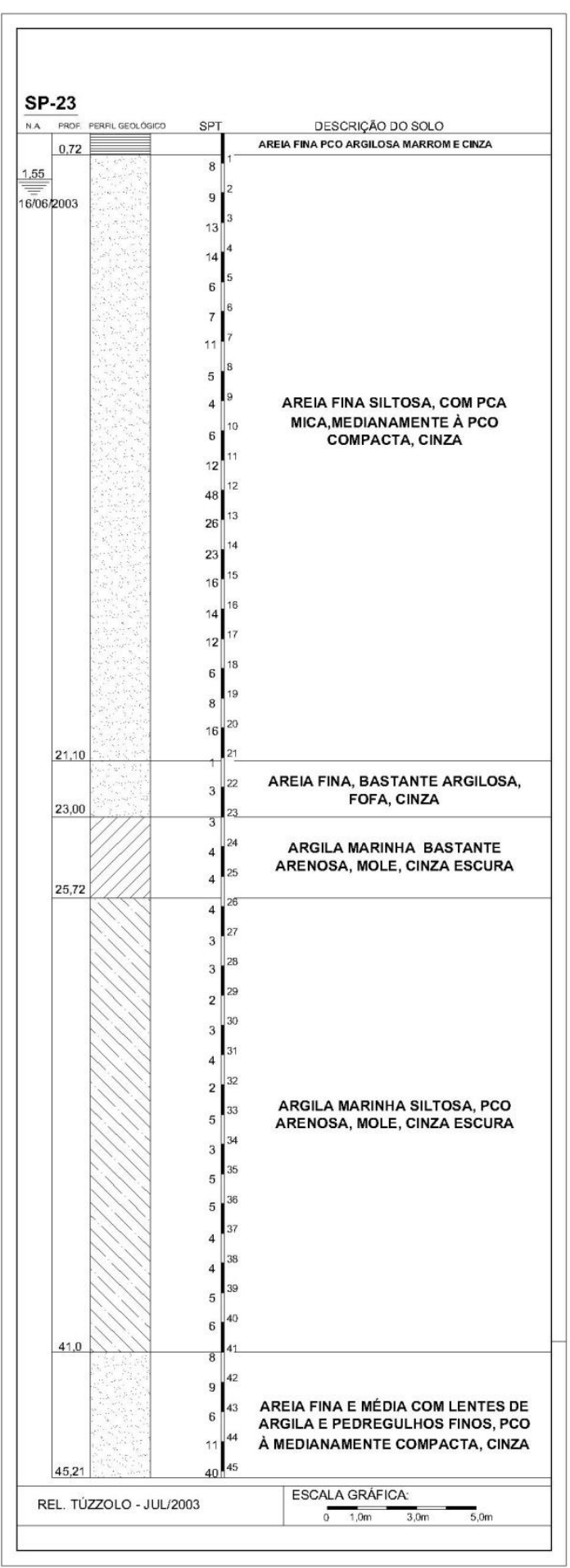

Figura 29 - Sondagem representativa Ponta da Praia 

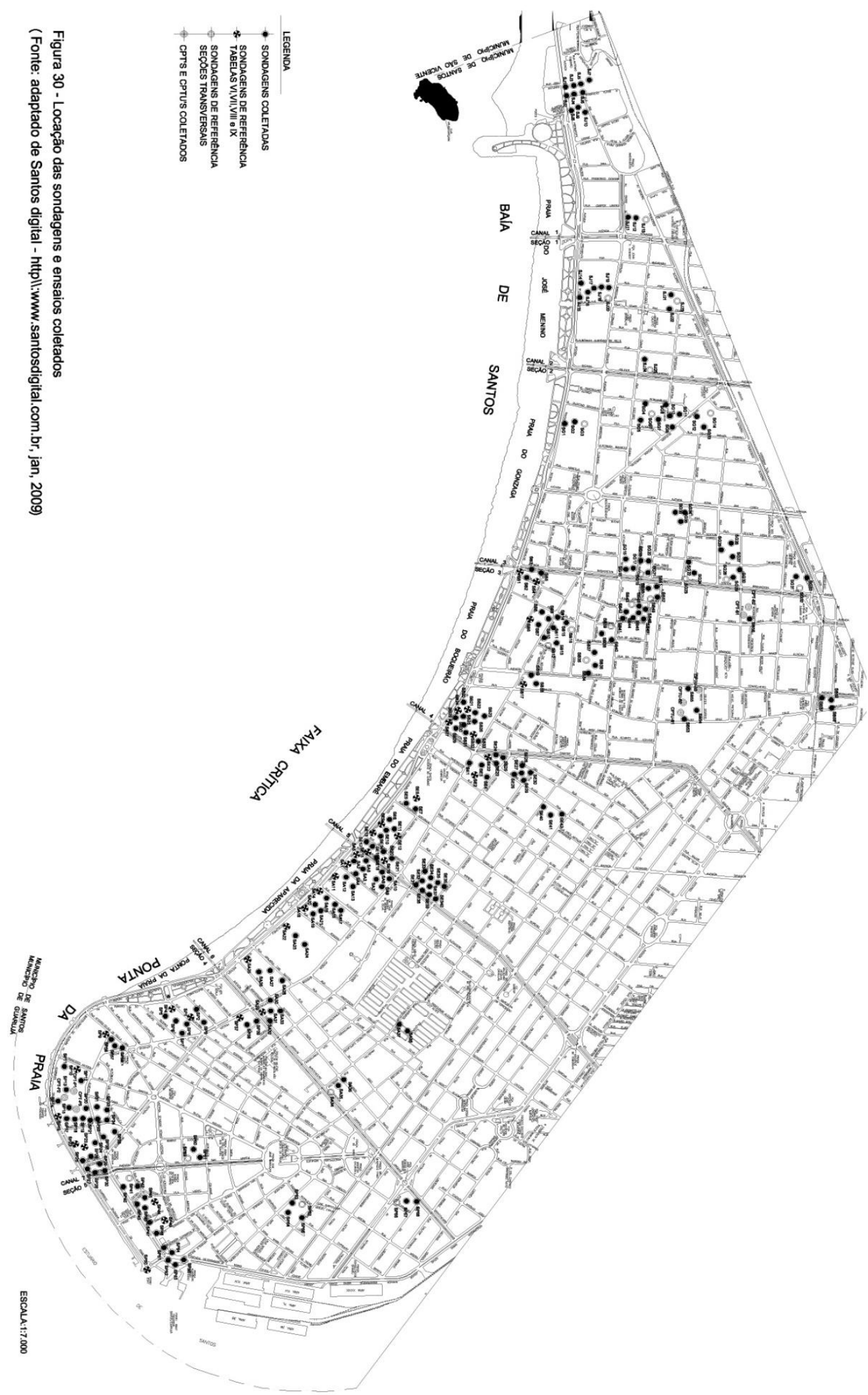

Figura 30 - Locação das sondagens e ensaios coletados 


\subsection{2 - Valores de $\mathbf{N}_{\text {spt médio }}$ para as sondagens de referência}

As tabelas VI, VII, VIII e IX apresentam os valores dos NSPT médios, bem como as espessuras da primeira camada de areia e da primeira camada de argila (SFL) das sondagens selecionadas.

Tabela VI - Análise das sondagens no trecho: Canal 3 - Canal 4

\begin{tabular}{|c|c|c|c|c|c|c|c|c|}
\hline \multicolumn{7}{|c|}{ Canal 3 - Canal 4 (Bairro Boqueirão) } \\
\hline Sondagem & SB01 & SB04 & SB06 & SB17 & SB21 & SB24 & SB27 & SB32 \\
\hline Espessura camada de areia (m) & 10,0 & 10,0 & 12,5 & 11,0 & 12,0 & 7,0 & 11,0 & 12,5 \\
\hline $\begin{array}{c}\text { Espessura camada de argila } \\
\text { SFL (m) }\end{array}$ & 13,0 & 10,0 & 13,0 & 16,0 & 17,0 & 23,0 & 16,0 & 14,0 \\
\hline$N_{\text {SPT }}$ médio camada de areia & 17,0 & 14,0 & 14,0 & 12,0 & 14,0 & 23,0 & 10,0 & 25,0 \\
\hline $\begin{array}{c}N_{\text {SPT }} \text { médio camada de argila } \\
\text { (SFL) }\end{array}$ & 1,7 & 1,9 & 2,5 & 1,6 & 2,4 & 1,5 & 1,0 & 1,2 \\
\hline
\end{tabular}

Tabela VII - Análise das sondagens trecho: Canal 4 - Canal 5

\begin{tabular}{|c|c|c|c|c|c|c|c|c|}
\hline \multicolumn{7}{|c|}{ Canal 4 - Canal 5 (Bairro Embaré) } \\
\hline Sondagem & SE02 & SE06 & SE09 & SE12 & SE13 & SE15 & SE19 & SE22 \\
\hline $\begin{array}{c}\text { Espessura camada de areia (m) } \\
\text { Espessura camada de argila } \\
\text { SFL (m) }\end{array}$ & 9,0 & 8,5 & 8,5 & 9,5 & 9,0 & 9,0 & 9,0 & 10,5 \\
\hline$N_{\text {SPT }}$ médio camada de areia & 16,0 & 12,0 & 15,0 & 14,0 & 13,0 & 11,0 & 14,0 & 16,0 \\
\hline $\begin{array}{c}N_{\text {SPT }} \text { médio camada de argila } \\
(\mathrm{SFL})\end{array}$ & 1,3 & 1,3 & 1,8 & 1,8 & 2,2 & 3,0 & 1,0 & 1,8 \\
\hline
\end{tabular}


Tabela VIII - Análise das sondagens trecho: Canal 5 - Canal 6

\begin{tabular}{|c|c|c|c|c|c|c|c|c|}
\hline \multicolumn{7}{|c|}{ Canal 5 - Canal 6 (Bairro Aparecida) } \\
\hline Sondagem & SA01 & SA05 & SA11 & SA14 & SA18 & SA22 & SA25 & SA29 \\
\hline $\begin{array}{c}\text { Espessura camada de areia (m) } \\
\text { Espessura camada de argila } \\
\text { SFL (m) }\end{array}$ & 9,5 & 10,5 & 10,0 & 8,0 & 7,0 & 8,5 & 9,5 & 10,0 \\
\hline $\begin{array}{c}\text { N } \\
\text { SPT médio camada de areia }\end{array}$ & 20,5 & 16,5 & 22,0 & 15,5 & 11,0 & 11,5 & 13,5 & 12,5 \\
\hline$N_{\text {SPT médio camada de argila }}$ (SFL) & 2,4 & 1,6 & 1,6 & 2,0 & 1,2 & 1,0 & 1,7 & 2,0 \\
\hline
\end{tabular}

Tabela IX - Análise das sondagens da Ponta da Praia

\begin{tabular}{|c|c|c|c|c|c|c|c|c|c|c|c|}
\hline \multicolumn{7}{|c|}{ Canal 6-Canal 7 (Ponta da Praia) } \\
\hline Sondagem & SP37 & SP01 & SP04 & SP09 & SP10 & SP16 & SP22 & SP23 & SP44 & SP49 & SP50 \\
\hline $\begin{array}{c}\text { Espessura } \\
\text { camada de } \\
\text { areia (m) }\end{array}$ & 10 & 12 & 12,5 & 16,5 & 17,5 & 21,5 & 24,5 & 23,0 & 21,0 & 20,5 & 17,5 \\
\hline $\begin{array}{c}\text { Espessura } \\
\text { camada de } \\
\text { argila SFL (m) }\end{array}$ & 9,0 & 10,0 & 7,0 & 19,0 & 13,0 & 8,0 & 8,0 & 10,0 & 9,0 & 5,0 & 9,0 \\
\hline $\begin{array}{c}\text { N } \\
\text { camad médio } \\
\text { areia }\end{array}$ & 12,5 & 10,0 & 15,6 & 12,5 & 9,0 & 11,0 & 7,5 & 11,0 & 7,5 & 10,5 & 7,5 \\
\hline $\begin{array}{c}\text { N } \\
\text { cam médio } \\
\text { argila (SFL) }\end{array}$ & 1,8 & 1,5 & 1,7 & 3,5 & 2,2 & 4,0 & 3,0 & 3,5 & 3,2 & 3,3 & 2,5 \\
\hline
\end{tabular}




\subsection{3 - Análise das sondagens}

Inicialmente foi observado que o aumento da espessura da primeira camada de areia no bairro da Ponta da Praia é bem significativo. Enquanto nos trechos do canal 3 ao canal 6 ela tem em média $10,0 \mathrm{~m}$, variando de 7,0 a 12,50 m, na Ponta da praia chega até mais de $23,0 \mathrm{~m}$, tendo como valor médio 20,0m de espessura.

Com a análise do $\mathrm{N}_{\mathrm{SPT}}$ médio da primeira camada de areia, observa-se que embora a primeira camada de areia da região da Ponta da Praia seja mais espessa, ela possui $\mathrm{N}_{\text {SPT }}$ médio menor que na região comparada. Na "Faixa Crítica", a variação do $\mathrm{N}_{\text {SPT }}$ foi de 9,5 a 20, com valor médio = 14; na Ponta da praia os valores variam entre 7,5 e 16, com NSPT médio = 10 .

Ainda quanto a primeira camada de areia no Bairro da Ponta da Praia, foi notado que sua espessura aumenta gradativamente no sentido canal 6 - canal7, até atingir o valor máximo encontrado, cerca de 23,0 a 24,0m na região próxima à quadra 46, depois ela volta a diminuir, retornando aos $17,0 \mathrm{~m}$ perto da quadra 49 , tendendo a desaparecer a medida que se aproxima do Guarujá.

Para a camada de argila SFL constatou - se que na Ponta da Praia os valores de $\mathrm{N}_{\text {SPT }}$ médio variam de 2 a 4, e para a "Faixa Crítica" os números ficaram entre 1 e 3. Foi observado também que à medida que se aproxima do canal 7, sentido Guarujá, as camadas de argila SFL e AT não se encontram mais entremeadas por camadas de areias

\section{2 - SONDAGENS PROFUNDAS}

Até pouco tempo, era comum na cidade de Santos, quase todas as sondagens serem executadas até 50 a $55 \mathrm{~m}$, que é a profundidade na qual costuma-se encontrar o solo residual.

Porém, avanço das construções de grande porte na cidade, propiciou um maior número de investigações geotécnicas e fêz necessário aprofundar as sondagens, dada a grandeza das cargas nas fundações. Com isso foram encontradas camadas 
de argila profundas, abaixo dos $55-60 \mathrm{~m}$, e a presença do solo residual abaixo dos 70-80m de profundidade

Essas argilas apresentam $\mathrm{N}_{\mathrm{SPT}}$ 's relativamente elevados (6 a13 golpes), cores predominantemente cinza-claras, mas ocorrendo também em tons avermelhados, podendo tratar-se de solos residuais ou sedimentos continentais. $\mathrm{Na}$ Baixada Santista é comum ocorrência de sedimentos continentais sobre solo residual, mas é fato novo sua possível existência ao longo da orla Praiana de Santos. Outro ponto a ser destacado, refere-se à posição do topo rochoso que, na "faixa crítica", pode estar abaixo dos $80 \mathrm{~m}$ de profundidade, ver figura 43.

Como exemplo, tem-se o caso de duas sondagens executadas recentemente na cidade de Santos (2008). A primeira, próxima ao canal 4 e à praia, com aproximadamente $70 \mathrm{~m}$ de profundidade (figura31), revelou camadas de argila muito profundas, avermelhadas, a mais de $55 \mathrm{~m}$, diferente das ATs. Tratar-se-iam de sedimentos continentais ou de solos residuais. A segunda sondagem, próxima ao canal 6, um pouco mais afastada da praia (figura 32), camadas de argila avermelhadas, também foram observadas. As fotos 25, 26 e 27, mostram as argilas retiradas do terreno próximo ao canal 4, a diferentes profundidades. Essas amostras foram obtidas durante a execução da fundação de um edifício, nesse caso, foram utilizadas estacas escavadas de grande diâmetro, com uso de lama bentonítica, o diâmetro da estaca de onde as amostras foram retiradas foi de $90 \mathrm{~cm}$. A foto 28 mostra a argila avermelhada encontrada na sondagem próxima ao canal 6 , obtida durante a execução da sondagem. 


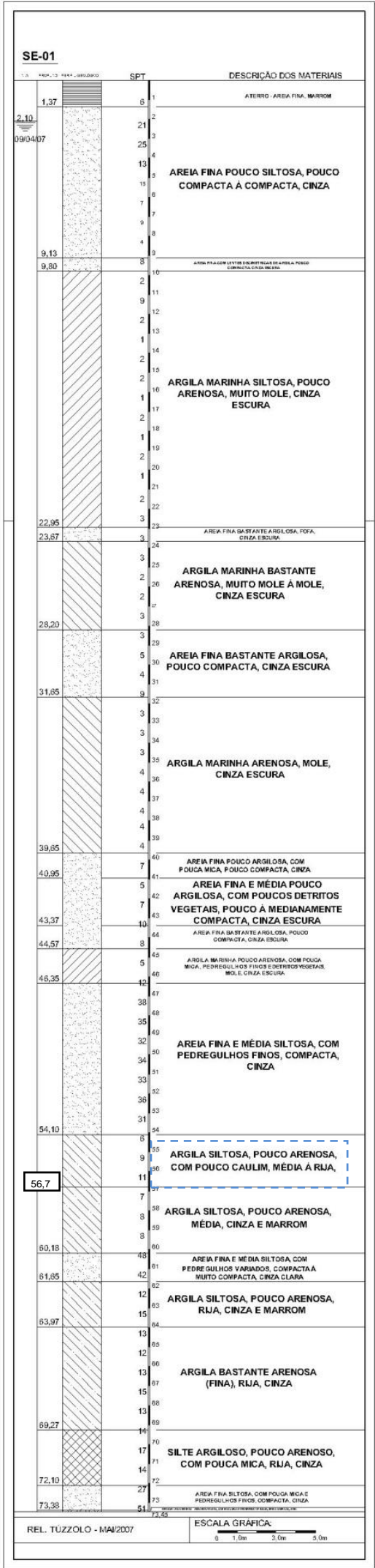

Figura 31 - Sondagem representativa próxima ao canal 4

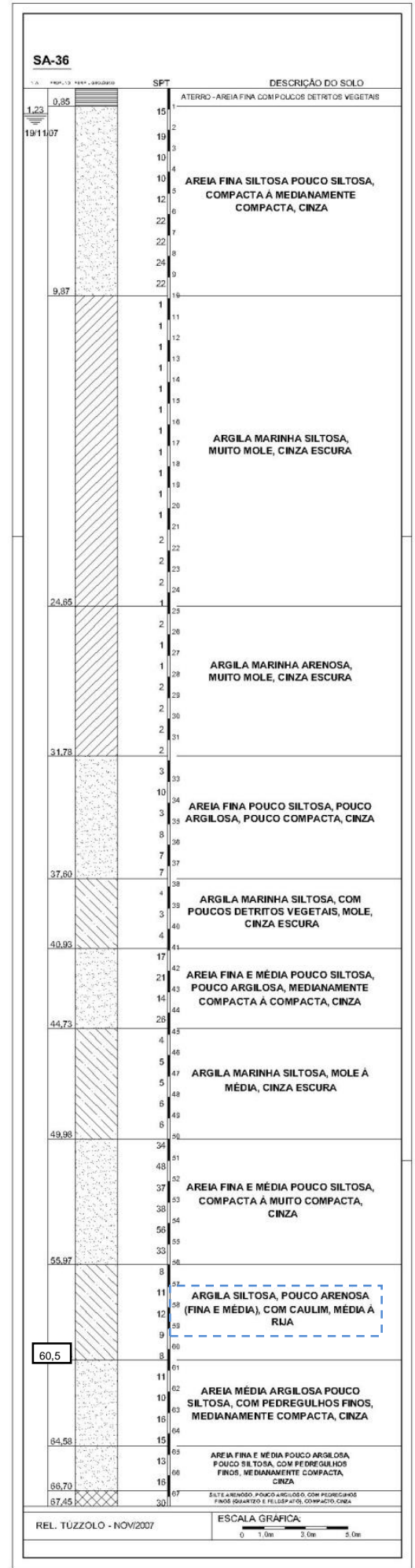

Figura 32 - Sondagem representativa próxima ao canal 6 


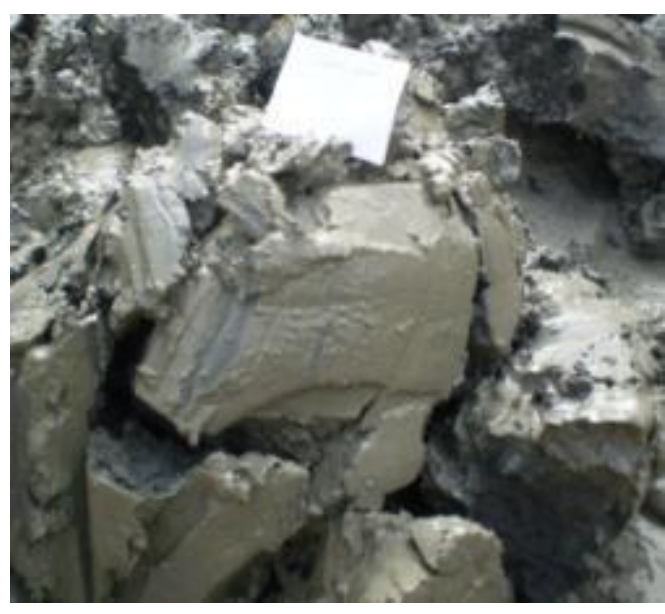

Foto 25 - Argila SFL aos 10m de profundidade

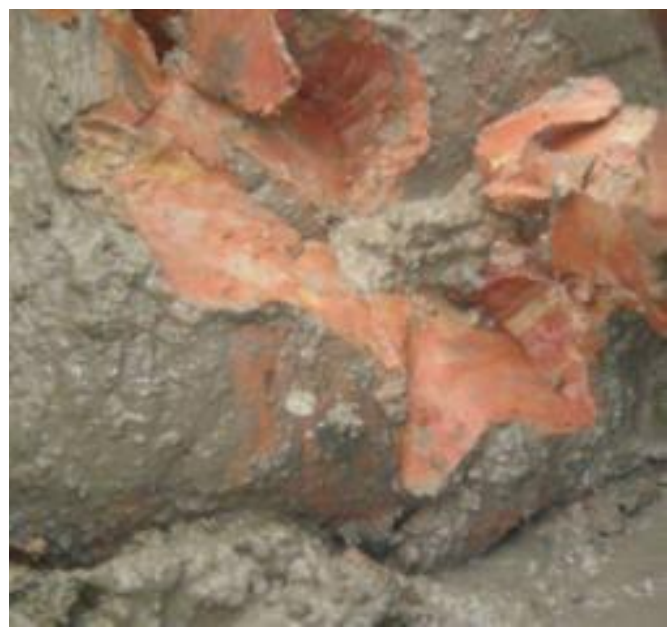

Foto 27 - Argila avermelhada aos $56,0 \mathrm{~m}$ de profundidade

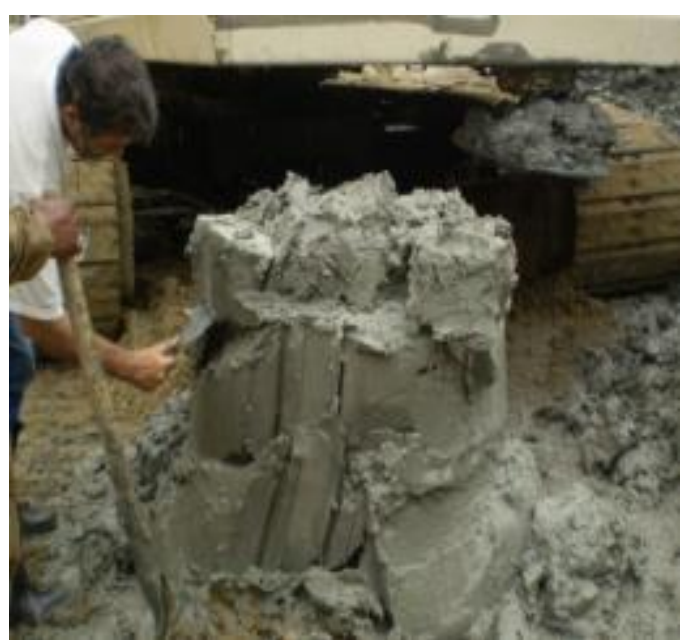

Foto 26 - Argila A.T aos $42 \mathrm{~m}$ de profundidade

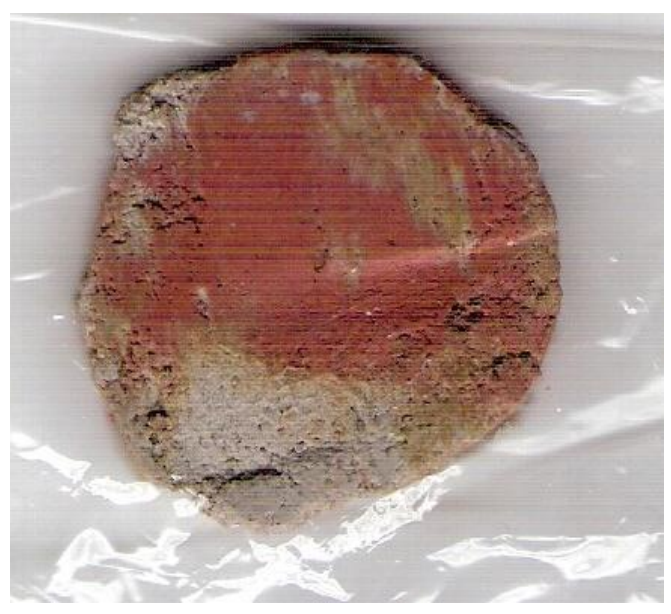

Foto 28 - Argila avermelhada próxima ao canal 6 


\section{3 - RESULTADOS DE ENSAIOS DO CONE (CPT e CPTU) NA CIDADE DE SANTOS}

\subsection{1 - Ensaios analisados}

Além dos valores de $\mathrm{N}_{\text {SPT }}$ das diversas sondagens analisadas, ensaios de CPT (Cone Penetration Test) e CPTU (Piezocone Penetration Test), que medem a resistência de ponta do solo, comprovaram que a primeira camada de areia da Ponta da Praia é menos resistente que na "Faixa Crítica".

Para efeito de comparações, foram analisados resultados de ensaios CPTs, realizado na Orla do Bairro da Ponta da Praia, e CPTs e CPTUs, realizados no Bairro do Boqueirão, próximo à região da "Faixa Crítica".

Os ensaios CPTs da Ponta da Praia foram realizados em 1978, durante a construção do Clube Saldanha da Gama, quadra 45, e foi cedido pela Engesolos. Os ensaios CPTs próximos à "Faixa Crítica" foram realizados pela PTS Pesquisas Tecnológicas do solo em 1997, para a construção de um edifício residencial. Já os CPTUs foram realizados durante a construção de um dos edifícios da Universidade Santa Cecília e os resultados foram divulgados por Oliveira (2000).

As figuras 33, 34 e 35 (a, b, c e d), mostram a localização e o resultado dos ensaios de CPTUs e CPTs. As sondagens referentes a cada ensaio estão no anexos " $A$ " e "D".

Tanto no ensaio CPT quanto no ensaio CPTU, é possível obter a resistência à penetração de ponta e a resistência por atrito lateral do solo. A principal diferença entre os dois ensaios é que no CPTU é possível medir também a pressão neutra durante a cravação do cone.

Os CPTUs e CPTs realizados no bairro do Boqueirão foram executados até 20 e 30,0m, atingindo a camada de argila SFL. Os CPTs da Ponta da Praia foram interrompidos aos $13,0 \mathrm{~m}$, não atingindo por inteiro a primeira camada de areia.

Analisando preliminarmente os três ensaios realizados, verifica-se que para a primeira camada de areia, na região próxima à "Faixa Crítica", a resistência de ponta 
(qc) oscilou em média de 10000 a $25000 \mathrm{kPa}$, tanto no CPT quanto no CPTU, enquanto que na Ponta da Praia a resistência de ponta da primeira camada de areia de não passou de $10000 \mathrm{kPa}$.

Quanto à resistência de ponta da primeira camada de argila (SFL), verifica-se nos dois ensaios (CPT e CPTU) que a resistência de ponta apresenta valores bem baixos, em média 500 a $1000 \mathrm{kPa}$.

Em análise aos mesmos CPTUs apresentados abaixo, Massad (2008), obteve para as argilas de $\mathrm{SFL}$ valores de $\mathrm{Bq}=0,4$ a 0,$7 ; \mathrm{qt}=1,0 \mathrm{a} 1,5 \mathrm{MPa}$ e $\mathrm{Rf}=3$ a $4 \%$ destacando que, os resultados dos ensaios do Cone não só confirmaram a classificação genética dos solos da cidade de Santos, como também possibilitaram delimitar com precisão cada camada de solo, graças aos dados contínuos fornecidos ao longo de todo perfil. 


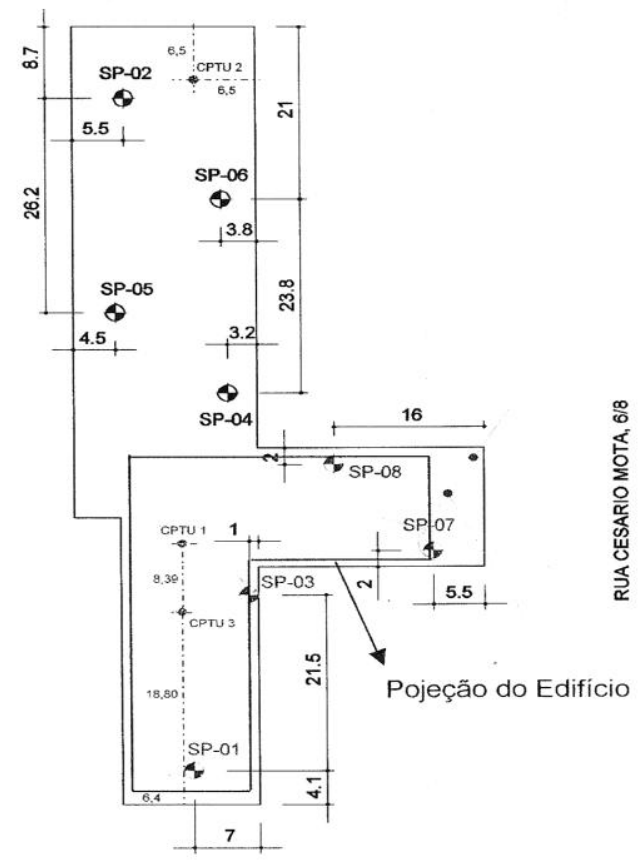

CPTU 1

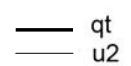

CPTU 2
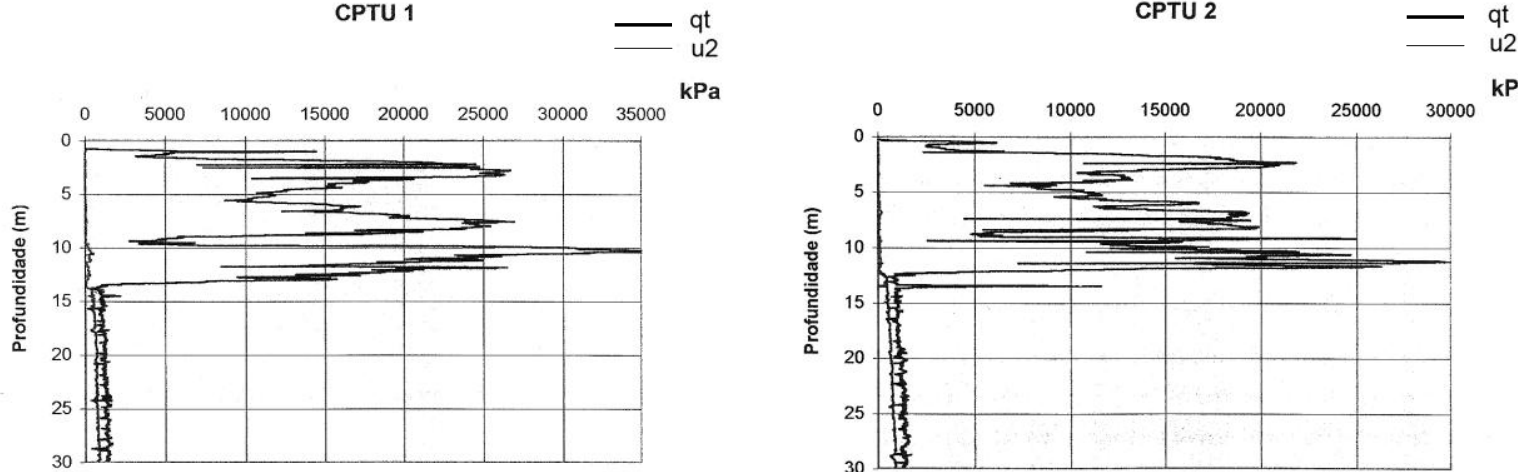

$\mathrm{kPa}$

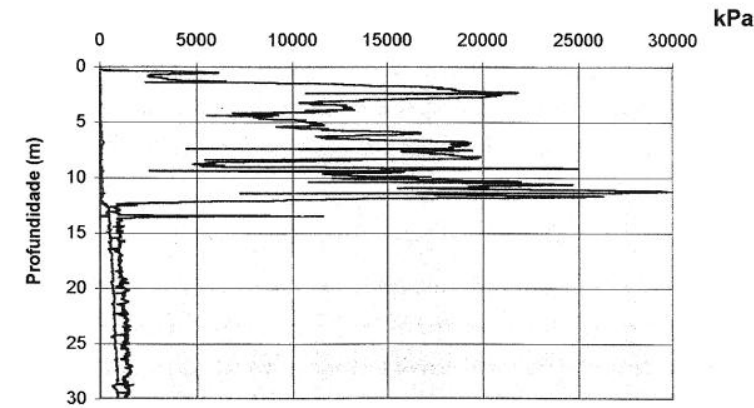

CPTU 3
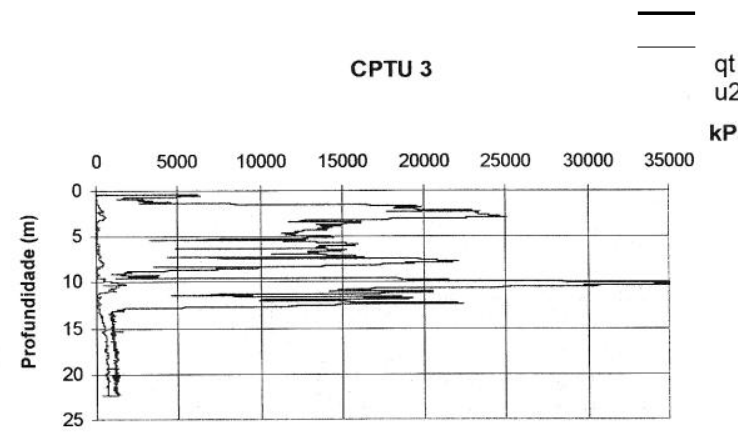

Figura 33 - Locação e resultados dos ensaios de CPTU - Edifíco Unisanta, próximo à "Faixa Crítica" (Fonte: Oliveira, 2000) 

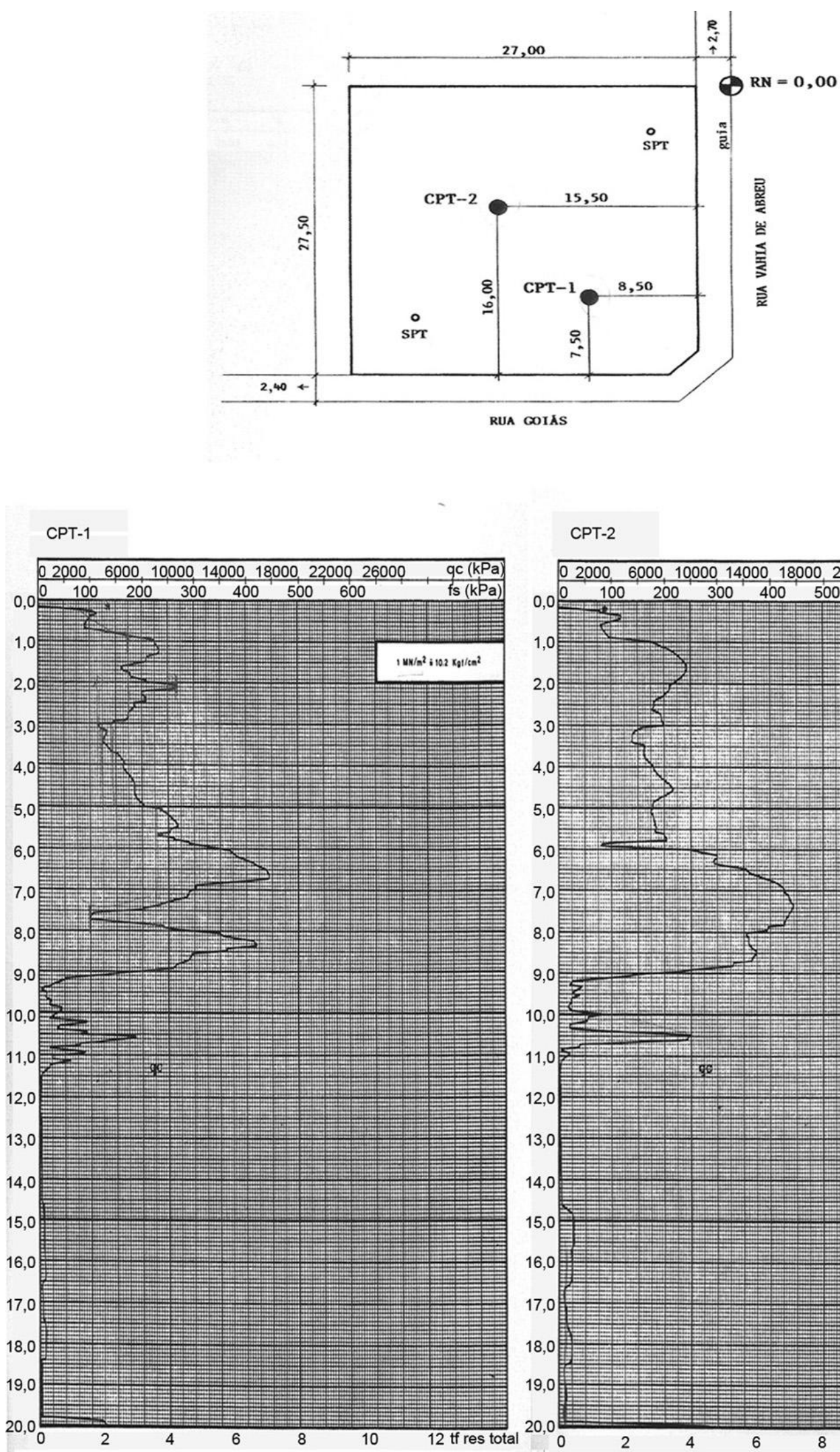

CPT-2

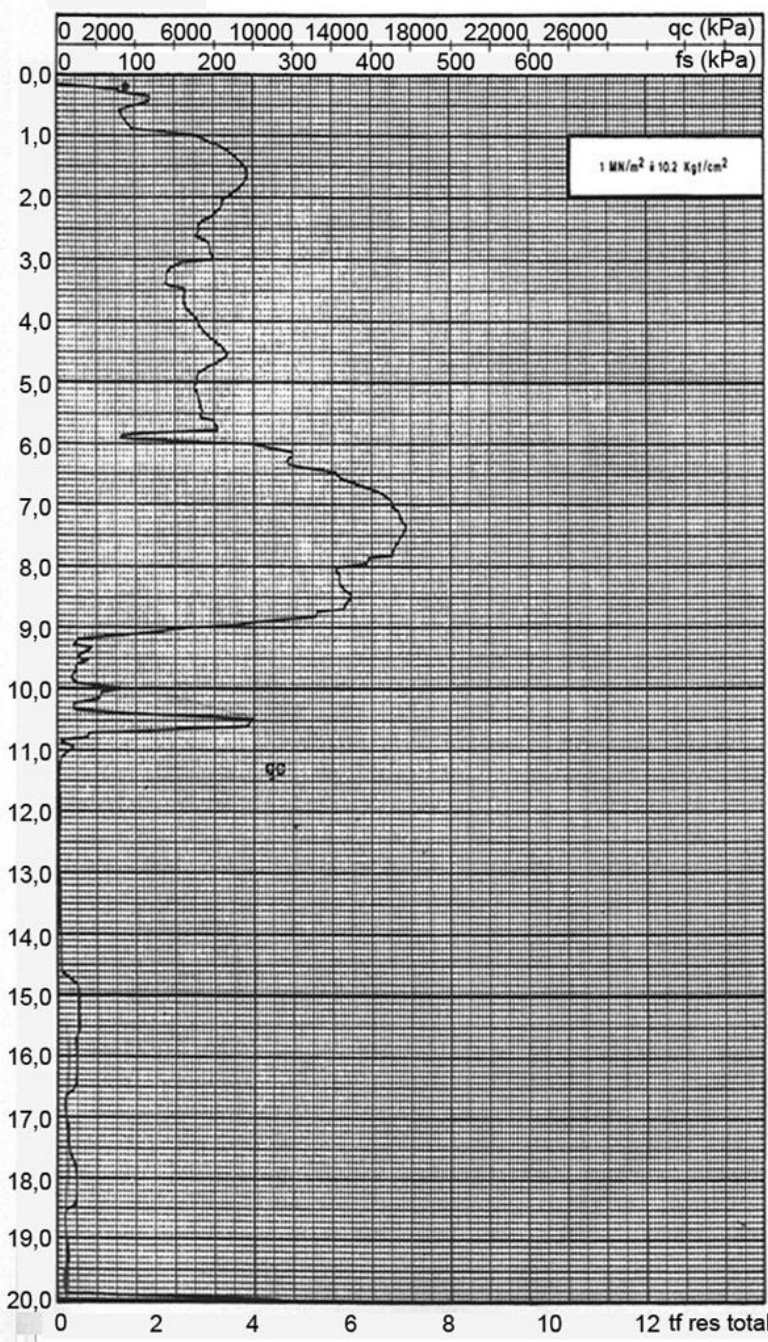

Figura 34 - Locação e resultados dos ensaios de CPT (Fonte: Cedido pela Zaclis Falconi, realizado pela PTS- Pesquisas Tecnológicas do solo (1997) 


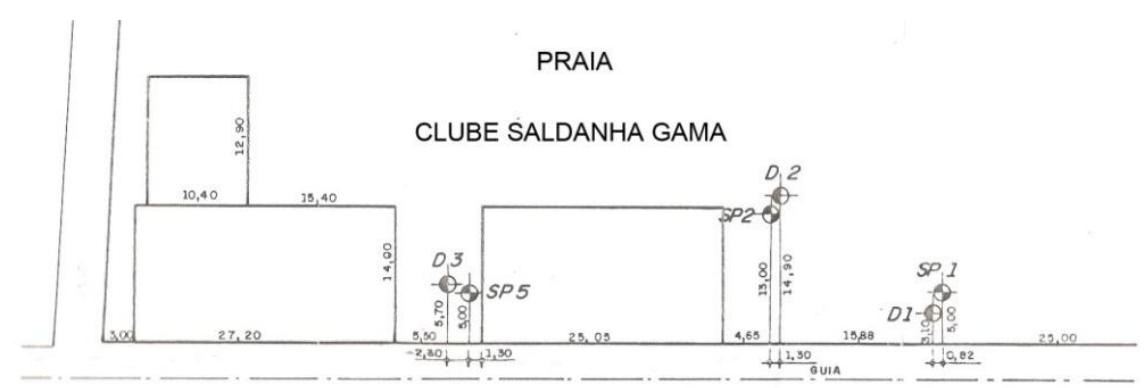

RUA REI ALBERTO

FIGURA (a)
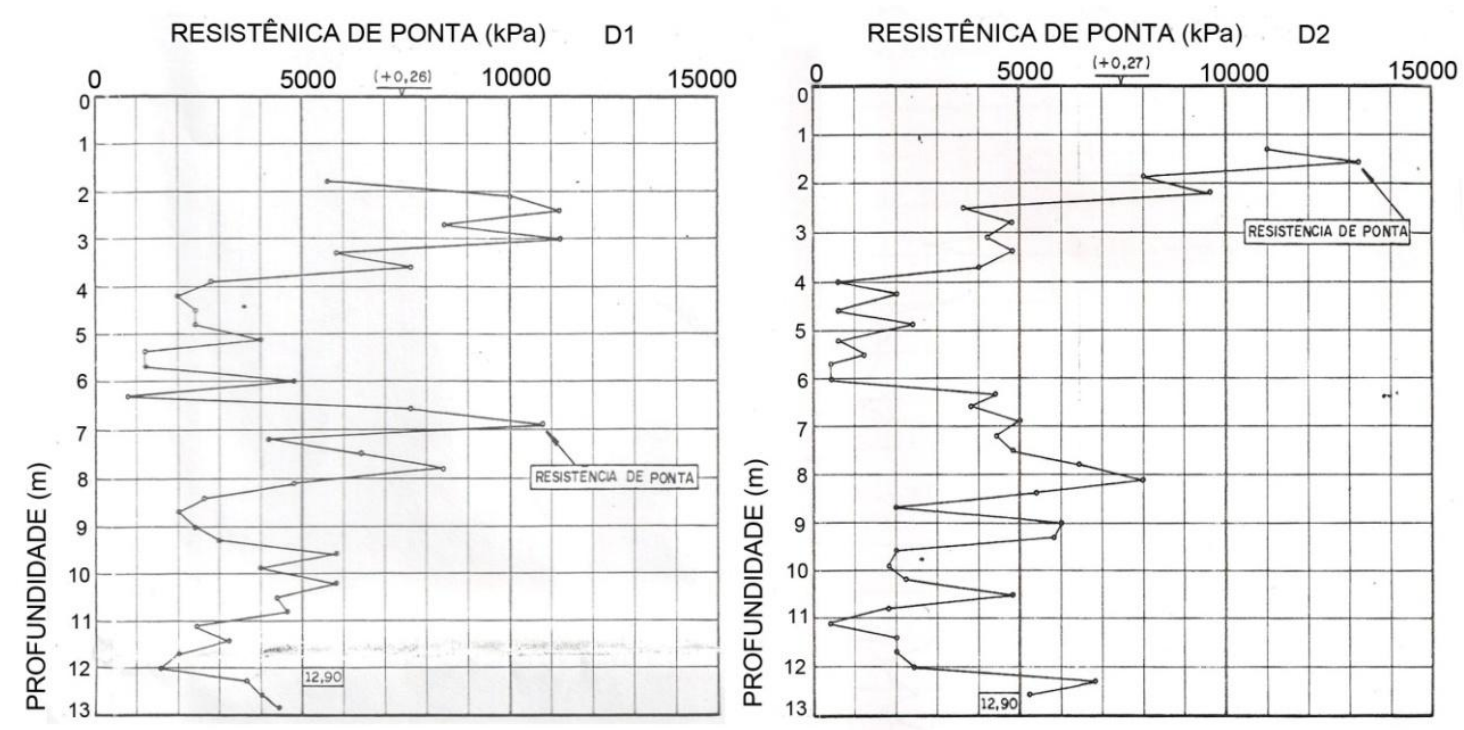

FIGURA (b)

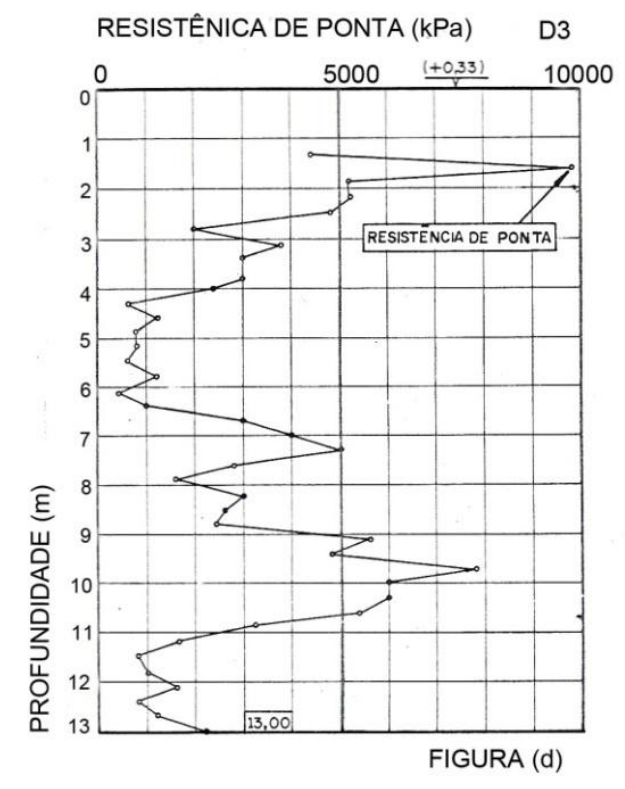

Figura 35 - Locação e resultados dos ensaios de CPT na Ponta da praia (Fonte: cedido pela Engensolos- Engenharia de Solos e Fundações (1978) 


\subsection{2 - Parâmetros geotécnicos obtidos através dos ensaios do cone}

No intuito de aprofundar os estudos, quanto às diferenças das propriedades geotécnicas da primeira camada de areia do bairro da Ponta da Praia e do bairro do Boqueirão, próximo à "Faixa Crítica", foram analisados somente os resultados dos CPT's na areia, mostrados nas figuras 34 e 35.

Para melhor compreensão dos dados, foram elaboradas as tabelas X, e XI que mostram os valores de $\mathrm{N}_{\mathrm{SPT}}$ e da resistência de ponta média, a cada da metro, para os dois ensaios de CPT, em seguida estão apresentados os gráficos (figuras 36 37), onde foram plotados os valores $\left(q_{c} \times N_{S P T}\right)$ e traçadas as curvas, para avaliar a variação da resistência de ponta com os valores de $\mathrm{N}_{\text {SPT }}$.

Tabela X - Resistência de Ponta média e valores de $\mathrm{N}_{S P T}$ médio ao longo da profundidade para os CPT's do bairro do Boqueirão (próximo à "Faixa Crítica")

\begin{tabular}{|c|c|c|c|}
\hline \multicolumn{4}{|c|}{ CPT-BOQUEIRÃO } \\
\hline & & CPT - I & CPT - II \\
\hline Prorunaidaae (m) & & Média qc (kPa) & Média qc (kPa) \\
\hline 1,0 & 9,5 & 3.500 & 2.250 \\
\hline 2,0 & 17 & 8.100 & 8.000 \\
\hline 3,0 & 14,5 & 7.100 & 7.750 \\
\hline 4,0 & 12,5 & 5.200 & 6.400 \\
\hline 5,0 & 14,5 & 7.000 & 8.000 \\
\hline 6,0 & 25 & 11.500 & 6.900 \\
\hline 7,0 & 22 & 16.000 & 14.000 \\
\hline 8,0 & 28 & 8.000 & 17.000 \\
\hline 9,0 & 2,5 & 13.500 & 12.750 \\
\hline 10,0 & 4 & 5.250 & 5.000 \\
\hline 11,0 & 3,0 & 4.000 & 5.250 \\
\hline
\end{tabular}




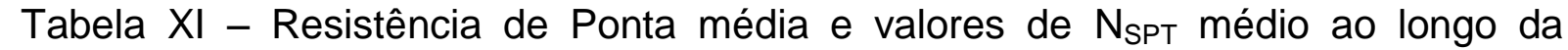
profundidade para o CPT's do bairro da Ponta da Praia

\begin{tabular}{|c|c|c|c|c|c|c|}
\hline \multicolumn{7}{|c|}{ CPT- PONTA DA PRAIA } \\
\hline \multirow{2}{*}{$\begin{array}{l}\text { Profundida } \\
\text { de }(\mathrm{m})\end{array}$} & \multirow{2}{*}{$\begin{array}{l}\text { NSPT } \\
\text { Sp01 }\end{array}$} & CPT - I & \multirow{2}{*}{$\begin{array}{l}\text { NSPT } \\
\text { Sp02 }\end{array}$} & CPT - II & \multirow{2}{*}{$\begin{array}{l}\text { NSPT } \\
\text { Sp05 }\end{array}$} & CPT-III \\
\hline & & $\begin{array}{c}\text { Média qc } \\
\qquad(\mathrm{kPa})\end{array}$ & & $\begin{array}{c}\text { Média qc } \\
(\mathrm{kPa})\end{array}$ & & $\begin{array}{c}\text { Média qc } \\
\qquad(\mathrm{kPa})\end{array}$ \\
\hline 1,0 & 19 & - & 15 & - & 16 & - \\
\hline 2,0 & 15 & 7.200 & 16 & 9.500 & 11 & 7.200 \\
\hline 3,0 & 13 & 10.100 & 21 & 7.500 & 10 & 3.550 \\
\hline 4,0 & 4 & 6.900 & 2 & 2.650 & 5 & 3.100 \\
\hline 5,0 & 3 & 2.500 & 2 & 1.400 & 5 & 1.250 \\
\hline 6,0 & 2 & 2.950 & 2 & 1.000 & 1 & 1.000 \\
\hline 7,0 & 9 & 5.800 & 7 & 2.750 & 7 & 2.250 \\
\hline 8,0 & 7 & 7.500 & 9 & 5.900 & 9 & 3.300 \\
\hline 9,0 & 3 & 3.500 & 2 & 5.000 & 10 & 3.500 \\
\hline 10,0 & 2 & 4.200 & 2 & 3.950 & 10 & 6.500 \\
\hline 11,0 & 3 & 4.900 & 3 & 2.900 & 9 & 4.250 \\
\hline 12,0 & 5 & 2.400 & 8 & 1.200 & 4 & 1.650 \\
\hline 13,5 & 5 & 3.300 & 5 & 3.500 & 110 & 1.600 \\
\hline
\end{tabular}




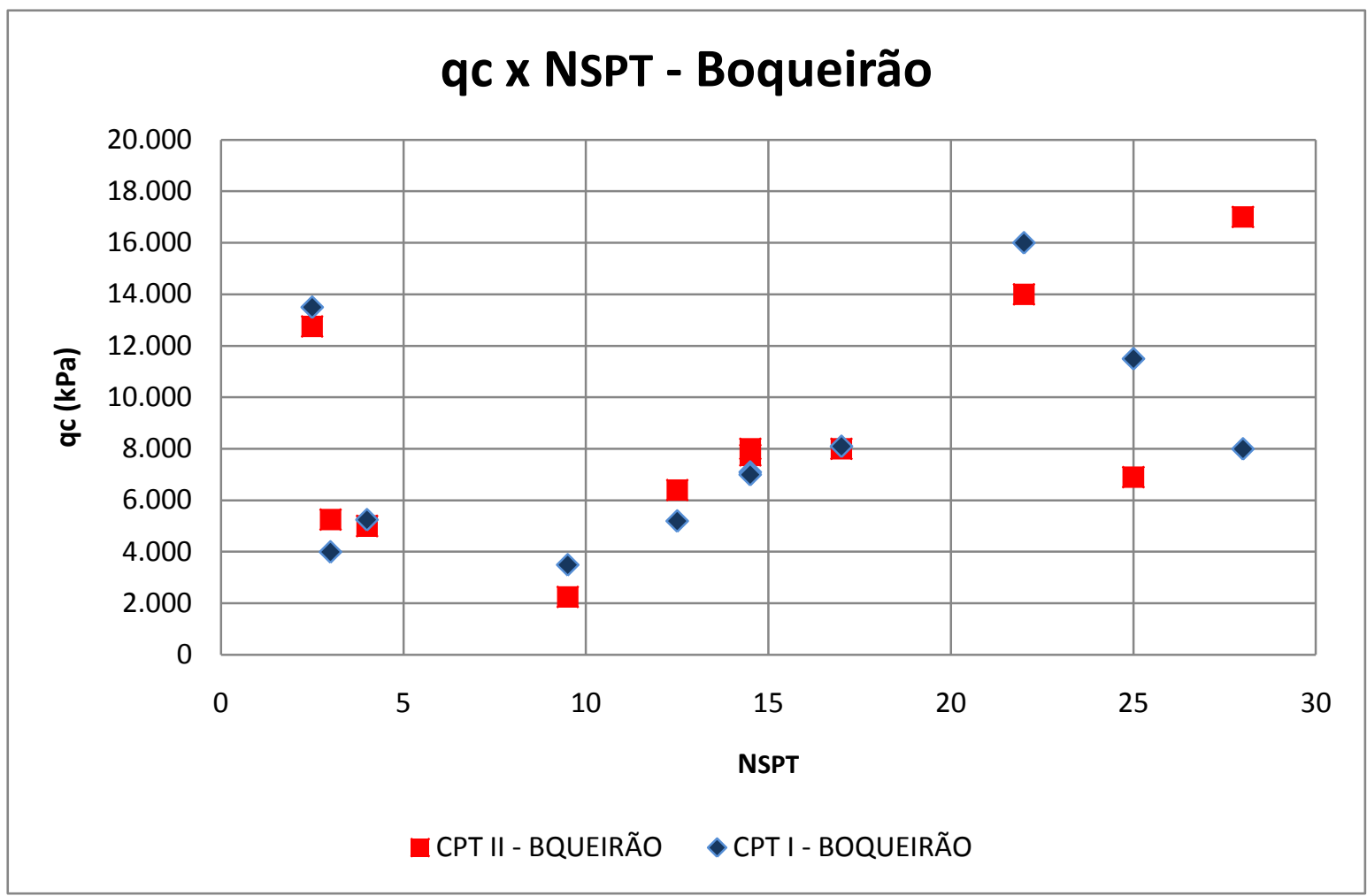

Figura 36 - Gráfico resistência de ponta média $\left(q_{c}\right) \times N_{S P T}$, para os CPTs do bairro do Boqueirão

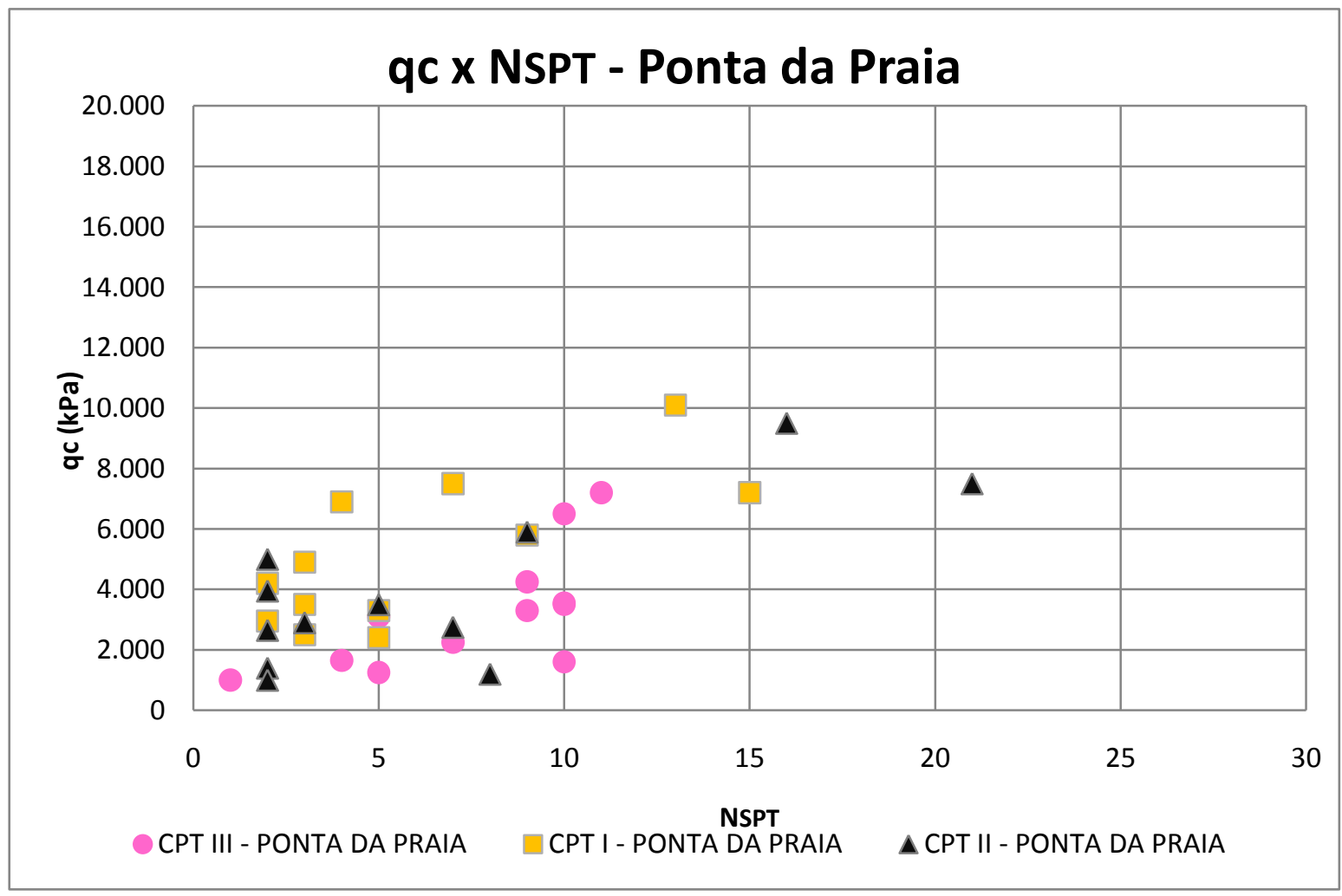

Figura 37 - Gráfico resistência de ponta média $\left(q_{c}\right) \times N_{S P T}$, para os CPTs da Ponta da Praia 


\subsubsection{1 - Densidade relativa e ângulo de atrito interno}

A medida de resistência de ponta de cone $q_{c}$ pode ser utilizada na previsão da densidade relativa $D_{r}$ ou do ângulo de atrito interno $\phi$, de acordo com Schnaid, 2000, o valor de $D_{r}$ pode ser obtido através da equação (I):

(I) $\mathrm{Dr}=-98+66 \log 10 \mathrm{qc} /\left(\sigma^{\prime} \mathrm{vo}\right) 0,5$

Sendo qc e $\sigma_{\text {vo }}$ expressos em $\mathrm{t} / \mathrm{m}^{2}$

Das tabelas X e XI tem-se $q_{c}$ médio (Boqueirão) $=8300 \mathrm{kPa}\left(830 \mathrm{t} / \mathrm{m}^{2}\right) ; q_{\mathrm{cmédio}}$ (Ponta da Praia $)=3800 \mathrm{kPa}\left(380 \mathrm{t} / \mathrm{m}^{2}\right)$. Admitindo $\gamma=1,8 \mathrm{t} / \mathrm{m}^{3}$ temos:

$\sigma_{\text {vo (boqueirão) }}^{\prime}=1,8 \times 1,25+(1,8-1,0) \times 9,75=10,0 \mathrm{t} / \mathrm{m}^{2}(100 \mathrm{kPa})$

$\sigma_{\text {vo }(\text { ponta da praia })}^{\prime}=1,8 \times 1,0+(1,8-1,0) \times 12=18,0 \mathrm{t} / \mathrm{m}^{2}(180(\mathrm{kPa})$

Aplicando a equação I, unidades em $\mathrm{tf} / \mathrm{m}^{2}$, tem-se:

$D_{r(\text { boqueirão })}=-98+66 \times \log _{10} \times\left(830 / 10^{0,5}\right)$

$D_{r(\text { boqueirão) }}=60 \%$

$D_{r}($ ponta da praia $)=-98+66 \times \log _{10} \times\left(380 / 18^{0,5}\right)$

$\mathrm{D}_{\mathrm{r}(\text { ponta da praia })}=30 \%$

A conversão de $D_{r}$ em ângulo de atrito pode ser realizada de acordo com a equação II, de Mello, 1971 apud Schnaid, 2000:

(II) $\quad\left(1,49-D_{\mathrm{r}}\right) \operatorname{tag} \phi=0,712$

Aplicando a equação II tem-se:

$(1,49-0,60) \operatorname{tag} \phi=0,712$

$\phi($ boqueirão $)=38^{0}$ 
$(1,49-0,30) \operatorname{tag} \phi=0,712$

$\phi_{(\text {ponta da praia })}=30^{\circ}$

\subsubsection{1 - Módulo de deformabilidade}

Ainda com os valores de resistência de ponta qc, é possível obter o valor do módulo de deformabilidade do solo (E), através de correlações. Segundo Schnaid (2000), existem restrições quanto a estimativa do módulo de deformabilidade, através de ensaios de penetração, pois, o módulo é função da história de tensões e deformações, e o cone não é capaz de fornecer medidas precisas de deformabilidade.

No entanto, na ausência de correlações desenvolvidas e validada para solos arenosos brasileiros, recomenda-se utilizar a expressão III, de Baldi, 1981 apud Schnaid, 2000, para a estimativa do módulo $E_{25}$ (para $25 \%$ da tensão desviadora máxima) onde:

(III) $\quad E_{25}=1,5 q_{c} ;$ sendo $q_{c}$ em $\mathrm{kPa}$

Portanto para os valores médios de $q_{c}$ da região em estudo tem-se:

$\mathrm{E}_{25(\text { boqueirão })}=1,5 \times 8300=12450 \mathrm{kPa}$

$E_{25(\text { ponta da praia })}=1,5 \times 3800=4750 \mathrm{kPa}$

A tabela XII abaixo é um resumo dos parâmetros obtidos para a primeira camada de areia do bairro da Ponta da Praia e Boqueirão, destacando os valores máximo, médio e mínimo encontrados na análise dos CPTs, com aplicação das equações (I), (II) e (III). 
Tabela XII - Parâmetros da primeira camada de areia dos bairros do Boqueirão e Ponta da Praia

\begin{tabular}{|c|c|c|c|c|c|c|c|c|c|c|}
\hline \multirow{5}{*}{ 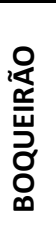 } & \multicolumn{2}{|c|}{ NSPT } & \multicolumn{2}{|c|}{$\mathrm{qc}(\mathrm{kPa})$} & \multicolumn{2}{|c|}{$\operatorname{Dr}(\%)$} & \multicolumn{2}{|c|}{$\phi$ (graus) } & \multicolumn{2}{|c|}{ E25 (kPa) } \\
\hline & $\max$ & $\min$ & $\max$ & $\min$ & $\max$ & $\min$ & $\max$ & $\min$ & $\max$ & $\min$ \\
\hline & 28 & 3 & 17000 & 2000 & 80 & 20 & 45 & 28 & 25500 & 3000 \\
\hline & \multirow{2}{*}{\multicolumn{2}{|c|}{$\begin{array}{c}\text { medio } \\
14\end{array}$}} & \multirow{2}{*}{\multicolumn{2}{|c|}{$\begin{array}{c}\text { medio } \\
8300\end{array}$}} & \multirow{2}{*}{\multicolumn{2}{|c|}{$\begin{array}{c}\text { medio } \\
60\end{array}$}} & \multirow{2}{*}{\multicolumn{2}{|c|}{$\begin{array}{c}\text { medio } \\
38\end{array}$}} & \multirow{2}{*}{\multicolumn{2}{|c|}{$\begin{array}{l}\text { medio } \\
12450\end{array}$}} \\
\hline & & & & & & & & & & \\
\hline \multirow{5}{*}{ 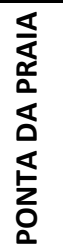 } & \multicolumn{2}{|c|}{ NSPT } & \multicolumn{2}{|c|}{$\mathrm{qc}(\mathrm{kPa})$} & \multicolumn{2}{|c|}{$\operatorname{Dr}(\%)$} & \multicolumn{2}{|c|}{$\phi$ (graus) } & \multicolumn{2}{|c|}{ E25 $(\mathrm{kPa})$} \\
\hline & $\max$ & $\min$ & $\max$ & $\min$ & $\max$ & $\min$ & $\max$ & $\min$ & $\max$ & $\min$ \\
\hline & 21 & 1 & 10100 & 1000 & 58 & - & 38 & & 15150 & 1500 \\
\hline & \multicolumn{2}{|c|}{ medio } & \multicolumn{2}{|c|}{ medio } & \multicolumn{2}{|c|}{ medio } & \multicolumn{2}{|c|}{ medio } & \multicolumn{2}{|c|}{ medio } \\
\hline & \multicolumn{2}{|c|}{8} & \multicolumn{2}{|c|}{3800} & \multicolumn{2}{|c|}{30} & \multicolumn{2}{|c|}{30} & \multicolumn{2}{|c|}{4750} \\
\hline
\end{tabular}

$\mathrm{Na}$ ausência de ensaios do cone, alguns autores como Aoki e Velloso (1975), Velloso (1991) e Sanglerat (1972), propuseram correlações entre o NSPT e o valor de $\mathrm{q}_{\mathrm{c}}$ de acordo com a expressão (IV) e gráfico IV respectivamente:

(IV) $\mathrm{q}_{\mathrm{c}}=\mathrm{KN}$, onde $\mathrm{N}$ é o valor do $\mathrm{N}_{\mathrm{SPT}}$

Os valores de K propostos por Aoki e Velloso (1975) estão apresentados na tabela XII

Tabela XII - valores de K propostos por Aoki e Velloso (1975)

\begin{tabular}{|c|c|}
\hline TIPO DE SOLO & $\mathrm{K}(\mathrm{kPa})$ \\
\hline Areia & 1000 \\
\hline Areia siltosa & 800 \\
\hline Areia silto-argilosa & 700 \\
\hline Areia argilosa & 600 \\
\hline Areia argilo-siltosa & 500 \\
\hline Argila & 200 \\
\hline Argila arenosa & 350 \\
\hline Argila areno-siltosa & 300 \\
\hline Argila siltosa & 220 \\
\hline
\end{tabular}

Tomando como exemplo os resultados dos CPTs I, II e III realizados no bairro da Ponta da Praia, aplicou-se a expressão (IV) e o gráfico da figura 38, para as 
profundidades de 2,0 e 12,0m, os resultados obtidos estão apresentados na tabela XII.

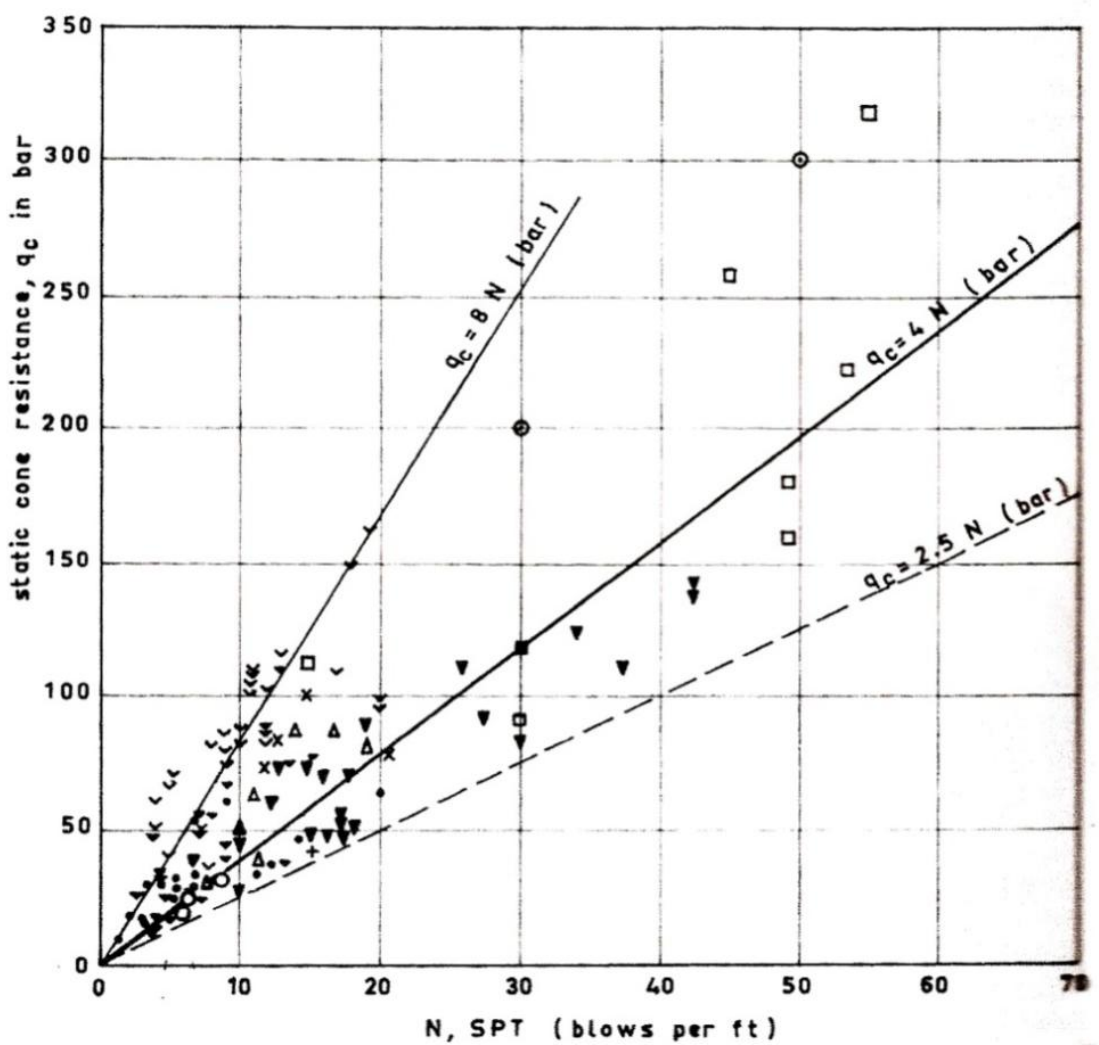

Figura 38 - Comparação entre qc e NSPT Sanglerat, 1972

Legenda:

$\begin{array}{ll}\mathrm{N}=6 \text { para argila arenosa } & \mathrm{N}=4 \text { para areia argilosa } \\ \mathrm{N}=5 \text { para silte arenoso } & \mathrm{N}=3 \text { para silte argiloso }\end{array}$

\subsection{3 - Análise dos resultados}

Foi observado que a resistência de ponta média ( $q_{c}$ médio $)$ no bairro da Ponta da Praia é igual a $3800 \mathrm{kPa}$ e no bairro do Boqueirão esse valor é mais que o dobro, igual a $8300 \mathrm{kPa}$. Além da resistência de ponta, valores de $\mathrm{N}_{\mathrm{SPT}}$, densidade relativa (Dr), ângulo de atrito interno $(\phi)$ e módulo de deformabilidade $(E)$, mostraram que, a primeira camada de areia do bairro da ponta da praia é menos resistente e mais fofa do que a primeira camada de areia do Boqueirão (próximo a "Faixa Crítica"), sendo elas diferentes não só quanto a espessura das camadas, mas também quanto as propriedades geotécnicas. 
Analisando os perfis geotécnicos e os gráficos de $q_{c}$ obtidos nos ensaios realizados na Ponta da Praia, notou-se a presença de uma camada de areia muito argilosa, próxima a superfície, por volta dos 4,0m de profundidade. Os CPTs se mostraram sensíveis a ela, apresentando uma queda na resistência de ponta ao atingi - la, já valores de $\mathrm{N}_{\mathrm{SPT}}$ não representaram quedas significativas ao atravessa -la

Os gráfico $q_{c} \times N_{S P T}$, conforme esperado, apresentaram valores dispersos. As

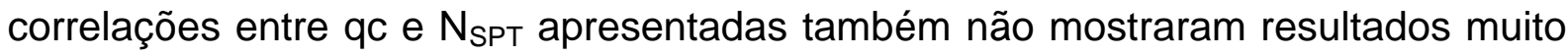
seguros. De acordo com Schnaid (2000), valores de qc calculados a partir de medidas de $\mathrm{N}_{\text {SPT }}$ (ou vice-versa) são imprecisos; isso pode ser devido a efeitos de energia de cravação, poro-pressão, entre outros, que não são considerados na medida do $\mathrm{N}_{\text {SPT. }}$. Portanto para execução de projetos, deve-se sempre adotar medidas diretas de ensaio.

Quanto à primeira camada de argila (SFL), verificou-se através dos Ensaios do Cone (CPT e CPTU) que a resistência de ponta, conforme esperado, apresentou valores bem baixos, em torno de 500 a $1200 \mathrm{kPa}$. A tabela XIII apresenta uma comparação entre o métodos tomando como exemplo resultados obtidos no CPT da Ponta da Praia para duas profundidades $(2,0$ e $12,0 \mathrm{~m})$.

Tabela XIII - Comparação entre os valores de campo, método de Aoki Velloso e Sanglerat para a Ponta da Praia

\begin{tabular}{|c|c|c|c|c|c|c|c|}
\hline Método & Prof.(m) & $N_{S P T}$ & $q_{c}(k P a)$ & $N_{S P T}$ & $q_{c}(k P a)$ & $N_{S P T}$ & $q_{c}(k P a)$ \\
\hline \multirow{2}{*}{$\begin{array}{l}\text { Ensaios de } \\
\text { campo }\end{array}$} & 2,0 & 15 & 7.200 & 16 & 9.500 & 11 & 7.200 \\
\hline & 12,0 & 5 & 2.400 & 8 & 1.200 & 4 & 1.650 \\
\hline \multirow{2}{*}{$\begin{array}{c}\text { Aoki Velloso- } \\
\text { para } \mathrm{K}=600 \mathrm{kPa}\end{array}$} & 2,0 & 15 & 8.400 & 16 & 9.600 & 11 & 6.600 \\
\hline & 12,0 & 5 & 3.000 & 8 & 4.800 & 4 & 2.400 \\
\hline \multirow{2}{*}{$\begin{array}{c}\text { Sanglerat } p / q_{c}= \\
4 N\end{array}$} & 2,0 & 15 & 5.800 & 16 & 6.200 & 11 & 5.500 \\
\hline & 12,0 & 5 & 2.000 & 8 & 2.600 & 4 & 1.500 \\
\hline
\end{tabular}




\section{4 - PREVISÃO DE RECALQUES}

\subsection{1 - Cálculos para a região da "Faixa Crítica" e Ponta da Praia; edifício com 16 pavimentos (edifício "A")}

No decorrer do presente trabalho, foram apresentadas diferenças entre o subsolo do Bairro da Ponta da Praia e da "Faixa Crítica", destacando um aumento significativo da espessura da primeira cama da de areia no bairro da Ponta da Praia. Com intuito de verificar a influência dessa camada na previsão de recalques, foi feita uma comparação entre os valores de recalques previstos para a região de estudo, supondo o mesmo edifício, apoiado em fundação direta, ora implementado na "Faixa Crítica", ora na Ponta da praia.

Para os cálculos, foi adotado um perfil genérico da "Faixa Critica" e um da Ponta da Praia. Admitiu-se a espessura média da primeira camada de areia da "Faixa Crítica" de 10,0m e da Ponta da Praia de 20,0m. Para a camada de argila SFL, adotou-se a mesma espessura de $20 \mathrm{~m}$ e as mesmas propriedades geotécnicas para as duas regiões. As figuras 39 e 40 mostram os perfis adotados.

Foi escolhido um edifício "A", hipotético, com 16 pavimentos, dimensões em planta $15 \mathrm{~m} \times 20 \mathrm{~m}$, carga total $=6.600 \mathrm{tf}$, Apoiado em radier a $1,5 \mathrm{~m}$ de profundidade. Foram admitidas duas situações para o sobreadensamento das argilas SFI:

1) Devido a oscilações do nível do mar (cerca de 2,0m abaixo do nível do mar atual; Massad, 1985);

2) Devido à ação de dunas no passado (adotada duna $=4,0 \mathrm{~m}$ de altura; $\gamma=$ $20 \mathrm{kPa})$.

Para o cálculo dos recalques por Adensamento, foi utilizado o método de Terzaghi que prevê para solos sobreadensados, a seguinte expressão:

$$
p=\frac{H}{1+e 0} x\left(C r \times \log \frac{\sigma^{\prime} a}{\sigma^{\prime} i}+C c x \log \frac{\sigma^{\prime} f}{\sigma^{\prime} a}\right)
$$


Onde:

$\mathrm{H}=$ espessura da camada de argila

Cc = índice de compressão

$\mathrm{e}_{0}=$ índice de vazios

$\sigma_{\mathrm{vi}}^{\prime}=$ tensão vertical efetiva inicial

$\sigma_{\mathrm{a}}^{\prime}=$ tensão pré-adensamento

$\sigma_{v f}^{\prime}=$ tensão vertical efetiva final

De acordo com Massad (2003), para as argilas de SFL da Baixada Santista, pode-se adotar como valor médio para $\frac{C c}{1+e 0}=0,43$ e para $\frac{C r}{1+e 0}=0,043$

Admitindo a dissipação de cargas do edifício adotado, conforme representação da figura 39, na metade da camada de argila (conforme teoria do adensamento), para a "Faixa Crítica", tem-se a tensão distribuída atuante $(q)=108 \mathrm{kPa}$. Efetuando os cálculos para a 1 hipótese de sobreadensamento (elevação negativa do nível do mar). Para a faixa crítica tem-se:

$\sigma_{\mathrm{vi}}^{\prime}=(18 \times 1,5)+(18-10) \times 8,5+(16-10) \times 10=155 \mathrm{kPa}$

$\sigma_{\mathrm{vf}}^{\prime}=(18 \times 1,5)+(18-10) \times 8,5+(16-10) \times 10+108=263 \mathrm{kPa}$

$\sigma_{\mathrm{a}}^{\prime}=(18 \times 1,5)+(18-10) \times 8,5+(16-10) \times 10+20=175$

$\rho=0,043 \times 20 \times \log (175 / 155)+0,43 \times 20 \times \log (263 / 175)$

$\rho_{\text {primário }}=156 \mathrm{~cm}$

Ainda para a "faixa crítica, será admitido a segunda hipótese de sobreadensamento (ação de dunas), sendo altura da duna adotada $=4,0 \mathrm{~m}$, aplicando a teoria do Adensamento tem-se

$$
\begin{aligned}
& \sigma_{\mathrm{vi}}^{\prime}=(18 \times 1,5)+(18-10) \times 8,5+(16-10) \times 10=155 \mathrm{kPa} \\
& \sigma_{\mathrm{vf}}^{\prime}=(18 \times 1,5)+(18-10) \times 8,5+(16-10) \times 10+108=263 \mathrm{kPa} \\
& \sigma_{\mathrm{a}}^{\prime}=(18 \times 1,5)+(18-10) \times 8,5+(16-10) \times 10+(20 \times 4)=235 \mathrm{kPa} \\
& \rho=0,043 \times 20 \times \log (235 / 155)+0,43 \times 20 \times \log (263 / 235) \\
& \rho_{\text {primário }}=57 \mathrm{~cm}
\end{aligned}
$$


Admitindo a dissipação de cargas do edifício adotado, conforme representação da figura 40, na metade da camada de argila, de para a Ponta da Praia, tem-se a carga distribuída atuante $(\mathrm{q})=77 \mathrm{kPa}$. Efetuando os cálculos para a 1 hipótese de sobreadensamento (elevação negativa do nível do mar) tem-se:

$\sigma_{\mathrm{vi}}^{\prime}=(18 \times 1,5)+(18-10) \times 18,5+(16-10) \times 10=235 \mathrm{kPa}$

$\sigma_{v f}^{\prime}=(18 \times 1,5)+(18-10) \times 18,5+(16-10) \times 10+77=312 \mathrm{kPa}$

$\sigma_{a}^{\prime}=(18 \times 1,5)+(18-10) \times 18,5+(16-10) \times 10+20=255 \mathrm{kPa}$

$\rho=0,043 \times 20 \times \log (255 / 235)+0,43 \times 20 \times \log (312 / 255)$

$\rho=78 \mathrm{~cm}$

Ainda para a Ponta da Praia, admitindo a segunda hipótese de sobreadensamento (ação de dunas), com $\mathrm{h}=4,0 \mathrm{~m}$, tem-se:

$\sigma_{\mathrm{vi}}^{\prime}=(18 \times 1,5)+(18-10) \times 18,5+(16-10) \times 10=235 \mathrm{kPa}$

$\sigma_{\mathrm{vf}}^{\prime}=(18 \times 1,5)+(18-10) \times 18,5+(16-10) \times 10+77=312 \mathrm{kPa}$

$\sigma_{a}^{\prime}=(18 \times 1,5)+(18-10) \times 18,5+(16-10) \times 10+(4 \times 20)=315 \mathrm{kPa}$

$\rho=0,043 \times 20 \times \log (315 / 235)$

$\rho=10 \mathrm{~cm}$ 


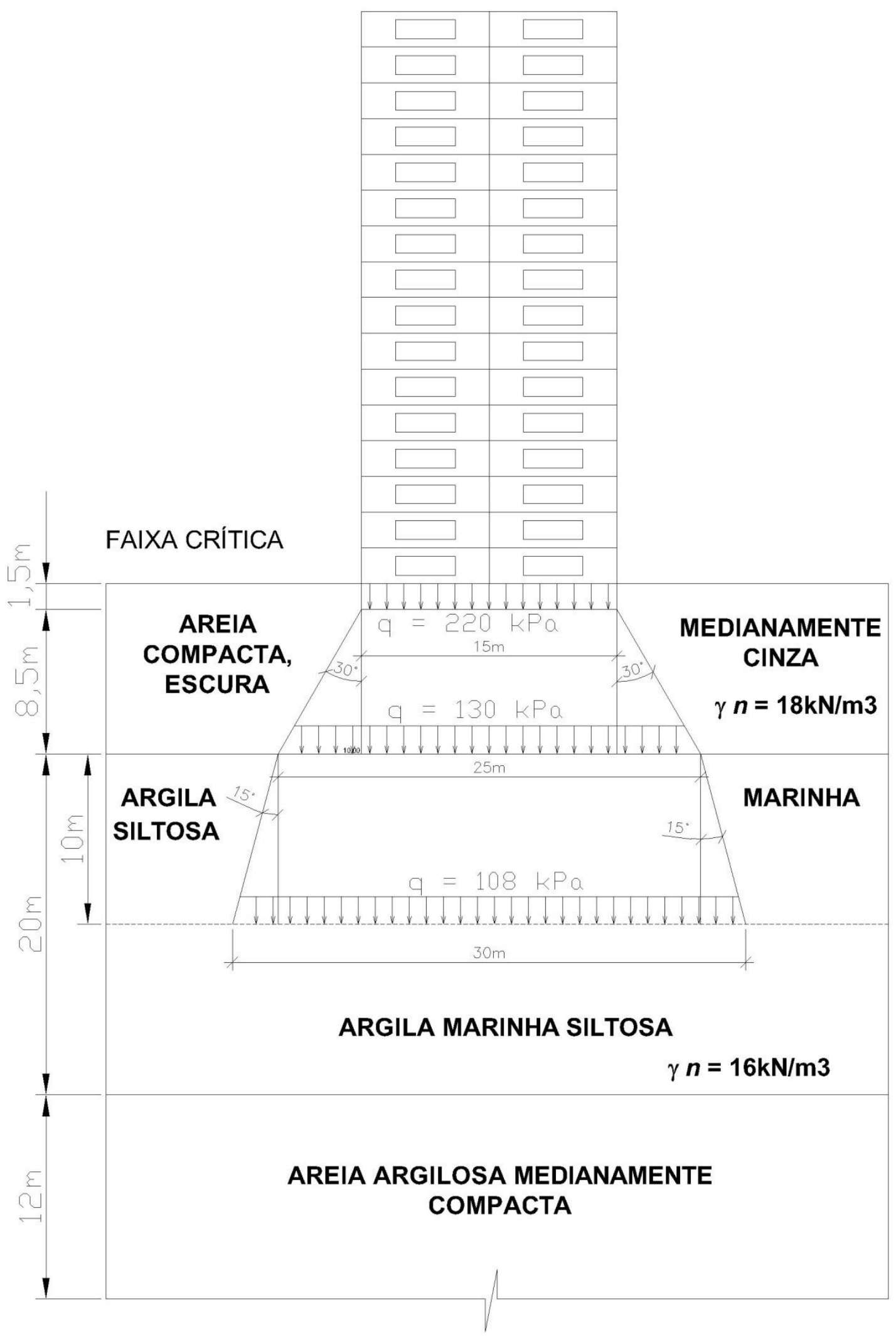

Figura 39 - Esquema de dissipação de cargas para o perfil adotado da "Faixa Crítica" edifíco "A", com 16 pavimentos 


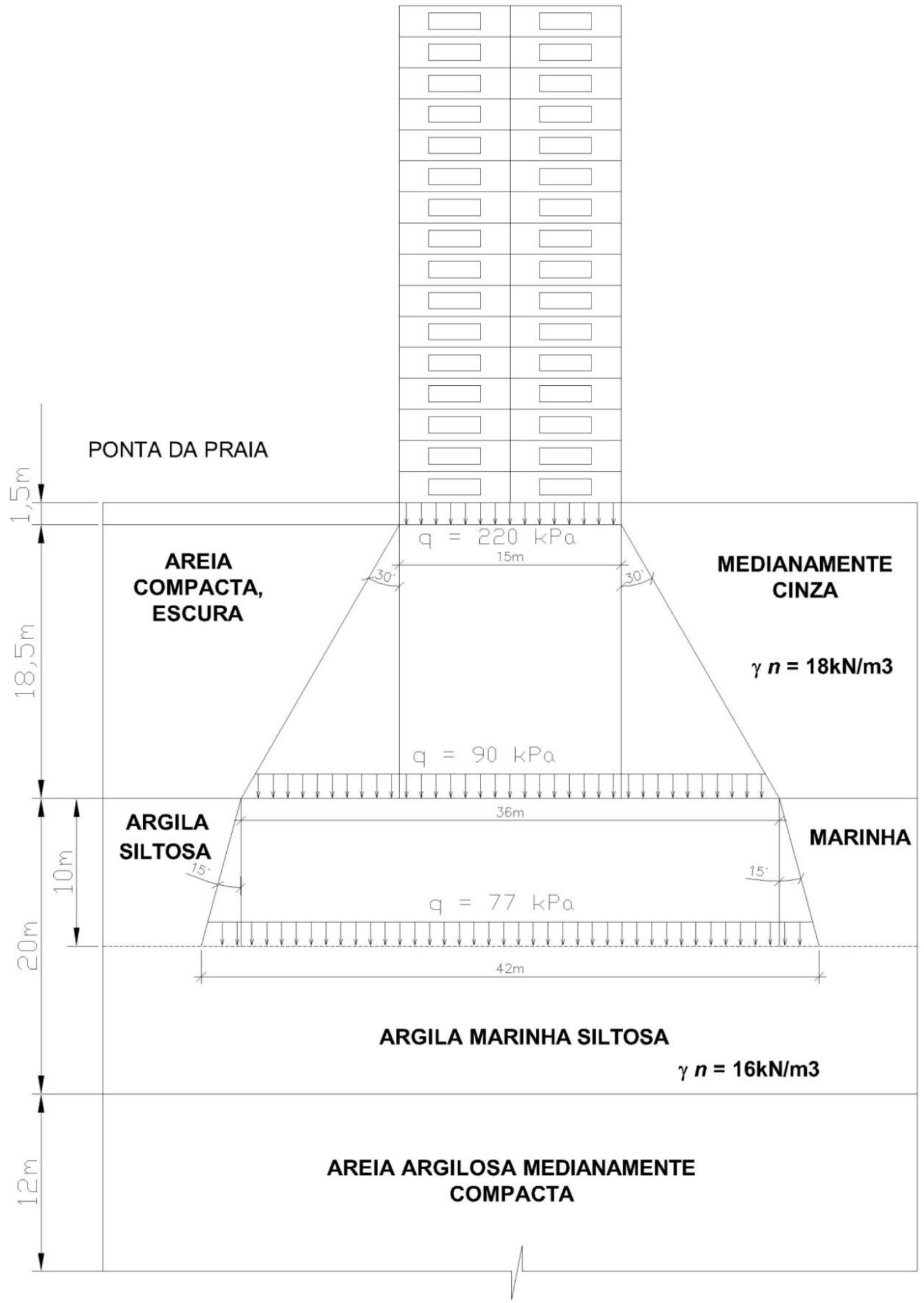

Figura 40 - Esquema de dissipação de cargas para o perfil adotado da Ponta da Praia edifício "A", com 16 pavimentos 


\subsection{2 - Cálculos para a região da "Faixa Crítica" e Ponta da Praia - edifício com 12 pavimentos (edifício “ $B$ ”)}

Como segunda análise, propôs-se um edifico "B", também hipotético, com 12 pavimentos, dimensões em planta iguais as do edifício "A". Por se tratar de um edifício especial, que comportará depósitos de carga pesada, seu peso equivale a um edifício de 14 pavimentos. Carga total $=5.000 t f$, também apoiado em radier a $1,5 \mathrm{~m}$ de profundidade, sobre o perfil geotécnico representado nas figuras 41 e 42 . Para os cálculos, foram mantidas as duas situações de sobreadensamento das argilas SFI:

Devido as elevações do nível do mar (+/-2,0m acima do nível do mar atual; Massad, 1985);

Devido a ação de dunas no passado (adotada duna $=4,0 \mathrm{~m}$ de altura; $\gamma=20 \mathrm{kPa}$ ).

De acordo com a dissipação de cargas do edifício "B", representada na figura 41, na metade da camada de argila, para a "Faixa Crítica", tem-se a carga distribuída atuante $(q)=82,5 \mathrm{kPa}$. Efetuando os cálculos para a 1 hipótese de sobreadensamento (elevação negativa do nível do mar) tem-se:

$\sigma_{\mathrm{vi}}^{\prime}=(18 \times 1,5)+(18-10) \times 8,5+(16-10) \times 10=155 \mathrm{kPa}$

$\sigma_{\mathrm{vf}}^{\prime}=(18 \times 1,5)+(18-10) \times 8,5+(16-10) \times 10+82,5=237,5 \mathrm{kPa}$

$\sigma_{a}^{\prime}=(18 \times 1,5)+(18-10) \times 8,5+(16-10) \times 10+20=175$

$\rho=0,043 \times 20 \times \log (175 / 155)+0,43 \times 20 \times \log (237,5 / 175)$

Pprimário $=118 \mathrm{~cm}$

Ainda para a "Faixa Crítica, admitido a segunda hipótese de sobreadensamento temse:

$$
\begin{aligned}
& \sigma_{\mathrm{vi}}^{\prime}=(18 \times 1,5)+(18-10) \times 8,5+(16-10) \times 10=155 \mathrm{kPa} \\
& \sigma_{\mathrm{vf}}^{\prime}=(18 \times 1,5)+(18-10) \times 8,5+(16-10) \times 10+82,5=237,5 \mathrm{kPa} \\
& \sigma_{\mathrm{a}}^{\prime}=(18 \times 1,5)+(18-10) \times 8,5+(16-10) \times 10+(20 \times 4)=235 \mathrm{kPa} \\
& \rho=0,043 \times 20 \times \log (235 / 155)+0,43 \times 20 \times \log (237,5 / 235) \\
& \rho_{\text {primário }}=19 \mathrm{~cm}
\end{aligned}
$$


Admitindo a dissipação de cargas do edifício "B" adotado, conforme representação da figura 42, na metade da camada de argila, de para a Ponta da Praia, tem-se a carga distribuída atuante $(q)=58,5 \mathrm{kPa}$. Efetuando os cálculos para a 1 hipótese de sobreadensamento (elevação negativa do nível do mar) tem-se:

$\sigma_{v i}^{\prime}=(18 \times 1,5)+(18-10) \times 18,5+(16-10) \times 10=235 \mathrm{kPa}$

$\sigma_{\mathrm{vf}}^{\prime}=(18 \times 1,5)+(18-10) \times 18,5+(16-10) \times 10+58,5=293,5 \mathrm{kPa}$

$\sigma_{a}^{\prime}=(18 \times 1,5)+(18-10) \times 18,5+(16-10) \times 10+20=255 \mathrm{kPa}$

$\rho=0,043 \times 20 \times \log (255 / 235)+0,43 \times 20 \times \log (293,5 / 255)$

$\rho=55 \mathrm{~cm}$

Ainda para a Ponta da Praia, admitindo a segunda hipótese de sobreadensamento tem-se:

$$
\begin{aligned}
& \sigma_{v i}^{\prime}=(18 \times 1,5)+(18-10) \times 18,5+(16-10) \times 10=235 \mathrm{kPa} \\
& \sigma_{v f}^{\prime}=(18 \times 1,5)+(18-10) \times 18,5+(16-10) \times 10+58,5=294 \mathrm{kPa} \\
& \sigma_{a}^{\prime}=(18 \times 1,5)+(18-10) \times 18,5+(16-10) \times 10+(4 \times 20)=315 \mathrm{kPa} \\
& \rho=0,043 \times 20 \times \log (315 / 235) \\
& \rho=10 \mathrm{~cm}
\end{aligned}
$$




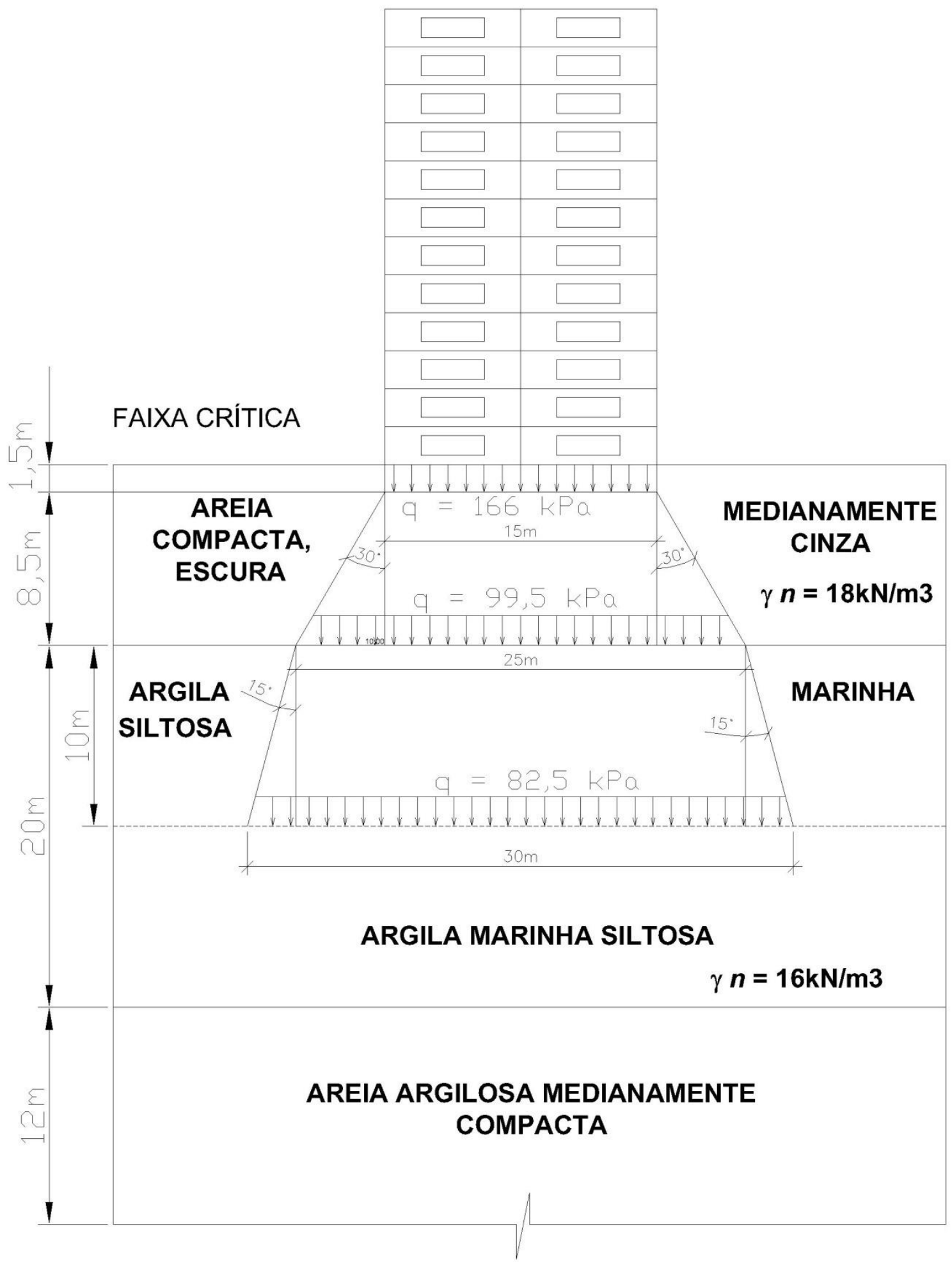

Figura 41 - Esquema de dissipação de cargas para o perfil adotado da "Faixa Crítica" edifício "B", com 12 pavimentos 


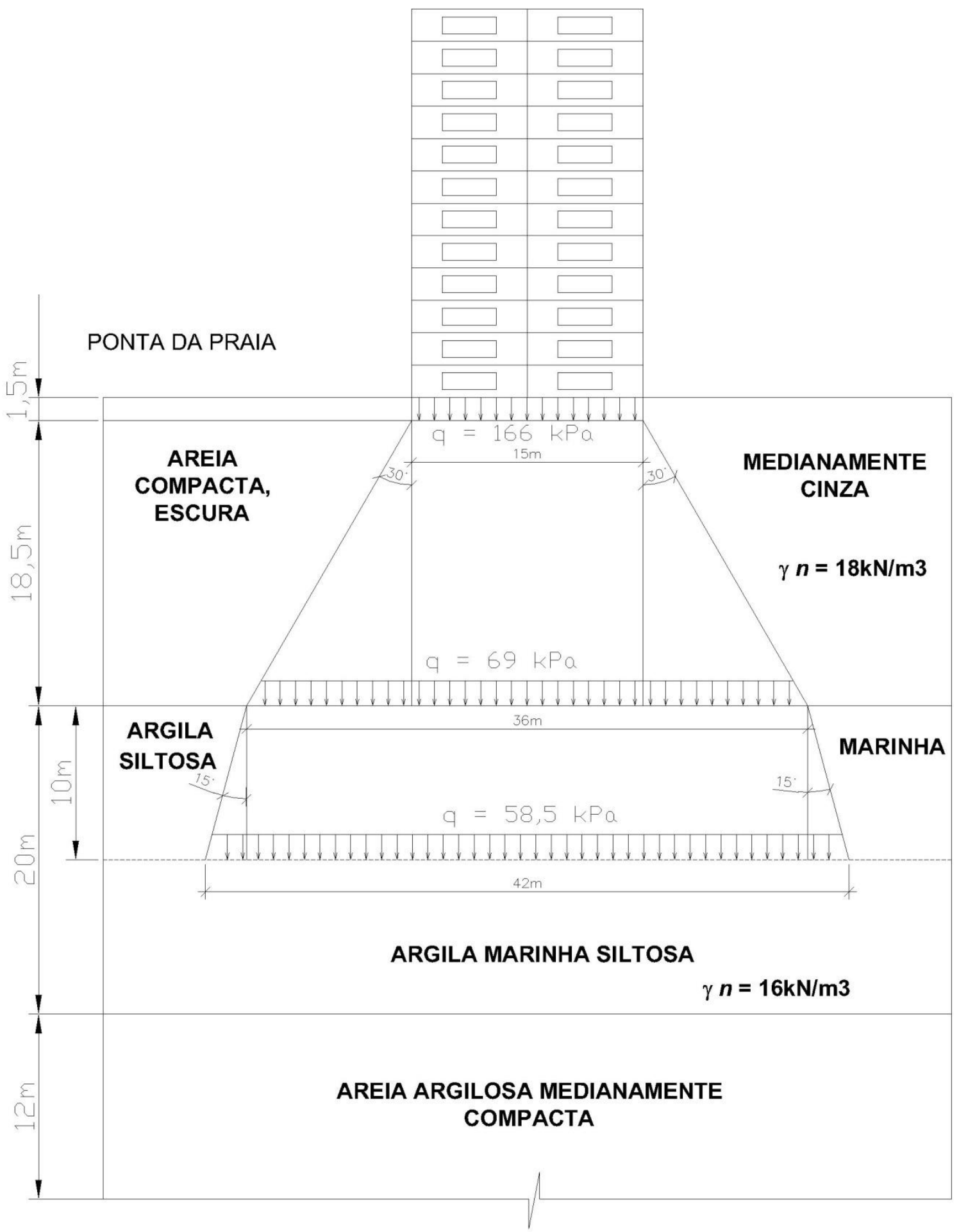

Figura 42 - Esquema de dissipação de cargas para o perfil adotado da Ponta da Praia edifício "B", com 12 pavimentos 


\subsection{3 - Resumos dos valores obtidos}

Tabela XIV - Resumo dos recalques obtidos para o bairro da Ponta da Praia e "Faixa Crítica"

\begin{tabular}{|c|c|c|c|c|c|c|c|c|c|}
\hline Edif. & REGIÃO & $\begin{array}{c}\text { Mecanismo de } \\
\text { Sobradensamento }\end{array}$ & $\begin{array}{c}\sigma^{\prime} i \\
(k P a)\end{array}$ & $\begin{array}{c}q \\
(k P a)\end{array}$ & $\begin{array}{c}\sigma^{\prime} f \\
(k P a)\end{array}$ & $\begin{array}{c}\sigma^{\prime} a \\
(k P a)\end{array}$ & $R S A$ & \begin{tabular}{|c|} 
primário \\
$(\mathrm{cm})$
\end{tabular} & $\begin{array}{c}\text { E primário } \\
(\%)\end{array}$ \\
\hline \multirow{4}{*}{ 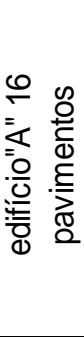 } & FAIXA & $\begin{array}{l}\text { oscilação negativa } \\
\text { do nível do mar }\end{array}$ & 155 & 108 & 263 & 175 & 1,12 & 157 & 7,9 \\
\hline & CRÍTICA & $\begin{array}{c}\text { ação } \\
\text { de dunas }\end{array}$ & 155 & 108 & 263 & 235 & 1,52 & 57 & 2,9 \\
\hline & PONTA DA & $\begin{array}{c}\text { oscilação negativa } \\
\text { do nível do mar }\end{array}$ & 235 & 77 & 312 & 255 & 1,09 & 78 & 3,9 \\
\hline & PRAIA & $\begin{array}{c}\text { ação } \\
\text { de dunas }\end{array}$ & 235 & 77 & 312 & 315 & 1,34 & 10 & 0,5 \\
\hline \multirow{4}{*}{ 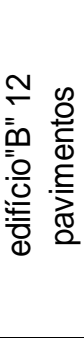 } & FAIXA & $\begin{array}{c}\text { oscilação negativa } \\
\text { do nível do mar }\end{array}$ & 155 & 82,5 & 237,5 & 175 & 1,12 & 118 & 5,9 \\
\hline & CRÍTICA & $\begin{array}{c}\text { ação } \\
\text { de dunas }\end{array}$ & 155 & 82,5 & 237,5 & 235 & 1,52 & 19 & 1 \\
\hline & PONTA DA & $\begin{array}{c}\text { oscilação negativa } \\
\text { do nível do mar }\end{array}$ & 235 & 58,5 & 294 & 255 & 1,09 & 55 & 2,8 \\
\hline & PRAIA & $\begin{array}{c}\text { ação } \\
\text { de dunas }\end{array}$ & 235 & 58,5 & 294 & 315 & 1,34 & 8 & 0,4 \\
\hline
\end{tabular}

Tabela XV - Relação dos recalques primários ( $\rho$ ), entre as regiões de estudo para o mesmo mecanismo de sobreadensamento

\begin{tabular}{|c|c|c|c|}
\hline Mecanismo de & \multirow[b]{2}{*}{ Região } & \multicolumn{2}{|c|}{$\rho$ primário $(\mathrm{cm})$} \\
\hline $\begin{array}{c}\text { de } \\
\text { Sobradensamento }\end{array}$ & & $\begin{array}{c}\text { Edifício } A \\
16 \text { pavimentos }\end{array}$ & $\begin{array}{c}\text { Edifício B } \\
12 \text { pavimentos }\end{array}$ \\
\hline oscilação & Faixa & \multirow[b]{2}{*}{157} & \multirow[b]{2}{*}{118} \\
\hline negativa & crítica & & \\
\hline do nível & Ponta da & \multirow[b]{2}{*}{78} & \multirow[b]{2}{*}{55} \\
\hline do mar & Praia & & \\
\hline \multicolumn{2}{|c|}{ Relação } & 2,0 & 2,0 \\
\hline & Faixa & \multirow[b]{2}{*}{57} & \multirow[b]{2}{*}{19} \\
\hline Ação & crítica & & \\
\hline \multirow[t]{2}{*}{ de dunas } & Ponta da & \multirow[b]{2}{*}{10} & \multirow[b]{2}{*}{8,0} \\
\hline & Praia & & \\
\hline \multicolumn{2}{|c|}{ Relação } & 5,7 & 2,4 \\
\hline
\end{tabular}


Tabela XVI - Relação dos recalques primáios $(\rho)$, entre os mecanismos de sobreadensamento para uma mesma região

\begin{tabular}{|c|c|c|c|}
\hline \multirow{2}{*}{ Região } & \multirow{2}{*}{ Região } & \multicolumn{2}{c|}{$\rho$ primário (cm) } \\
\cline { 3 - 4 } & & $\begin{array}{c}\text { Edifício A } \\
\text { 16 pavimentos }\end{array}$ & $\begin{array}{c}\text { Edifício B } \\
\text { 12 pavimentos }\end{array}$ \\
\hline \multirow{2}{*}{ Faixa crítica } & $\begin{array}{c}\text { oscilação negativa } \\
\text { do nível do mar }\end{array}$ & 157 & 118 \\
\cline { 2 - 4 } & Dunas & 57 & 19 \\
\hline \multicolumn{2}{|c|}{ Relação } & 2,7 & 6,2 \\
\hline Ponta da & $\begin{array}{c}\text { oscilação negativa } \\
\text { do nível do mar }\end{array}$ & 78 & 55 \\
\cline { 2 - 4 } & Dunas & 10 & 8 \\
\hline \multicolumn{2}{|c|}{ Relação } & 7,8 & 6,9 \\
\hline
\end{tabular}

\subsection{4 - Análise dos cálculos efetuados}

Com o espraiamento das cargas mostradas na figuras 39, 40,41 e 42, pode-se notar (tabela XIV) que, devido à maior espessura da primeira camada de areia do bairro da Ponta da Praia, o incremento de tensão (q) que atinge o plano médio da primeira camada de argila SFL é cerca de 1,4 vezes menor do que na "Faixa Crítica". Em relação à tensão de pré-adensamento, em média, a mesma relação se mantém, sendo neste caso, maior na Ponta da Praia. No entanto, as RSA são muito próximas, para o mesmo mecanismo de sobreadensamento.

Analisando os valores obtidos para as duas regiões em estudo e os mecanismos de sobreadensamento, foi possível tirar algumas conclusões, como seguem:

Os valores de recalques admitindo o sobreadensamento das argilas devido às oscilações negativas do nível do mar, tanto para o edifício de 16 pavimentos (A) quanto para o edifício de 12 pavimentos (B), na Ponta da Praia, foram cerca de duas vezes menores que os recalques encontrados na "Faixa Crítica". (ver tabela XV). Dessa forma entende-se que o aumento da espessura da primeira camada de areia no bairro da Ponta da Praia, reduziu pela metade, os valores dos recalques em comparação com a "Faixa Crítica". 
Nos cálculos admitindo o sobreadensamento das argilas devido à ação de dunas, verificou-se que para o edifício "A", na Ponta da Praia, o valor do recalque encontrado foi cerca de seis vezes menor que o da "Faixa Crítica" (ver tabela XV).

Para o edifício $B$, uma análise da tabela XIV revela que o incremento de tensão praticamente não atinge a reta virgem, tanto na Ponta da Praia, quanto na "faixa crítica". Daí a razão dos pequenos recalques indicados na tabela XV.

Verificou-se também que a ação de dunas no passado pode contribuir na diminuição dos recalques em cerca de seis vezes na "Faixa Crítica" e até oito vezes na Ponta da Praia (tabela XVI)

Em resumo os valores obtidos confirmam que na Ponta da Praia as tensões que chegam à camada de argila são menores que na "Faixa Crítica", diminuindo significativamente os valores dos recalques. Entende-se também que na Ponta da Praia a sobreposição dos bulbos de tensão entre prédios vizinhos, foi pequena, ou até mesmo inexistente, principalmente se admitirmos a espessa camada de areia em conjunto com a ação de dunas, dessa foram não há contribuição para recalques diferencias.

\section{5 - READAPTAÇÃO DA SEÇÃO GEOTÉCNICA DA ORLA DE SANTOS}

\subsection{1 - Destaque a orla do bairro da Ponta da Praia e seção transversal à praia.}

Com as análises realizadas, foi possível readaptar o perfil geotécnico de Teixeira (figura 43), esclarecendo a dúvida quanto à espessura da camada de areia na Ponta da Praia deixado por Massad (2003) e retraçar o perfil geotécnico da orla da ponta da praia, representado na figura 44.

No perfil da figura 43, foi inserido um novo questionamento quanto as camadas de argila SFL e AT no bairro da Ponta da Praia, pois, como mencionado anteriormente, à medida que se aproxima do Guarujá, essas camadas se confundem, não sendo possível afirmar a profundidade correta de sua ocorrência.

Mantém-se ainda a interrogação abaixo da camada de argila AT. Isto é devido a grande quantidade de sondagens analisadas na região da Ponta da Praia, não serem profundas: muitas delas não atravessaram por completo a camada de argila SFL. Outro fato são as argilas encontradas nas sondagens executadas 
recentemente, abaixo dos $60,0 \mathrm{~m}$ de profundidade, com características diferentes das ATs, e a dúvida quanto a profundidade do topo rochoso que foi encontrado abaixo dos $80 \mathrm{~m}$ de profundidade na "Faixa Crítica".

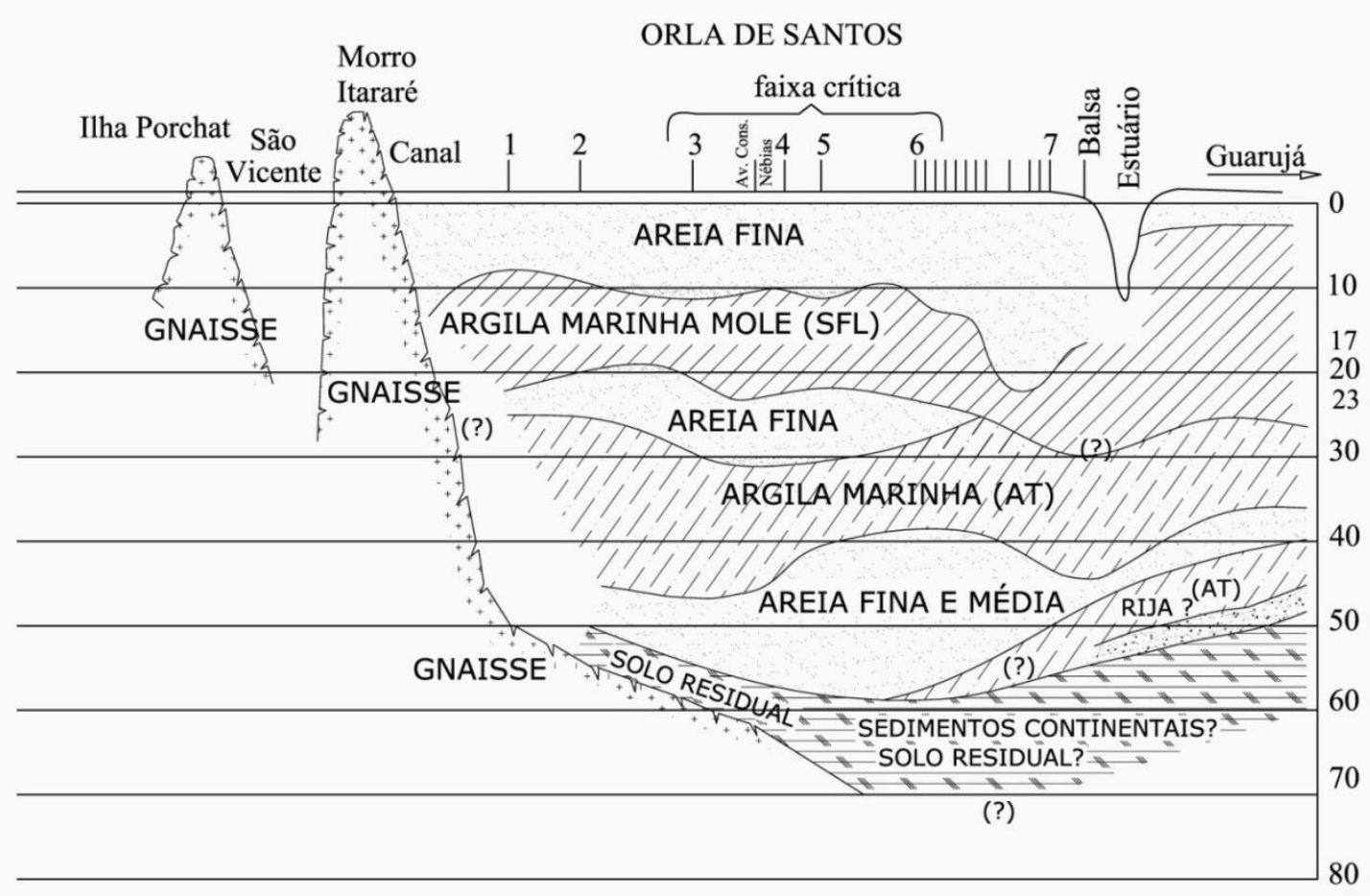

Figura 43 - Perfil Geotécnico sintético da orla praiana - Adaptado de Teixeira (1994) e Massad (2003). 

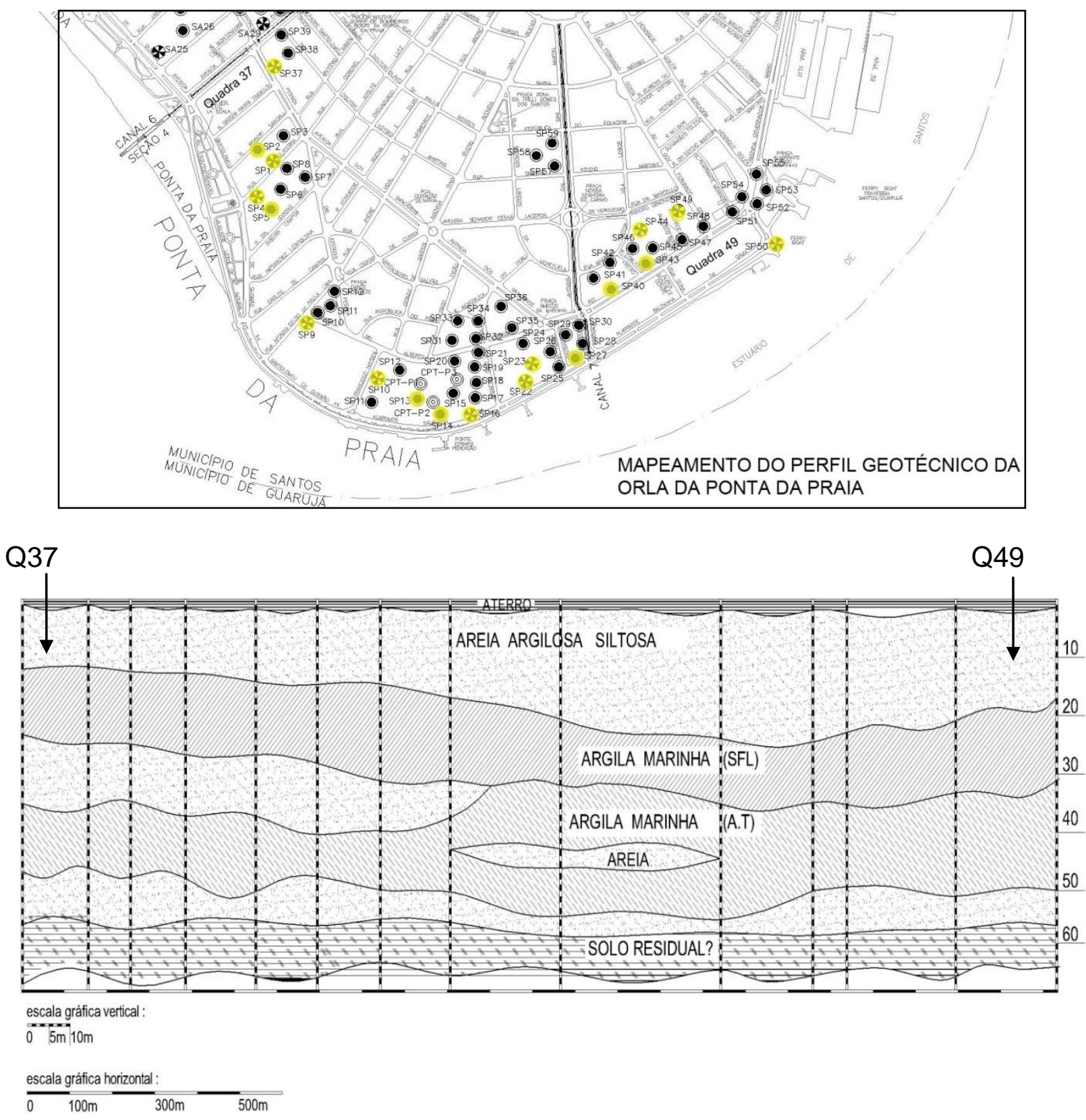

Figura 44 - Representação do perfil geotécnico sintético da orla da Ponta da Praia e mapeamento

\subsection{2 - Seções transversais a orla de Santos}

Conforme já relatado no presente trabalho, foram coletadas sondagens em diversos locais da cidade de Santos. Na tentativa de representar o subsolo Santista, decidiuse traçar seções transversais ao longo de alguns canais. 
As seções foram desenhadas da orla em direção ao centro, tendo como limite a linha do trem, que passa no sentido longitudinal à cidade. As seções traçadas são bem genéricas, havendo uma distância bem grande entre uma sondagem e outra. Além disso, as sondagens foram projetadas em direção aos canais, para traçar os perfis em um mesmo sentido, praia - centro.

Também foi preciso "extrapolar" algumas sondagens pois,como algumas são curtas, elas foram prolongadas de acordo com a sondagem mais próxima, para compor os perfis. Em trabalhos futuros, modificações e correções deverão ser feitas, à medida que novas sondagens puderem ser incorporadas aos perfis. As seções traçadas bem como a localização estão representadas nas figuras de 45 a 49 .

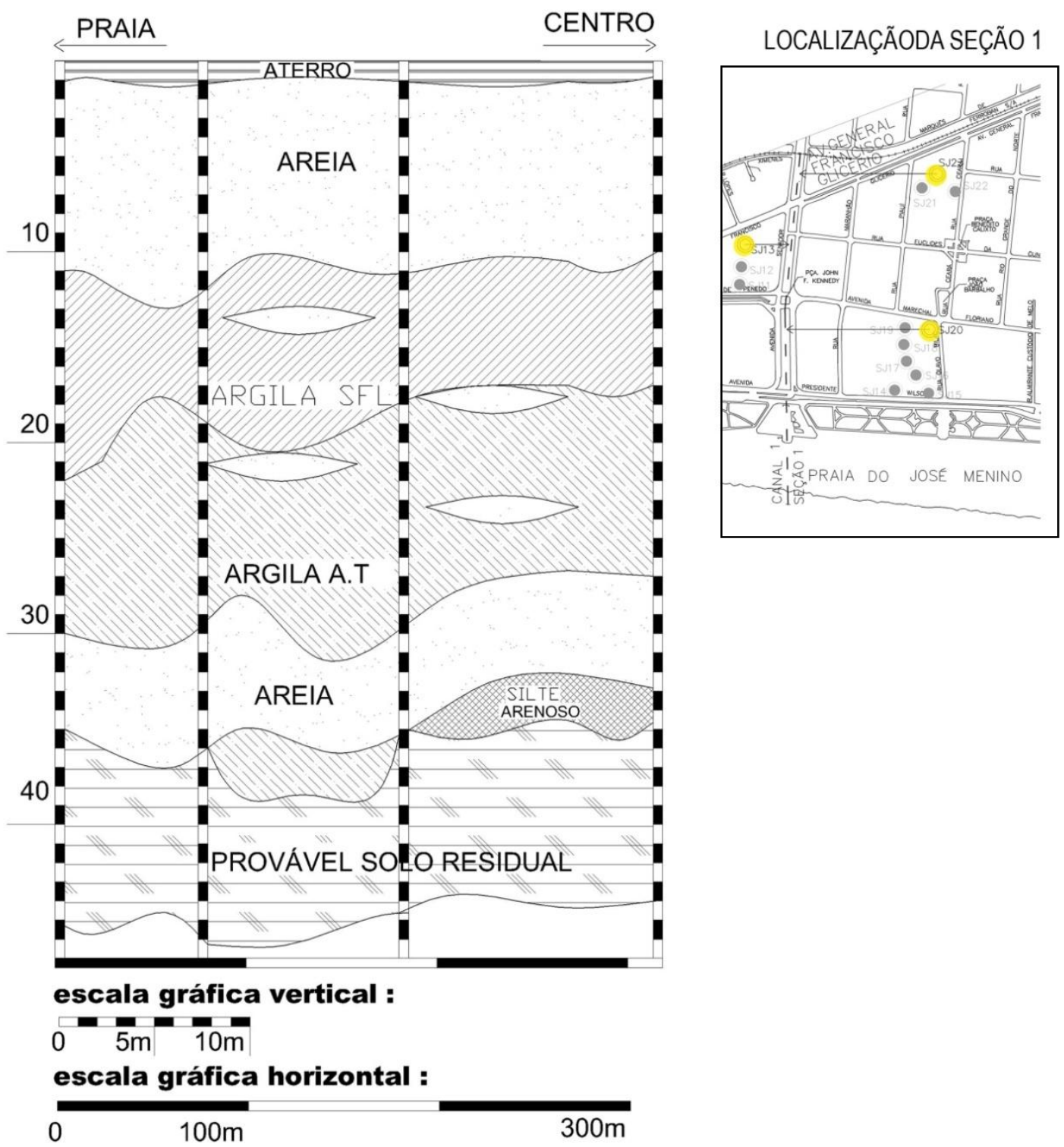

Figura 45 - Seção Transversal 1 sentido praia - centro (canal1). 


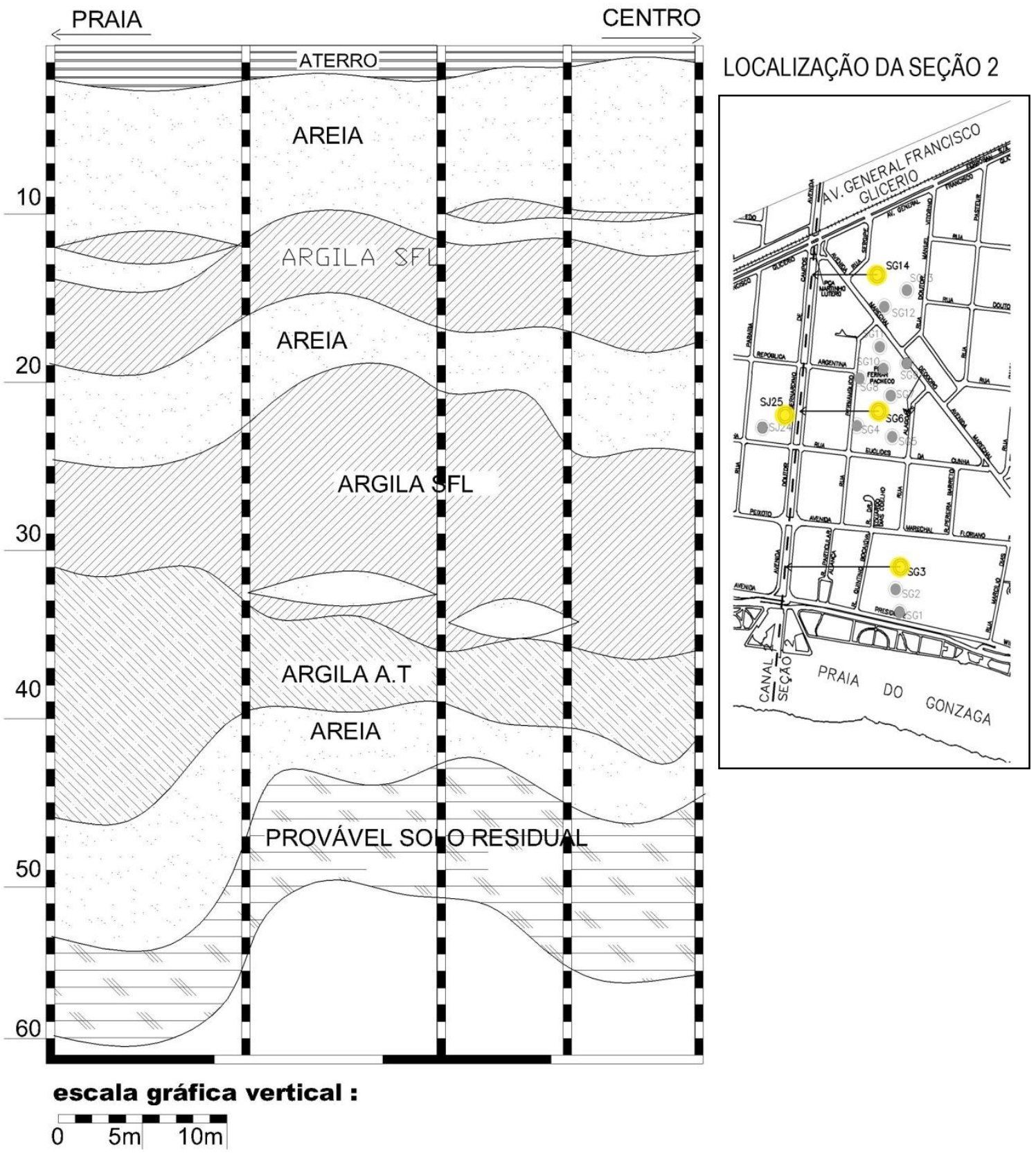

escala gráfica horizontal :

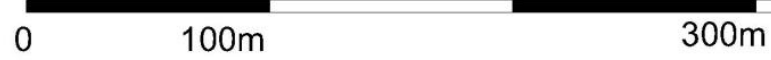

Figura 46 - Seção Transversal 2 sentido praia - centro (canal2). 


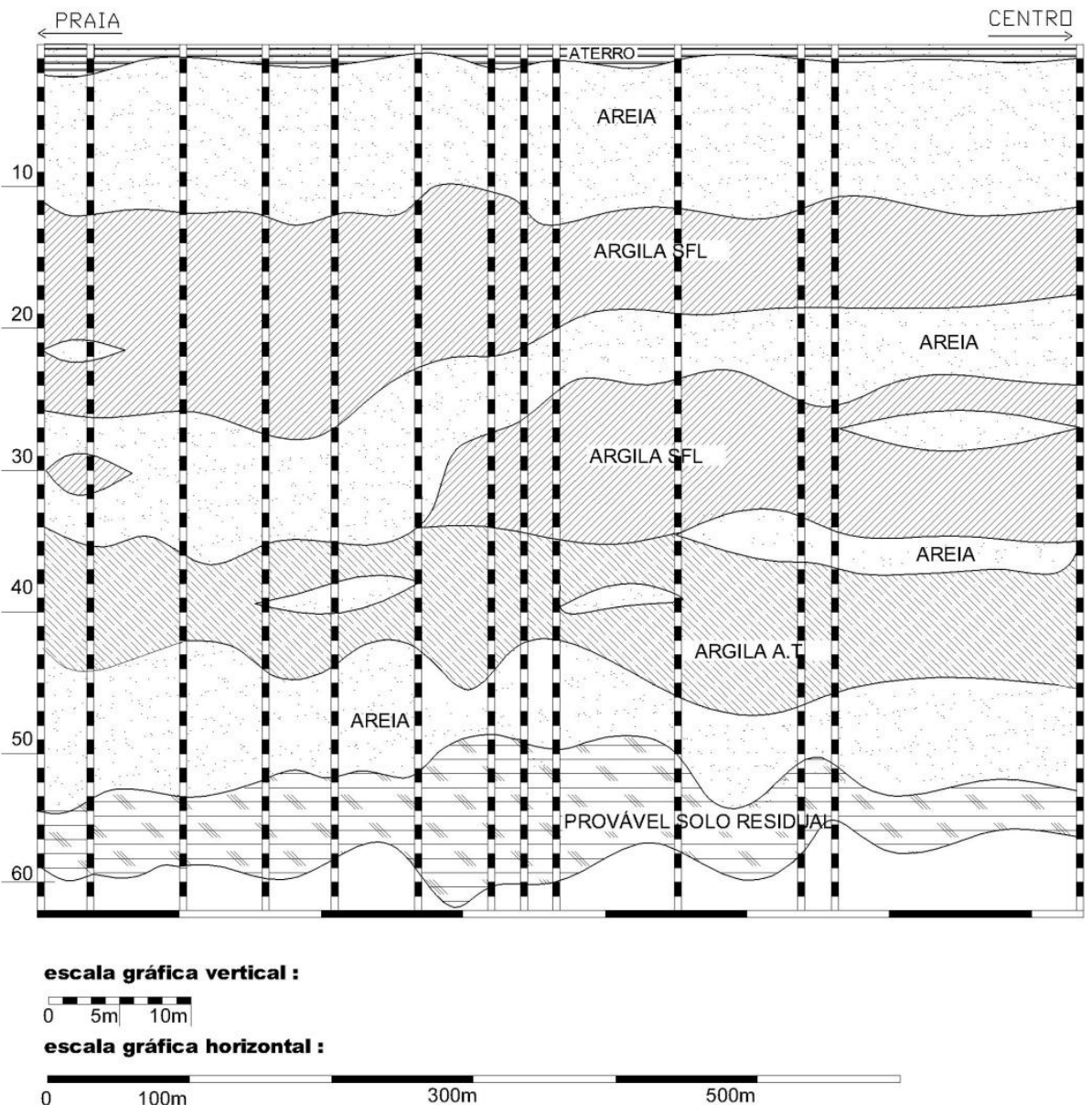

LOCALIZAÇÃO DA SEÇÃO 3

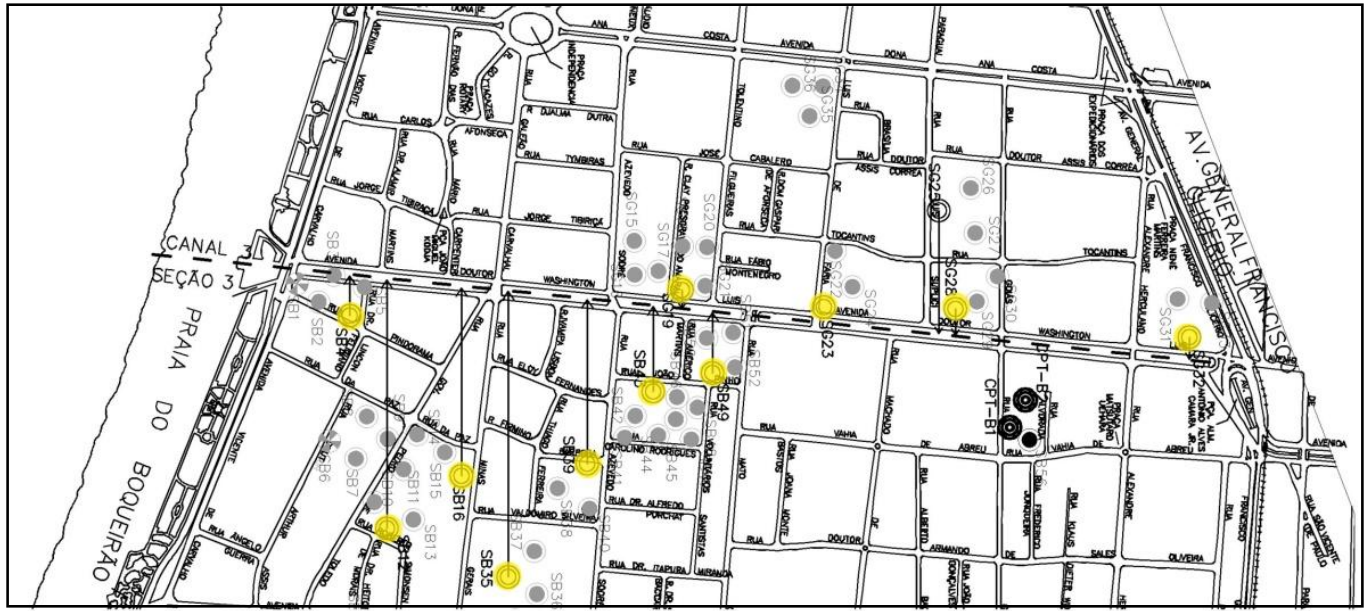

Figura 47 - Seção transversal 3 sentido praia - centro (canal 3) 


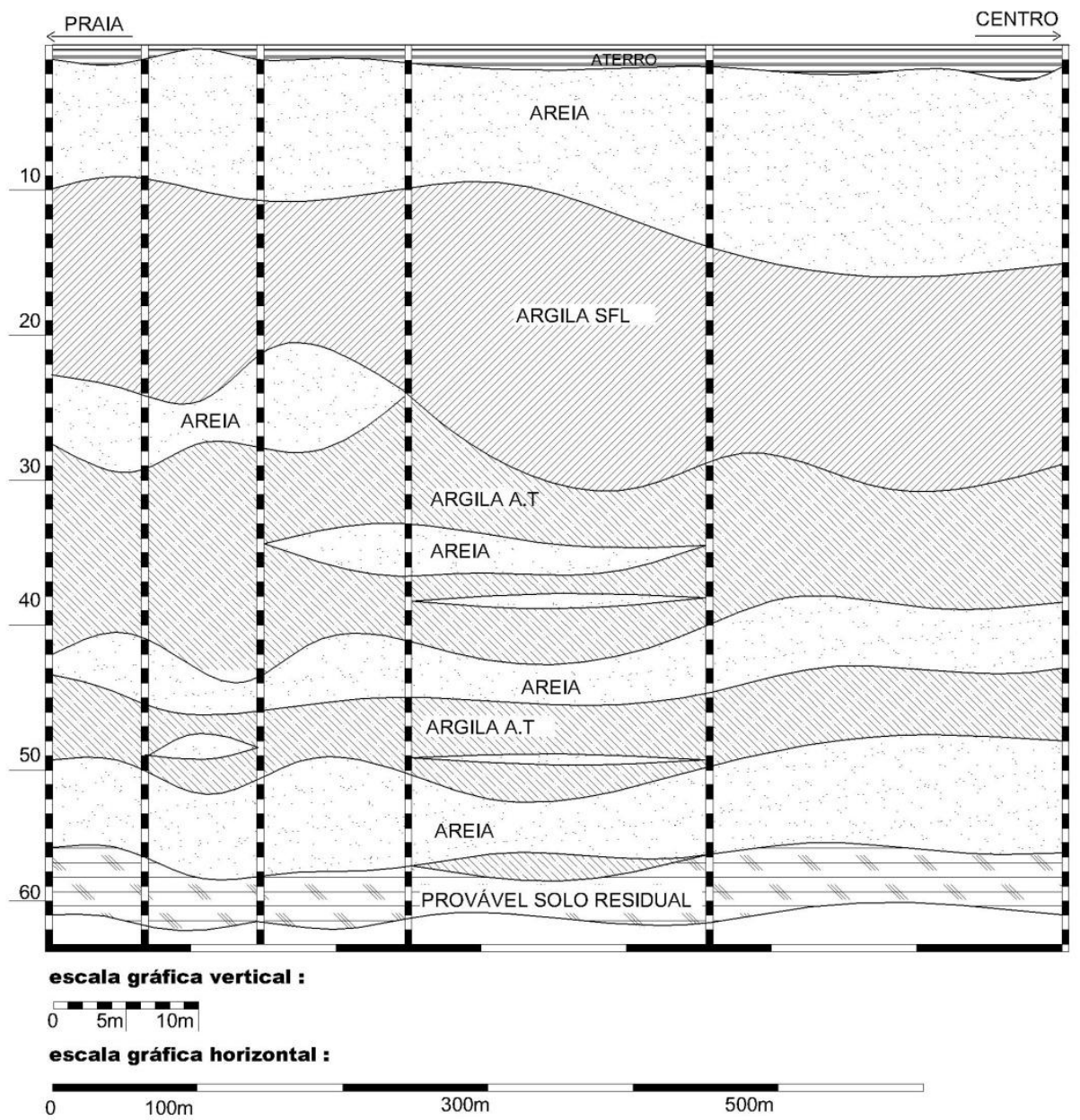

LOCALIZAÇÃO DA SEÇÃO 4

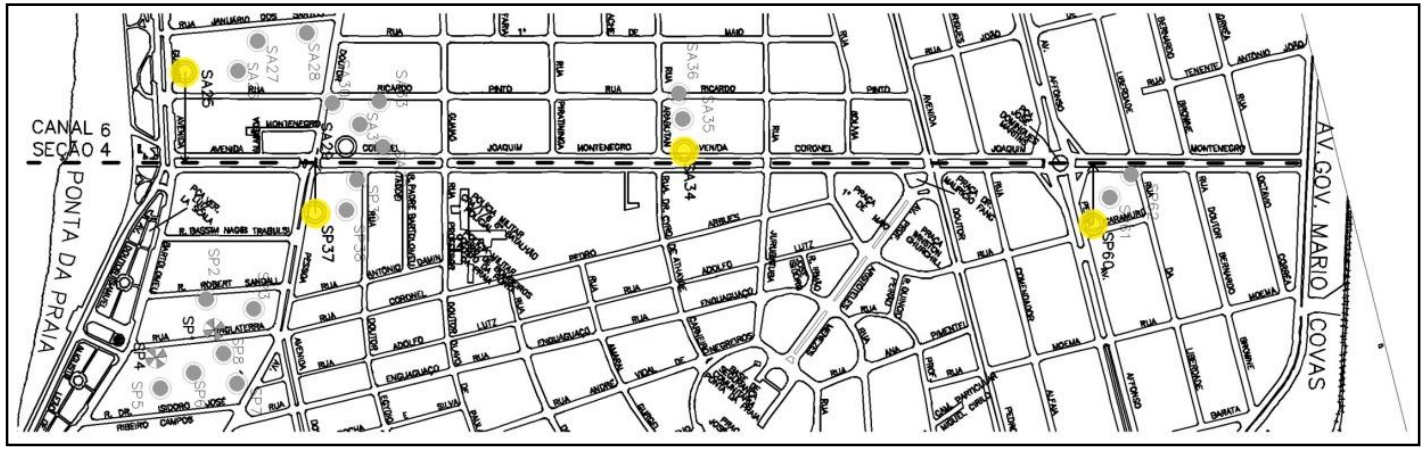

Figura 48 - Seção transversal 4 sentido praia - centro (canal 6) 


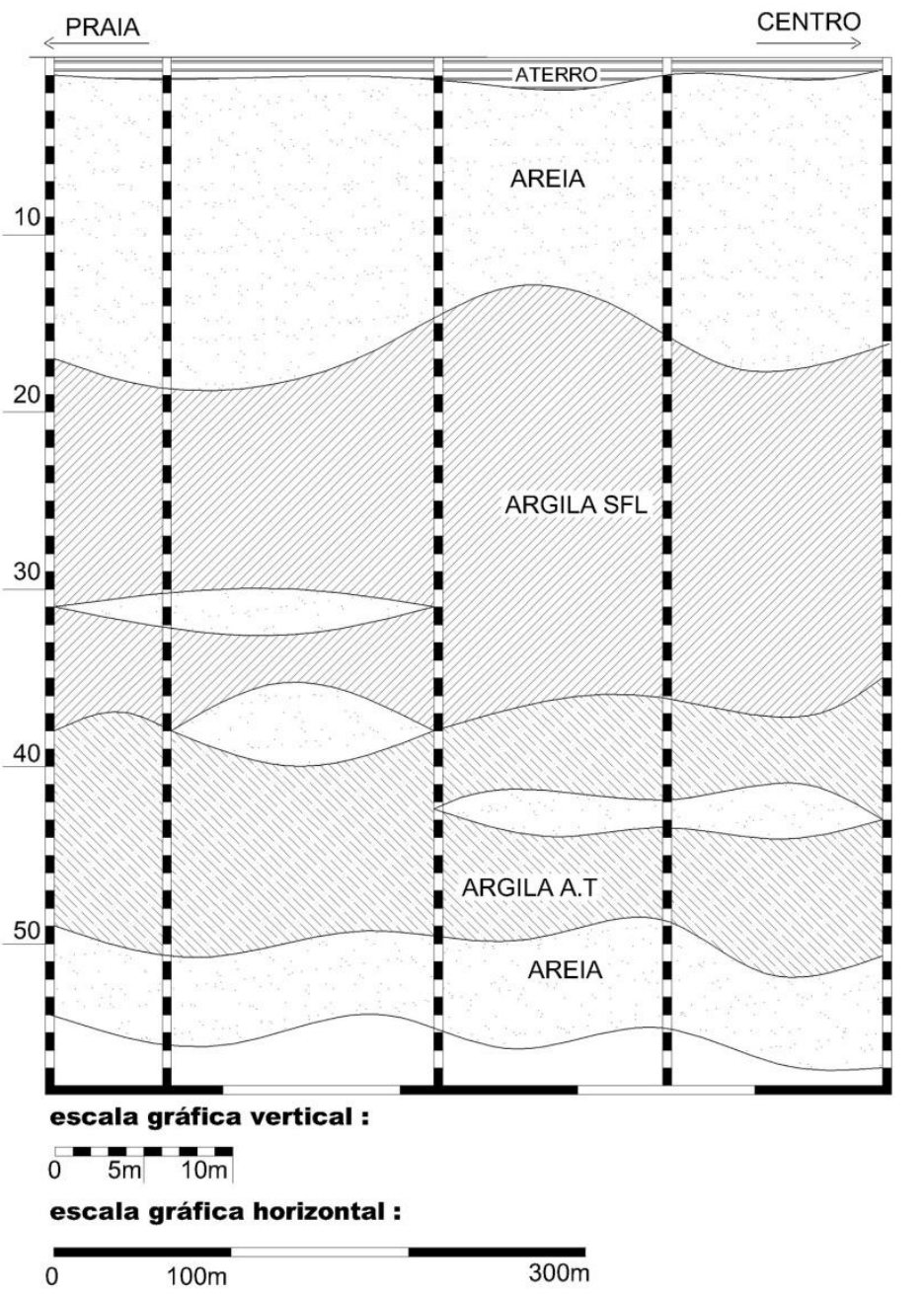

LOCALIZAÇÃO DA SEÇÃO 5

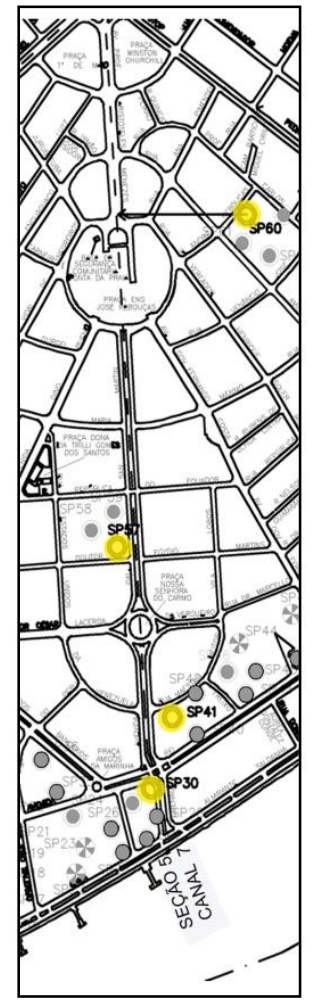

Figura 49 - Seção transversal 5 sentido praia - centro (canal 7)

\subsection{3 - Análise das seções transversais}

Em uma breve análise sobre as seções transversais traçadas, observa-se que 0 subsolo da cidade de Santos não varia muito à medida que se afasta da praia, exceto é claro nas regiões próximas aos morros da cidade, onde a rocha é aflorante.

De uma maneira geral ocorrem camadas de argila SFL, AT e areias muito e pouco compactas. Nota-se uma tendência das camadas de argila SFL e AT se juntarem, assim como no bairro da Ponta da Praia, não havendo uma camada de areia bem definida entre as argilas, como na "Faixa Crítica". 


\section{CAPÍTULO V - CONCLUSÕES e SUGESTÕES}

\section{1 - CONCLUSÕES}

Com a análise das sondagens, foi possível readaptar o perfil geotécnico da orla de Santos na região de aproximação com o Guarujá (figura 43) e traçar a seção geotécnica do bairro da Ponta da Praia (figura 44) e traçar seções transversais à orla de Santos (figura 45 a 49), conforme proposto no início do trabalho.

Verificou-se que a primeira camada de areia tem um aumento significativo no Bairro da Ponta da Praia, atingindo mais de $23,0 \mathrm{~m}$. Após a travessia da balsa, já no Guarujá, essa camada de areia tende a desaparecer.

Observou-se também que embora a camada de areia na Ponta da Praia seja mais espessa, apresentou valores de $\mathrm{N}_{\mathrm{SPT}}$ médio menores em relação às outras regiões estudadas. Além das análises das sondagens de simples reconhecimento, parâmetros geotécnicos obtidos através dos ensaios do cone comprovaram as diferenças entre o bairro da Ponta da praia e da "Faixa Crítica". Destacaram-se as propriedades da primeira camada de areia para as duas regiões. Comprovou-se através dos valores do ângulo de atrito, módulo de elasticidade, resistência de ponta, que a "Faixa Crítica" possui uma areia mais compacta e resistente que a Ponta da Praia.

A presença de camadas de argila bem profundas, com valores de $\mathrm{N}_{\mathrm{SPT}}$ elevados, causa certa dúvida quanto à sua origem, sedimentos continentais ou solos residuais, e quanto à possibilidade de sua ocorrência em outras regiões da Orla de Santos. Dessa forma, os perfis abaixo dos 50-60 m de profundidade continuam com pontos de interrogação. 
Quanto às seções transversais traçadas, pode-se notar uma tendência das camadas de argila SFL e AT se juntarem, no sentido centro. As camadas de areia intermediárias não são tão definidas quanto na orla da Santos em muitas sondagens elas aparecem em pequenas espessuras entre as camadas de argila.

Cálculos para a previsão de recalques, admitindo oscilação negativa do nível do mar como mecanismo de sobreadensamento, mostraram que o aumento da espessura da primeira camada de areia, no bairro da Ponta da Praia, contribuiu para que os recalques fossem cerca de 2 vezes menores que na "Faixa Crítica".

Verificou-se que ação de dunas no passado pode ter contribuido na diminuição dos recalques de seis a oito vezes se comparados com o efeito das elevações do nível do mar, dependendo da região.

Ficou claro que a ação de Dunas no passado e a espessa camada de areia na Ponta da Praia foram determinantes para que o cenário do bairro se tornasse diferente do restante da orla da Santos, ou seja, sem prédios visivelmente recalcados e inclinados.

\section{2 - SUGESTÕES PARA CONTINUIDADE DA PESQUISA}

Seguir a mesma linha de pesquisa, em direção aos canais um e dois, que não foram estudados nesse trabalho

Traçar novas seções transversais, seguindo os demais canais e inserir novas sondagens nas seções já traçadas

Realizar novos ensaios do cone CPT e CPTU nos bairros que não foram abordados nessa pesquisa e confrontar os com os dados apresentados 


\section{ANEXO A - SONDAGENS DE REFERÊNCIA BAIRRO BOQUEIRÃO (canal 3 - canal4)}



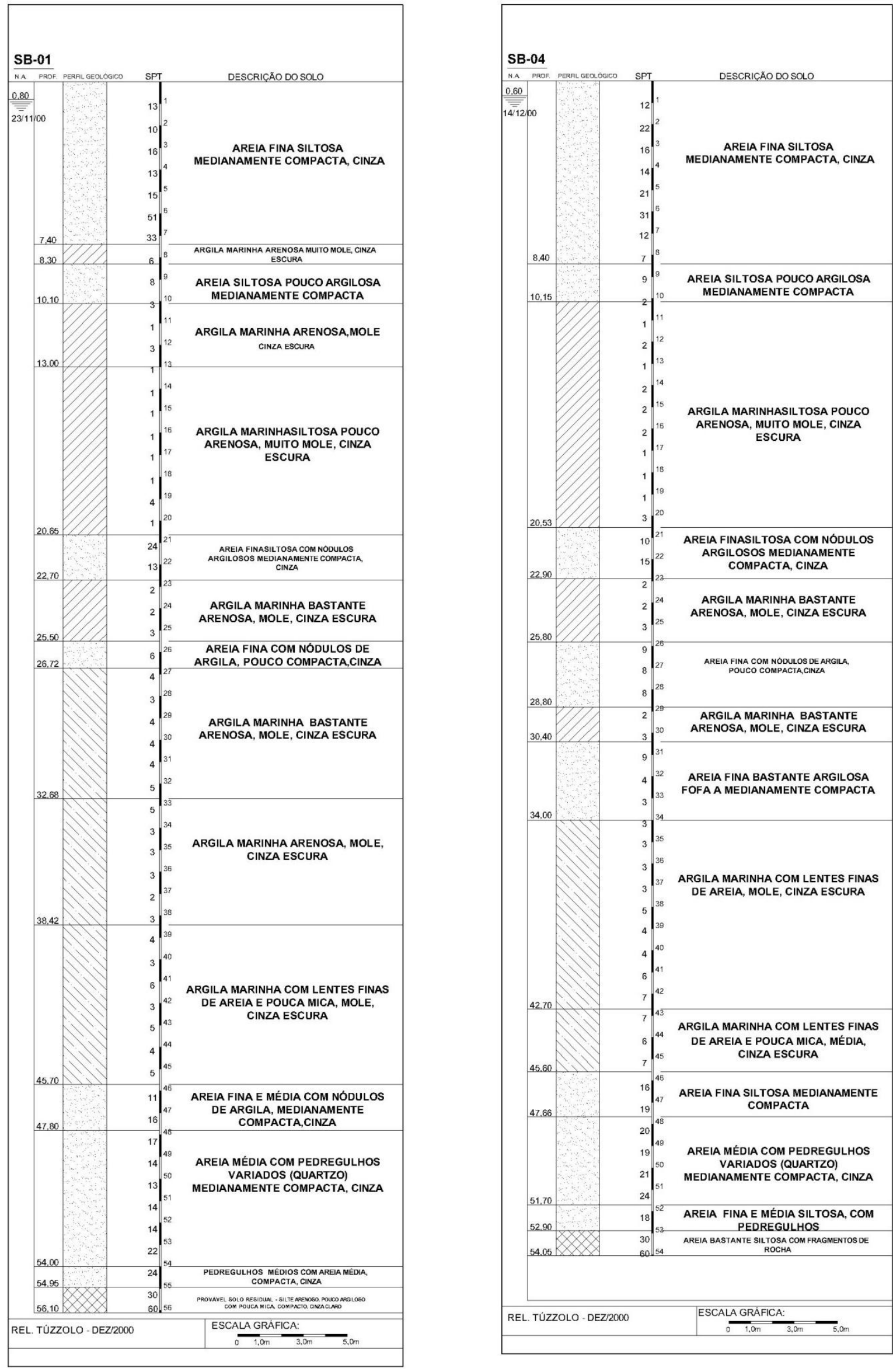

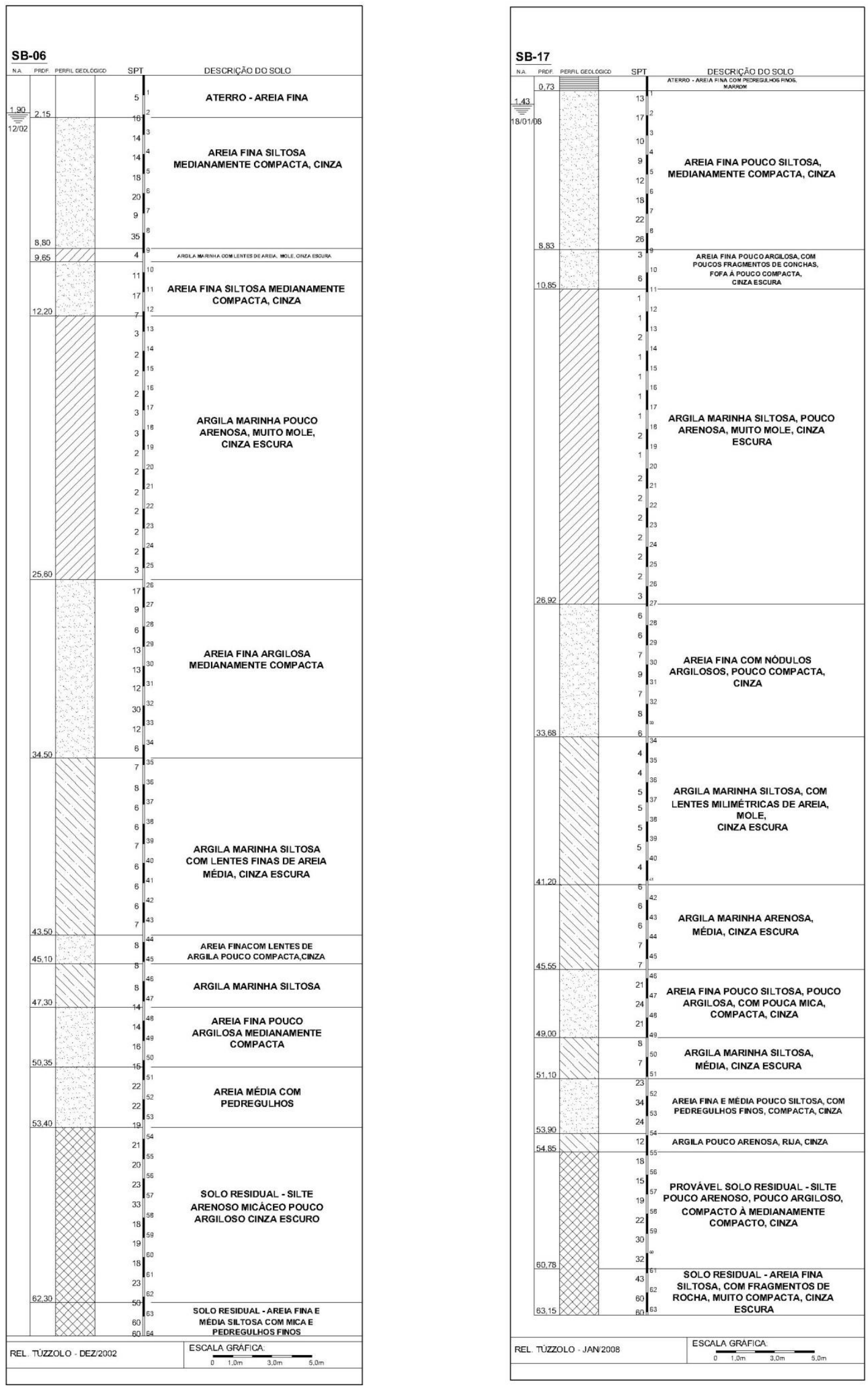

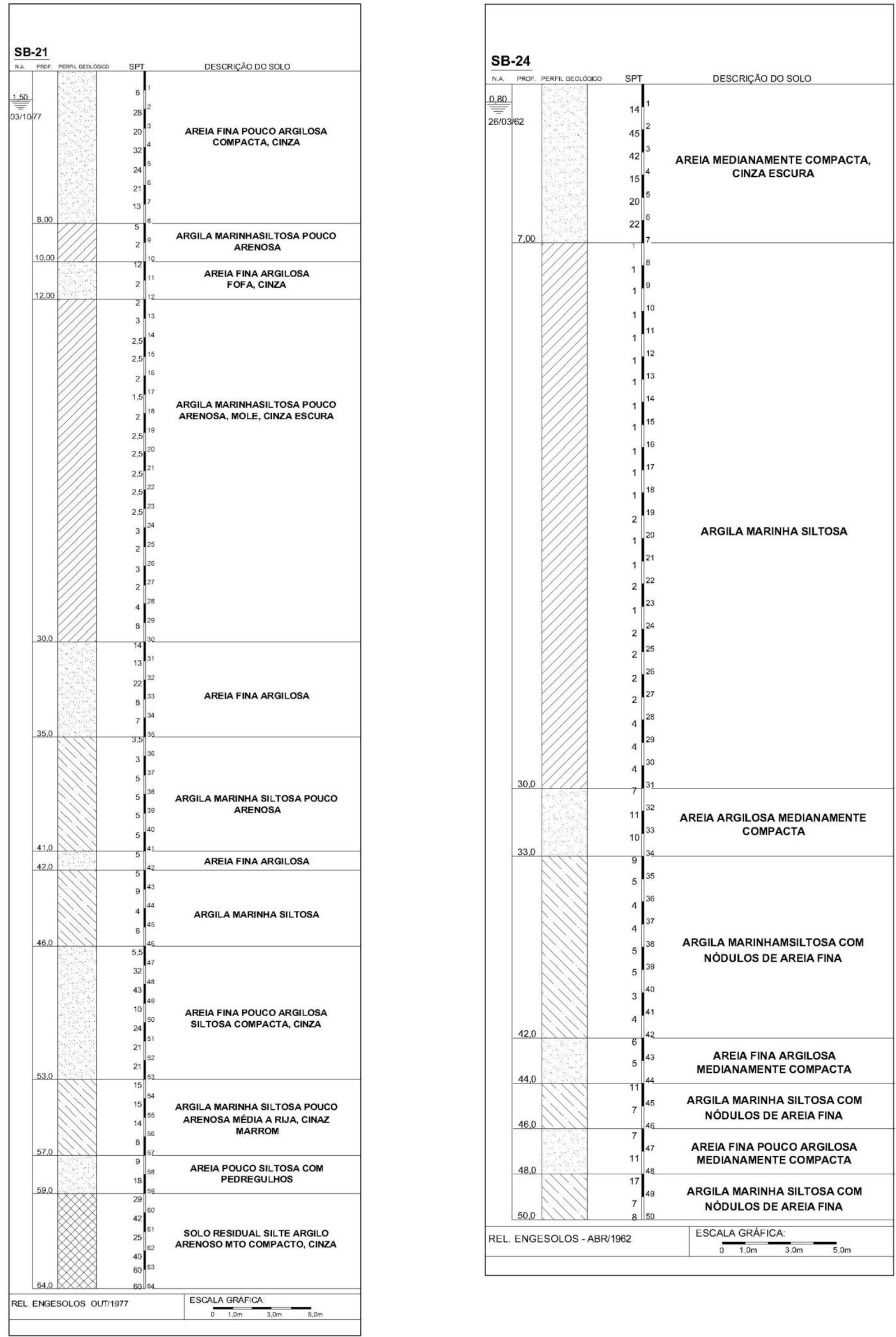

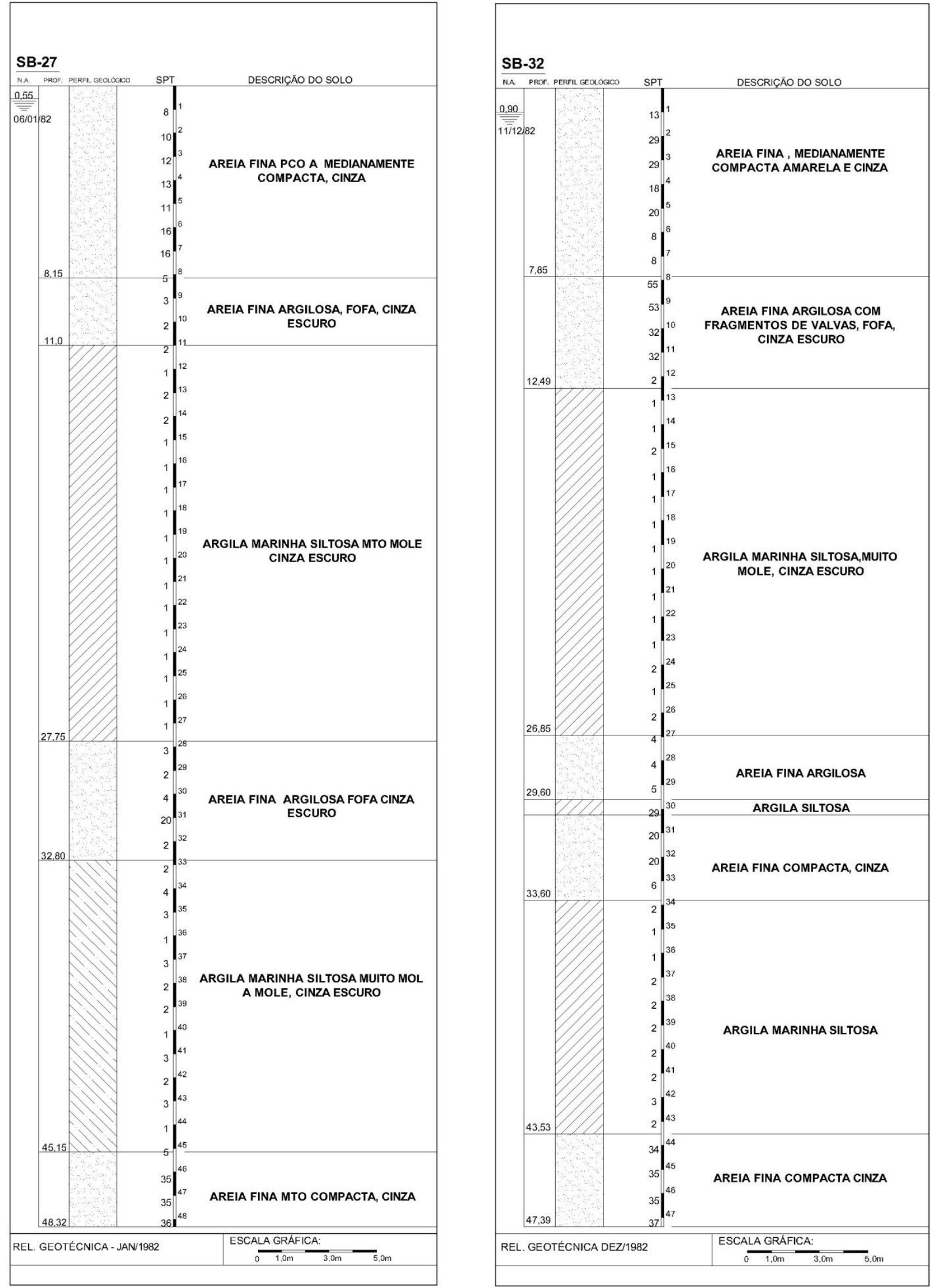


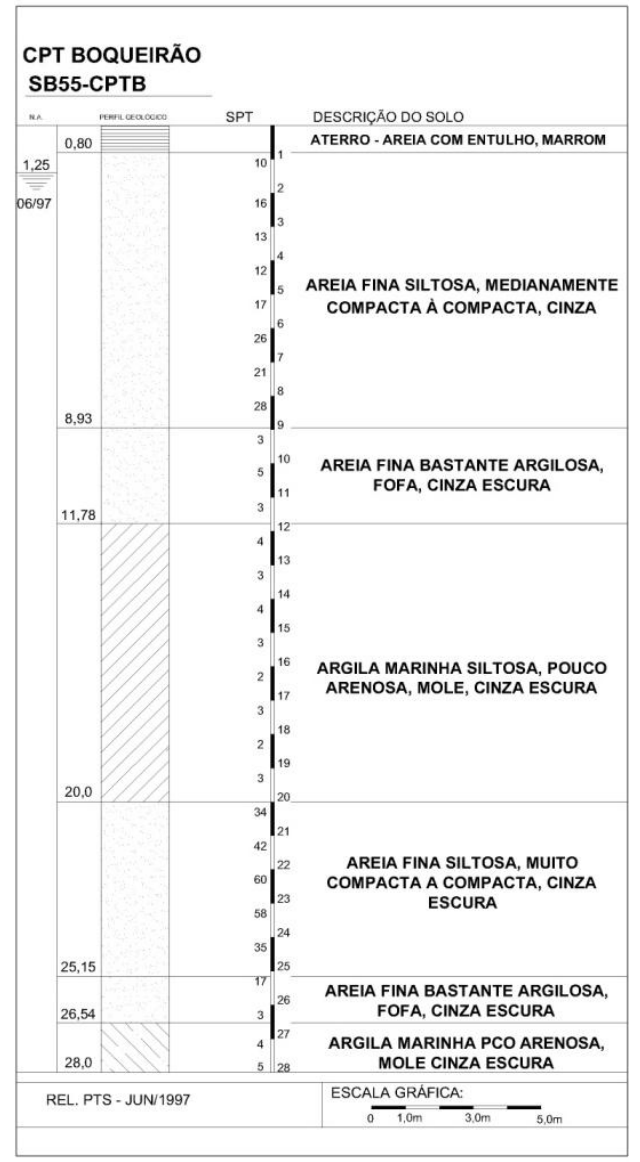

\section{ESTRATIGRAFIA SB53, CPTU 01 e CPTU 03} SB53 - CPTU

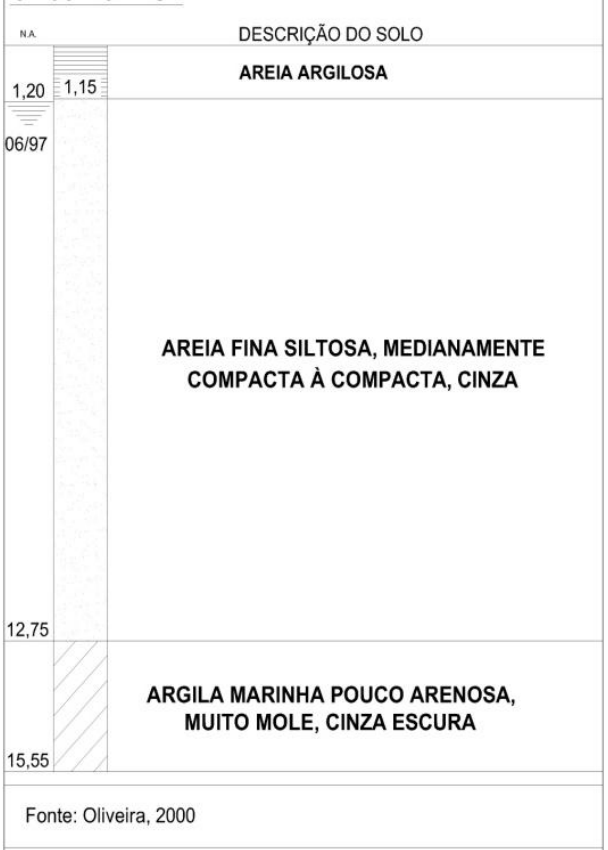

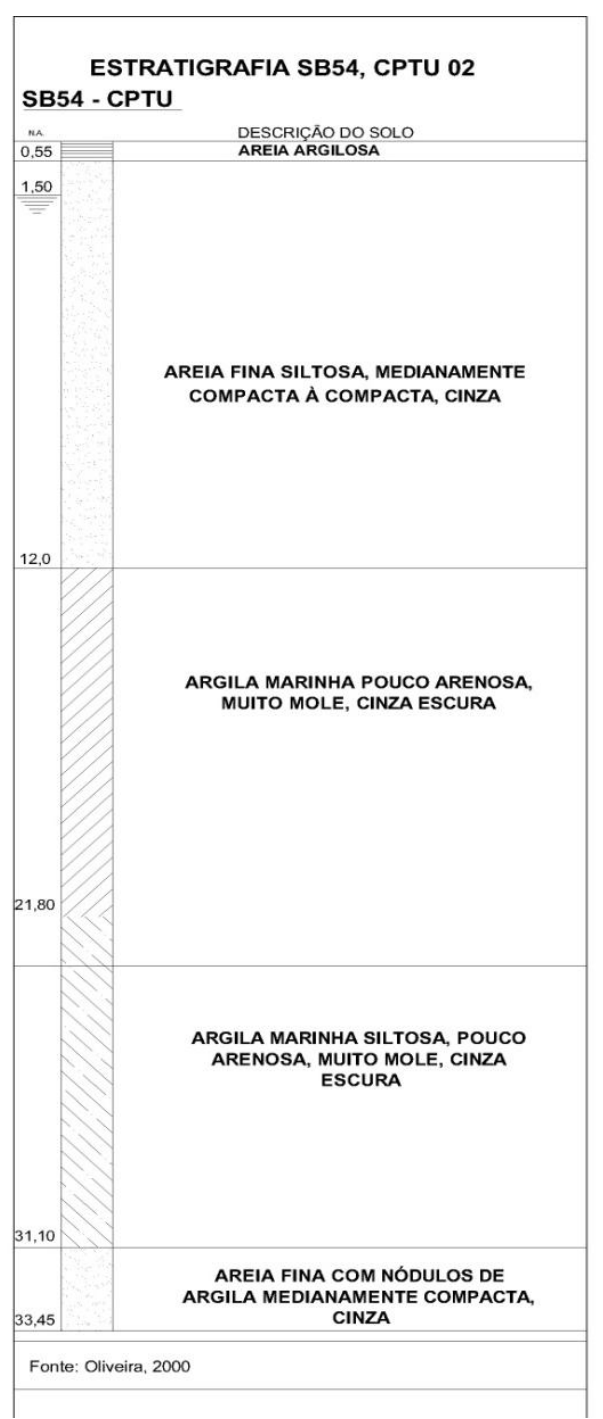


ANEXO B - SONDAGENS DE REFERÊNCIA BAIRRO

EMBARÉ (canal 4 - canal 5) 

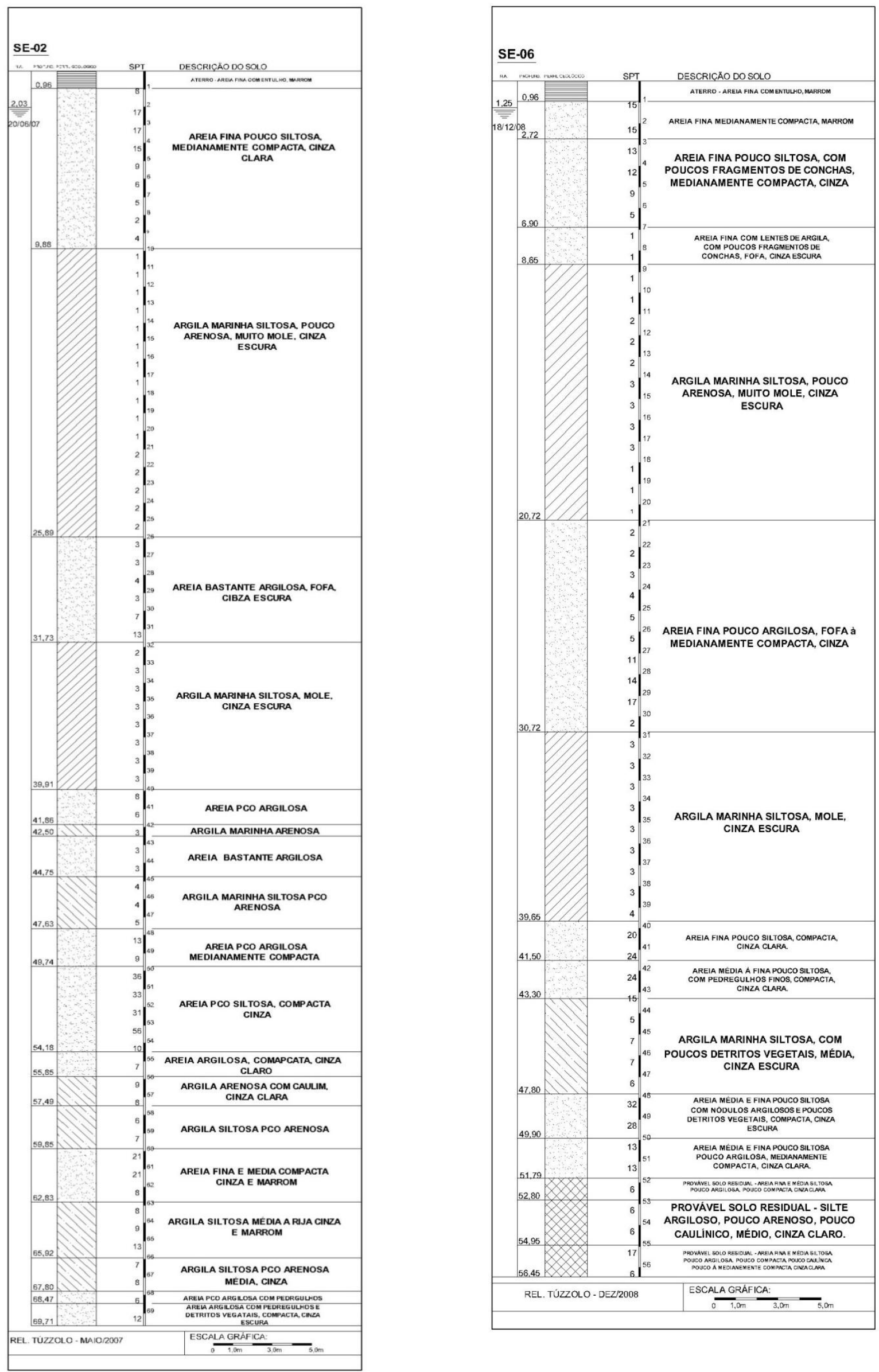

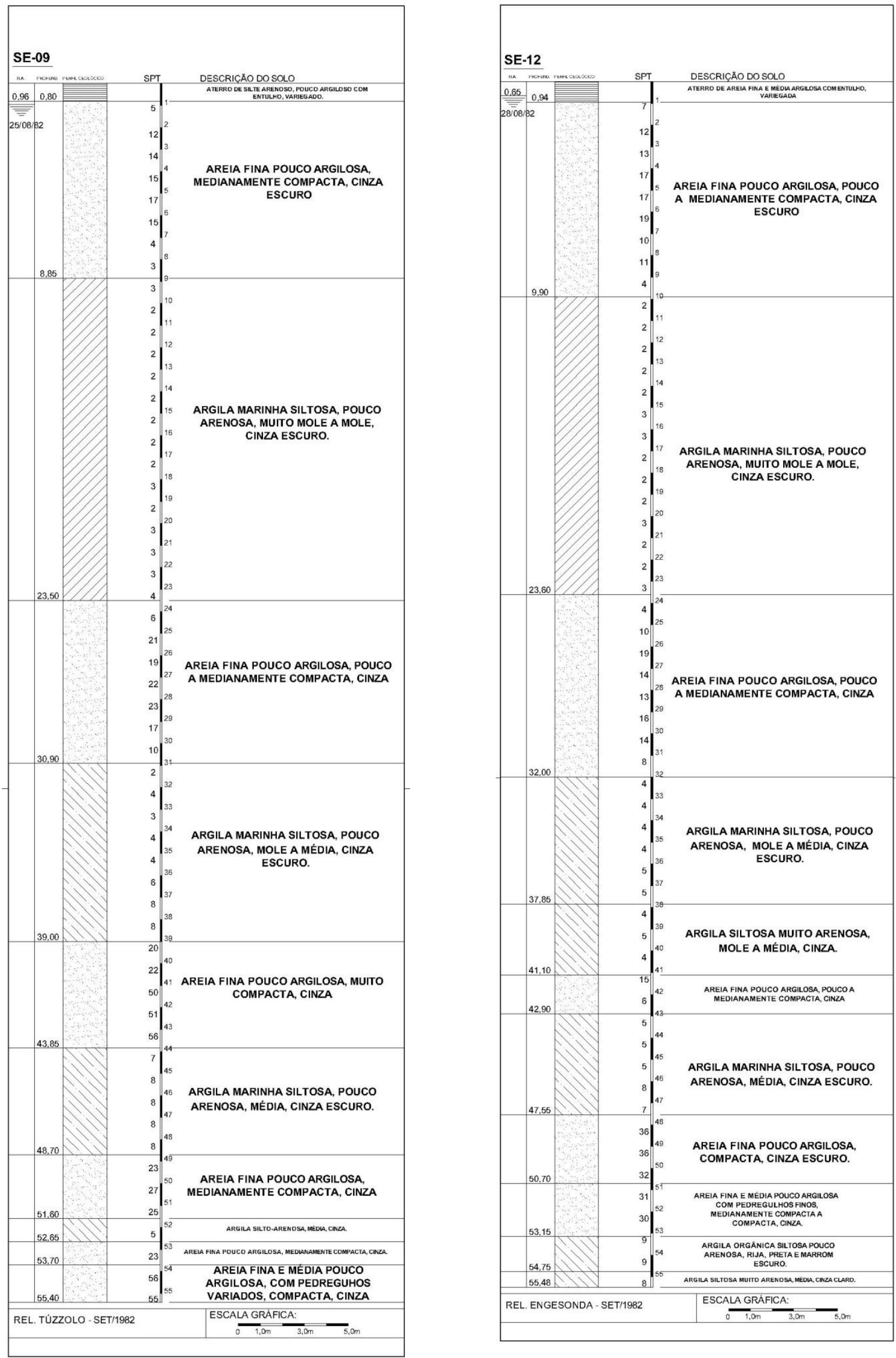

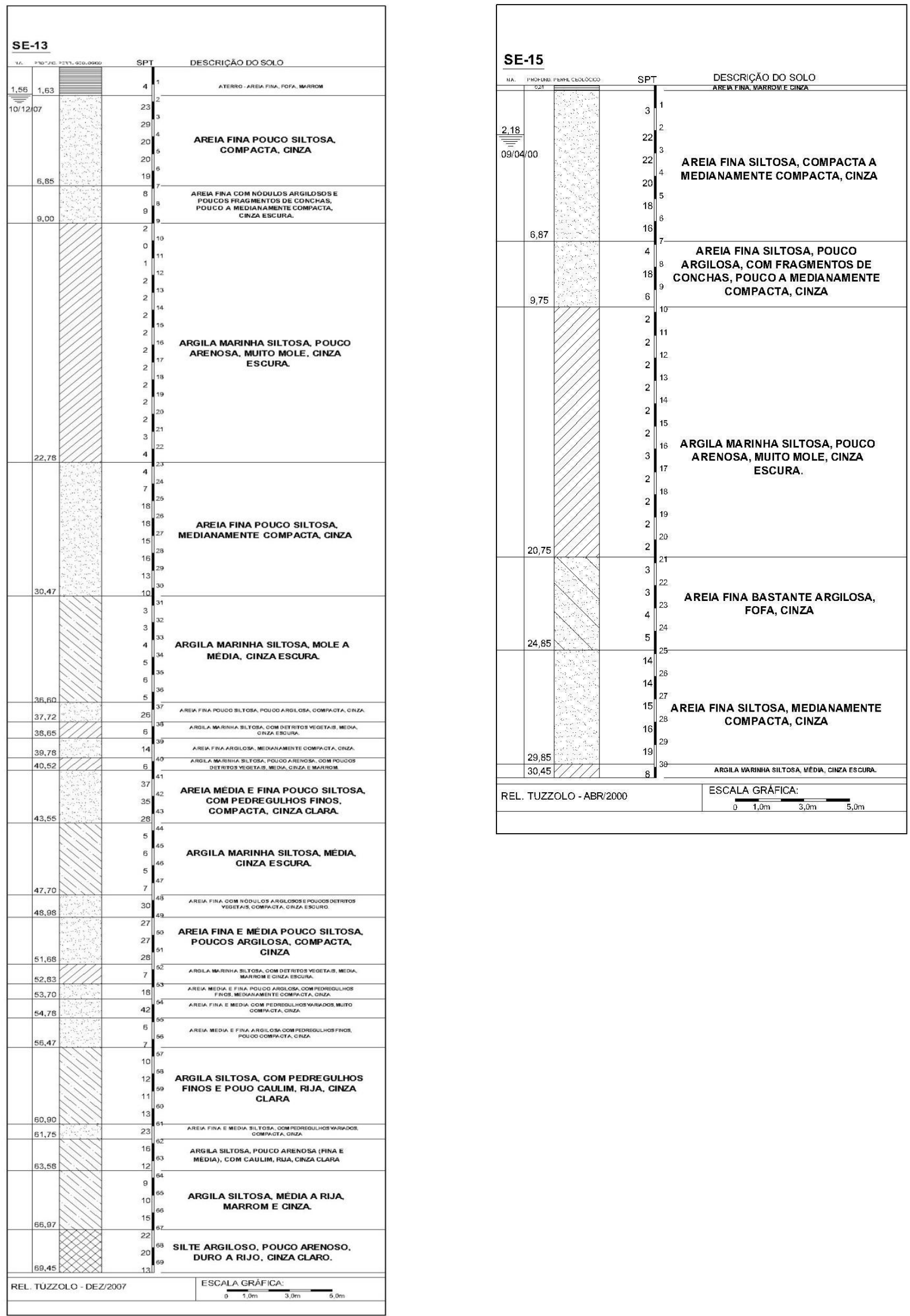


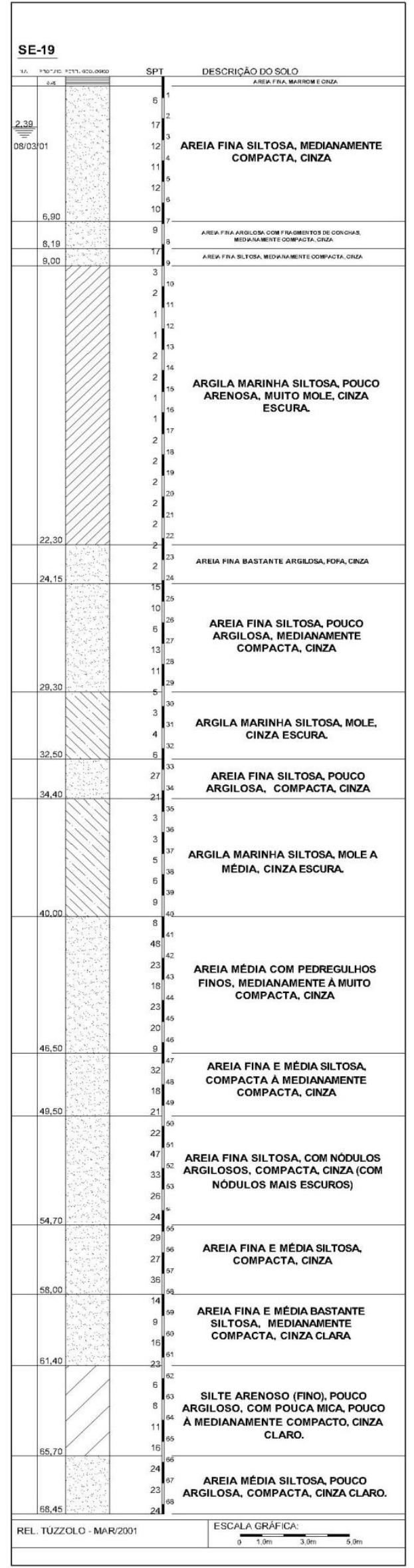

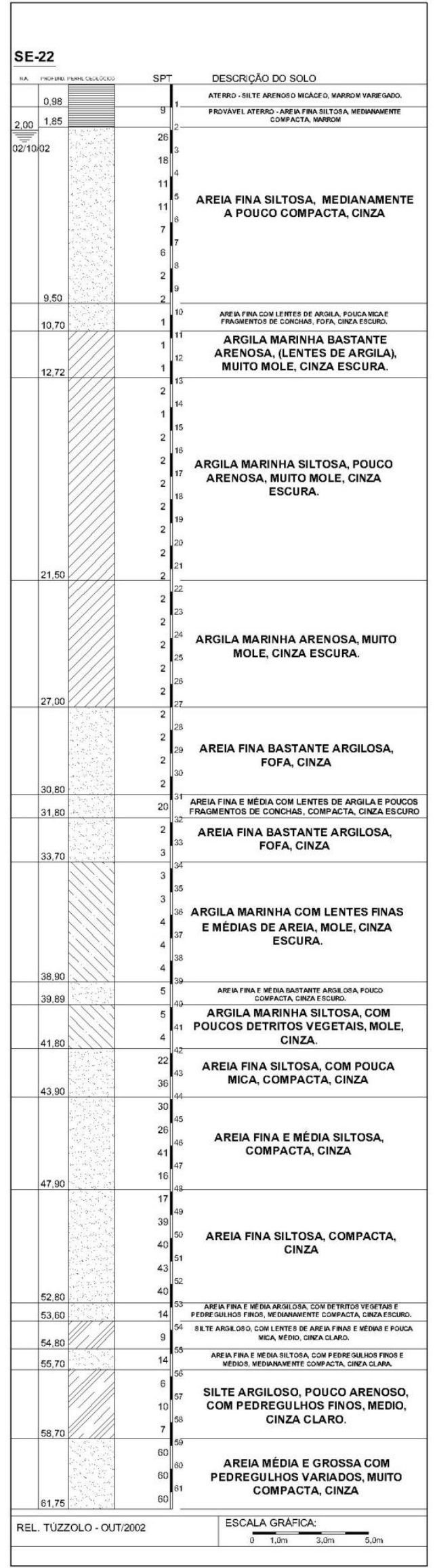




\section{ANEXO C - SONDAGENS DE REFERÊNCIA BAIRRO APARECIDA (canal 5 - canal 6 )}



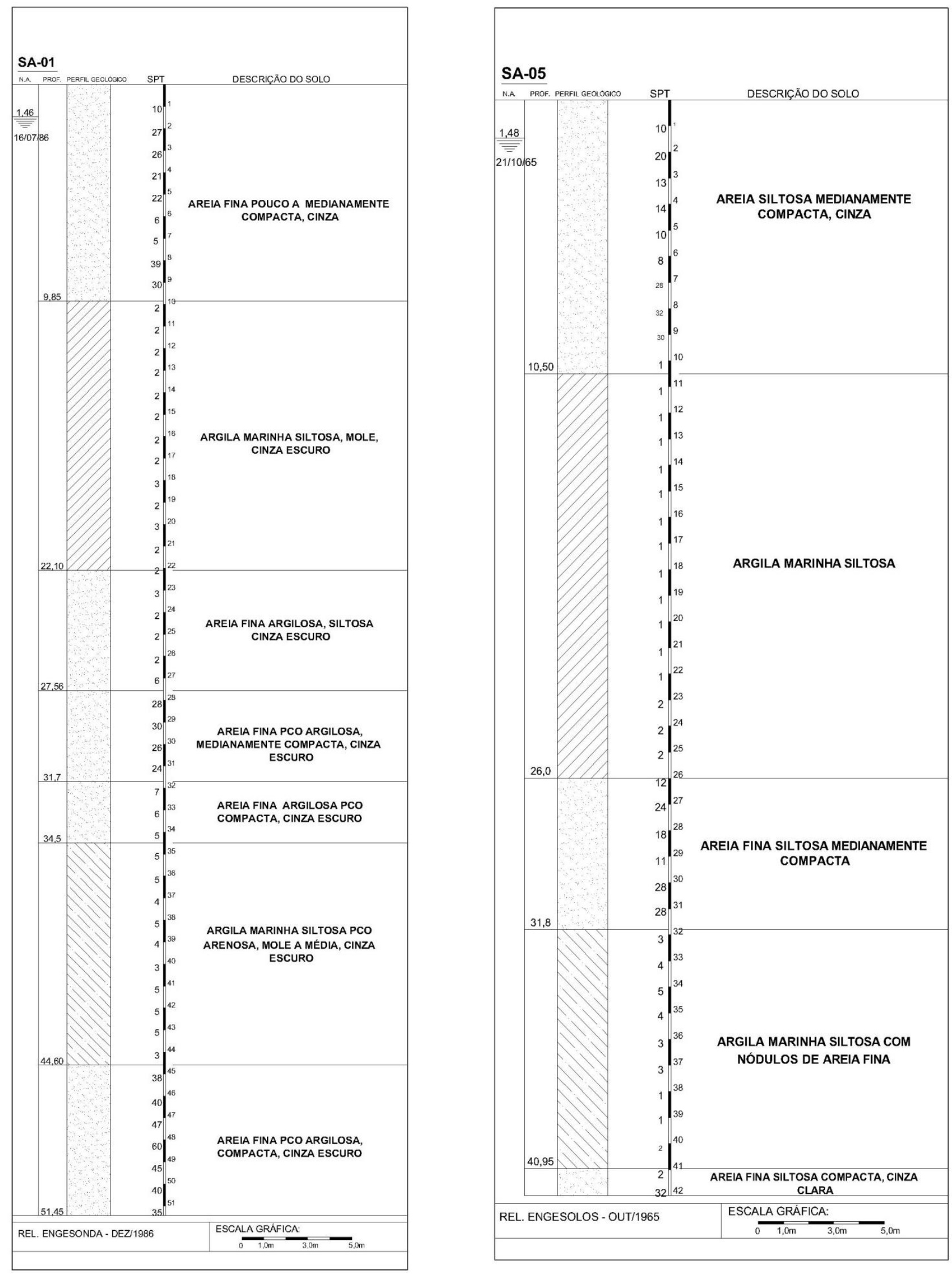

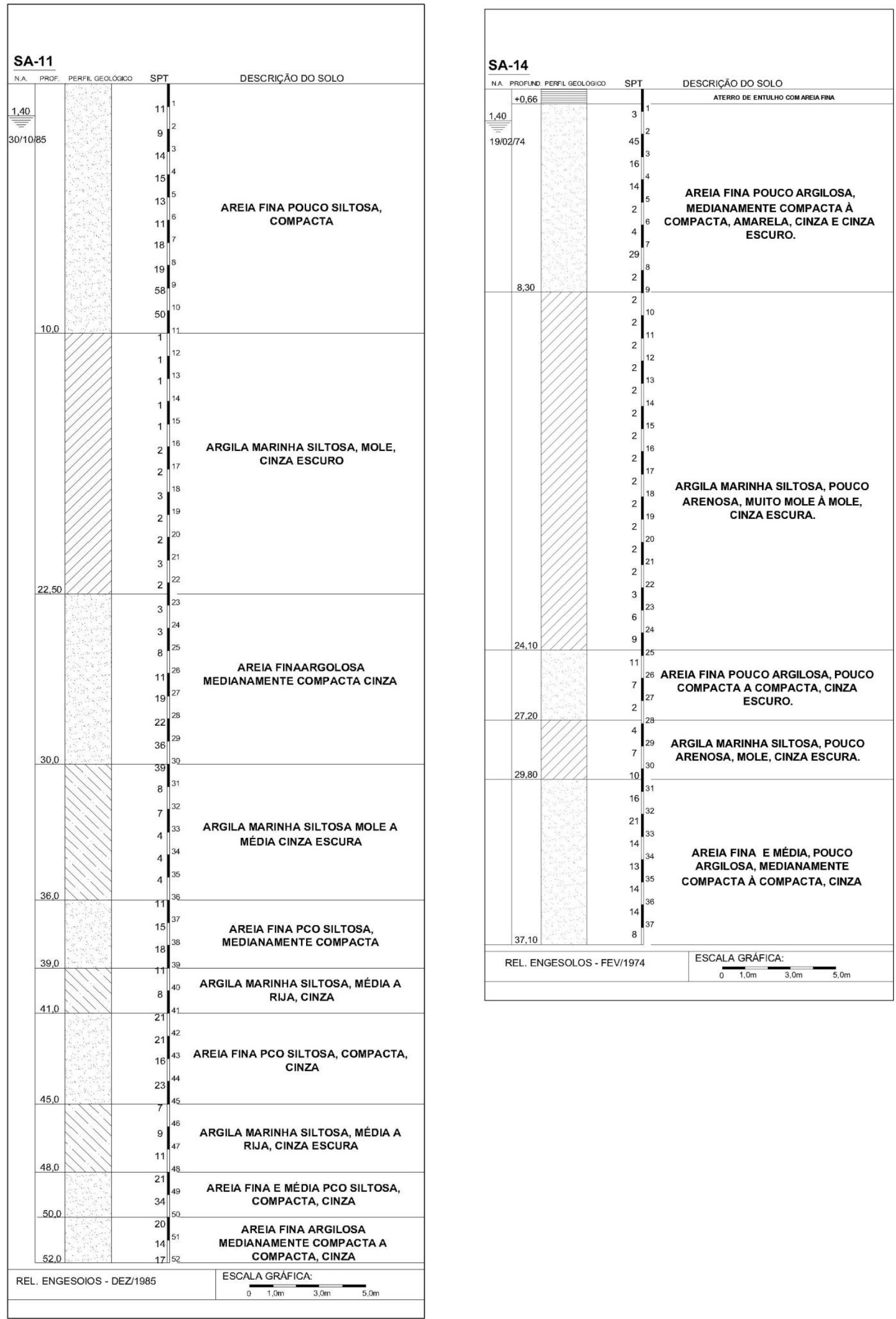

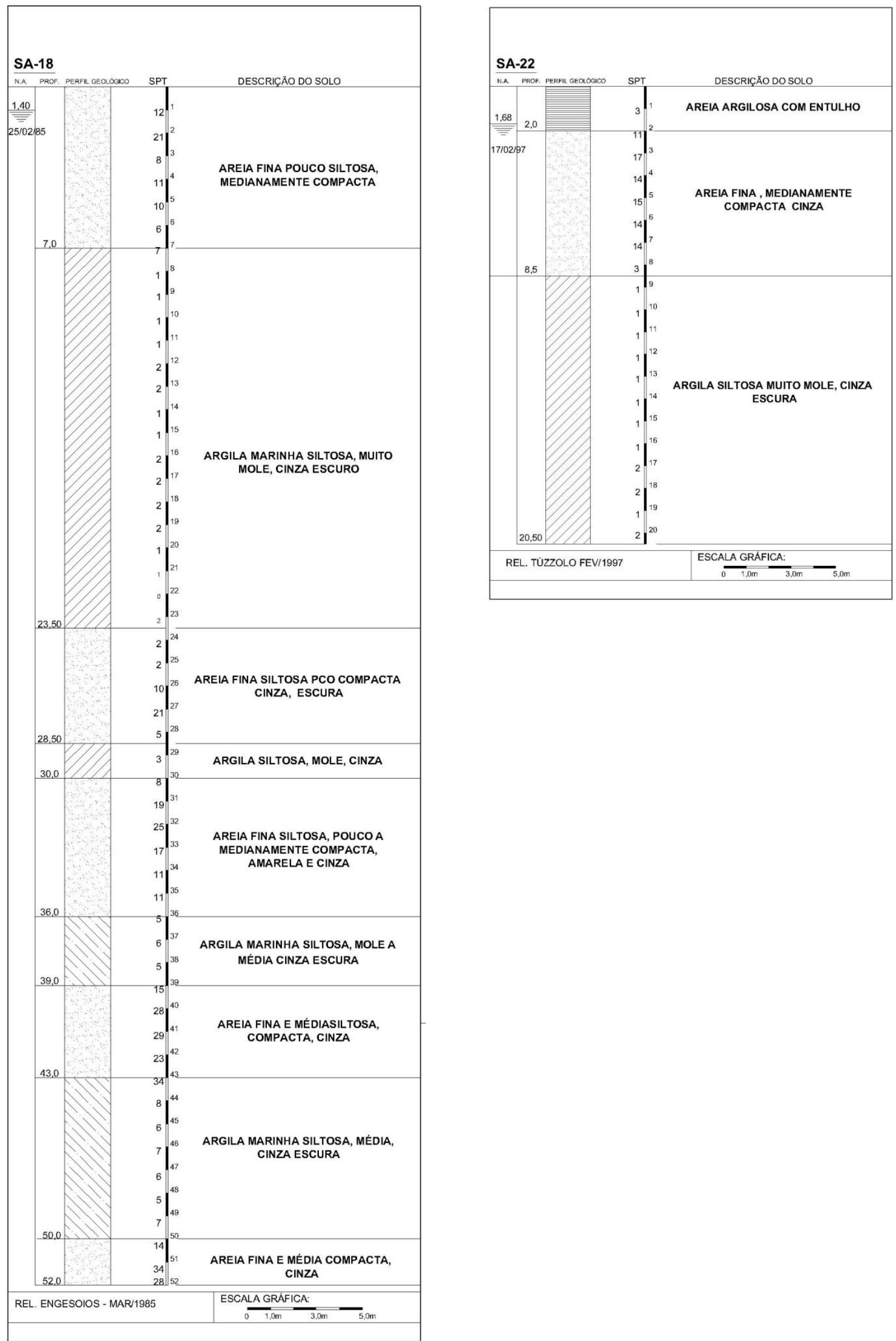

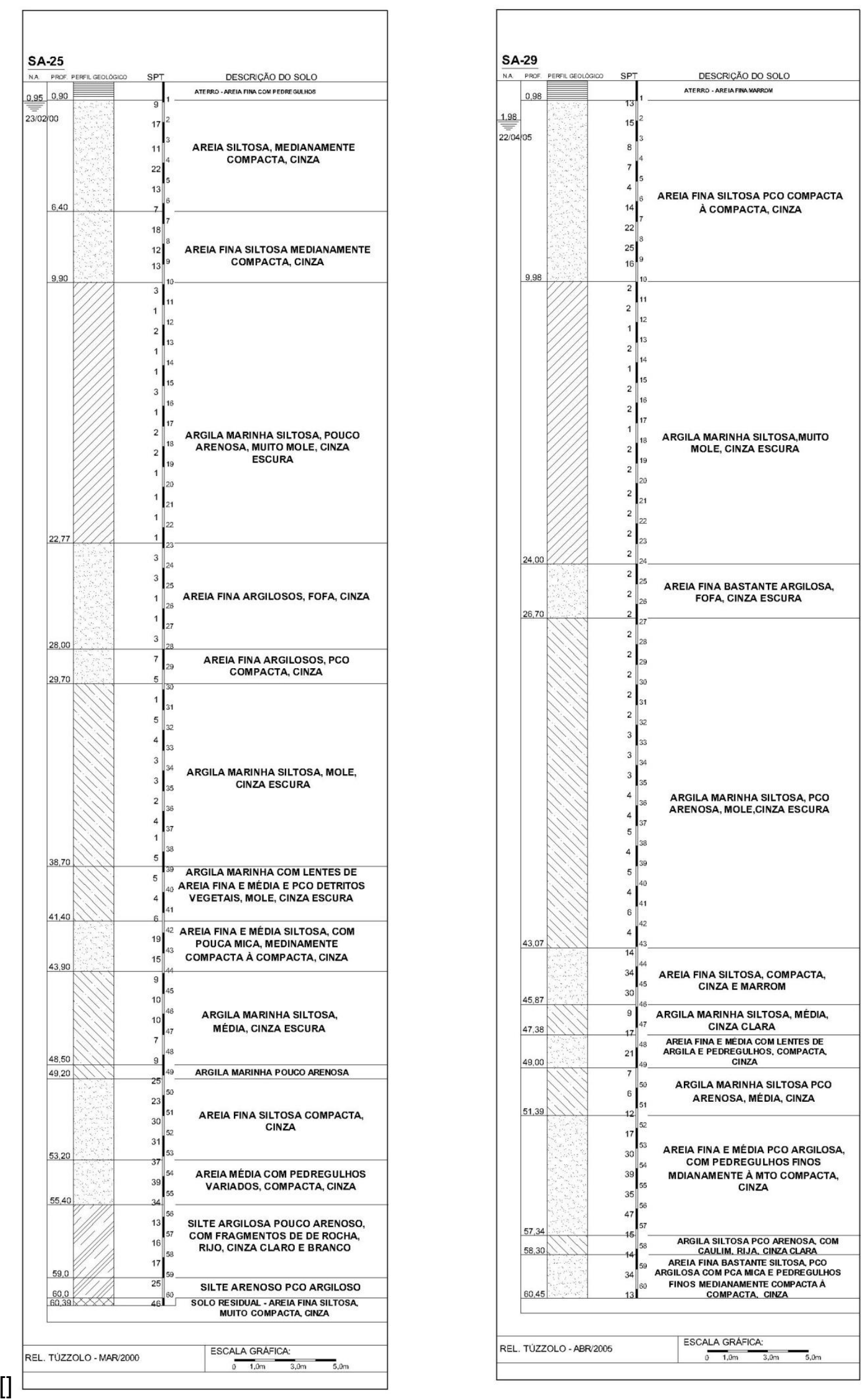


\section{ANEXO D - SONDAGENS DE REFERÊNCIA BAIRRO PONTA DA PRAIA (canal 6 - Ferry Boat)}



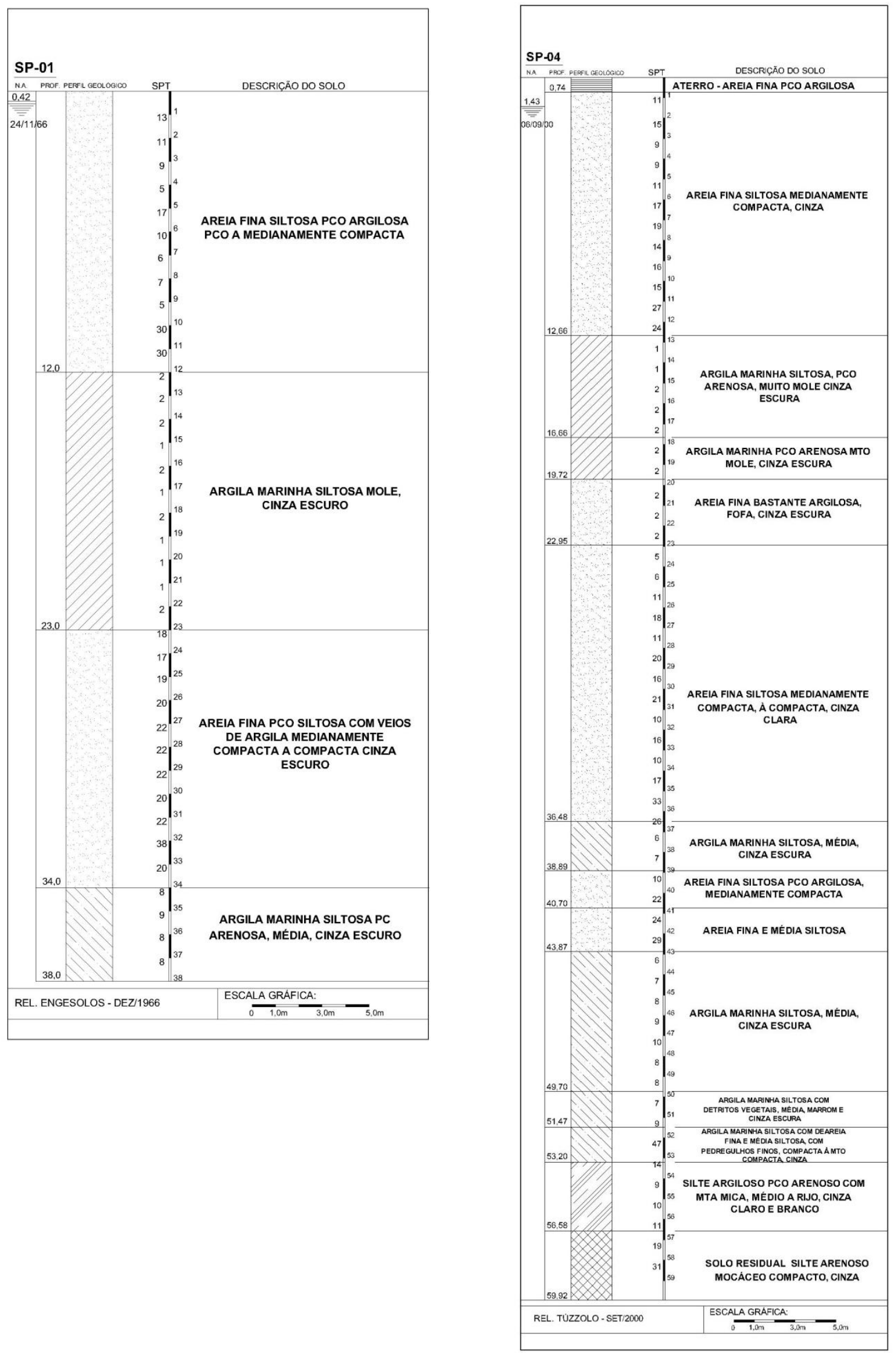

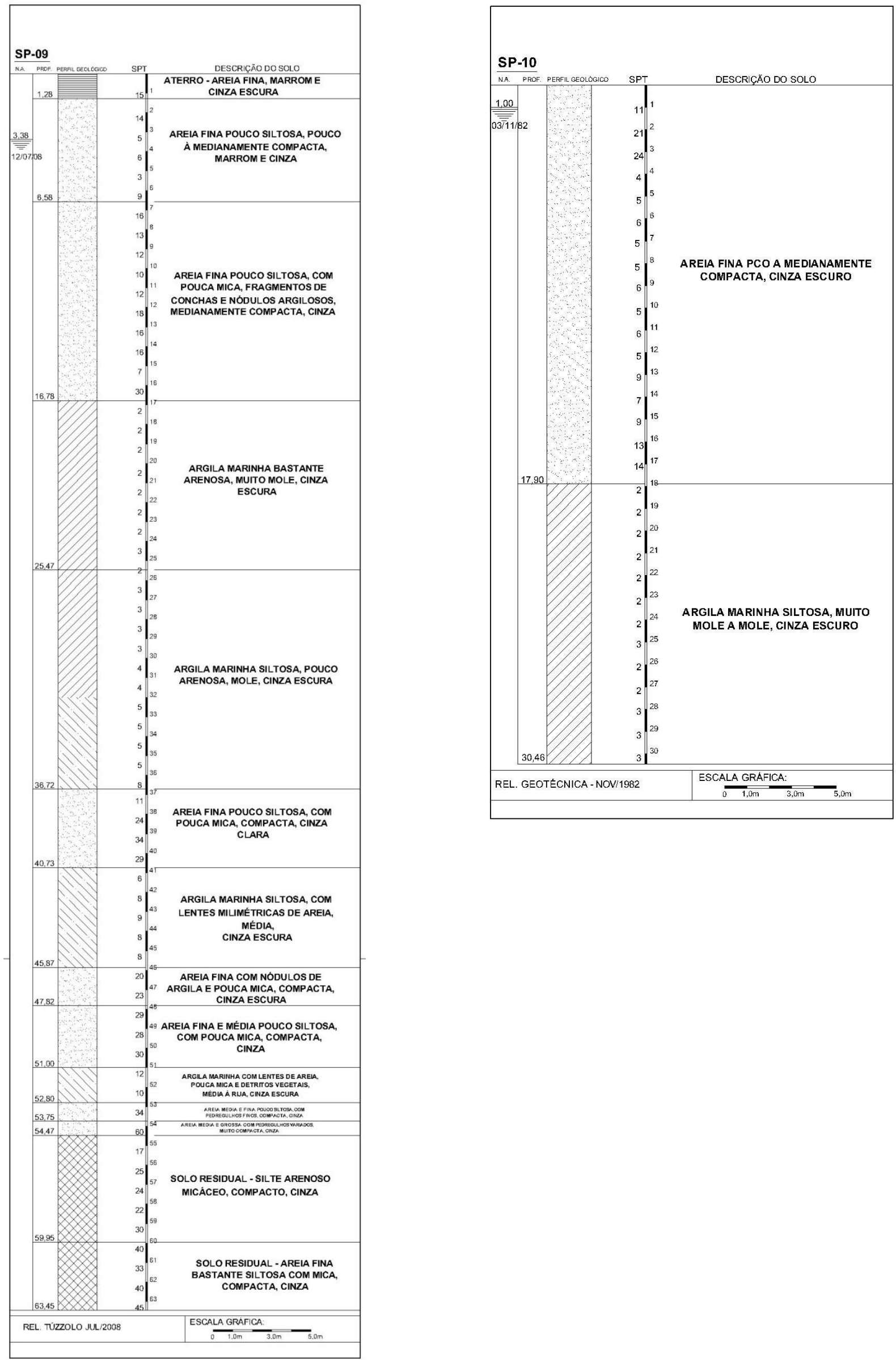

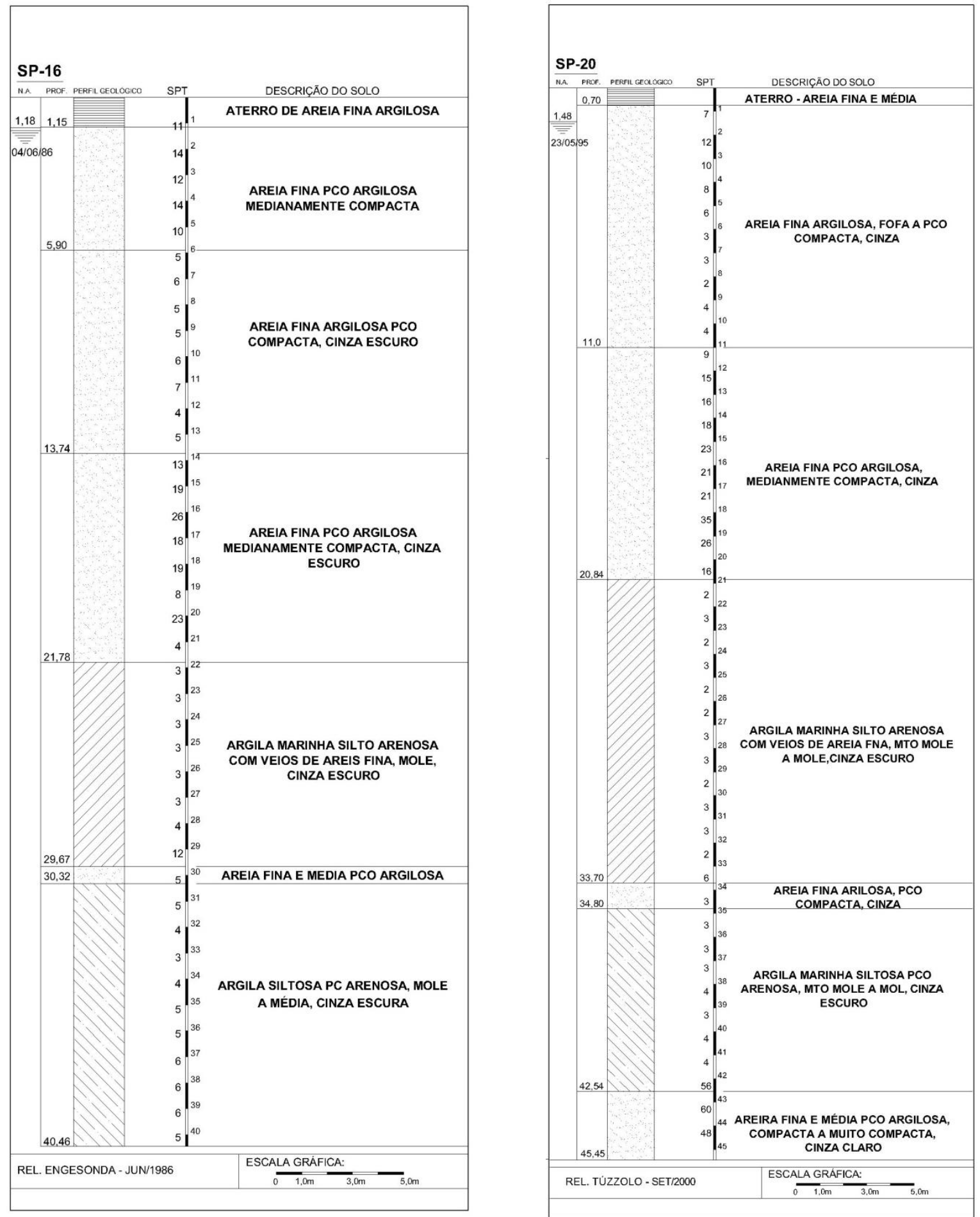

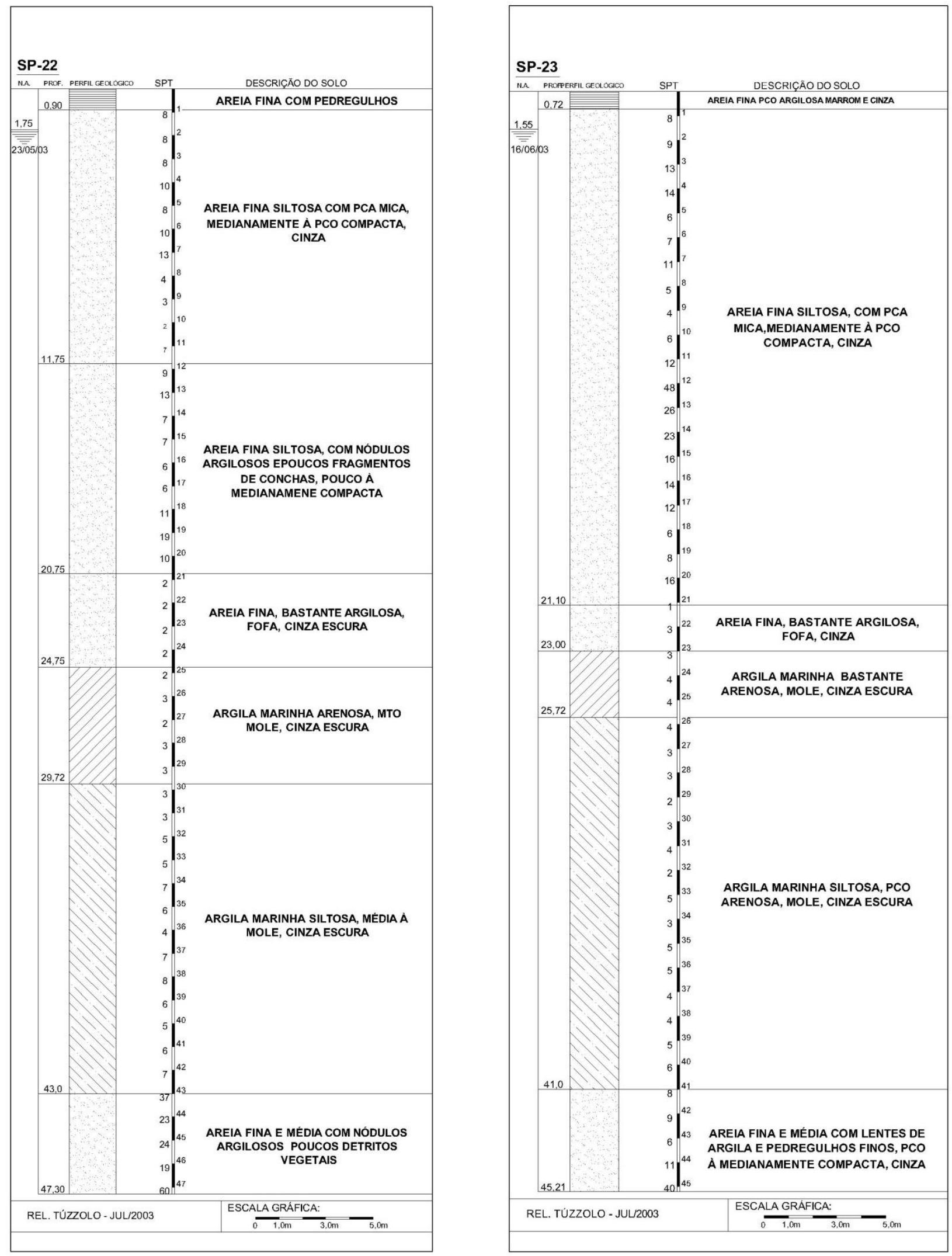

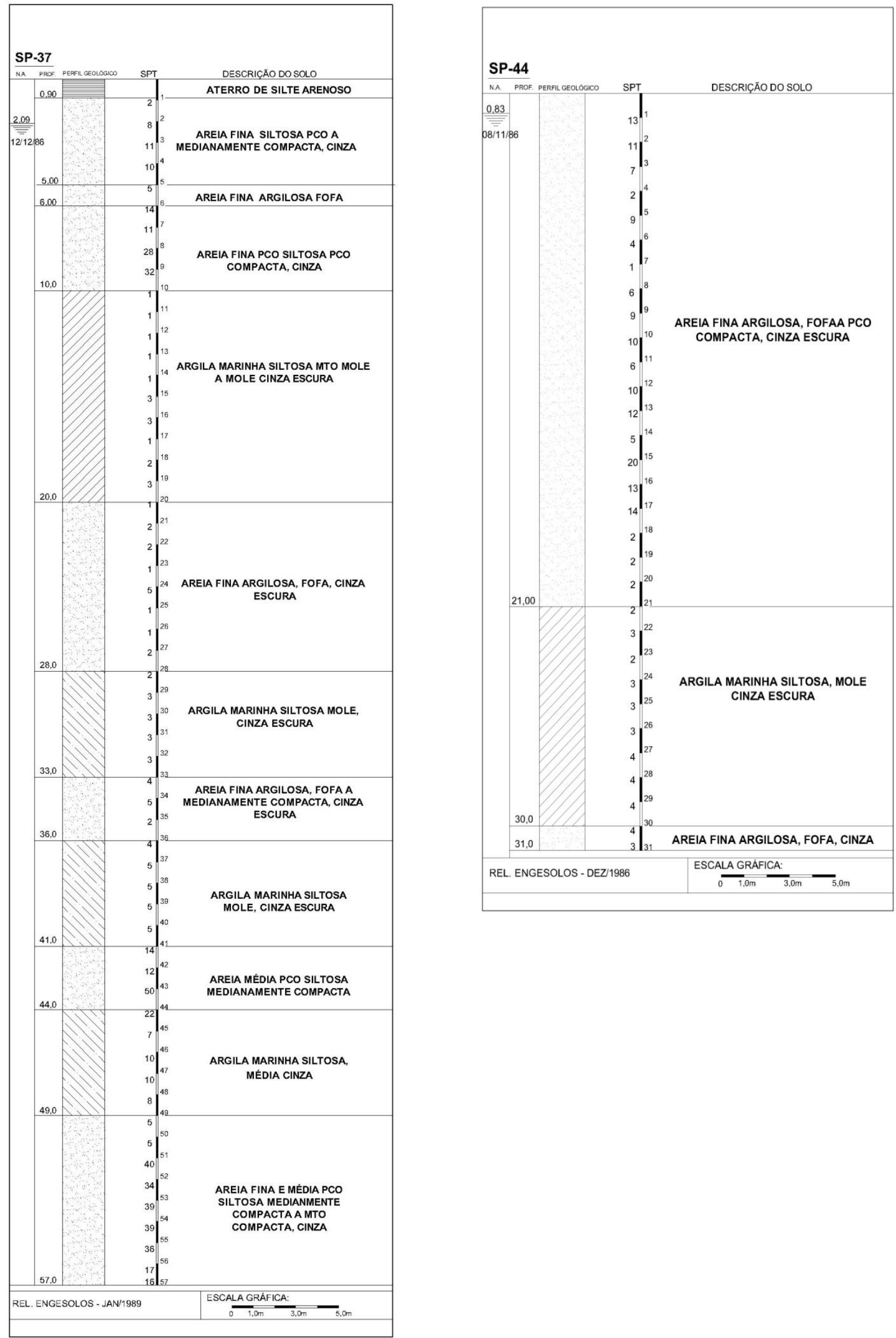

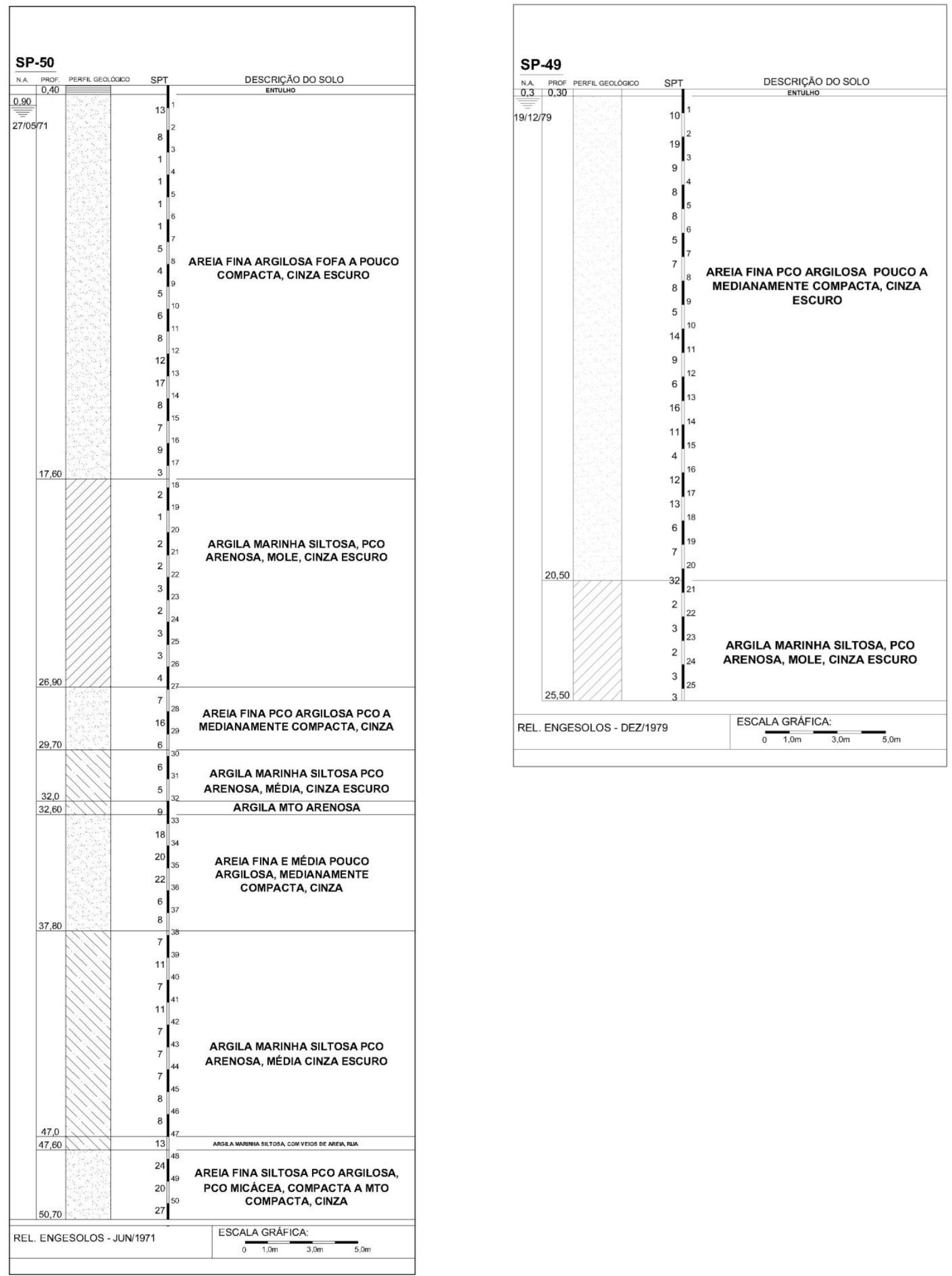
130
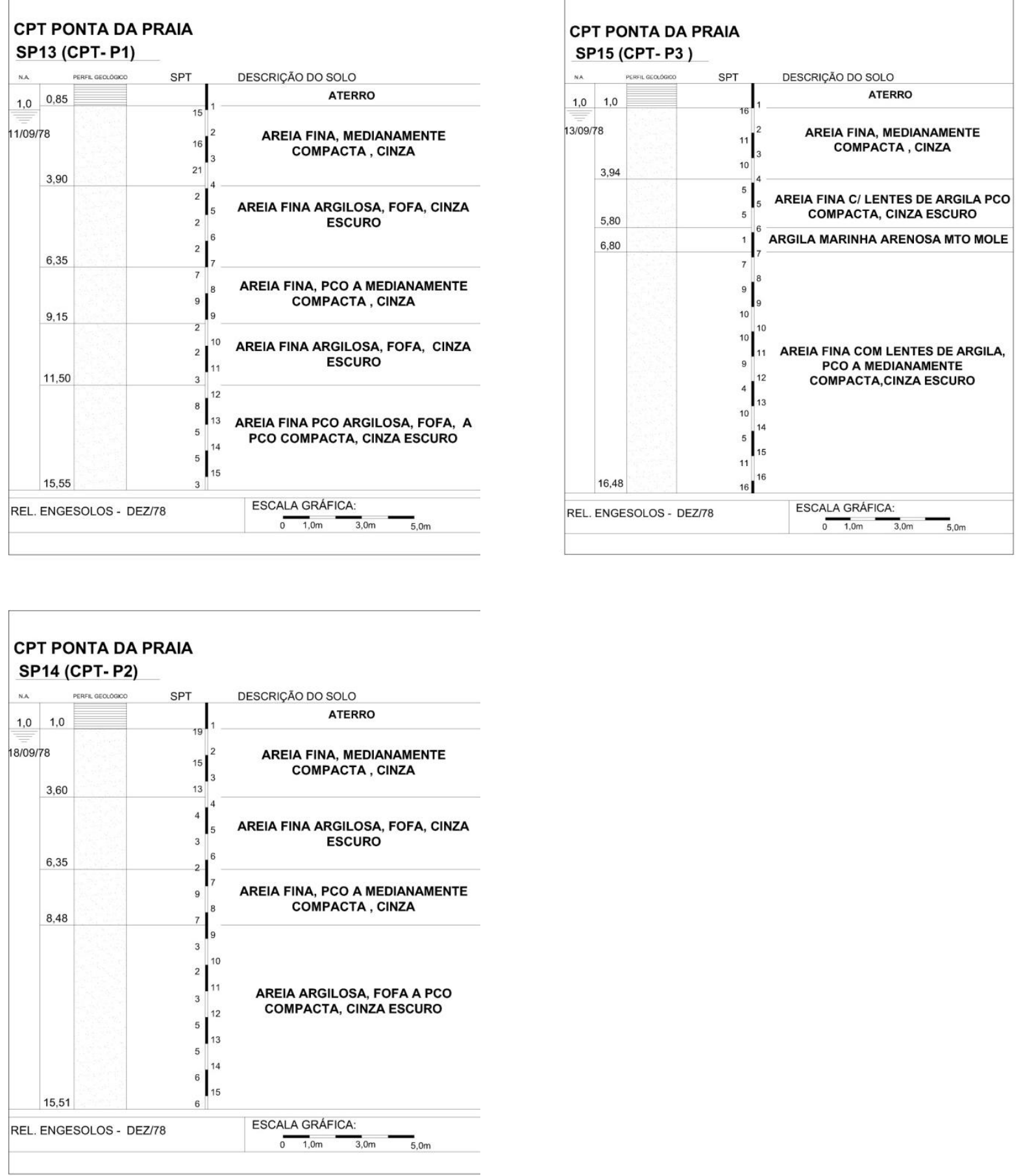


\section{ANEXO E - SONDAGENS DE REFERÊNCIA SEÇÕES \\ TRANSVERSAIS (Praia - Centro)}



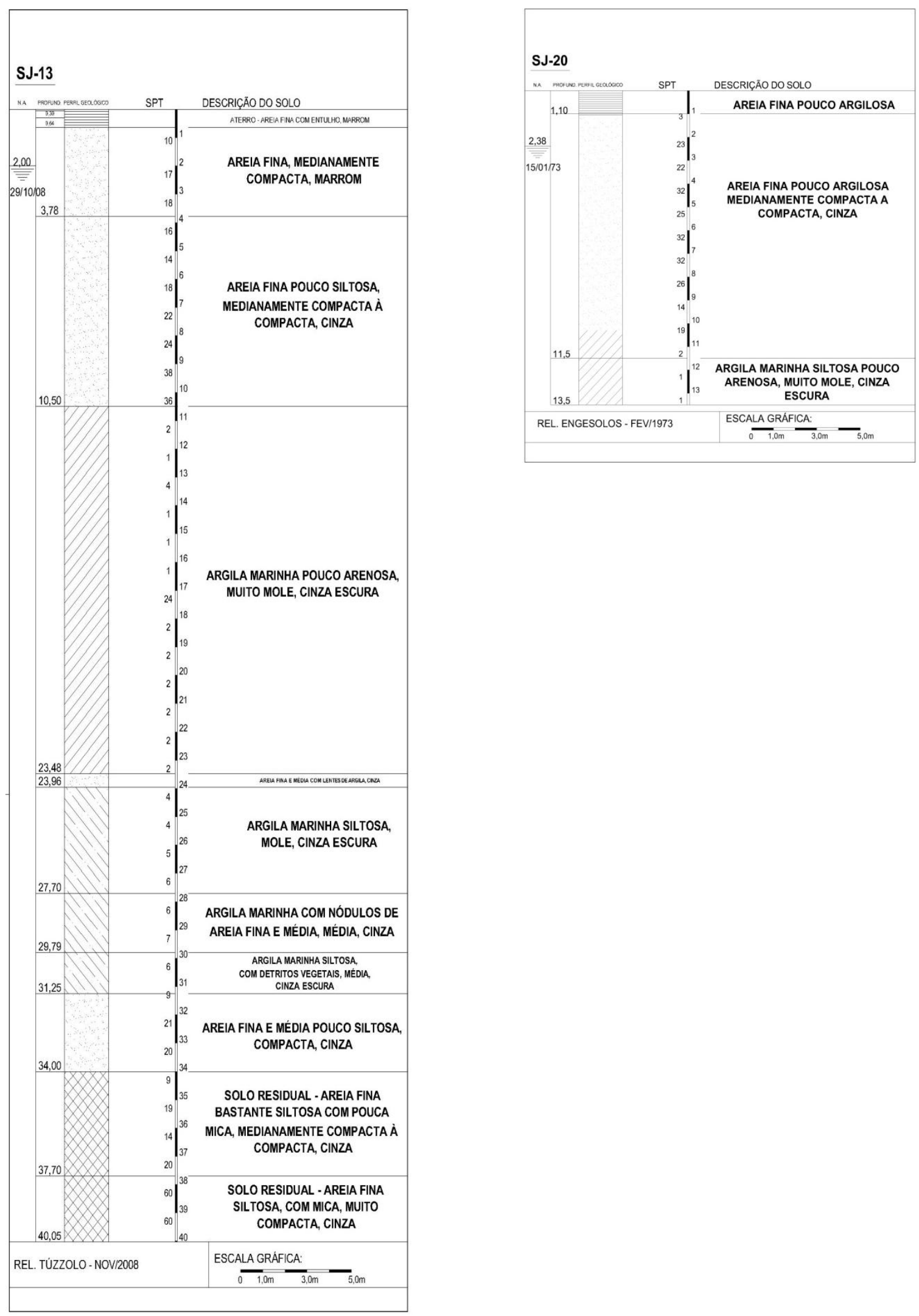

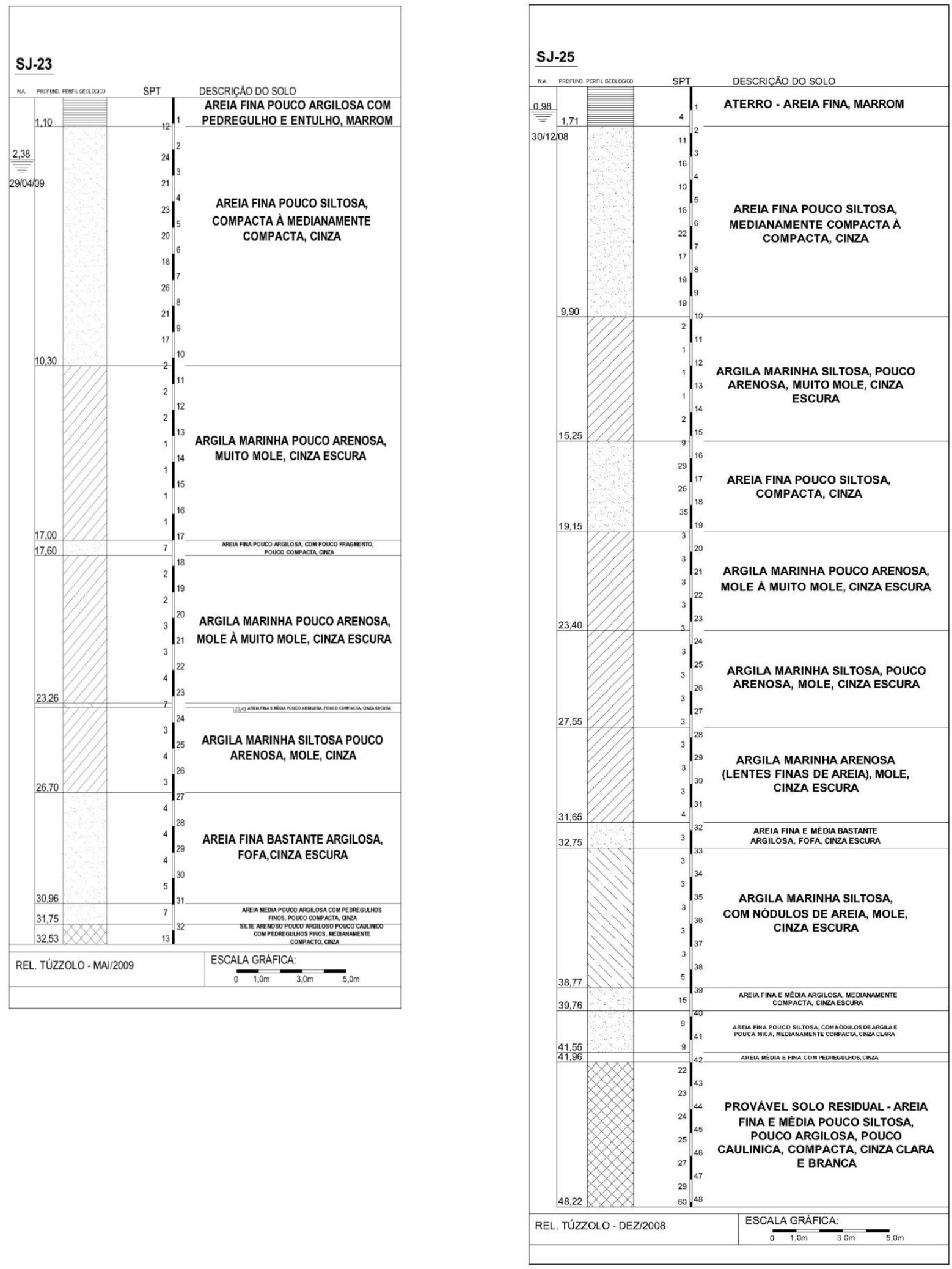

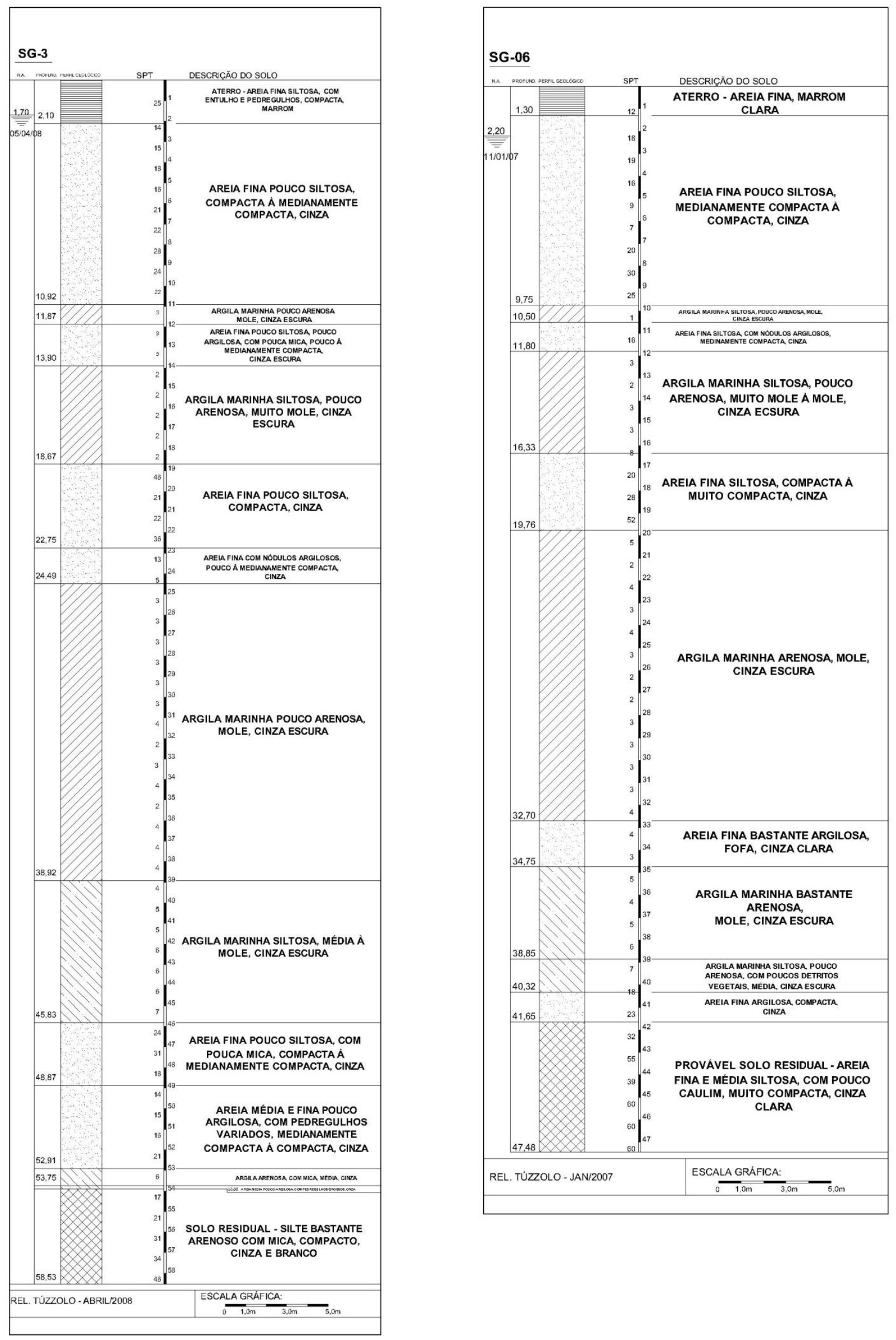

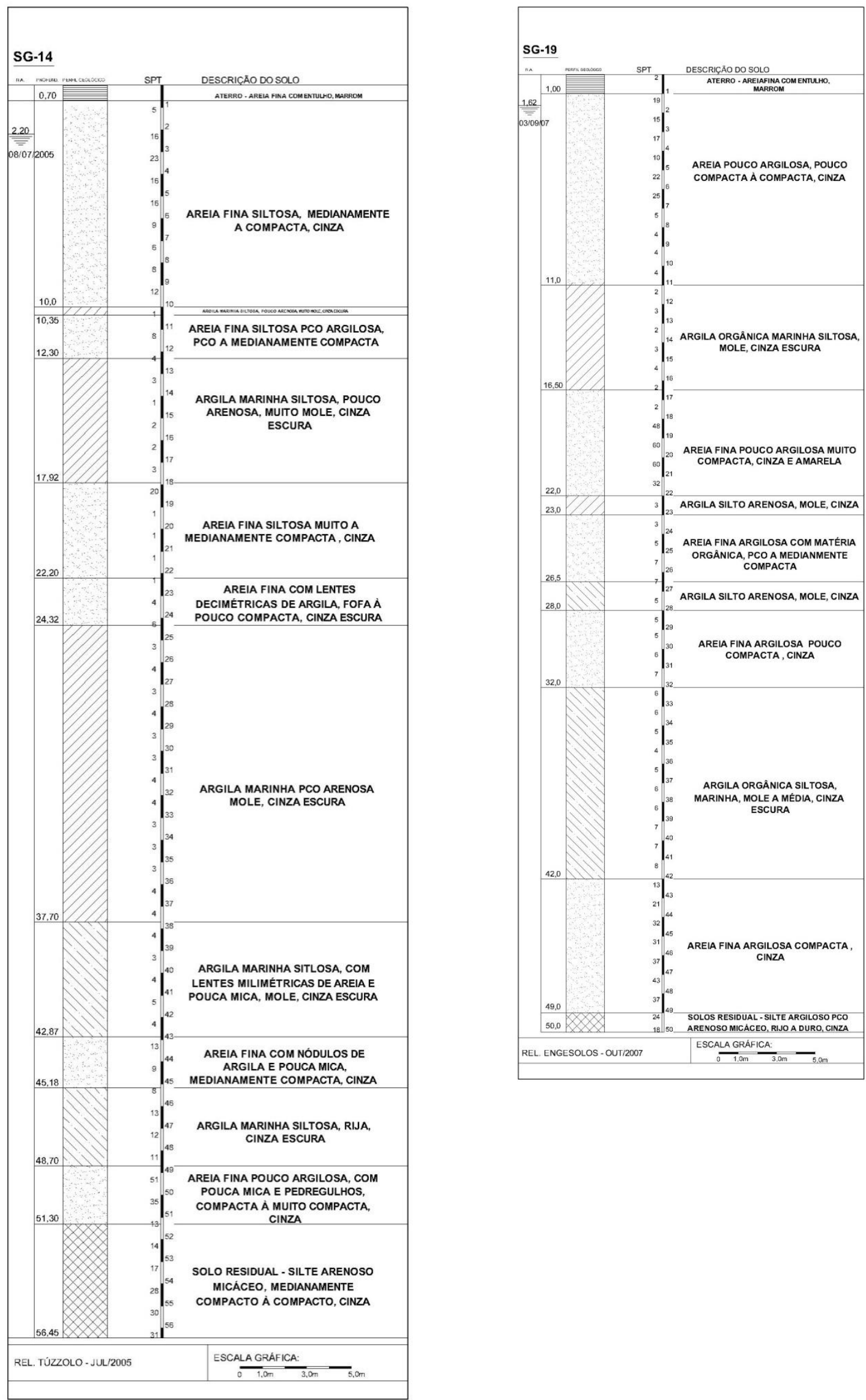

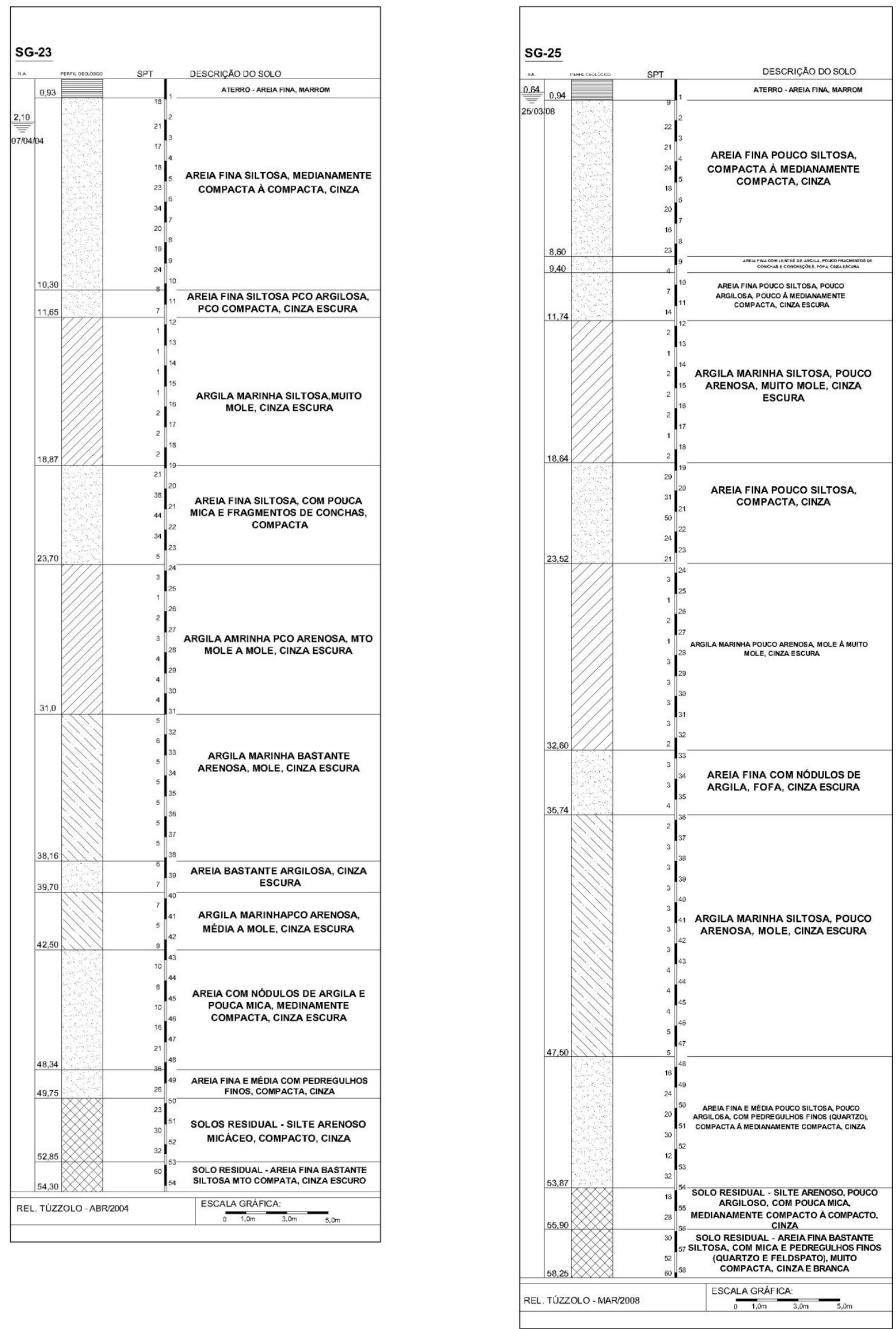

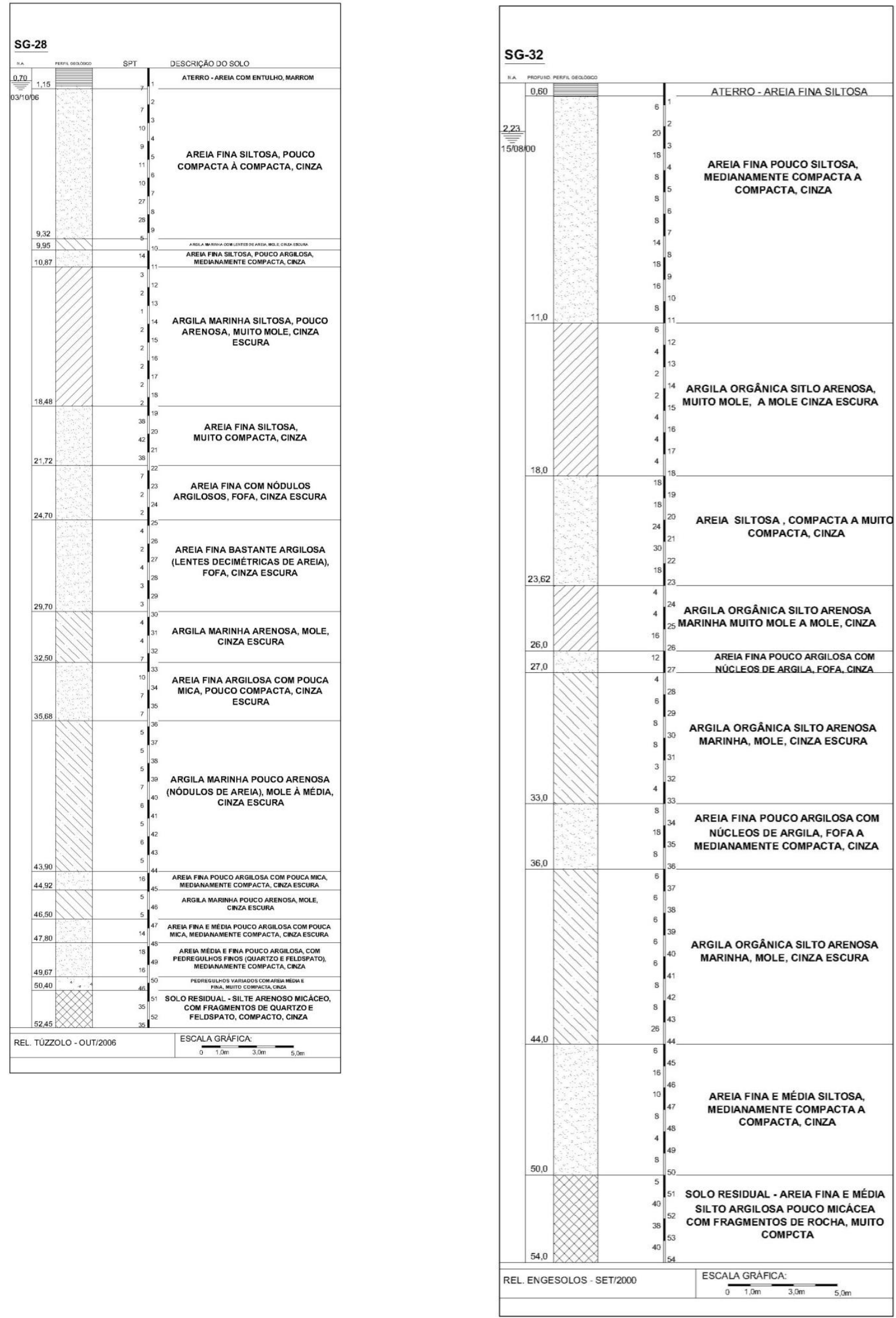

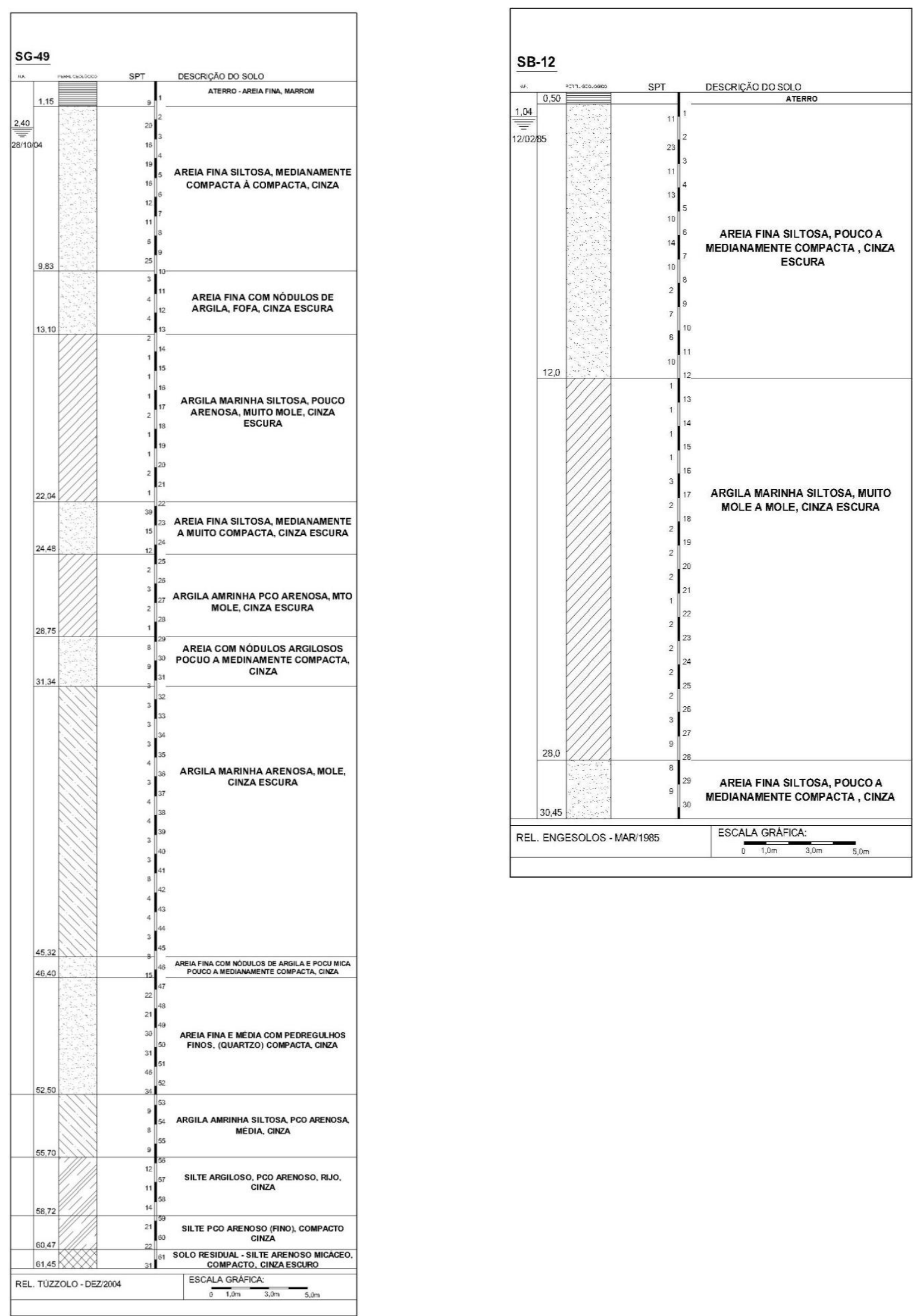

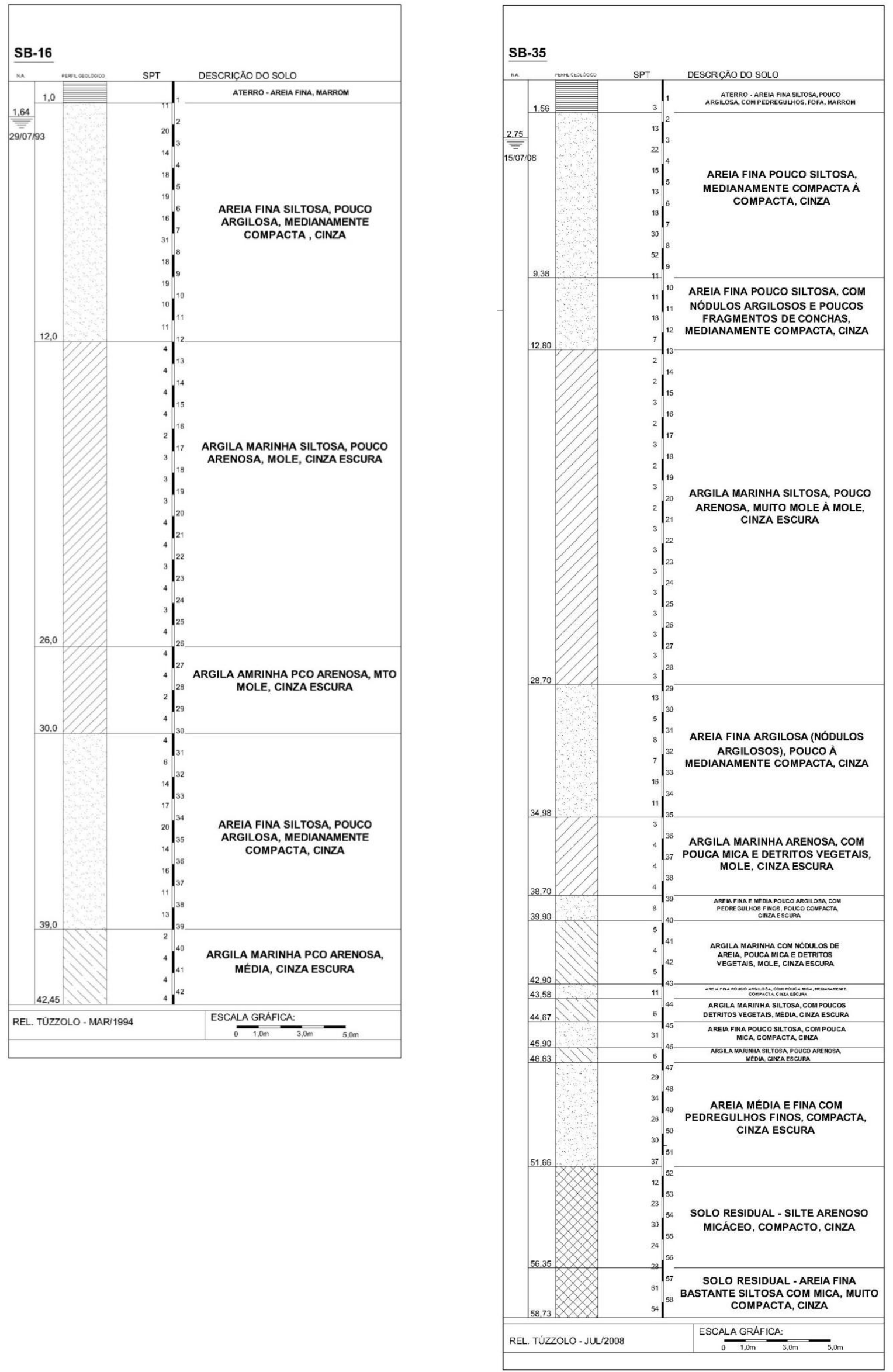

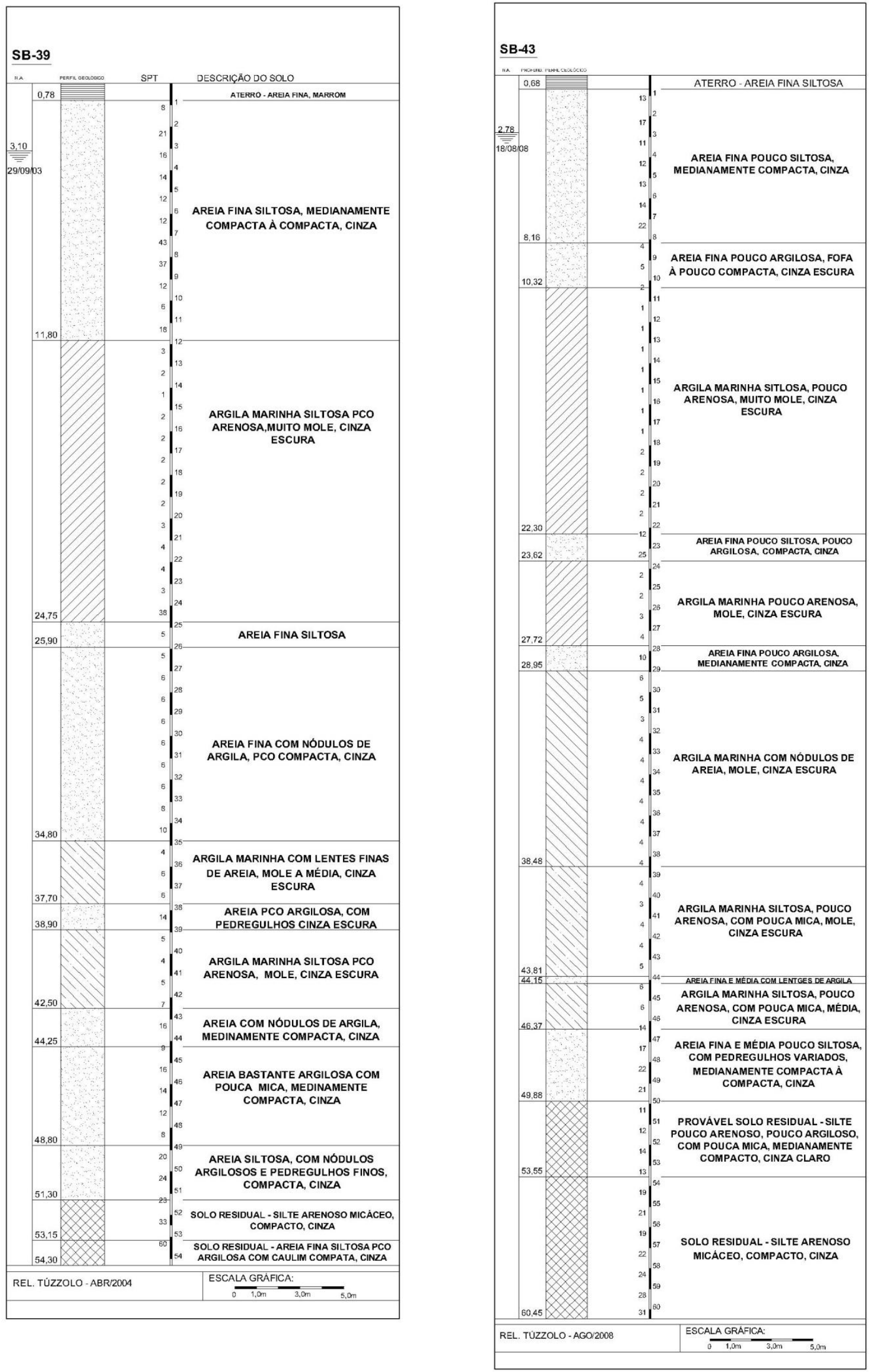

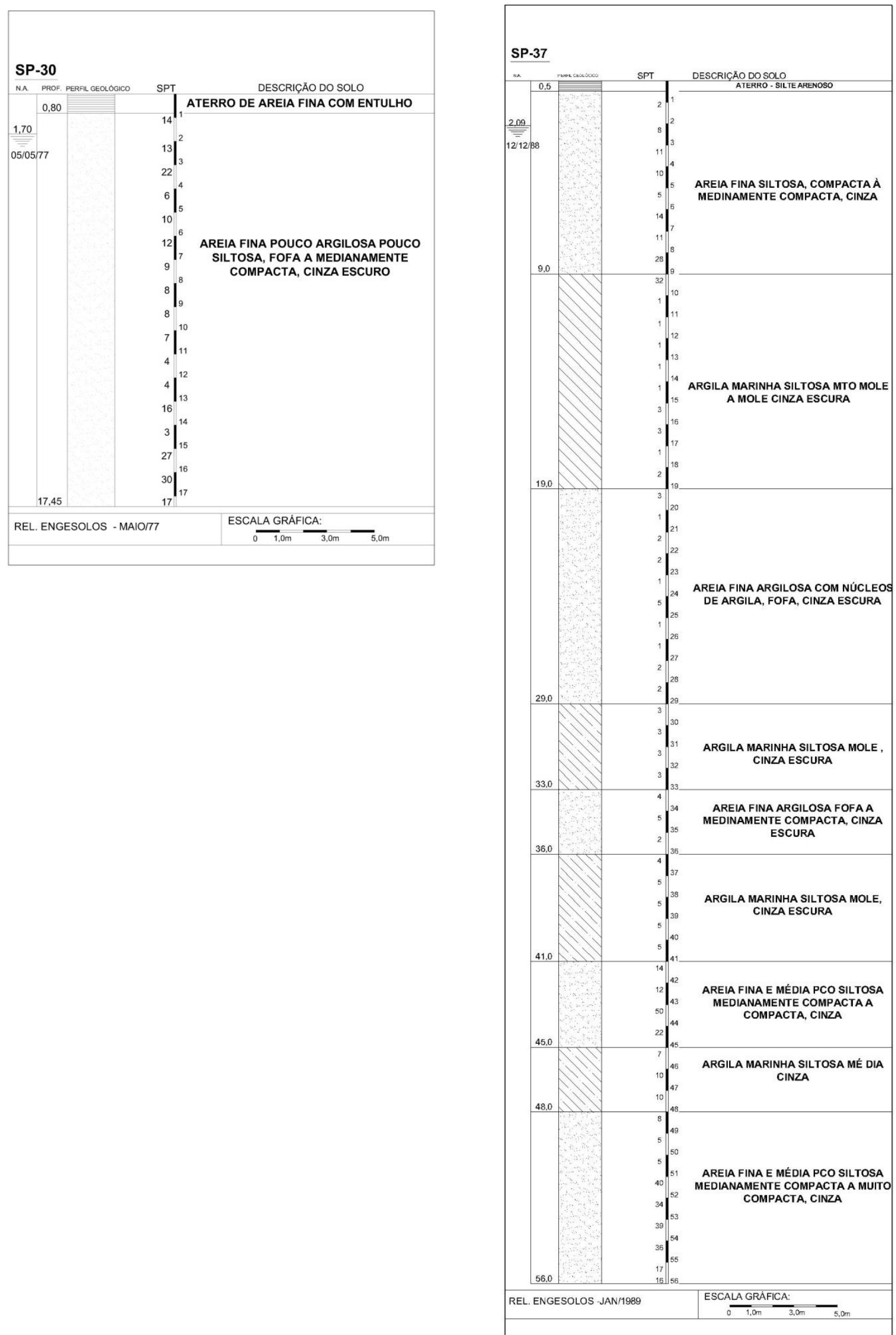

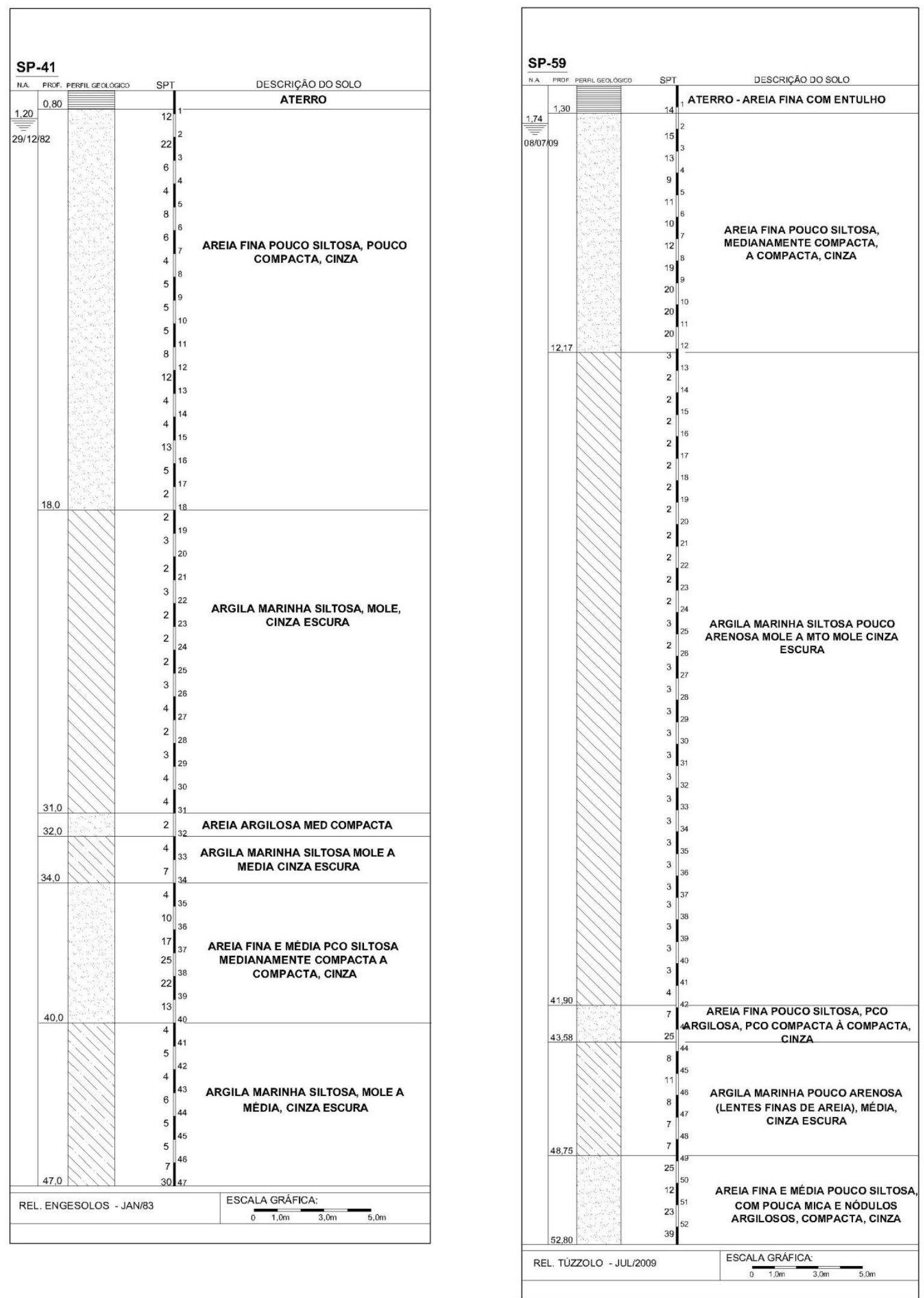

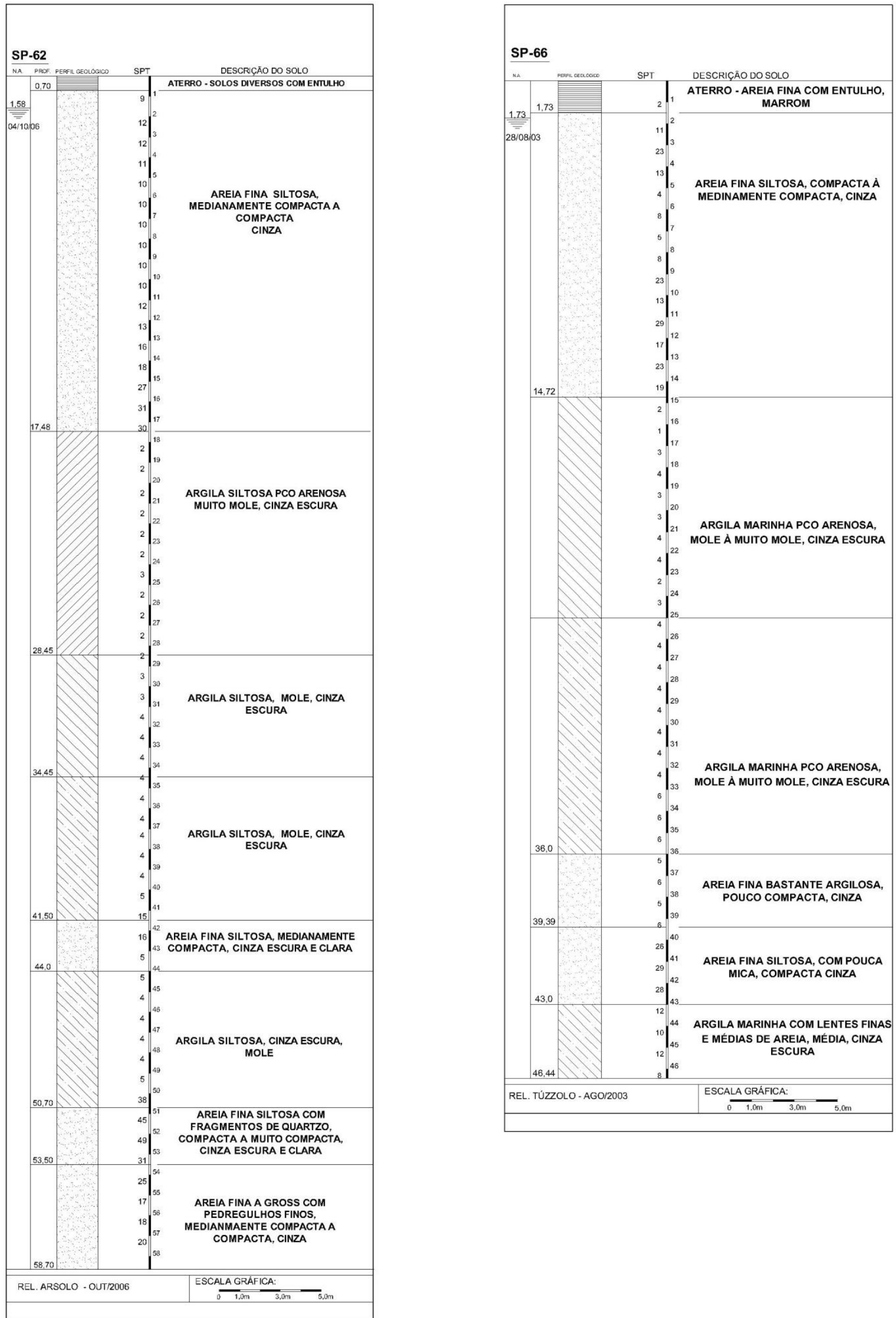


\section{BIBLIOGRAFIA}

AB' SABER, A.N. Litoral do Brasil. Ed. Metalivros. São Paulo, 2005

AOKI, Nelson e Velloso, D. Na Aproximate Method to Estimate the Bearing Capacity of Piles. In: V PASCSMFE. Buenos Aires, 1975

ARAÚJO FILHO, J.R. A Expansão Urbana de Santos. A Baixada Santista Aspectos geográfico. EDUSP. São Paulo, 1964. vol.3.

BJERRUM, I. Engineering Geology of Norweian Normally Consolidated Marine Clays as Related to Settlement of Buildings. In: Geotechinique 18 (2). Jun, 1967.

CARDOSO, Denise S. Análise dos Recalques de Alguns Edifícios da Orla Marítima de Santos: Dissertação de mestrado apresentada à Escola Politécnica da USP Universidade de São Paulo. São Paulo, 2002.

GERBER Inácio; GOLOMBEK Sigmundo; COLOTTO Armando S.A. Estabilização de recalques e tentativa de endireitamento de prédio 18 pavimentos em Santos. In: Congresso Panamericano de Mecânica de Suelos Y Cimentaciones. Buenos Aires, 1975. Anais. vol3.

DICIONÁRIO.PRO. Disponível em: http://www.dicionario.pro.br/dicionario/. Acesso em outubro. De 2008

GEOCITIES. Disponível em: http://br.geocities.com/guaruja_1/. Acesso em fevereiro de 2008

GONÇALVES, Heloisa.H; OLIVEIRA, Nilene.J. Parametro Geotécnicos das Argilas de Santos. In: XII Cobranseg, 2002. Anais. vol

GONÇALVES, Heloisa.H; OLIVEIRA, Nilene.J. O Edifício da Universidade Santa Cecília: Medidas de Recalque desde o Início da Obra . In: Worshop Passado Presente e Futuro dos Edifícios da Orla Marítima de Santos. Santos, 2003 
GONÇALVES, Heloísa. H. Santos' Inclined Buildings. In: RevistaSaint Petersburg Rússia, 2004. n.9:132-155

GONÇALVES, Heloísa H.S. Comportamento das Argilas moles: Aplicações a Problemas práticos da Engenharia Civil. Tese de Livre Docência apresentada à Escola Politécnica da USP - Universidade de São Paulo. São Paulo, 2005.

GONÇALVES, Heloísa. H. Histórias e Lendas de Santos: Prédios inclinam mais que Pisa. Disponível em http:// www.novomilenio.inf.com.br. Acesso em jan.2008.

FALCONI, Frederico; AZEM, Fábio; Hachich, Waldemar. Proposta de Renivelamento de Prédio em Santos. In: Workshop Passado Presente e Futuro dos Edifícios da Orla Marítima de Santos. Santos, 2003.

JAMIOLKOWSKI, Michele. B. The leaning Tower of Pisa. In: 15 th International Conference on Soil Mechanics and Geotechnical Engineering. Istanbul, 2000. Anais. vol4.

Maffei, Carlos. E. M; Gonçalves, H. H; Pimenta, P. M. The Plumnbing of 2,2o Inclined Tall Building. In: $15^{\text {th }}$ International Conference on Soil Mechanics and Geotechnical Engineering. Instanbul, 2000. Anais. vol 3.

MAFFEI, Carlos.E.M; GONÇALVES, Heloísa H.S; PIMENTA, Paulo. M. Renivelamento do Edifício Núncio Malzone: Projeto e Aspectos Estruturais. In: Worshop. Passado Presente e Futuro dos Edifícios da Orla Marítima de Santos. Santos, 2003

MASSAD, Faiçal. As Argilas Quartenárias da Baixada Santista: Características e Propriedades Geotécnicas.Tese de Livre Docência apresentada à Escola Politécnica da USP - Universidade de São Paulo. São Paulo, 1985.

MASSAD, Faiçal. Reinterpretação de Sondagens de Simples Reconhecimento da Baixada Santista, à Luz dos Novos Conhecimentos sobre a origem Geológica dos Sedimentos Quaternários.In: VIII Congresso Brasileiro de Mecânica dos Solos e Engenharia de Fundações. Porto Alegre, 1986b. Anais. vol 2. 
MASSAD, Faiçal. O Sobreadensamento das Argilas Quaternárias da Baixada Santista. In: VIII Congresso Brasileiro de Mecânica dos Solos e Engenharia de Fundações. Porto Alegre, 1986 c. Anais. vol2.

MASSAD, Faiçal. As Argilas Transicionais (Pleistocênicas) do Litoral Paulista: Características Geotécnicas e Propriedades de Engenharia. In: VIII Congresso Brasileiro de Mecânica dos Solos e Engenharia de Fundações. Porto Alegre, 1986. Anais. vol2

MASSAD, Faiçal. História Geológica e Propriedades dos Solos das Baixadas: Comparação entre Diferentes Locais ao Longo da Costa Brasileira. In: Simpósio sobre Depósitos Quartenários das Baixadas Litorâneas Brasileiras. Rio de Janeiro, 1988 a. Anais. vol1.

MASSAD, Faiçal. Propriedades dos Sedimentos Marinhos. In: Solos do Litoral de São Paulo. livro editado pela ABMS. São Paulo, 1994.

MASSAD, Faiçal; PEREZ, Francisco.S. O Efeito Combinado das Oscilações Negativas do Nível do Mar e do Envelhecimento no Sobreadensamento das Argilas Marinhas Holôcenicas de Santos. In:Revista Solos e Rochas. Abril, 1997. vol 20(1).

MASSAD, Faiçal. Baixada Santista: Implicações da História Geológica no projeto de Fundações. In: Revista Solos e Rochas. Abril, 1999. vol 22(1).

MASSAD, Faiçal. Características Geológicas e Geotécnicas dos Solos da Baixada Santista com ênfase na Cidade de Santos. In: Worshop Passado Presente e Futuro dos Edifícios da Orla Marítima de Santos. Santos, 2003

MASSAD, Faiçal. A Ação de Dunas nas Argilas Marinha e os Edifícios Inclinados de Santos. In: V Seminário de Engenharia de Fundações Especiais e Geotecnia. São Paulo, nov. 2004.

MASSAD,Faiçal. Sobre o Uso de ensaios de Piezocone no Aprofundamento dos Conhecimentos das Argilas Marinhas de Santos, Brazil. In:9 Congresso Nacional de Geotecnia. Aveiro, Portugal, 2004. Anais. vol1 
MASSAD, Faiçal. Os edifícios de Santos e a História Geológica Recente da Baixada Santista. In: V Geosul. Porto Alegre, 2006. Anais. vol1

MASSAD, Faiçal. Cidade de Santos, Brasil: Os Recalques dos Edifícios e o Sobreadensamento Errático dos Solos Moles. In: Congresso Luso Brasileiro de Geotecnia. Coimbra, 2008-a.

MASSAD, Faiçal. Os edifícios de Santos e a História Geológica Recente da Baixada Santista. In: V Geosul. Porto Alegre, 2008-b. Anais. vol1.

MASSAD, Faiçal. Solos Marinhos da Baixada Santista características e propriedades geotécnicas. Oficina de textos.São Paulo, 2009

MACHADO, José. Estudos de Recalques de Fundações Diretas em Santos. In: I Congresso Basileiro de Mecânica dos Solos e Engenharia de Fundações. Porto Alegre, 1954. Anias. vol2

MACHADO,José. Estudo Comparativo de Recalques Calculados e Observados em Fundações Diretas em Santos. In: II Congresso Brasileiro de Mecanica dos Solos e Engenharia de Fundações. Recife e Campina Grande, 1958. Anais. vol1.

MENDES, Carlos. P. História do porto: No tempo dos trapiches. Disponível em: http://www.novomilenio.inf.com.br. Acesso em nov. 2008

MONDIN, Leda. Histórias e Lendas de Santos: Ponta da Praia um Bairro de Contrastes. Disponível em: http://www.novomilenio.inf.com.br. Acesso em nov. 2008 NOVO MILENIO. Disponível em: http:// www.novomilenio.inf.br. Acesso em julho de 2008.

NUNES, Luis Antônio. P. Edifícios Inclinados de Santos Aspectos Sociais e Urbanísticos. In: Worshop Passado Presente e Futuro dos Edifícios da Orla Marítima de Santos. Santos, nov. 2003. 
OLIVEIRA, Nilene. J. Estudo Comparativo de Recalques observados e Calculados utilizando a Teoria de Terzaghi: O caso de um edifico situado em Santos. Dissertação de mestrado apresentada à Escola Politécnica da USP - Universidade de São Paulo. São Paulo, 2000.

PETRONE, Pasquale. Povoamento e população. A Baixada Santista Aspéctos Geográficos. EDUSP. São Paulo, 1964. vol2.

PROJETO ORLA, Programa Piloto. SEIXAS, Nilene J.O; DAMIN, Orlando C.B; SANTOS, Laureana O; GOMES, Leonardo F; PINHEIROS MATEUS, Marcelo; Dias, Marianna S; Projeto não publicado pela Prefeitura Municipal de Santos. Santos, 2004

RANZINE, Stelvio. M.T. Stabilization of leaning structures: The Tower os Pisa case. In: Géotechnique, 2001. v.51, n.7.

RANZINI Stelvio M.T. Estabilização de Edifícios Inclinados: Nova Abordagem (com vistas aos casos de baixadas litorâneas).In: Worshop Passado Presente e Futuro dos Edifícios da Orla Marítima de Santos.Santos, 2003

RODRIGUES, José C. As Bases Geológicas. A Baixada Santista Aspectos Geográficos. EDUSP. São Paulo, 1964. vol1.

SANGLERAT, G. The Penetrometer and Soil Exploration Interpretation of Penetration Diagrams Theory and Practice. In: Elsevier Publishing Company. Amsterdam ondon New York, 1972

SANTOYO Enrique V; SHELLEY Efraim O. Cement Injection in Mexico City for Leveling Buldings. In: Worshop Passado Presente e Futuro dos Edifícios da Orla Marítima de Santos. Santos, 2003

SCHNAID, Fernando. Ensaios de Campo e suas aplicações à Engenharia de Fundações. Oficina de textos. São Paulo, 2000 
SUGUIO, Kenitio; MARTIN. Louis. Formações Quaternárias Marinhas do Litoral Paulista e Sul Fluminence. Publicação Especial no 1: Quaternary Marine Formation of the State of São Paulo and Sourthern Rio de Janeiro In: International Symposium on Coastal Evolution in the Quaternary. São Paulo, 1978

SUGUIO, Kenitio; MARTIN. Louis. Progress in Research on Quaternary Sea Level Changes and Coastal Evolution in Brazil, Preprint: variations in sea level in the last 15,000 years, Magnitude and causes . Univ. South Caroline, USA,1981

SUGUIO, Kenitiro; MARTIN. Louis. Geologia do Quartenário. In: Solos do Litoral de São Paulo. livro editado pela ABMS. São Paulo, 1994

SUGUIO, Kenitiro. Avaliação da Dinâmica Sedimentar no Litoral Brasileiro em Diferentes Escalas Temporais. Aula Inaugural de 1996. São Carlos.1996

TEIXEIRA, Alberto H. Caso de um edifico em que la Camada de Arcilla (Santos) se Encontraba Inusitadamente Preconsolidada. In: Congresso Panamericano de Suelos Y Cimentaciones. México, 1960-a. Anais. vol1

TEIXEIRA, Alberto H. Condicione Típicas del Subsuelo Y Problemas de Asiento em Santos, Barasil. In: Congresso Panamericano de Mecanica de Suelos $Y$ Cimentaciones. México,1960-b. Anais. vol1.

TEIXEIRA, Alberto H.- Fundações Rasas na Baixada Santista. In: Solos do Litoral de São Paulo. livro editado pela ABMS. São Paulo, 1994.

VARGAS, Milton. Fundação em Santos é Problema: Recalque é Questão de Temperamento. Evento I.E de São Paulo. O Dirigente Construtor 2. São Paulo, 1965.

VARGAS, Milton. Historia dos Conhecimentos Geotécnicos: Serra do Mar. In: Solos do Litoral de São Paulo. Livro editado pela ABMS. São Paulo, 1994.

VELLOSO, D. Capacidade de carga por meio do SPT. In: SEFE II. São Paulo, 1991. Anais vol 2. 
WIKIPÉDIA. Disponível em: http:// www.wikipedia.org/wiki/Santos. Acesso em fevereiro.de 2008

\section{BIBLIOGRAFIA COMPLEMENTAR}

CINTRA, José Carlos. A. Didática e Oratória com Data-Show. Ed. Compacta. São Carlos. São Paulo, 2008

GOOGLEEARTH. Disponível em: http:// www.Googleearth.com. Acesso em janeiro de 2008, março de 2009

GOOGLE MAPS BRASIL. Disponível em: http://maps.google.com.br. Acesso em maio de 2009

MANUAL DE ESTILO EDITOR ABRIL: Um manual prático de redação para jornalistas, escritores, editores, estudantes e profissionais ou amadores $3^{\circ}$ edição editora Nova Fronteira

SEVERINO, Antonio J. Metodologia do Trabalho Científico. 23 edicão. Editora Cortez.

SOUSA PINTO, Carlos. Curso Básico de Mecânica dos Solos. Oficina de textos 2 edição. São Paulo, 2002

VIVA SANTOS. Disponível em: http:// www.vivasantos.com.br. Acesso em janeiro de 2008 